UNIVERSIDADE DE SÃO PAULO

INSTITUTO DE PSICOLOGIA

ALINE MOREIRA DA SILVA TAFNER

OFICINA EXPRESSIVA DE DESENHO E PINTURA COM CRIANÇAS E ADOLESCENTES ABRIGADOS E SEU CUIDADOR

SÃO PAULO

2013 


\section{ALINE MOREIRA DA SILVA TAFNER}

\section{OFICINA EXPRESSIVA DE DESENHO E PINTURA COM CRIANÇAS E ADOLESCENTES ABRIGADOS E SEU CUIDADOR}

Dissertação apresentada ao Instituto de Psicologia da Universidade de São Paulo para obtenção do título de Mestre em Psicologia.

Área de concentração: Psicologia Clínica

Orientadora: Profa . Drà. Leila Salomão de La Plata Cury Tardivo

SÃO PAULO

2013 
AUTORIZO A REPRODUÇÃO E DIVULGAÇÃO TOTAL OU PARCIAL DESTE TRABALHO, POR QUALQUER MEIO CONVENCIONAL OU ELETRÔNICO, PARA FINS DE ESTUDO E PESQUISA, DESDE QUE CITADA A FONTE.

Catalogação na publicação

Biblioteca Dante Moreira Leite

Instituto de Psicologia da Universidade de São Paulo

Tafner, Aline Moreira da Silva.

Oficina Expressiva de Desenho e Pintura com crianças e adolescentes abrigados e seu cuidados / Aline Moreira da Silva Tafner; orientadora Leila Salomão de La Plata Cury Tardivo. -- São Paulo, 2013.

$251 \mathrm{f}$.

Dissertação (Mestrado - Programa de Pós-Graduação em Psicologia. Área de Concentração: Psicologia Clinica) - Instituto de Psicologia da Universidade de São Paulo.

1. Crianças abrigadas 2. Psicodiagnóstico 3. Enquadre diferenciado I. Título. 
Nome: Tafner, Aline Moreira da Silva

Título: Oficina expressiva de desenho e pintura com crianças e adolescentes abrigados e seu cuidados.

Dissertação apresentada ao Instituto de Psicologia da Universidade de São Paulo para obtenção do título de Mestre em Psicologia.

Dissertação defendida e aprovada em:

BANCA EXAMINADORA:

Prof. Dr.

Julgamento:

Prof. Dr.

Julgamento:

Prof. Dr.

Julgamento:
Instituição:

Assinatura:

Instituição:

Assinatura:

Instituição:

Assinatura: 
Às crianças e aos adolescentes que já iniciam a vida ultrapassando grandes obstáculos. 


\section{AGRADECIMENTOS}

À minha orientadora, Prof ${ }^{\mathrm{a}} \mathrm{Dr}^{\mathrm{a}}$ Leila Salomão de La Plata Cury Tardivo por todo incentivo, dedicação e generosidade.

Ao Antonio Augusto Pinto Júnior e à Claudia Aranha Gil pelas contribuições e sugestões dadas no exame de qualificação.

A todos os membros da banca examinadora pela disponibilidade, atenção e discussão deste estudo.

À coordenação, funcionários e equipe técnica do abrigo municipal onde foi realizado este trabalho, pela cordialidade e receptividade.

À Maria Aparecida Mazzante Colaccico pelo carinho, simpatia e seriedade.

A todas as colegas do grupo de atendimento a crianças e adolescentes vítimas de violência do APOIAR, pelo compartilhamento das esperanças e sofrimentos que emergem nesta clínica.

Aos funcionários do Instituto de Psicologia da Universidade de São Paulo, em especial à Claudia, Cícera, Ana Maria e Moisés, por todo auxílio prestado. Aos amigos e familiares que acompanharam esta empreitada árdua.

À Yara Sayão que generosamente me acompanhou nos primeiros passos junto das crianças e adolescentes abrigados.

À minha madrinha querida, por toda uma vida ao meu lado.

Ao meu pai pelo incentivo inesgotável.

À minha mãe por toda doação e sacrifícios.

Aos meus irmãos, Juliana e Rodrigo, pela confiança e amor.

Ao meu querido André por estar sempre ao meu lado com suas palavras doces e carinho.

A todas as crianças e adolescentes abrigados que cruzaram o meu caminho, pela força e obstinação que demonstraram diante das dificuldades. 


\section{RESUMO}

Tafner, A.M.S. Oficina expressiva de desenho e pintura com crianças e adolescentes abrigados e seu cuidados. 2013. 251p. Dissertação (Mestrado) Instituto de Psicologia da Universidade de São Paulo, São Paulo, 2013.

A pesquisa teve um duplo objetivo: (1) realizar um estudo clínico, a partir: de psicodiagnósticos compreensivos de crianças e adolescentes abrigados, suas relações dentro do abrigo e perspectivas de vida; (2) desenvolver e apresentar uma Oficina Terapêutica, a Oficina de Desenho e Pintura, como modalidade psicoterapêutica, em enquadre grupal, e verificar seu alcance neste grupo. A pesquisa se desenvolveu a partir do método clínico, de referencial psicanalítico, sob os aportes de Winnicott. Três meninas abrigadas, de 10, 14 e 16 anos; e seu cuidador participaram de todas as fases deste estudo. No entanto, houve a participação esporádica de outros 8 adolescentes (entre 13 e 18 anos) e 3 cuidadoras. Para a compreensão diagnóstica foram realizadas entrevistas individuais (com o cuidador e as três meninas), e o uso de instrumentos, exclusivamente com os jovens. Utilizou-se o Desenho da Figura Humana (DFH), Desenho da Pessoa na Chuva, Teste de Fábulas de Düss, Inventário de Frases no Diagnóstico de Violência Doméstica (IFVD) e Questionário de Depressão Infantil (CDI). Os dados obtidos nesta etapa inicial foram compreendidos em conjunto com o processo desencadeado pelos doze encontros que compuseram a Oficina. Ao final, foram realizadas entrevistas devolutivas para as crianças e a Diretora do abrigo e a reaplicação do Desenho da Pessoa na Chuva e do CDI nos jovens. Os vínculos afetivos surgiram como aspecto central na compreensão da vivência dessas crianças e adolescentes. $O$ estudo descreve estas etapas que compreenderam o processo e permitiram a emergência de aspectos mal integrados relacionados à vida dentro e fora do abrigo. $O$ enquadre ainda proporcionou a elaboração e integração do Self das crianças e adolescentes participantes. Dessa forma, a partir da análise do processo psicoterapêutico, a proposta da Oficina se mostrou eficaz, sendo relevante para contextos institucionais como esse onde o trabalho pôde se desenvolver.

Palavras Chave: Crianças abrigadas, psicodiagnóstico, enquadre diferenciado. 


\begin{abstract}
Tafner, A.M.S. Workshop of drawing and painting with sheltered children and teenagers and their caregiver. 2013. 251p. Dissertação (Mestrado) - Instituto de Psicologia, Universidade de São Paulo, São Paulo, 2013.
\end{abstract}

The research had two main aims: (1) conduct a clinical study - a psychodiagnosis comprehensive of sheltered children and adolescents and their relationships within the shelter and life prospects, (2) develop and submit a Therapeutic Workshop, the Workshop of Drawing and Painting as psychotherapeutic modality in group framework, and verify its reach to this group. The research was developed from the clinical method of psychoanalysis, based on the contributions of Winnicott. Three sheltered girls, 10, 14 and 16 years old, and their caregiver participated in all phases of this study. However, there were sporadic participation of eight other teenagers (between 13 and 18 years old) and 3 caregivers. To elaborated the diagnostic comprehension, single interviews were conducted (with the caregiver and the three girls), and the use of instruments exclusively with the girls. We used the Human Figure Drawing (HFD), the Person in the Rain Drawing, Duss' Fables Test, The Phrase Inventory of Intrafamilial Child Abuse (PIICA) and Children's Depression Inventory (CDI). The data obtained in this initial stage were understood in conjunction with the process including the twelve meetings that formed the Workshop. By the end, back interviews were performed for the children and the shelter's Director and the reapplication of Person in the Rain Drawing and CDI on the children. The emotional bonds emerged as a central aspect in understanding the experiences of these children and adolescents. The study describes these steps to understand the process and provided the emergence of poorly integrated aspects related to life inside and outside the shelter. The framework also provided the Self development and integration of children and adolescents participating. Thus, from the analysis of the psychotherapeutic process, the proposal of the workshop was effective and relevant to this institutional context.

Keywords: Sheltered Children, Psycodiagnosis, Nontraditional Framework. 


\section{LISTA DE TABELAS}

Tabela 1 Motivo do acolhimento institucional de crianças e adolescentes no Brasil 32

Tabela 2 Produções gráficas de Gabriela 89

Tabela 3 Respostas de Gabriela ao Teste das Fábulas... 90

Tabela 4 Pontuações de Gabriela no IFVD e CDI 90

Tabela 5 Produções gráficas de Maiara. 94

Tabela 6 Respostas de Maiara ao Teste das Fábulas................................... 94

Tabela 7 Pontuação de Maiara no IFVD e no CDI......................................... 95

Tabela 8 Produções Gráficas de Josi......................................................... 99

Tabela 9 Respostas de Josi ao Teste das Fábulas........................................ 99

Tabela 10 Pontuação de Josi no IFVD e CDI................................................... 100

Tabela 11 Presença de cada participante na Oficina...................................... 104

Tabela12 Desenho da Pessoa na Chuva -

primeira e segunda aplicação..................................................... 174

Tabela 13 Pontuação no CDI - Primeira e segunda aplicação.......................... 175 


\section{LISTA DE FIGURAS}

Figura 1 Desenho de Roberto no primeiro encontro....

Figura 2 Desenho de Josi no primeiro encontro

108

Figura 3 Desenho de Maiara no primeiro encontro

108

Figura 4

Desenho de Gabriela no primeiro encontro.

109

Figura 5

Desenho de Josi no segundo encontro

112

Figura 6

Desenho de Gabriela no segundo encontro.

112

Figura 7

Desenho de Roberto no segundo encontro.

113

Figura 8

Desenho de Maiara no segundo encontro

113

Figura 9 Desenho de Maiara no terceiro encontro

Figura 10 Desenho de Josi no terceiro encontro

Figura 11 Desenho de Josi no quarto encontro

Figura 12 Desenho de Maiara no quarto encontro.

Figura 13 Desenho de Gabriela no quarto encontro

Figura 14 Desenho 1 de Guilherme no quarto encontro

120

Figura 15 Desenho 2 de Guilherme no quarto encontro

Figura 16 Desenho de Roberto no quinto encontro

Figura 17 Desenho de Maiara no quinto encontro

Figura 18

Desenho de Josi no quinto encontro

Figura 19

Desenho 1 de Guilherme no quinto encontro

Figura 20 Desenho 2 de Guilherme no quinto encontro.

Figura 21 Desenho de Gabriela no quinto encontro

Figura 22 Desenho 1 de Lucas no sexto encontro

Figura 23 Desenho 2 de Lucas no sexto encontro

Figura 24 Desenho 1 de Gabriela no sexto encontro 
Figura 25 Desenho 2 de Gabriela no sexto encontro

Figura 26 Desenho da educadora Meire no sexto encontro

Figura 27 Desenho da educadora Cecília no sexto encontro

Figura 28 Desenho de Josi no sexto encontro

Figura 29 Desenho de Josi no sétimo encontro

Figura 30 Desenho 1 de Daniela no sétimo encontro

Figura 31 Desenho 2 de Daniela no sétimo encontro

Figura 32 Desenho 1 Gabriela no sétimo encontro

Figura 33

Desenho 2 de Gabriela no sétimo encontro

Figura 34

Desenho de Roberto no sétimo encontro.

Figura 35

Desenho 1 de Lucas no sétimo encontro

Figura 36 Desenho 2 de Lucas no sétimo encontro

Figura 37 Desenho 1 de Gabriela no oitavo encontro

Figura 38 Desenho 2 de Gabriela no oitavo encontro

Figura 39

Desenho 1de Josi no oitavo encontro.

Figura 40

Desenho 2 de Josi no oitavo encontro

Figura 41

Desenho 3 de Josi no oitavo encontro

Figura 42

Desenho 4 de Josi no oitavo encontro

Figura 43

Desenho 1 de Daniela no oitavo encontro

Figura 44 Desenho 2 de Daniela no oitavo encontro

Figura 45

Desenho de Roberto no oitavo encontro.

Figura 46

Desenho 1 de Lucas no oitavo encontro

Figura 47

Desenho 2 de Lucas no oitavo encontro.

Figura 48 Desenho 3 de Lucas no oitavo encontro

Figura 49

Desenho de Cecília no oitavo encontro.

Figura 50 Desenho de Paula no oitavo encontro 
Figura 51 Desenho de Meire no oitavo encontro.

Figura 52 Desenho de Kevin no nono encontro

Figura 53 Desenho de Maiara no nono encontro.

Figura 54

Desenho 1 de Guilherme no nono encontro.

Figura 55

Desenho 2 de Guilherme no nono encontro.

Figura 56

Desenho 3 de Guilherme no nono encontro

Figura 57 Desenho 4 de Guilherme no nono encontro

Figura 58 Desenho de Josi no nono encontro

Figura 59

Desenho de Gabriela no nono encontro

Figura 60

Desenho 1 de Guilherme no décimo encontro.

Figura 61

Desenho 1 de Josi no décimo encontro

Figura 62

Desenho 2 de Josi no décimo encontro

Figura 63 Desenho de 3 de Josi no décimo encontro

Figura 64 Desenho do filho da professora de informática no décimo encontro

Figura 65

Desenho de Maiara no décimo encontro.

Figura 66

Desenho coletivo no décimo primeiro encontro

Figura 67

Detalhe do desenho coletivo feito por Josi.

Figura 68 Detalhe do desenho coletivo feito por Guilherme

Figura 69 Detalhe de escrito feito por Josi

Figura 70 Detalhe do desenho coletivo feito por João.

Figura 71 Desenho coletivo no décimo segundo encontro.

Figura 72

Detalhe do desenho coletivo feito por Josi

Figura 73 Detalhe do desenho coletivo feito por Kevin

Figura 74 Detalhe do desenho coletivo feito por Maiara. 
Figura 76 Detalhe do desenho coletivo feito por Guilherme..................................... 167

Figura 77 Desenho feito por Leandro no décimo segundo encontro.......................... 166

Figura $78 \quad$ Desenho 2 de Leandro no décimo segundo encontro.................................. 168

Figura 79 Desenho de Paula no décimo segundo encontro....................................... 168

Figura 80 Desenho de Mariana no décimo segundo encontro.................................... 169

Figura $81 \quad$ Desenho 1 de Josi no décimo segundo encontro........................................ 169

Figura 82 Desenho 2 de Josi no décimo segundo encontro....................................... 170

Figura 83 Desenho 1 de Guilherme no décimo segundo encontro............................ 170

Figura 84 Desenho 2 de Guilherme no décimo segundo encontro............................. 171

Figura 85 Desenho de Kevin no décimo segundo encontro.................................... 171

Figura 86 Desenho de Mariana no décimo segundo encontro.................................... 172 


\section{SUMÁRIO}

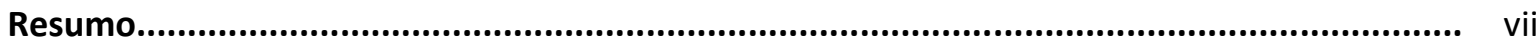

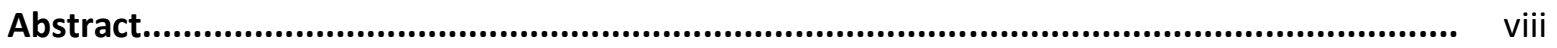

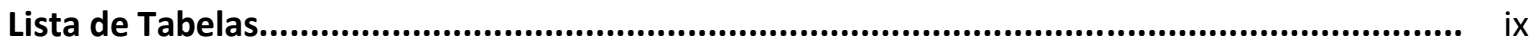

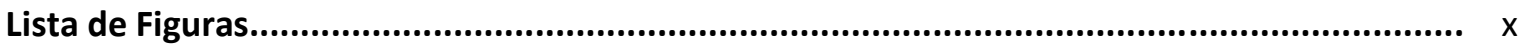

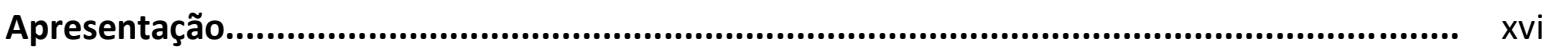

\section{INTRODUÇÃO}

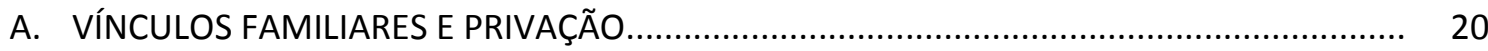

B. ABRIGO: ASPECTOS LEGAIS E PSICOSSOCIAIS................................................................ 25

1. Breve histórico das instituições de acolhimento no Brasil.......................................... 25

2. O abrigo como instituição............................................................................................ 28

3. Panorama atual dos abrigos no Brasil......................................................................... 30

4. O cuidador e o trabalho direto com crianças e adolescentes abrigados...................... 37

5. Aspectos psicológicos da institucionalização............................................................... 45

C. OFICINAS TERAPÊUTICAS.......................................................................................... 54

1. Fundamentos................................................................................................ 54

2. A pesquisa com oficinas terapêuticas no Laboratório de Saúde Mental e Psicologia Clínica Social do Departamento de Psicologia Clínica

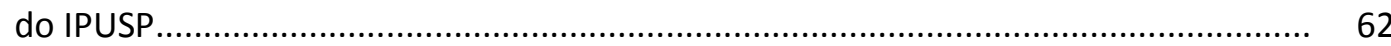

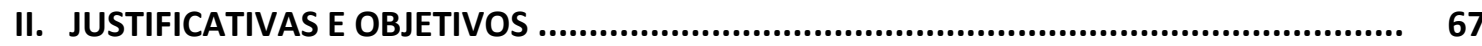

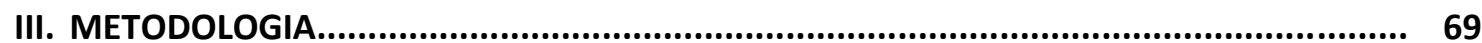

A. Breves considerações sobre o diagnóstico compreensivo

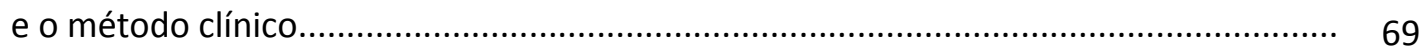

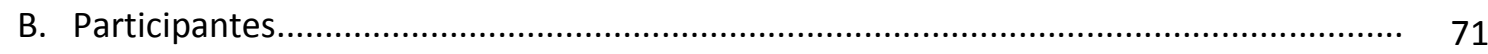

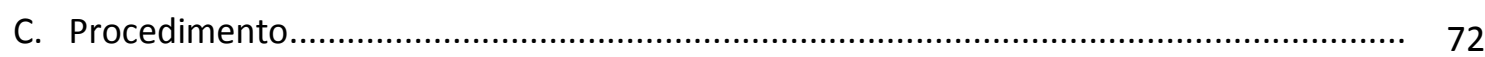

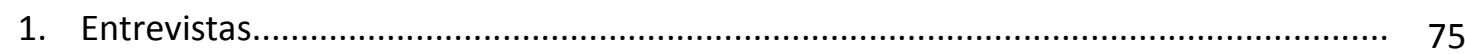

2. Desenho da Figura Humana (DFH) ..................................................................... 76

3. Desenho da Pessoa na Chuva............................................................................. 78

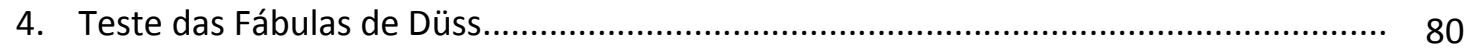

5. Inventário de Frases no Diagnóstico de Violência Doméstica (IFVD)............................ 81

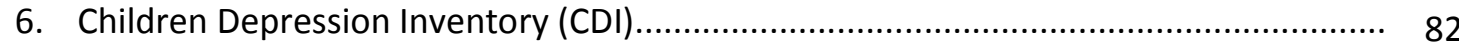

D. Oficinas terapêuticas. 


\section{APRESENTAÇÃO DOS PARTICIPANTES E}

1. Roberto - cuidador

a) Entrevista.

2. Gabriela - criança abrigada

a) Entrevista com Roberto

b) Entrevista com Gabriela..................................................................... 88

c) Procedimentos com Gabriela......................................................................... 89

3. Maiara - adolescente abrigada

a) Entrevista com Roberto............................................................................. 93

b) Entrevista com Maiara................................................................................ 93

c) Procedimentos com Maiara............................................................................ 94

4. Josi-adolescente abrigada

a) Entrevista com Roberto.............................................................................. 96

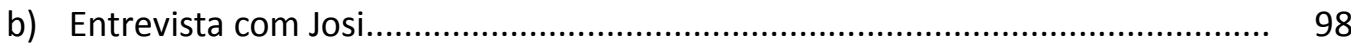

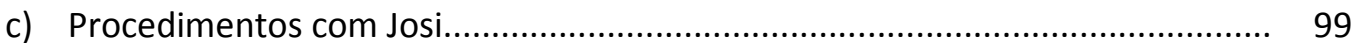

5. Síntese Geral....................................................................................... 102

V. RELATO DOS ENCONTROS DA OFICINA EXPRESSIVA DE DESENHO E PINTURA............. 104

VI. REAPLICAÇÃO DOS INSTRUMENTOS E ENTREVISTAS DEVOLUTIVAS............................ 173

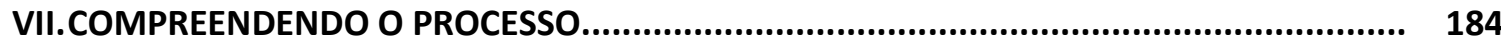

1. O primeiro encontro e seus principais tópicos................................................... 184

2. A chegada ao abrigo e o estabelecimento dos primeiros vínculos...................... 190

3. Os vínculos afetivos que se (re) constroem durante o acolhimento................... 198

4. O enquadre da Oficina como promovedor de experiências mutativas............... 214

VIII. CONSIDERAÇÕES FINAIS....................................................................................... 222

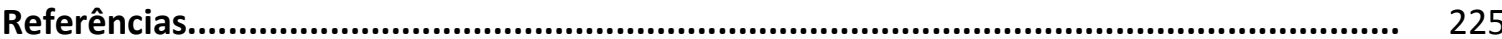

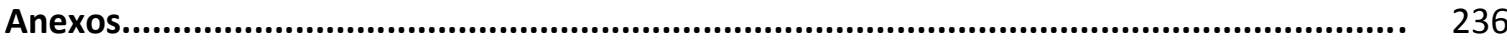




\section{APRESENTAÇÃO}

Desde as primeiras escolhas mais autônomas durante a graduação em Psicologia, meu olhar se direcionava para questões que o tempo amadureceu na presente dissertação de mestrado. No segundo ano de graduação (2005), realizei um projeto de Iniciação Científica, junto à Prof ${ }^{a}$ Drạ. Vera Bussab dentro do tema: apego e desenvolvimento humano. As relações entre crianças e seus cuidadores já chamavam a minha atenção e foi nesta circunstância que entrei em contato pela primeira vez com as ideias de Bowlby. Na época, minha pesquisa investigava a relação entre o estilo de apego de pais e filhos, buscando compreender como o estilo relacional dos pais influenciava o dos filhos. Concomitante a esta pesquisa, desenvolvia-se um projeto temático financiado pela FAPESP e coordenado pelas professoras Emma Otta e Vera Bussab (Projeto Ipê) cujo objetivo era um estudo amplo dos efeitos da depressão pós parto. Finalizado o primeiro projeto de iniciação científica iniciei um segundo projeto voltado para os efeitos da depressão pós parto no vínculo mãe-bebê. O meu interesse pelo tema, dirigiu-se para implicações da falha materna no desenvolvimento humano, ou seja, como a depressão afetava estes primeiros laços. Com este projeto, ganhei Menção Honrosa PIBIC/CNPq em 2007.

Concluída esta pesquisa, iniciei as disciplinas de atendimento psicológico e percebi que era sob o enfoque clínico que gostaria de olhar para estas questões. No quarto ano de graduação (2007), realizei um estágio de um ano em um abrigo em São Paulo. Sob supervisão da psicóloga técnica da clínica escola Durval Marcondes do Instituto de Psicologia da USP, Yara Sayão, desenvolvi um trabalho pautado na Psicologia Escolar. O olhar clínico era estimulado durante as supervisões, mesmo que não se tratasse de terapia propriamente dita o que eu e minhas colegas fazíamos. Neste trabalho, iniciou-se minha experiência com grupos de crianças abrigadas, bem como o uso de materiais intermediadores - gibis, livros, cartas entre outros.

Por impossibilidade de conciliar os diversos compromissos acadêmicos, me desliguei do grupo que trabalhava com crianças abrigadas ao mesmo tempo em que 
me voltava para a atuação clínica. Apesar do afastamento, a experiência de trabalhar com estas crianças nunca saiu da minha memória e aguardava outra oportunidade para voltar a trabalhar com elas.

Foi mais adiante que descobri os enfoques diferenciados inspirados na teoria Winnicott desenvolvidos pela Profá ${ }^{-}$Tania Aiello-Vaisberg. Este tipo de atuação reforçaram em mim o desejo de ter uma prática clínica pautada por diretrizes mais flexíveis do que o enquadre psicanalítico clássico, além da possibilidade do uso de materiais expressivos como mediadores do contato terapêutico. Essas escolhas já ressaltavam aspectos pessoais que culminaram no meu ingresso no curso de Artes Visuais na Escola de Comunicação e Artes da Universidade de São Paulo no ano imediato à conclusão do curso de Psicologia. Dentro das Artes Visuais, optei pela habilitação de Gravura - prática que engloba todas as vertentes gráficas artísticas: fotografia, desenho e as diversas modalidades de gravura (gravura em metal, xilogravura, litogravura, serigrafia).

Em 2007 comecei a fazer parte do Laboratório de Saúde Mental e Psicologia Clínica Social - APOIAR. A minha permanência neste laboratório persiste até os dias de hoje e acompanhou a definição da minha área de interesse e consequentemente do projeto de mestrado. Em 2009, psicóloga e estudante de Artes Visuais, vi no núcleo do APOIAR que atende crianças e adolescentes abrigados a possibilidade de voltar a atuar junto a esta população. Desde então, desenvolvo atendimentos clínicos individuais voltados às crianças e adolescentes moradores de casas abrigo. Ao longo desta experiência, fui percebendo o quanto a equipe de educadores que trabalham diretamente com as crianças e adolescentes abrigados possuem questões específicas que se refletem no relacionamento com os mesmos. Volto, então, para a questão dos vínculos entre crianças e seus cuidadores (agora não mais a mãe ou pai).

Integrando a minha prática como psicóloga clínica ao meu interesse pelos enquadres diferenciados e o uso de uma materialidade gráfica, surgiu a proposta para a seguinte dissertação que se intitula: Oficinas expressivas de desenho e pintura com crianças e adolescentes abrigados e seu cuidador. A escolha pela materialidade mediadora deve dizer respeito diretamente a materiais com os quais o terapeuta se relaciona autentica e criativamente. Relaciono diretamente a minha 
opção de formação dentro das Artes Visuais (Gravura) à materialidade escolhida para o desenvolvimento da oficina expressiva.

A Gravura nada mais é do que um entalhe feito numa matriz (madeira, chapa de metal, pedra, linóleo entre outros) que é entintada e comprimida sobre uma superfície (normalmente o papel), deixando impressa uma marca. A prática da Gravura encontra-se intimamente relacionada ao desenho, ao passo que este, muitas vezes, se constitui como um momento preliminar no qual a imagem é explorada, estudada, para então ser gravada e impressa. O desenho, a lápis, tinta ou qualquer outro material é uma prática pessoal minha de observação e apreensão do mundo que me rodeia. Acredito que o desenho, a Gravura ou qualquer outra forma manifestação artística é uma maneira de apropriação, organização e ressignificação do mundo e das experiências mais subjetivas. E neste ponto, vejo inúmeras semelhanças à prática clínica.

Uma vez delimitado o campo de pesquisa, foi sugerido, pela minha orientadora do Mestrado a Professora Doutora Leila Tardivo, que desenvolvesse meu projeto junto a um abrigo na Grande São Paulo. O motivo era a dificuldade de acesso a este tipo de trabalho que costuma se concentrar na capital pela abundância de cursos superiores em comparação aos municípios vizinhos. Desta forma, apresentou-se ao abrigo a proposta de trabalho e iniciou-se a experiência que será apresentada a seguir.

As páginas que se seguem trazem o relato da experiência da Oficina Expressiva de Desenho e Pintura que objetivou a compreensão das vivências emocionais de crianças e adolescentes abrigados, tanto no que concerne à relação entre eles como com seu cuidador e a instituição.

Sendo assim, o trabalho foi dividido em capítulos que buscam reunir os elementos que nortearam a experiência bem como toda a discussão e produção de conhecimento.

O primeiro capítulo é dedicado à Introdução, tratando dos temas que embasam o estudo. A primeira parte dedicou-se a abordar a importância dos vínculos familiares e as questões que envolvem a privação dos mesmos. A segunda 
parte trata do abrigo como instituição de acolhimento de crianças e adolescentes, contendo um breve histórico e um panorama atual dessas instituições no Brasil. Ainda neste segmento procurou-se inspecionar as problemáticas que envolvem o cuidador, profissional que trabalha diretamente com as crianças e adolescentes; e ainda problematizar as marcas psicológicas da institucionalização na população abrigada. Na terceira e última parte deste capítulo, discorreu-se sobre as oficinas terapêuticas: seus fundamentos teóricos e pesquisas dentro do Laboratório de Saúde Mental e Psicologia Clínica Social do Departamento de Psicologia Clínica do IPUSP sob a coordenação da Prof ${ }^{\mathfrak{a}}$ Livre Docente Leila Salomão de La Plata Cury Tardivo.

No segundo capítulo, estão expressas as justificativas e objetivos deste trabalho. Em seguida, os aspectos metodológicos compõem o Capítulo III. Inicia-se por uma explanação acerca do método clínico e do psicodiagnóstico compreensivo, ambos constituíram-se como importante arcabouço para fundamentar a pesquisa. $\mathrm{Na}$ continuação, encontram-se as etapas que envolveram o procedimento e os instrumentos utilizados.

Os resultados da pesquisa estão expostos nos dois capítulos seguintes. Isso porque se compreendeu que o presente trabalho abrange dois aspectos diversos: 0 psicodiagnóstico breve e o processo da Oficina Expressiva. Estas duas partes complementaram-se na compreensão das vivências emocionais dos participantes do grupo.

Desta forma, o quarto capítulo contempla a apresentação dos participantes do estudo através dos resultados obtidos nas entrevistas e na aplicação dos instrumentos. No quinto capítulo é apresentado o relato dos encontros da Oficina Expressiva de Desenho e Pintura.

No Capítulo VI encontramos os dados referentes à reaplicação dos instrumentos e as entrevistas finais, tanto com os participantes do grupo como com a coordenadora da instituição. No Capítulo VII temos a discussão do processo, que engloba desde as entrevistas iniciais, os encontros mediados pelo desenho e pela pintura assim como a reaplicação dos instrumentos e as entrevistas finais. E finalmente no oitavo capítulo são expressas a síntese e as considerações finais. 


\section{I) INTRODUÇÃO}

Neste capítulo serão abordados aspectos teóricos e relatos de experiências com os quais o presente estudo tem relação e se embasam. Dentro destas áreas e com estes autores será possível fazer um diálogo e considerações a partir do observado e vivido no estudo que compõe esta dissertação. Inicialmente apresenta-se uma discussão teórica sobre os vínculos familiares e sua relevância na formação da personalidade com inspiração nas ideias de Winnicott e Bowlby principalmente.

\section{A. VÍNCULOS FAMILIARES E PRIVAÇÃO}

A criança pequena é um ser dependente e por isso necessita de alguém que a ajude durante esse período de imaturidade. É neste processo de cuidado que os vínculos afetivos são construídos e a mãe representa este cuidador por excelência. Mas para desempenhar esta função, ela conta com toda uma rede formada pelo pai, outros familiares e conhecidos que a sustentam enquanto desempenha este papel.

De acordo com Bowlby (1985) há uma tendência inata pela estruturação de vínculos fortes e persistentes entre seres humanos, que busca, etologicamente falando, o sucesso da manutenção da espécie, mas que não estão somente ligados à satisfação de necessidades orgânicas como a forme.

A mãe deve auxiliar o bebê em duas categorias: na satisfação das necessidades físicas imediatas, tais como a alimentação, calor, abrigo e proteção (BOWLBY, 1976/2001; WINNICOTT, 1988/2006); e numa série de necessidades sutis que, de acordo com Winnicott (1988/2006) só o cuidado humano pode suprir: 


\begin{abstract}
"Talvez o bebê precise deixar-se envolver pelo ritmo respiratório da mãe, ou mesmo ouvir e sentir os batimentos cardíacos de um adulto. Talvez seja-lhe necessário sentir o cheiro da mãe ou do pai, ou talvez ele precise ouvir sons que lhe transmitam vivacidade e a vida que há no meio ambiente, ou cores e movimentos, de tal forma que o bebê não seja deixado a sós com seus próprios recursos, quando ainda muito jovem e imaturo para assumir plena responsabilidade pela vida". (WINNICOTT, 1988/2006:75).
\end{abstract}

O ambiente capaz de atender às necessidades básicas de uma criança sem Ihe causar invasões é qualificado como suficientemente bom. Para isto, não basta que a mãe esteja apenas fisicamente disponível. É preciso que ela esteja pessoalmente bem para que consiga sustentar o processo do vir a ser da criança que gradualmente supera a extrema dependência materna, constituindo seu self rumo à independência (WINNICOTT, 1990).

O cuidado com a satisfação de tais necessidades resguarda a criança de ansiedades terríveis que Winnicott (1988/2006) traduziu em termos como: "ser feito em pedaços; cair para sempre; morrer e morrer e morrer; perder todos os vestígios de esperança de renovação de contatos" (Winnicott (1988/2006):76).

\begin{abstract}
Um fato importante a considerar é que, graças a uma assistência satisfatória, estes sentimentos terríveis se transformam em experiências positivas, vindo somar-se à confiança que o bebê adquire com relação ao mundo e às pessoas. Ser feito aos pedaços, por exemplo, passará a ser uma sensação de relaxamento e repouso se o bebê estiver em boas mãos; cair para sempre se transforma em alegria de ser carregado, e no entusiasmo e prazer que decorrem do movimento; morrer e morrer e morrer passa a ser a consciência deliciosa de estar vivo, e quando, a constância vier em auxílio à dependência, a perda de esperança quanto aos relacionamentos se transformará numa sensação de segurança, de que, mesmo quando a sós, 0 bebê tem alguém que se preocupa com ele (WINNICOTT, 1988/2006:76).
\end{abstract}

Sem uma pessoa que cumpra este papel de cuidador, a criança não pode descobrir o seu corpo, aprender a amar e odiar (e consequentemente descobrir o sentimento de culpa e o desejo de reparação); observar que suas ideias agressivas não são realmente capazes de destruir (separando, então, fantasia de realidade). De forma concisa, é possível dizer que esta ausência torna difícil o desenvolvimento de uma personalidade integrada (WINNICOTT, 1987/1999). 
A vida em família é de extrema importância para a constituição de um indivíduo saudável (SILVA, LEONCIO \& TARDIVO, 2007). Quando a criança é provida por uma maternagem suficientemente boa, seu desenvolvimento emocional se direciona para a saúde psíquica, rumo à aquisição de um self verdadeiro, a integração do eu no tempo e a personalização. Para que isso aconteça, é fundamental que ambos - mãe e filho - encontrem satisfação e prazer. Para tanto, é imprescindível que ambos se sintam profundamente identificados um com o outro (BOWLBY, 1976/2001). O autor coloca:

\begin{abstract}
No momento, basta dizer que o que se acredita ser essencial à saúde mental é que o bebê e a criança pequena tenham a vivência de uma relação calorosa, íntima e contínua com a mãe (ou mãe substituta permanente uma pessoa que desempenha, regular e constantemente, o papel de mãe para eles), na qual ambos encontrem satisfação e prazer. É esta relação complexa, rica e compensadora com a mãe, nos primeiros anos, enriquecida de inúmeras maneiras pelas relações com o pai e com os irmãos, que os psiquiatras infantis e muitos outros julgam, atualmente, estar na base do desenvolvimento da personalidade e saúde mental. (BOWLBY, 1976/2001:3).
\end{abstract}

Segundo Winnicott (1990), os bebês podem sobreviver mesmo que não tenham alguém que desempenhe o papel de um cuidador dedicado. Porém, algo estará faltando dentro deles, “(...) resultando numa intranquilidade e numa falta de capacidade de concern, na ausência de profundidade e na incapacidade para o brincar construtivo" (p.176).

Winnicott (1987/1999) afirma que, quando um bom ambiente é desfeito ou quando nunca existiu um bom ambiente, é possível notar reações de ódio reprimido, perda da capacidade de amar as pessoas, instalação de organizações defensivas na personalidade da criança, regressão para fases anteriores do desenvolvimento emocional que foram mais satisfatórias, estado de introversão patológica e até a cisão da personalidade (WINNICOTT, 1987/1999: 199).

É importante salientar que, num determinado momento do seu desenvolvimento, o bebê precisa ser malsucedido na sua adaptação, mas estas falhas precisam acontecer de forma gradual (WINNICOTT, 1988/2006). O ideal é que ocorram num momento em que a criança já dispõe de mecanismos que the permitam conviver com estas frustrações. Porém, muitas crianças vivenciam falhas no cuidado tão intensas que podem prejudicar a sua continuidade de ser. E muitas 
vezes estas experiências se constituem como motivos para que crianças e adolescentes sejam afastados da família.

Devido à importância do vínculo familiar, a decisão de se separar uma criança de seus pais é muito séria e acarreta numa série de consequências que a afetarão em maior ou menor grau. Segundo Bowlby (1976/2001) os prejuízos se tornam mais graves quanto mais nova é a criança separada de seus pais. $O$ resultado de uma separação abrupta pode ser catastrófico:

(...) em numerosos grupos de pacientes psiquiátricos, a incidência de rompimentos de vínculos afetivos durante a infância é significativamente elevada. Embora estes últimos estudos confirmem as conclusões anteriores a respeito da maior incidência de perda da mãe durante os primeiros anos da infância, eles também as ampliam. Para vários tipos de condições, sabese agora que as maiores incidências de vínculos afetivos desfeitos incluem tanto os vínculos com os pais como com as mães, e são observados entre os cinco e os catorze anos, tanto quanto nos primeiros cinco anos. Além disto, em condições mais extremas - sociopatia e tendências suicidas - não só é provável que uma perda inicial tenha ocorrido nos primeiros anos de vida, mas também é provável que tenha sido uma perda permanente, seguida da experiência de repetidas mudanças de figuras parentais (BOWLBY, 1997: 104).

Winnicott (1987/1999) chega à mesma conclusão ao trabalhar com crianças separadas de suas mães durante a guerra:

(...) quanto mais jovem for a criança, menor será a sua capacidade para manter viva em si mesma a ideia de uma pessoa; quer dizer, se ela não vir uma pessoa, ou não tiver provas tangíveis de sua existência em $x$ minutos, horas ou dias, essa pessoa estará morta para ela (WINNICOTT, 1987/1999: 11).

Esta dificuldade de manter viva a ideia de alguém amado, segundo Winnicott (1987/1999) pode resultar numa sensação de perda de sentimento. Assim, estas crianças podem desenvolver uma série de comportamentos para recuperar o sentimento de realidade: procurar confusão, enurese noturna, irritações cutâneas, bater a cabeça etc. O próprio autor aponta que a compreensão é o melhor que se 
pode fazer para auxiliar na superação desta angústia. Para estabelecer contato com alguém que sofreu uma perda afetiva, Bowlby (1997) ressalta a importância do respeito aos sentimentos e empatia.

Bowlby (1976/2001) ao estudar crianças mais velhas separadas de suas famílias durante a guerra, afirma que, ao contrário do que ocorre com as crianças mais novas, quanto melhor tiver sido o relacionamento entre as crianças e suas mães, melhor será a tolerância à separação. Uma criança segura de que a mãe a ama, não ficará extremamente angustiada. Já aquela que tem dúvidas em relação ao amor da mãe por ela fica facilmente sujeita a uma interpretação errônea dos fatos. A crença de que foi mandada embora por causa de sua maldade leva a um sentimento de angústia e ódio que criam um círculo vicioso na relação com estes pais.

Em relação a este vínculo ambivalente que se forma entre a criança e seus pais, podemos encontrar em Bowlby (1976/2001:70) algumas palavras que nos auxiliam nesta compreensão. $O$ autor atesta que, mesmo maus pais proporcionam muitas coisas aos filhos. Com exceção dos piores casos, eles fornecem alimento, abrigo, conforto para algumas angústias ensinam-Ihes pequenas coisas. Diante desses cuidados, mesmo que sujas ou maltratadas, as crianças experimentam certa segurança ao lado destes pais (a não ser que eles a rejeitem completamente), pois, nas palavras de Bowlby (1976/2001), sabem que possuem algum valor para alguém, que cuida delas mesmo inadequadamente. A ligação destas crianças com estes pais produz uma eterna fonte de surpresas para aqueles que procurar ajudar tais crianças. Leoncio e Tardivo (2007) apontam em um artigo o quanto crianças abrigadas possuem o intenso desejo de retornar à família, mesmo tendo vivido experiências desagradáveis e até mesmo traumáticas. Para tais crianças, uma vez longe de seus lares, é difícil encontrar alguém constante que cuide delas até que cresçam e, portanto, tornam-se muito desconfiadas, agarrando-se às suas raízes, ainda que não sejam as mais exemplares.

Estes dados nos fazem retomar a importância do vínculo familiar e a enorme responsabilidade de se retirar uma criança de perto de seus pais. Se por um lado temos os cuidados maternos como fundamentais para o desenvolvimento emocional de toda criança, por outro é impossível negar que ocorram falhas muito graves no 
cuidado, que tornam o ambiente familiar muito prejudicial. São nestes casos extremos que temos os abrigos como alternativa. E é sobre esse tipo de instituição que trataremos a seguir.

\section{B. ABRIGO: ASPECTOS LEGAIS E PSICOSSOCIAIS}

\section{Breve histórico das instituições de acolhimento no Brasil}

Os primeiros trabalhos voltados à assistência de crianças que temos notícia foram realizados pelos jesuítas, que acolhiam órfãos e filhos dos gentios durante o período colonial (SOUZA NETO, 2001). As "Casas dos Muchachos" tinham como objetivo, por volta da década de 1550, "civilizar" as crianças indígenas, que criadas junto de órfãos de origem portuguesa, podiam ter nestes últimos, um modelo para aprender os modos, tidos, civilizados (FREITAS, 2001, apud PINEDA, 2012).

No século XVIII, o país começou a assistir o crescimento das cidades proporcionado pela atividade mineradora. Como consequência, começou a aumentar o número de crianças abandonadas em locais públicos:

\footnotetext{
[...] à noite, nas ruas sujas, frequentemente era devorados pelos cães e por outros animais que rondavam a capital brasileira. Em outras ocasiões, morriam simplesmente de fome ou de exposição aos elementos. Algumas mães deixavam os filhos nas naves das igrejas ou às portas dos conventos, na esperança de que algum padre ou freira bondosos os alimentassem e Ihes conseguissem um lar. Outras abandonavam as crianças na praia, para que se afogassem com a maré enchente. (RUSSELL-WOOD, 1981, apud SOUZA NETO, 2001: 93).
}

Nesse contexto, surgem no Brasil as Santas Casas de Misericórdia. As crianças lá recebidas eram criadas por uma ama de leite geralmente até os três anos (SPUZA NETO, 2001). Por falta de recursos, a instituição procurava logo empregar os órfãos já aos sete anos, tanto como aprendizes no caso dos meninos (nas Companhias de Marinheiros ou no Arsenal de Guerra, nos quais conviviam com 
presos e degredados), quanto domésticas no das meninas (VENANCIO, 1999). De acordo com Rizzini e Rizzini (2004), neste período, “o número de meninos enviados pelas companhias imperiais aos navios de guerra foi maior do que o de homens recrutados e voluntários." (RIZZINI; RIZZINI, 2004: 25).

Nesta época observou-se no Brasil a retomada de um instrumento utilizado na Europa medieval: a roda dos expostos ${ }^{1}$ que persistiria como prática por mais de 200 anos. Até o fim do segundo reinado, seriam treze em funcionamento em todo país. A maioria das crianças deixada nas rodas dos expostos era de filhos de mães brancas, num universo moral que rejeitava o adultério e o relacionamento sexual antes do casamento (LEITE, 1991; MESGRAVIS, 1972; RUSSEL-WOOD, 1981 apud SOUZA NETO, 2001). Mesmo porque, nesta época, crianças negras eram consideradas propriedades e tinham valor de mercado.

Ao longo do século XIX, sob a influência do ideário iluminista e os novos conceitos de progresso e civilização, os projetos educacionais ocidentais passaram por uma reformulação. A medicina social ganhou maior poder político e respaldo social através da crescente intervenção dos médicos higienistas com suas inúmeras críticas à estrutura urbana e moral a sua volta. Inicialmente saudada e apoiada, a roda e os asilos fundados e mantidos pela caridade vão se tornar alvo de intensas críticas. No que concerne à Casa dos Expostos, apontavam principalmente as altas taxas de mortalidade, os maus tratos dirigidos às crianças pelas amas, a educação quase que exclusivamente religiosa, o tratamento indiscriminado e não especializado destinado às crianças e o desrespeito aos preceitos de higiene (MARCÍLIO, 1998; RIZZINI, 1993).

Durante esse século, as Casas de Misericórdia foram gradativamente perdendo a autonomia, ficando a serviço do Estado e sob seu controle, já que dele dependiam financeiramente. Foram sobre essa base que se estruturaram as primeiras propostas de políticas públicas voltadas para a criança abandonada

\footnotetext{
${ }^{1}$ As rodas eram cilindros rotatórios de madeira usados em mosteiros como meio de se enviar objetos, alimentos e mensagens aos seus residentes. Rodava-se o cilindro e as mercadorias iam para o interior da casa, sem que os internos vissem quem as deixara. A finalidade era a de se evitar o contato dos religiosos enclausurados com o mundo exterior, garantindo-lhes a vida contemplativa. Como os mosteiros medievais recebiam crianças doadas por seus pais, para o serviço de Deus, muitos pais que "abandonavam" seus filhos utilizavam a roda dos mosteiros para nela depositarem o bebê. Desse uso indevido das rodas dos mosteiros, surgia o uso da roda para receber os expostos, fixada os muros dos hospitais para cuidar das crianças abandonadas. Assim, o nome da roda provém deste dispositivo (Marcílio, 1999).
} 
(BAPTISTA, 2006). E por volta de 1920, a questão, que já era estatal, foi transformada em legal através da Lei № 4.242, de 1921:

\begin{abstract}
"que trata da despesa geral do país, em seu artigo terceiro, entre outros tópicos, autoriza o governo a organizar o serviço de assistência e proteção à infância abandonada e delinquente e determina a construção de abrigos para o recolhimento provisório dos menores de ambos os sexos, que fossem encontrados abandonados ou que tivessem cometido crime ou contravenção; nomeação de juiz de direito privativo de menores, assim como de funcionários necessários ao respectivo juiz; providências para que os menores que estivessem cumprindo sentença em qualquer estabelecimento, fossem transferidos para a casa de reforma após sua instalação". (FERNANDES, 1998, apud BAPTISTA, 2006: 28).
\end{abstract}

Em 1927, por meio do Decreto no 17.943-A, foi constituído o Código de Menores, que se tornou conhecido como Código Mello Mattos, consolidando as leis de assistência e proteção a menores (BAPTISTA, 2006; RIZZINI, 1993).

Algumas emendas foram feitas ao Código Mello Mattos e constantes debates foram realizados para aperfeiçoar a assistência às crianças. Em 1964, a situação política do país passou por uma grande mudança: os militares assumem o governo e propõem a criação da FUNABEM (Fundação Nacional do Bem-Estar do Menor) através da Lei o 4.513 (BAPTISTA, 2006). O autor relata que a questão da criança e do adolescente passou a ser visto como um problema de segurança nacional e, portanto, enfrentado de forma estratégica, por meio de um conjunto de medidas legislativas, administrativas e políticas. Em pouco tempo, ficou claro que essas diretrizes não se concretizariam, principalmente, em razão da estrutura altamente centralizadora da FUNABEM e da permanência da priorização da internação como medida de segregação dos menores marginalizados. Nessa época, era comum crianças e adolescentes serem abrigados em complexos de atendimento, semelhantes aos antigos reformatórios e orfanatos, isolados da malha urbana e distantes da vida em comunidade. Suas estruturas eram montadas de forma a impedir o contato com o mundo externo, mantendo, no seu interior, escolas, quadras esportivas, piscinas, núcleo profissionalizante, além de atendimento médico, odontológico e enfermarias (BAPTISTA, 2006). Seu sistema de funcionamento era baseado na segregação por gênero e por idade, e na massificação: as crianças e os adolescentes eram distribuídos por módulos (com capacidade para abrigar mais ou 
menos 100 em cada um), de acordo com o sexo e a faixa etária, separando irmãos e parentes (BAPTISTA, 2006).

Na década de 1980, com o fim da Ditadura Militar ocorreu um fortalecimento da cultura democrática e a movimentação de diferentes grupos possibilitou a criação do Fórum Permanente de Defesa da Criança e do Adolescente (Fórum DCA) (BAPTISTA, 2006). Esse fórum, então, organizou-se em torno da necessidade de inclusão, na nova Constituição, de cláusulas que garantissem uma legislação específica para crianças e adolescentes. E em 1990 foi promulgado o ECA ${ }^{2}$ (Estatuto da Criança e do Adolescente) (BRASIL, 1990/2005), que será melhor discutido a seguir.

\section{O abrigo como instituição}

O abrigo se organiza como uma instituição nos moldes do que teorizou Bleger $(1984,1988)$ e Kaës $(1991,2011)$ uma vez que se configura como um conjunto de normas, atitudes e estruturas pautadas no campo cultural e social, seguindo, portanto, uma lógica própria. Segundo Kaës (1991), as instituições regulam nossas relações, preexiste e se impõem a nós. O autor afirma que a instituição ocupa um duplo status psíquico: de anexo e depósito. Desta forma, ela cumpre dois papéis fundamentais: de estruturação e de receptáculo do indiferenciado (KAËS, 1991).

Da mesma forma como uma mãe está na base das experiências de descontinuidade que regem a díade necessidade/satisfação, a instituição assegura a satisfação de determinadas necessidades psíquicas dos indivíduos a ela vinculados. Assim, ela pode se oferecer como objeto ideal a ser interiorizado, porém, não raro, assume um papel persecutório também (KAËS, 1991).

Bleger (1984) já explicitara que toda instituição tem objetivos específicos e uma organização própria para atingi-los. No entanto, estes objetivos podem ser explícitos ou implícitos, manifestos ou latentes. Com o ECA (BRASIL, 1990/2005), os objetivos explícitos de uma casa abrigo se instituíram. As principais mudanças em

${ }^{2}$ Estatuto da Criança e do Adolescente aprovado pela Assembleia Geral da ONU em 20 de novembro de 1989 e promulgado em 13 de julho de 1990 (Lei 8.069). 
relação ao modelo anterior dizem respeito à superação de uma estrutura assistencialista em prol de ações emancipatórias, com base na noção de cidadania, encarando crianças e adolescentes como sujeitos de direito (IPEA, 2003).

A partir da promulgação do ECA (BRASIL, 1990/2005), os grandes complexos que abrigavam, até então, crianças e adolescentes passaram por um remanejamento e assim, surgiu um novo conceito de abrigo:

"que se caracteriza pela garantia de atendimento personalizado e de respeito à identidade dos usuários, com instalações físicas adequadas, salubridade, segurança, educação e cuidados médicos e psicológicos" (SOUZA NETO, 2001: 94).

O acolhimento institucional, até pouco tempo chamado de abrigamento (PINEDA, 2012:14), se trata de uma medida provisória e excepcional (BRASIL, 1990/2005, art. 101, parágrafo único) que implica na suspensão temporária do poder familiar sobre crianças e adolescentes em situação de risco e se dá apenas por decisão do Conselho Tutelar $^{3}$ e determinação judicial ${ }^{4}$ (IPEA, 2003; LEONCIO, 2003; CARETA, 2011). Visa à proteção dos direitos das crianças e adolescentes com o objetivo de reintegrá-los ao círculo familiar ou, na impossibilidade deste, a uma família substituta. Neste período de institucionalização, a guarda destas crianças e adolescentes compete ao responsável pelo abrigo, devendo ser acompanhado pelas autoridades competentes (IPEA, 2003).

No art. 92 do ECA, (BRASIL, 1990/2005:36), que trata das Entidades de Atendimento, estão determinados os princípios que deverão ser adotados pelas entidades que desenvolvem programas de abrigo, propostos com as seguintes finalidades:

I. Preservação dos vínculos familiares

II. Integração em família substituta, quando esgotados os recursos de manutenção na família de origem;

III. Atendimento personalizado e em pequenos grupos;

\footnotetext{
${ }^{3}$ O Conselho Tutelar é órgão permanente e autônomo, não juridicional, encarregado pela sociedade de zelar pelo cumprimento dos direitos da criança e do adolescente (BRASIL, 1990/2005, art. 131).

${ }^{4}$ As competências da Justiça da Infância e da Juventude poderão ser consultadas no art. 148 e 149 do ECA (BRASIL, 1990/2005).
} 
IV. Desenvolvimento de atividades em regime de coeducação;

V. Não desmembramento de grupo de irmãos;

VI. Evitar, sempre que possível, a transferência para outras entidades de crianças e adolescentes abrigados;

VII. Participação da vida da comunidade local;

VIII. Preparação gradativa para o desligamento;

IX. Participação de pessoas da comunidade no processo educativo.

Ainda no art. 94 do ECA (BRASIL, 1990/2005:36), leem-se as obrigações de tais entidades, entre elas observar os direitos e garantias das crianças e adolescentes, oferecer vestuário, propiciar escolarização, além de atividades culturais e esportivas; assistência religiosa aos que solicitarem, cuidados médicos, psicológicos, odontológicos etc.

Glens (2010) faz questão de não cultivar um falso triunfalismo diante da promulgação do ECA que foi de fato inovadora, afirmando que esta legislação específica representa um ideal a ser atingido, mas não reflete necessariamente uma realidade encontrada cotidianamente nos abrigos em sua maioria. Careta (2011) destaca que as entidades que oferecem $o$ acolhimento institucional a crianças $e$ adolescentes em situação de risco não possuem um rigor ao seguir estes princípios apontados pelo ECA. Além das questões de políticas públicas envolvidas, a autora relaciona esta falha à precariedade emocional do corpo funcional institucional. $\mathrm{O}$ contexto do abrigo marcado pelo abandono e o rompimento de vínculos despertam as dificuldades emocionais nos funcionários da instituição. Esse assunto será melhor abordado no tópico destinado aos cuidadores.

\section{Panorama atual dos abrigos no Brasil}

O levantamento quantitativo da realidade dos abrigos no nosso país não é extenso e consideravelmente obsoleto. Porém nos valeremos de três pesquisas, duas delas realizadas há 10 anos e outra ainda em andamento, para traçar um cenário da institucionalização de crianças e adolescentes. A opção por expormos 
estes dados recai na atualidade dos mesmos, ainda que as pesquisas refiram-se a resultados de alguns anos atrás.

A primeira delas foi promovida pela Secretaria Especial dos Direitos Humanos (SEDH) da Presidência da República e realizada pelo IPEA (Instituto de Pesquisa Econômica Aplicada), denominando-se: "Levantamento Nacional de Abrigos para Crianças e Adolescentes da Rede SAC/MDS" (IPEA, 2003). A segunda delas intitulada: "Por uma política de abrigos em defesa de direitos das crianças e dos adolescentes da cidade de São Paulo" (AASPTJ-SP; NCA-PUC-SP; SAS; FUNDAÇÃO ORSA, 2003) foi elaborada também em 2003 a partir de uma parceria entre a SAS (Secretaria Municipal de Assistência Social do Estado de São Paulo), a Fundação Orsa, o NCA-PUC-SP (Núcleo de Estudos e Pesquisas sobre a Criança e o Adolescente da Pontifícia Universidade Católica de São Paulo) e a AASPTJ-SP (Associação dos Assistentes Sociais e Psicólogos do Tribunal de Justiça do Estado de São Paulo). Por último, mencionaremos uma pesquisa ainda em andamento realizada pela Secretaria Nacional de Assistência Social do Ministério do Desenvolvimento Social e Combate à Fome em parceria com a Fundação Oswaldo Cruz (SNAS/MDS; FIOCRUZ), cujo nome é: "Levantamento nacional de crianças e adolescentes em serviços de acolhimento" (SNAS/MDS; FIOCRUZ, 2010).

Das 670 instituições de acolhimento que recebiam auxílio federal, 589 foram investigadas pelo IPEA (2003), nas quais havia 19.373 crianças e adolescentes. Dentre as instituições pesquisadas, 49,1\% estão localizadas na região sudeste e mais de um terço $(34,1 \%)$ no Estado de São Paulo, sendo a maior concentração em áreas urbanas $(90,3 \%)$.

Baseados no art. 92 do ECA (transcrito anteriormente) foram analisados os aspectos que permitiam avaliar o grau de adequação do atendimento dos abrigos. Dos 589 abrigos, 5,8\% incentivam a convivência com a família de origem e não separam grupos de irmãos; 14,1\% apoia a reestruturação familiar com medidas como a visita domiciliar, acompanhamento social, realização de grupos de apoio etc.; $22,1 \%$ incentivam a relação com outras famílias (inserção em famílias substitutas, apadrinhamento); 27,5\% incentivam a participação da comunidade no processo educativo (voluntariados). 
Embora conste no art. 23 do ECA (BRASIL, 1990/2005) que a falta ou a carência de recursos materiais não se configura como motivo suficiente para a perda ou suspensão do poder familiar, os dados levantados pelo IPEA (2003) e pela AASPTJ-SP; NCA-PUC-SP; SAS; FUNDAÇÃO ORSA (2003) nos oferecem outro ponto de vista. Segundo estas pesquisas, os principais motivos que levam ao acolhimento institucional são:

\begin{tabular}{|c|c|c|c|}
\hline \multicolumn{2}{|c|}{$\begin{array}{l}\text { Levantamento Nacional (IPEA, } \\
\qquad \text { 2003) }\end{array}$} & \multicolumn{2}{|c|}{$\begin{array}{l}\text { Levantamento Regional (AASPTJ-SP; NCA-PUC-SP; } \\
\text { SAS; FUNDAÇÃO ORSA, 2003) }\end{array}$} \\
\hline Abandono & $18,9 \%$ & Abandono e/ou negligência & $22,3 \%$ \\
\hline Pobreza & $24,2 \%$ & $\begin{array}{l}\text { Problemas relacionados à saúde, situação financeira } \\
\text { precária, falta de trabalho e moradia }\end{array}$ & $18,8 \%$ \\
\hline Violência Doméstica & $11,7 \%$ & Violência Doméstica & $10,3 \%$ \\
\hline $\begin{array}{l}\text { Dependência química } \\
\text { dos pais ou responsável }\end{array}$ & $11,4 \%$ & $\begin{array}{l}\text { Uso de drogas e álcool por parte dos pais ou } \\
\text { responsáveis }\end{array}$ & $9,8 \%$ \\
\hline
\end{tabular}

A institucionalização por pobreza ou situação financeira precária configura-se como o segundo motivo mais frequente. Portanto, apesar do abrigo se configurar como "uma possibilidade, um direito de todas as crianças e adolescentes que dele necessitem, independente de sua origem socioeconômica" (FROMER, 2002:312) a realidade nos mostra algo bem diferente.

Winnicott (1971/1975) já havia salientado que a pobreza nem sempre é sinônimo de falhas no cuidado e aponta que: 
(...)para um bebê ou criança pequena, uma família pobre pode ser mais segura e 'melhor' como meio ambiente facilitante do que uma família numa casa encantadora, onde haja ausência de perseguições comuns. [sentido esclarecido numa nota de rodapé: que enumera tais perseguições: "A superpopulação, a inanição, os insetos, a ameaça constante por parte da doença física, da calamidade e das leis promulgadas por uma sociedade 'benevolente'”]. (WINNICOTT, 1971/1975:192).

Esta questão é de fato complexa, pois, muitas vezes, a falta de recursos materiais é acompanhada por violações dos direitos das crianças e adolescentes, por exemplo, o abandono e a negligência. Através destes dados, é possível observar que, o motivo do acolhimento está relacionado a questões de políticas públicas que atendam as necessidades da população.

\footnotetext{
"Políticas de maior amplitude, direcionadas à habitação, à saúde, à educação e ao trabalho, certamente concorreriam para que grande parte destas crianças e adolescentes permanecesse com seus familiares. As pesquisas reafirmam o jargão: Não são crianças abandonadas, mas famílias abandonadas..." (OLIVEIRA, R.C., 2006:42).
}

A pesquisa denominada "Por uma política de abrigos em defesa de direitos das crianças e dos adolescentes na cidade de São Paulo" (AASPTJ-SP; NCA-PUCSP; SAS; FUNDAÇÃO ORSA, 2003) verificou a existência, em 2003, de 190 abrigos no município de São Paulo, sendo 4.847 o número de crianças e adolescentes atendidos. Além de abrigos, esta pesquisa investigou instituições de acolhimento especializadas no atendimento de portadores de deficiência mental e HIV; e aquelas que funcionam nos moldes de "colégio interno": que oferecem um acolhimento semanal, prevendo o regresso à família aos finais de semana. Ou seja, foram analisadas aquelas instituições onde há um afastamento concreto da criança ou adolescente de sua família, mesmo que este seja parcial.

A distribuição pela cidade não é homogênea: $32 \%$ encontra-se na zona sul; $29 \%$ na zona leste; $18 \%$ na zona oeste, $14 \%$ na zona norte e $7 \%$ na região central. A pesquisa ressalta que a concentração dos abrigos está diretamente relacionada às regiões de maior vulnerabilidade social. 
A proposta do atendimento personalizado e em pequenos grupos (BRASIL, 1990/2005:36 art. 92) tem como objetivo reproduzir um cotidiano similar a um ambiente familiar e residencial, sem, no entanto, ter a pretensão de substituir a família ou imitá-la como afirma R.C.OLIVEIRA (2006). Para a concretização deste princípio deve-se considerar o número de crianças e adolescentes atendidos, a possibilidade de um relacionamento contínuo entre os abrigados e os funcionários que cuidam deles e o plano de trabalho. A totalidade das instituições conveniadas à SAS atende entre 15 e 30 crianças. Em relação àqueles conveniados a Secretaria de Desenvolvimento Social (SEADS), a distribuição é mais heterogênea; 29,2\% atendem entre 21 e 40 crianças e adolescentes, enquanto $33,3 \%$ atendem entre 48 e 150 crianças. Mesmo aquelas instituições que acolhem entre 15 e 30 crianças levantam a questão do quanto é possível oferecer um atendimento personalizado para este número de crianças. Em relação a estas unidades maiores, a pesquisa ressalta que são de dois tipos: os colégios internos e grandes complexos do passado que foram desmembrados em pequenas casas que ocupam o mesmo terreno.

Em São Paulo, a maior parte das crianças e adolescentes é encaminhada pela Vara da Infância e Juventude (34\%) seguido pelo Conselho Tutelar (26\%). A própria família é responsável pelo encaminhamento de 10\% dos casos (AASPTJ-SP; NCA-PUC-SP; SAS; FUNDAÇÃO ORSA, 2003).

A respeito dos abrigados, a pesquisa do IPEA contabilizou quase 20 mil crianças e adolescentes moradores de casas abrigo (IPEA, 2003). A maioria é constituída por meninos (58,5\%), afrodescendentes (63\%) e com idade entre 7 e 15 anos (61\%). Nos abrigos paulistanos, $44 \%$ dos meninos e meninas são brancos, $37 \%$ pardos e $15 \%$ negros (AASPTJ-SP; NCA-PUC-SP; SAS; FUNDAÇÃO ORSA, 2003).

Desta população, 52,6\% estava institucionalizada há mais de dois anos, e entre elas, 32,9\% morava em abrigos havia entre 2 e 5 anos, $13,3 \%$ entre 6 e 10 anos e $6,4 \%$ por um período superior a 10 anos (IPEA, 2003). Apesar de não constar no ECA nenhum dado explícito acerca do tempo máximo que uma criança ou adolescente deve permanecer abrigado, é cada vez mais disseminada a noção 
de que o acolhimento não deve se estender por muito tempo, uma vez que o desenvolvimento no seio familiar deve ser prioridade.

\begin{abstract}
Podemos compreender o descompasso entre a consciência da necessidade do abrigamento pelo menor tempo possível e sua real efetivação, se levarmos em conta que, motivado pelas condições socioeconômicas precárias, o abrigamento se prolonga devido à falta de programas que favoreçam a reintegração familiar.

Assim, ao ocupar o espaço deixado pela insuficiência de programas que atendam a todas as famílias em situação de vulnerabilidade social, o próprio abrigo acaba se tornando uma forma de política pública, sendo, em geral, valorizado pelas famílias por proporcionar os estudos, os cursos, a disciplina, o lazer e o atendimento médico dos quais seus filhos estavam excluídos. (OLIVEIRA, 2006:44).
\end{abstract}

A morosidade no processo legal e na instalação de políticas públicas causa o que Pereira $^{5}$ (2003, apud MARTINEZ, 2006:53) denominou de violência institucional e que contribui para a construção de um lugar específico ocupado por tantas crianças e adolescentes: o da criança esquecida.

Dentre as crianças e adolescentes abrigados no Estado de São Paulo, 67\% possui família, 56\% está abrigado com irmãos, 66\% recebem visitas de familiares, $8 \%$ das famílias estão proibidas judicialmente de realizar visitas, $10 \%$ estão em situação legal que permite a adoção, 57\% não tem perspectiva de desacolhimento, exatamente pelo fato de a maioria não ter possibilidade de retornar à família (AASPTJ-SP; NCA-PUC-SP; SAS; FUNDAÇÃO ORSA, 2003).

Uma das características mais marcantes numa casa abrigo é a heterogeneidade. Lá, habitam crianças e adolescentes vindos de diversos contextos, abrigados por diversos motivos e com as perspectivas mais variadas - todas aguardando o retorno à família de origem, a inserção numa família substituta ou decisões judiciais que determinarão seu futuro (SERRANO, 2008). Esse acolhimento não especializado no que concerne ao sexo, idade, motivo de internação etc. abarca 85,9\% dos abrigos pesquisados pelo IPEA (2003) e segundo Glens (2010) é de extrema importância para evitar qualquer tipo de segregação. O autor ressalta ainda

\footnotetext{
${ }^{5}$ PEREIRA, J.M.F. A adoção tardia frente aos desafios na garantia do direito à convivência familiar. 2003. Dissertação (Mestrado em Psicologia). Instituto de Psicologia, Universidade de Brasília. 2203.
} 
que a criação do abrigo como espaço de diversidade é algo ousado e de difícil realização. Há implícitas restrições relacionadas, por exemplo, ao acolhimento de usuários de drogas, crianças e adolescentes com vivência de rua e portadoras de doenças graves (GLENS, 2010). Estas informações são confirmadas pela pesquisa "Por uma política de abrigos em defesa de direitos das crianças e dos adolescentes na cidade de São Paulo" (AASPTJ-SP; NCA-PUC-SP; SAS; FUNDAÇÃO ORSA, 2003) na qual observa-se que $57 \%$ dos abrigos pesquisados têm restrições ao admitir crianças e adolescentes que façam uso de drogas, 26\% que não tenha boas condições de saúde e 17\% que possua vivência de rua. Ainda persiste a ideia de que "uma laranja podre, estraga todo o cesto", porém Glens (2010) ressalta: "Se esse 'contágio' negativo pode, de fato, ocorrer, costuma-se esquecer que o oposto também é verdadeiro (as influências positivas) e é o que deve ser buscado" (p. 73).

Não são apenas as crianças e adolescentes que conferem uma tônica heterogênea aos abrigos. O quadro de funcionários também colabora para esse mosaico. De acordo com a pesquisa: "Por uma política de abrigos em defesa de direitos das crianças e dos adolescentes na cidade de São Paulo" (AASPTJ-SP; NCA-PUC-SP; SAS; FUNDAÇÃO ORSA, 2003), metade dos abrigos pesquisados não possuem assistentes sociais, psicólogos, pedagogos ou médicos. As justificativas para estas diferenças são variadas. Entre elas, encontramos: a alegação de que as instituições não oferecem um atendimento especializado; não possuem condição financeira para a contratação; consideram desnecessário os trabalhos destes profissionais, pois preferiram dar ao abrigo uma feição de casa.

O Ministério do Desenvolvimento Social e Combate à Fome em parceria com a Fundação Oswaldo Cruz (SNAS/MDS; FIOCRUZ, 2010) vem realizando uma pesquisa importantíssima desde 2009 cujos objetivos são: identificar e caracterizar a rede de serviços de acolhimento para crianças e adolescentes existentes em todo o Brasil; visitar todas estas instituições, realizando a identificação e a caracterização do serviço e das crianças e adolescentes neles atendidos. Até o momento, a pesquisa abrangeu 1.000 municípios das cinco regiões do país. Os dados preliminares identificaram 2.400 abrigos (com e sem auxílio governamental), dos quais 1.074 localizam-se na região sudeste. Estima-se que haja 54.000 crianças e adolescentes acolhidos em todo o Brasil. Esta estimativa traz à tona uma parcela 
considerável da população de crianças e adolescentes que se encontram em instituições de acolhimento e que demandam estudos específicos e o desenvolvimento de políticas públicas adequadas para que os preceitos do ECA possam ser efetivados.

\section{4. $O$ cuidador e o trabalho direto com crianças e adolescentes abrigados}

A denominação que designa os funcionários que trabalham direta $\mathrm{e}$ cotidianamente com crianças e adolescentes em casas abrigo pode variar. Entre as mais comuns, encontramos: educador (49\%); mãe ou pai social (16\%) e monitor (6\%). (AASPTJ-SP; NCA-PUC-SP; SAS; FUNDAÇÃO ORSA, 2003). Neste trabalho, optou-se por acrescentar mais um termo: cuidador, por considerar que expressa de forma ampla a função que desempenham ao lado destas crianças e adolescentes.

Das três pesquisas utilizadas para contextualizar a instituição abrigo no Brasil, apenas uma trata da questão dos funcionários que trabalham diretamente com as crianças e adolescentes e ainda assim apresenta poucos dados sobre este tópico. A pesquisa "Por uma política de abrigos em defesa de direitos das crianças e dos adolescentes da cidade de São Paulo" (AASPTJ-SP; NCA-PUC-SP; SAS; FUNDAÇÃO ORSA, 2003), traça um perfil de tais profissionais:

- Quanto à escolarização, $58 \%$ apresentam ensino médio completo; $19 \%$ ensino fundamental completo, $5 \%$ ensino superior completo. Embora a maioria possua ensino médio, o grau de escolaridade requerido para o cargo não é padronizado. A pesquisa aponta que muitos desses funcionários são registrados em carteira de trabalho ocupando funções operacionais para reduzir a folha de pagamento.

- $48 \%$ trabalha em turnos de plantão 12/36 horas. Essa questão problematiza a complexidade do trabalho. Ao mesmo tempo em que preconiza uma estrutura familiar e doméstica, conta com a descontinuidade constante dos vínculos.

- Em contrapartida, $20 \%$ dos cuidadores moram na instituição. Este modelo, apesar de garantir a estabilidade das figuras de referência 
acrescenta outros problemas para a questão, que precisam de maiores estudos, como as dificuldades oriundas do afastamento em caso de retorno à família de origem ou inserção em família substituta.

A pesquisa ressalta, a partir de entrevistas realizadas, que a função tanto dos cuidadores como dos profissionais de nível superior (assistentes sociais, psicólogos etc.) não estão claras:

O educador seria o profissional com função relacionada aos cuidados diretos que envolvem o processo socioeducativo da criança ou do adolescente, (orientar brincadeiras, normas de convivência, acompanhá-los nas atividades, etc.).

O funcionário que assume as atividades rotineiras do abrigo, como lavar, cozinhar, arrumar, embora possa intervir na educação da população abrigada, nem sempre tem autorização para assumir o papel explícito de educador.

O trabalho preponderante do profissional graduado está voltado para a reinserção da criança e do adolescente no ambiente familiar, por meio, sobretudo, do levantamento de seu histórico de vida, do acompanhamento das crianças, dos adolescentes e de seus familiares, da orientação, do encaminhamento a atendimentos específicos, da elaboração de relatórios para o Juizado etc. (AASPTJ-SP; NCA-PUC-SP; SAS; FUNDAÇÃO ORSA, 2003:134).

Os profissionais de nível superior chamados de técnicos, historicamente, tiveram suas funções associadas à equipe dirigente na manutenção da ordem e da disciplina, transformando-se em agentes de controle social através da "psicologização" e medicalização (GALHEIGO, 2003). Atualmente, a opção por se trazer profissionais técnicos para atuarem junto à população de crianças e adolescentes abrigados assume um caráter emancipatório. O trabalho se desenvolveria na superação de conflitos e de visões preconceituosas em torno da população atendida. Além disso, seria fundamental desenvolver um trabalho de atenção que contemple ações territoriais, institucionais, familiares, grupais e individuais (GALHEIGO, 2003). A autora ainda problematiza o quanto pode ser difícil ter uma equipe interdisciplinar trabalhando em cada instituição devido aos custos de contratação. Sugere que houvesse equipes municipais itinerantes, que pudessem oferecer supervisão institucional e constituir-se como uma referência. 
Em termos psicodinâmicos, o papel do cuidador pode ser compreendido a partir dos aportes de Winnicott e Bowlby. Uma vez afastada de suas figuras parentais, a criança precisa da assistência de outro adulto. Bowlby (1997) salienta o quanto é fundamental a existência de alguém que atue como substituto no cuidado e a quem a criança possa se ligar gradualmente e estabelecer laços de confiança e afeto.

Nestes primeiros vínculos, a relação consanguínea não é determinante e sim a satisfação de determinadas condições que caberia, segundo Winnicott (1988/2006), a quem desenvolva o papel da mãe suficientemente boa, que não implica, necessariamente, na mãe biológica. Sendo assim, outras pessoas podem assumir este papel. No caso dos abrigos, monitores, cozinheiras, diretores e outros técnicos constituem parte fundamental para a transformação do espaço num ambiente acolhedor material e afetivamente (DOTTORI et al., 2008).

Os educadores que atuam diretamente junto às crianças e adolescentes garantem a satisfação das necessidades básicas. Necessidades estas relacionadas: à segurança, crescimento e sobrevivência; ao desenvolvimento emocional; ao desenvolvimento social; ao desenvolvimento cognitivo e linguístico (Amorós e Palácios $^{6}, 2004$ apud SERRANO, 2008). Gulassa (2006) afirma que o educador precisa realizar seu trabalho a partir da construção de um vínculo com a criança, num relacionamento de confiança e afetividade. Oliveira (2006) destaca em seu mestrado a importância de um convício afetuoso entre abrigados e seus cuidadores que podem até mesmo desempenhar uma função materna ou paterna.

Estas crianças e adolescentes possuem um ambiente anterior ao abrigo (em alguns casos, mais de um: além da família de origem, podemos contar outros abrigos e famílias substitutas que não se adaptaram). Estes ambientes, por um motivo ou por outro, falharam ao suprir as necessidades físicas e/ou psicológicas e a relação com adultos cuidadores anteriores ao abrigo influenciam o relacionamento de crianças e adolescentes e os educadores da instituição (OLIVEIRA, 2006: 170). Isso acrescenta um complicador às relações entre as crianças e adolescentes e seus cuidadores no abrigo. Esta história de vida marcada pelo rompimento de

\footnotetext{
${ }^{6}$ AMORÓS, P.; PALACIOS, J. Los protagonistas y lós factores clave en el acogimiento familiar. In. Acogimiento familiar. Madrid: Alianza,
} 2004. 
vínculos se reflete, frequentemente, na grande demanda por atenção e cuidados que, muitas vezes, além de não ser correspondida é vista como indisciplina (RIZZINI \& RIZZINI, 2004). À equipe do abrigo compete o desafio de recebê-los,

\begin{abstract}
“(...) criando condições para que possam expressar seus conteúdos emocionais completivos, ambivalentes, sentindo-se acolhidos em um ambiente estável, seguro, com adultos responsáveis que não se desorganizam diante de ataques hostis ou de movimentos manipulatórios e de sedução, o que significa que a criança ou adolescente possam viver/compreender essa experiência - o abrigo - como proteção e cuidado, quer seja uma medida provisória ou de longa duração." (FROMER, 2002:314).
\end{abstract}

Devido às vivências conflituosas com seus familiares, as crianças e adolescentes abrigados se relacionam muitas vezes com extrema desconfiança em relação a qualquer adulto que desempenhe uma função de cuidado e educação. O educador deve oferecer exatamente o oposto do que os jovens estão acostumados: a estabilidade de vínculo, que será constantemente testada (GLENS, 2010). Em outras palavras, Winnicott (1987/1999) afirma que crianças afastadas de seus lares têm uma tendência a idealizá-los e podem se tornar muito hostis em relação ao novo lar e aos novos cuidadores. O autor destaca que é mais saudável que estes cuidadores substitutos possam absorver as ondas periódicas de sentimento negativo e sobreviver a elas, construindo então uma relação nova e mais segura com a criança.

Winnicott (1987/1999) reforça que a assistência a crianças é um processo de tempo integral e esvazia as reservas emocionais dessas pessoas que realizam o trabalho de cuidar delas. Martinez (2006) ressalta a fala de uma educadora acerca de sua função:

"O trabalho aqui no Lar é muito bom, mas exige muito da gente. Tem que gostar muito de criança porque elas ficam se dependurando toda hora em você. São muito carentes, né?" (MARTINEZ, 2006:115). 
Careta (2006) expõe o quanto as educadoras do abrigo onde acompanhou dois irmãos abrigados apresentavam-se frágeis, invadidas pela privação, identificadas maciçamente com o abandono e com as condições de acolhimento institucional. E a partir do trabalho apresentado no mestrado percebeu que não bastava cuidar das crianças e adolescentes acolhidos. Concluiu que o ambiente (termo que também abrange os educadores) merece cuidados para que o desenvolvimento daqueles que dependem deste meio possa se dar naturalmente, pela ação de suas tendências inatas. E uma maneira de cuidar deste ambiente seria o uso de enquadres diferenciados com educadores como medida preventiva e não somente curativa.

Kaës (2011) abordará as dificuldades com a clínica direta em instituições cuidadoras. Isto porque, os profissionais que nela trabalham são exigidos para:

\footnotetext{
"conter experiências emocionais extremas, para abrigar fantasmas duros e violentos que produzem arrombamentos de suas paraexcitações, curtos circuitos de seu 'aparelho de pensar os pensamentos' (Bion), aturdimentos interativos, de valor, às vezes, propriamente traumático" (p. 23).
}

Esse confronto acaba minando os processos de pensamento, de elaboração grupal e a criatividade individual e coletiva. Consequentemente lidar com os chamados "casos difíceis" pode representar para os funcionários atuantes no cuidado uma ameaça de fracasso das funções cuidadoras, que abala o narcisismo do grupo cuidador. E isto, para Kaës (2011), consiste numa fonte essencial de pedido de intervenção a um terceiro, externo à instituição.

Durante o período de guerra, Winnicott (1987/1999) acompanhou a experiência de crianças evacuadas e mandadas para lares substitutos. No capítulo intitulado: Tratamento em regime residencial para crianças difíceis, o autor trata, entre outros assuntos, do treinamento para os profissionais que atuarão diretamente com tais crianças. Afirma que é impossível generalizar o tipo de pessoa mais adequado para esta tarefa. 
Achamos que a natureza do treinamento e da experiência anteriores tem menos importância do que a capacidade para assimilar experiências e para lidar de modo autêntico e espontâneo com os acontecimentos e as relações. Este aspecto é extremamente importante, pois somente aqueles que são suficientemente confiantes para serem eles mesmos, e para agirem de um modo natural, podem atuar coerentemente todos os dias. Além disso, os supervisores são submetidos a uma prova tão severa pelas crianças, que só os que são capazes de serem eles mesmos conseguem suportar a tensão. (WINNICOTT, 1987/1999:76).

Winnicott (1987/1999) considerava inúteis aqueles supervisores a quem tudo devia ser prescrito e seguido, pois as coisas mais fundamentais podem acontecer em cima da hora, de forma imprevisível, e por isso é importante a autenticidade e naturalidade do funcionário. A respeito disso, escreve:

Não é possível fazer a coisa certa por uma criança promulgando uma lei ou instalando uma engrenagem administrativa. Essas coisas são necessárias, mas constituem apenas um primeiro e melancólico estágio. Em todos os casos, um tratamento apropriado de uma criança envolve seres humanos [grifo do autor], e esses seres humanos têm que ser do tipo certo (...). (WINNICOTT, 1987/1999:201).

Oliveira (2006) em sua dissertação de mestrado desenvolvida na Universidade Federal do Rio Grande do Sul, ressalta o embate entre os cuidados mecanizados e mais humanizados. A autora identificou dificuldades nas duas instituições investigadas acerca de uma posição distanciada destinada a controlar e monitorar a vida dos abrigados. Os educadores capazes de estabelecer um vínculo mais afetuoso, eram os que aceitavam a criança ou adolescente na sua singularidade, acolhendo suas histórias de dor e ressignificando experiências anteriores. A autora aponta as relações afetivas como o meio para que os abrigados consigam dar sentido a sua história de vida e ao desenvolvimento da esperança no futuro.

Em muitas instituições, a falta de preparo da equipe leva ao estabelecimento de regras tão rígidas de conduta que impedem uma vivência autêntica e criativa do cotidiano e, mais ainda, podem levar crianças e adolescentes a perderem suas identidades (Arpini, 2003). Considera-se que desta forma, crescem num ambiente marcado pela despersonalização, impessoalidade, inexistência de vínculos 
significativos, reproduzindo, assim, a lógica da exclusão e do abandono. Dottori et al. (2008) afirmam a importância de se selecionar pessoas preocupadas que possam se envolver emocionalmente com as crianças e adolescentes e que se sintam comprometidas com a vida.

Em artigo, Berger e Gracino (2005) desenvolveram uma pesquisa que buscou investigar o papel do educador junto a um grupo constituído por dezesseis funcionários de um abrigo. Durante os encontros (quinzenais), as pesquisadoras destacaram certos termos constantemente reiterados no discurso dos funcionários quanto ao papel que desempenhavam no abrigo, tais como: presença, esperança e futuro. Cada educador deveria preencher fichas sobre os abrigados e para surpresa das pesquisadoras, tais fichas serviram não só como instrumentos de hetero conhecimento (educador-abrigado), mas de autoconhecimento (educador consigo mesmo). Esse simples procedimento despertou uma ampliação de consciência acerca do papel que exerciam junto às crianças e adolescentes, caracterizado principalmente por seu caráter mediador tanto no sentido de uma transmissão cultural, quanto em relação às perspectivas de futuro.

Ao analisar também o discurso de funcionários e educadores de um abrigo, Dottori et al. (2008) destacaram falas carregadas de afetos positivos em relação aos abrigados. Porém, apontam a falta de apoio, supervisão ou capacitação, o que as pesquisadoras relacionam com o prejuízo ao desenvolver um trabalho mais comprometido e um enfraquecimento do vínculo. O diálogo dos educadores com os abrigados é confundido com permissividade ou autoritarismo que, do ponto de vista das pesquisadoras, poderia ser amenizado com a existência de um espaço de referência para o próprio funcionário. Sobre isso, as autoras afirmam:

\footnotetext{
Assim como para os meninos, é perpetuada para os funcionários a condição de falta de voz e de poder de transformar a situação. Como proteção e defesa, os cuidadores muitas vezes ficam insensíveis à realidade vivida e desesperançosos quanto ao alcance de seu trabalho. (DOTTORI et al., 2008:281).
}

Oliveira (2006) em sua dissertação de mestrado aborda esta mesma ambivalência entre a permissividade e o autoritarismo. Nas instituições onde realizou 
sua pesquisa, observou esta dualidade expressa em dois momentos: num primeiro, o educador age com permissividade para 'conhecer' a criança ou adolescente, e num segundo instante adota medidas autoritárias para disciplinar os abrigados. A autora salienta, através de entrevistas com adolescentes abrigados, que o resultado desta postura é o afastamento do adolescente. Aborda, ainda, a adoção de um comportamento de enfrentamento dos adolescentes diante de medidas disciplinadoras muito rígidas.

Parente, Leoncio e Tardivo (2008) apontam outro aspecto importante na relação entre cuidadores de abrigo e as crianças abrigadas. Assim como Careta (2011), abordam a intensa identificação entre os educadores e as crianças e acrescentam a dificuldade de se separar destas. Parente, Leoncio e Tardivo (2008) discutem a questão a partir do exemplo de uma educadora que percebia as crianças abrigadas como abandonadas, sem cuidados nem recursos internos. Ao passo que via na manutenção das crianças no abrigo uma chance para poder cuidar, do contrário sentia que cometera algum erro. Desta forma, dificultava o vínculo entre as crianças e os pais biológicos, demonstrando uma solicitude compulsiva que era respondida pelas crianças por uma gratidão permeada pela culpa.

Além da identificação com aspectos mal integrados, pode ocorrer o outro movimento. Oliveira (2006:168) aponta o quanto um educador pode servir como modelo para um adolescente abrigado. No entanto, salienta a necessidade do cuidador superar "o mal estar institucional e preconceitos decorrentes dos papéis anteriormente estabelecidos - onde o adolescente abrigado é sinônimo de má índole, desestruturado e com poucas possibilidades de reconstrução de vida" ( $p$. 168). Desta forma é possível estabelecer outro tipo de relação com os abrigados, se constituindo como uma figura de referência.

Todos estes dados apontam para a complexidade da função de educador numa casa abrigo. A tarefa que desempenham implica numa doação emocional muito intensa para as quais, nem sempre, estão preparados. A falta de um trabalho de acolhimento para estes cuidadores torna estas questões mais exacerbadas. Elas acabam repercutindo no relacionamento com as crianças e adolescentes abrigados, prejudicando ainda mais seu desenvolvimento marcado por perdas, instabilidades de vínculos e rompimentos. 


\section{Aspectos psicológicos da institucionalização}

Muitos estudos foram realizados nos quais são discutidos os efeitos da institucionalização em crianças e adolescentes. A seguir, citaremos diversos trabalhos realizados, sobretudo, em nosso meio e que discutem aspectos e consequências da institucionalização, mostrando-se até contraditórios entre si. Os estudos apresentados não dão conta de todo o material produzido na área, mas revelam a complexidade do tema.

Barros et al. (2007) realizaram um levantamento de pesquisas que estudaram o rompimento de vínculo afetivo em crianças abrigadas à luz da Teoria do Apego desenvolvida por Bowlby (1985). Nos trabalhos estudados, os autores assinalam diversos prejuízos em crianças com história de ruptura de vínculos (comprometimentos físicos, cognitivos, sociais e emocionais; dificuldades de estabelecer relações de apego seguro; comportamento indiscriminado), mas divergem quanto à reversibilidade ou não das consequências. São, portanto, divididos em dois grandes grupos: os "deterministas" - mais pessimistas em relação ao prognóstico; e os "contextualistas" - que apontam para as possibilidades de reconstrução dos vínculos a partir de aspectos que envolvem o meio ambiente, as redes de apoio social e os recursos internos da própria criança. Barros et al. (2007) concluem que medidas que visem à minimização dos riscos e à garantia do bem estar da criança ou adolescente em uma nova situação - seja no regresso à família de origem, na família substituta ou no abrigo - são fundamentais: incluindo o acompanhamento das famílias; a implantação de uma política de reestruturação dos abrigos; maior intercâmbio entre o abrigo, o Conselho Tutelar e o Poder Judiciário; bem como o aprimoramento de políticas públicas voltadas para a criança, o adolescente e à família como prioridade absoluta (grifo dos autores).

Em seu estudo, Dell'Aglio (2000) investigou diversos aspectos no desenvolvimento de crianças e adolescentes que viviam em abrigos (nível intelectual, desempenho escolar, estratégias de coping e estilo atribuicional). De todas as variáveis, a única significante, comparada a crianças e adolescentes que viviam com a família, foi o índice de depressão, que se mostrou mais alto em meninas institucionalizadas. A própria autora interpreta que estes resultados não indicam uma relação causal entre a institucionalização e a depressão. Ressalta que, 
na maioria dos casos, a institucionalização se deu em consequência de eventos traumáticos na família (abandono, violência doméstica, negligência), podendo ter sido este o principal fator de risco para a depressão. Além disso, a autora também aponta que, para muitos dos participantes de seu estudo, a institucionalização foi percebida como um evento de vida positivo.

Relacionando-se ao trabalho de Dell'Aglio (2000), Abreu (2000) investigou a prevalência de transtornos psiquiátricos em 63 crianças institucionalizadas comparadas a um grupo controle composto por outras 63 crianças. Como resultados, obteve um índice maior de incidência de transtornos em crianças abrigadas $(49,2 \%$ e $14,3 \%$ no grupo controle), sendo que a depressão foi o transtorno mais frequente $(28,6 \%$ e $7,9 \%$ no controle). Conclui que crianças e adolescentes institucionalizados têm maior chance de apresentar transtornos psiquiátricos quando comparados àqueles que vivem com suas famílias. Semelhante a Dell'Aglio (2000), a própria autora ressalta a dificuldade de diferenciar a causa destes transtornos: a vivência traumática familiar ou vida institucionalizada.

Leoncio (2003) realizou entrevistas e aplicação do Procedimento de Desenho Estória com 13 crianças e adolescentes abrigados. A partir deste material chegou à conclusão de que a ida para o abrigo intensificou problemas emocionais destas crianças e adolescentes que, ao se verem separadas da família, expuseram sentimentos de desamparo, abandono, rejeição, desproteção e solidão. O sofrimento era intensificado pela percepção do abrigo como punição por não se comportarem bem, o que trazia muitos sentimentos de culpa. Leoncio (2003) ressalta o quanto a vivência de uma criança recém-abrigada pode ser de sofrimento e esperança: sofrimento por todas as privações que viveram e esperança de que possam vir a receber algo de bom para torná-las mais felizes. A ambivalência também foi destacada por Luz et al. (2011). Ao utilizarem o procedimento de desenho estória com tema, apreenderam na produção de quatro crianças entre 8 e 10 anos o conflito entre o caráter protetor e ao mesmo tempo aprisionador da instituição.

Ainda sobre esta questão, Passarini, Colacique, Tardivo (2012) aplicaram o procedimento do Desenho Estória com tema em um grupo de adolescentes abrigadas com seus filhos. Nas estórias elaboradas a partir das produções gráficas e na conversa subsequente, surgem queixas em relação às educadoras "que pegam 
no pé" (sic), à falta de liberdade para saírem sozinhas e a falta de condições financeiras para comprarem roupas e satisfazer outros desejos. Localizam a relação com alguns funcionários também como muito ruim devido ao tratamento bruto, preconceituoso e a demonstração de preferência por algumas meninas em detrimento de outras. Mas também há o reconhecimento do abrigo como um local em que são ajudadas a como serem mães, um local de amizade, orientação e compreensão.

Os conflitos com a equipe de educadores do abrigo também surge no estudo de caso apresentado por Castro, Colacique e Tardivo (2012) A paciente de 15 anos atendida em psicoterapia relata sua hostilidade em relação à equipe de profissionais da instituição, questionando inclusive suas funções e competências profissionais. Queixa-se de diversos procedimentos no trato com os abrigados, inclusive um caderno de anotações (espécie de caderno ata onde os principais acontecimentos diários são anotados) que a adolescente julga expor as crianças e adolescentes

Apesar de todos os conflitos que possam ocorrer, Careta (2006) e Rotondaro (2005) acreditam que as crianças consigam desenvolver vínculos saudáveis nos abrigos. Isso se daria em consequência de aspetos internos preservados das crianças e adolescentes que podem ser desenvolvidos no período de institucionalização. Esses autores ressaltam a importância do trabalho junto à equipe de cuidadores para que compreendam melhor o processo de cuidado destas crianças que podem permanecer no abrigo por muitos anos.

Ainda que exista a possibilidade de se estabelecer vínculos saudáveis numa instituição de acolhimento, o rompimento do vínculo afetivo com os pais, ainda que conturbados, trazem sequelas sociais e emocionais de acordo com Dell'Aglio e Hutz (2004). Esses efeitos se relacionam ao fato de, nos abrigos, os relacionamentos serem mais impessoais e menos significativos, quando comparados aos que poderiam ser desenvolvidos em família. Ou autores relacionam este ponto ao caráter temporário e transitório do abrigo. Ainda, enfatizam o quanto a institucionalização pode acarretar num autoconceito negativo devido ao estigma institucional.

Outra consequência é o que Parreira e Justo (2005) chamaram de "desfiliação". Quando a criança é afastada da família, aparta-se dela também o 
contato com a sua origem, história e dos legados de seus antepassados. A transitoriedade que desperta o acolhimento levanta a questão da fragmentação de referenciais para a definição da identidade e de vínculos afetivos duradouros.

Em trabalho etnográfico realizado em um abrigo, Barros e Fiamenghi Jr. (2007) notaram que crianças em torno de um ano recebiam pouca estimulação das educadoras. Aquelas crianças que não andavam ou engatinhavam, permaneciam todo o dia sentadas e quando tentavam se levantar eram repreendidas e novamente colocadas na posição sentada. A relação entre as crianças e adolescentes junto a seus cuidadores era marcada pelo autoritarismo. A violência e agressividade das quais deveriam ser protegidas, acabavam por permear os vínculos institucionais.

Careta e Motta (2009a) em seu trabalho afirmam não ser possível atestar que as crianças abrigadas não sofram prejuízos em seus desenvolvimentos em razão do distanciamento do lar. Porém, as autoras consideram que medidas interventivas possam minimizar tais danos.

Como exemplo do alcance de intervenções clínicas neste contexto, citamos alguns trabalhos a seguir. Leoncio e Tardivo (2007) abordam os efeitos integrativos de consultas terapêuticas realizadas com uma mãe e sua filha abrigada de três anos. O trabalho consistiu num acolhimento e maternagem por parte da terapeuta que ajudou ambas a reestabelecer um vínculo que havia sido rompido com o acolhimento e o posterior abandono da filha pela mãe que ficou 5 meses sem visitala.

Paschoaletti, Careta e Motta (2008) também trazem as contribuições do atendimento psicológico junto a uma mãe que teve seu filho abrigado por agredi-lo fisicamente. Ao longo das sessões, a mãe pode compreender esta agressividade, antes negada completamente a luz de suas próprias experiências de cuidado e maternagem. "Os atendimentos revelaram uma história de vida repleta de abandono familiar, agressões e um casamento cujos vínculos amorosos eram precários e turbulentos" (Paschoaletti, Careta e Motta, 2008:420). Chegam à conclusão de que o psicoterapeuta, ao oferecer holding à mãe e à família de crianças abrigadas, apresenta-se como um ambiente suficientemente bom, colaborando para o desenvolvimento da preocupação materna primária. 
O holding e o brincar foram as ferramentas apresentadas por Nakagawa, Careta e Motta (2008) no atendimento psicológico de um menino abrigado cuja queixa eram comportamentos agressivos. O terapeuta operou como uma figura facilitadora que proporcionou um espaço no qual o paciente pôde dar voz aos seus impulsos agressivos. Ao aceitar a proposta de brincadeiras nas quais a agressividade era conteúdo central, o terapeuta, proporcionou um encontro terapêutico genuíno que colaborou para a integração de aspectos agressivos como parte da personalidade do menino.

Silva, Colacique e Tardivo (2010) relatam o sofrimento psíquico vivido por uma adolescente abrigado cuja mãe adotiva morrera no dia do seu último aniversário de 13 anos havia 2 meses. Abordam a elaboração do luto por este menino, que já havia passado por muitas perdas como o abandono da mãe biológica e o afastamento das pessoas que amava. Concluem que a psicoterapia e o vínculo de confiança com a terapeuta conferiu condições acolhedoras para que ele vivesse este processo no seu ritmo.

Tironi, Colacique e Tardivo (2011) apresentam o relato de caso de uma menina abrigada de 8 anos cujo estado emocional inspirava atenção por parte da equipe da instituição. A menina fora abrigada por negligência parental e havia a suspeita de ter sofrido violência sexual. Não permitia a aproximação de nenhum educador do sexo masculino, apresentava enurese e ecoprese e um comportamento que oscilava entre a passividade e explosões agressivas. Quando frustrada, ficava paralisada sem esboçar nenhuma reação durante um tempo indeterminado. Sua família vivia nas ruas catando lixo. A menina e os irmãos passavam o dia no carrinho de mão junto ao lixo enquanto os pais estavam realizando a coleta. Durante as sessões lúdicas, a criança passava o tempo organizando os brinquedos, dizendo inclusive, como a terapeuta deveria brincar. As autoras apontam para a dificuldade do brincar espontâneo e ressaltam o quanto a menina não confiava no ambiente como provedor do que fosse necessário e precisava controlá-lo. Com o andar do tratamento, a menina pode ampliar a sua exploração no brincar, experimentando outras possibilidades que não exija o controle onipotente e o aumento da confiança no ambiente. A angústia vivida por esta criança é encarada pelas autoras como 
consequência das falhas no cuidado que vivenciou quando ainda estava com os pais.

Tafner, Colacique e Tardivo (2011) apresentam um caso de um menino abrigado de 11 anos atendido em psicoterapia e que estabeleceu uma comunicação integrativa com a terapeuta através do Jogo do Rabisco. Através deste recurso, o menino pôde integrar um aspecto fragmentado da sua vivência podendo expressar o quanto se sentira envergonhado por uma confusão que criou na instituição. As autoras ressaltam a disponibilidade da terapeuta em aceitar o jogo e o fazer criativo do paciente.

Mostra-se muito complicado discernir entre as sequelas psicológicas oriundas da falha no cuidado ainda no ambiente familiar e a experiência de institucionalização. Takushi, Leoncio e Tardivo (2008) relatam um caso onde a privação anterior ao acolhimento fica patente. O paciente em questão possuía doze anos, tendo sido abrigado aos três devido a denúncias de negligência: era frequentemente internado por pneumonia, tinha fraqueza nos membros inferiores devido à estimulação insuficiente e uma alergia generalizada pelo corpo todo. Aos doze anos, era descrito como uma criança passiva, frágil, com comprometimento emocional e atraso no desenvolvimento. Este caso se presta à discussão do quanto é complexa a relação entre o que causou o afastamento da família e a privação dos pais em si. As autoras problematizam o quanto a família não forneceu os cuidados necessários para que o menino desenvolvesse ao máximo suas capacidades e ao mesmo tempo, o quanto este abrigo não se constituiu como um ambiente favorável em termos de cuidados contínuos e amorosos.

Por outro lado, Careta e Motta (2008c) trazem à tona uma discussão ética ao relatar condições de tratamento e desenvolvimento de um menino abrigado, na qual, a inadequação da instituição fica patente. Neste artigo, as autoras contam alguns encontros lúdicos com Pedro, um menino de quase 5 anos descrito pela assistente social da instituição como um caso perdido, usava fraldas, andou aos 3 anos, começara a falar havia pouco tempo, evacuava imediatamente em seguida de ingerir qualquer alimento, tinha os pés virados para dentro e chagas por todo o corpo (CARETA; MOTTA, 2008c:287). O menino tinha uma mãe alcoolista e ficara com ela até os sete meses. No dia marcado para iniciar seu trabalho, as pesquisadoras 
encontraram o espaço destinado à hora lúdica repleto por baratas mortas e Pedro estava amarrado num carrinho de bebê. Ficar amarrado no carrinho, além de tentar conter a agitação do menino, era usado, segundo a observação das pesquisadoras, como punição e ameaça. O carrinho era deixado num espaço vazio voltado para uma parede branca. Neste caso, independente das privações que o menino tenha vivido quando estava sob os cuidados da mãe, é inquestionável a falha ética do abrigo ao não suprir condições adequadas para que esta criança continuasse o seu desenvolvimento, provocando marcas psíquicas profundas. As pesquisadoras diante dessa situação extrema redigiram um relatório sobre as condições emocionais de Pedro e uma crítica contundente ao ato de amarrá-lo no carrinho além de outras situações de negligência vividas pelo menino na instituição. Além das promessas de melhoras do abrigo, no artigo não se sabe quais foram as providências efetivas tomadas.

Para problematizar este aspecto destacamos o trabalho de Siqueira e Dell'Aglio (2006) que apontam duas questões levantadas por Grusec e Lytton (1988 ${ }^{7}$ apud SIQUEIRA \& DELL'AGLIO, 2006) de fundamental importância na compreensão deste ponto: (1) os efeitos danosos advêm da privação, no abrigo, de estimulação necessária para o desenvolvimento ou da privação do cuidado materno? E ainda, (2) esses efeitos surgem do rompimento dos vínculos de apego ou de distúrbios das relações familiares? Concluem que muitos déficits intelectuais, observados em instituições de abrigo, podem ser devido a privações de algum tipo de estimulação sensorial, independente do cuidado materno.

De qualquer forma, mesmo em instituições de alta qualidade, a inteligência e autonomia de crianças deste contexto são marcadamente menores do que aquelas que foram cuidadas em suas casas (GRUSEC \& LYTTON, 1988 apud SIQUEIRA \& DELL'AGLIO, 2006). Isto sugere que a segurança emocional, derivada da existência de relações estáveis na vida da criança, pode contribuir para o funcionamento intelectual adequado. Quanto à segunda questão, muitos dos problemas de conduta de crianças abrigadas já estavam presentes antes da institucionalização. Isto aponta para os fatores de risco no ambiente familiar, onde as relações eram marcadamente instáveis, estressantes e conflituosas. Assim, estas experiências precoces 
demonstraram operar um papel importante no desenvolvimento posterior, e, desta forma, a separação em si não constituiu o fator decisivo (GRUSEC \& LYTTON, 1988 apud SIQUEIRA \& DELL'AGLIO, 2006).

Além das vivências anteriores ao acolhimento e as condições de cuidado encontradas na instituição, aspectos pessoais são importantes quando falamos dos efeitos psicológicos da condição de abrigado. Em artigo, Careta e Motta (2008a) abordam as diferenças entre dois irmãos gêmeos abrigados. As autoras debatem o papel de relações afetivas patológicas no contexto institucional, que podem ter exercido considerável influência no desenvolvimento dos dois irmãos. Enquanto um deles apresentava boa continência frente a angústias depressivas, o outro se desorganizava diante destes sentimentos. As autoras chegam à conclusão de que, mesmo diante das mesmas condições de acolhimento, os irmãos gêmeos apresentam aspectos saudáveis propulsores para a saúde, porém ressaltam a necessidade de assistência institucional com políticas públicas que possuam metas para o desenvolvimento de saúde mental voltadas para os funcionários do abrigo. A partir daí, foram realizados encontros terapêuticos com as educadoras. Através do uso de desenhos livres (CARETA, 2006; CARETA; MOTTA, 2007) e posteriormente de desenhos temáticos (CARETA; MOTTA, 2009; CARETA, 2011) as pesquisadoras procuram compreender aspectos psicopatológicos apresentados pelas educadoras. Os encontros terapêuticos mediados pelos desenhos possibilitaram que estas educadoras mudassem de posição: de uma identificação patológica, para uma maior diferenciação, o que levou a outra qualidade na atenção das necessidades das crianças e adolescentes (CARETA, 2011).

Assim como a chegada ao abrigo e o período de adaptação, o desacolhimento também surge como desencadeador de conflitos psíquicos. Apesar da permanência em instituições de acolhimento de crianças e adolescentes serem descritas no ECA como provisória e excepcional (BRASIL, 1990/2005, art. 101, parágrafo único) a realidade nos mostra ser comum a permanência por muitos anos na instituição. Este fato tem uma implicação direta nos conflitos que podem ser despertados acerca de um desligamento institucional gradual e saudável para aqueles que chegam à maioridade civil. 
Martinez (2006) levanta uma série de questionamentos para investigar o quanto adolescentes abrigados são capazes de construir maior autonomia e independência, preparando-se para o momento de desligamento do abrigo. A autora realiza entrevistas com dois adolescentes que estão prestes a serem desabrigados. A partir destes encontros, levanta aspectos importantes como: (1) a noção de gratidão em relação à instituição, que surge tanto pelo reconhecimento dos cuidados prestados como uma obrigação diante do investimento realizado durante o período de acolhimento. (2) A transformação do abrigo numa referência após a saída. As pessoas da instituição, muitas vezes, são aquelas que protegem, aconselham, apoiam e interditam ações. Manter o contato aplaca a angústia de "estar sozinho no mundo". (3) A saída do abrigo é encarada com sofrimento tanto por se ver afastado das figuras de referência como pela insegurança em relação às responsabilidades que virão. (4) A retomada do contato com a família biológica que, dependendo das circunstâncias, pode ser muito difícil. (5) A saída do abrigo entendida como ganho de maior liberdade e autonomia.

Silva, Leoncio e Tardivo (2007) dedicaram-se a relatar a experiência clínica vivida por um adolescente de 14 anos abrigado desde os dois anos de idade. A atenção se voltou para um atendimento que preparasse 0 rapaz para 0 desacolhimento que já sofrera uma tentativa frustrada quando tinha 11 anos e não se adaptou à família, tendo voltado ao abrigo. As autoras ressaltam a necessidade de um trabalho com a família a fim de potencializar a capacidade de cuidar deste rapaz.

Rentes e Tardivo (2012) apresentam um estudo de caso de uma menina abrigada. Gabriela (nome fictício) tinha 17 anos e estava abrigada havia 11 anos. Realizou um Desenho Estória com Tema (AIELLO-VAISBERG, 1997, 1999) em que representava três momentos da sua vida: o passado, o presente e o futuro. Estava prestes a sair da instituição e manifestava todo o carinho por duas amigas, pelos irmãos e funcionários do abrigo, dizendo que todos eles eram a sua família. $O$ sofrimento em deixar a instituição onde passara quase toda a vida é expressa no desenho que aborda o "depois do abrigo" onde se vê um caixão e flores.

Como é possível notar os diversos trabalhos apresentados apontam para inúmeras questões verdadeiramente complexas relacionadas à experiência 
psicológica do acolhimento institucional. O encaminhamento para uma instituição abrigo visa à proteção de crianças e adolescentes que provém de um ambiente familiar que não conseguiu desempenhar seu papel de maneira satisfatória. O afastamento das figuras parentais gera uma série de marcas nestas crianças e adolescentes. Por outro lado, a vida institucional também acarreta consequências, principalmente quando não se desempenha sua função de forma ética e comprometida. Assim, as intervenções psicoterapêuticas se configuram como uma medida voltada a atenuar os efeitos danosos e proporcionar uma maior integração do que foi vivido antes do abrigo e as experiências específicas da institucionalização. Neste contexto, as oficinas terapêuticas podem se configurar como estratégias interessantes de trabalho junto à população de crianças e adolescentes abrigados bem como ao corpo de funcionários da instituição.

\section{OFICINAS TERAPÊUTICAS}

A seguir, abordaremos de forma sucinta o arcabouço teórico que fundamenta a prática das oficinas terapêuticas entendidas como expressão dos enquadres diferenciados de inspiração winnicottiana. Para isso, nos deteremos, principalmente, em autores como Bleger, Winnicott e Aiello-Vaisberg.

\section{Fundamentos}

Em um texto intitulado "Psicanálise do enquadramento psicanalítico", Bleger (1988) introduz a noção de enquadramento. Segundo o autor, o enquadramento diz respeito a um "(...) 'não processo', constituído pelas constantes, pelos marcos em cujo interior se desenvolve o processo" (Bleger, 1988:311). E continua ainda mais esclarecedor: 
“(...) incluímos no enquadramento psicanalítico o papel do analista, o conjunto de fatores espaciais (ambiente) e temporais, e parte da técnica (na qual se inclui o estabelecimento e a manutenção de horários, honorários, interrupções planejadas, etc.)" (BLEGER, 1988:311).

Porém, seria bastante simplista resumir o enquadramento clínico em um mero contrato. O próprio autor desenvolve a sua ideia num sentido muito mais interessante: encara o enquadramento como uma instituição, na medida em que se trata de uma relação que se prolonga e organiza a partir da manutenção de um conjunto de normas ou atitudes (BLEGER, 1988:312). Sendo assim, constitui-se como depositária da parte psicótica da personalidade, ou seja, da parte indiferenciada e não resolvida dos vínculos simbióticos primitivos. Como consequência, tomar o enquadramento apenas como um conjunto de regras é limitador inclusive para o manejo terapêutico.

A aplicação do enquadre diferenciado a partir de um olhar psicanalítico acarreta numa posição importante que merece ser explicitada. Neste tipo de atuação, guiar-se pela teoria psicanalítica vai além de conceitos metapsicológicos como angústia, Complexo de Édipo, narcisismo entre outros. Como ressaltou Herrmann (2004) a psicanálise é compreendida aqui como um método único de pesquisa do fenômeno humano que se assenta sobre o pressuposto de Politzer (1928) de que toda conduta humana tem sentido por mais incompreensível que possa parecer à primeira vista. Desta forma, a prática clínica desenvolvida num enquadre diferenciado é compreendida como uma forma de se contemplar o fenômeno humano e respeitar sua condição existencial (AIELLO-VAISBERG, 2004).

Winnicott através de uma extensa experiência clínica amplia a noção de enquadramento, admitindo a possibilidade - dependendo da situação - de haver uma atuação por parte do psicanalista mais apropriada do que aquela prevista no enquadre clássico (AIELLO-VAISBERG, 2004a). Por meio de diversos relatos clínicos, Winnicott (1984) compartilhou suas experiências com enquadres não tradicionais utilizando o método psicanalítico. O próprio autor afirma: "Gosto de fazer análise e anseio por seu fim. A análise só pela análise para mim não faz sentido. 
Faço análise porque é do que o paciente necessita. Se o paciente não necessita de análise então faço alguma outra coisa." (WINNICOTT, 1990:152).

O fato de Winnicott afirmar que oferece ao paciente o que ele necessita dialoga diretamente com a noção de ilusão e desilusão. Quando o bebê nasce, a mãe identifica-se profundamente com ele, embora não regrida ao ponto de deixar de ser adulta (WINNICOTT, 1988/2006). A mãe oscila entre ser o que o bebê tem capacidade para encontrar; e ser ela mesma, enquanto aguarda ser encontrada novamente (WINNICOTT, 1971/1975:70). Do ponto de vista do bebê só o que existe é ele próprio de modo que, inicialmente, a mãe é parte dele. Esta adaptação ao bebê é tão refinada que a mãe oferece determinado cuidado no momento em que o filho necessita. Como há esta indiferenciação, o bebê tem a ilusão de que ele mesmo está suprindo suas necessidades. Com o tempo, a mãe se distancia desta identificação intensa e assim, ocorrem falhas na medida em que não oferece ao bebê o que ele precisa exatamente no momento em que necessita. Estamos falando da desilusão, que de acordo com Winnicott (1988/2006) é fundamental para o desenvolvimento sadio da criança, pois é a partir daí que ela começa a diferenciar o eu do não eu.

A formulação desta passagem está relacionada com a observação da interação entre bebês, uma espátula colocada sobre a mesa e suas mães, conhecido como Jogo da Espátula (WINNICOTT, 1941/2000). A maneira como o bebê se aproximava da espátula, a manuseava e incluía a mãe neste processo fez com que Winnicott se debruçasse sobre o hiato entre a realidade interna e externa. Pensando nos processos que se dão entre esses dois universos, Winnicott (1941/2000) desenvolve sua teoria acerca dos Objetos e Fenômenos Transicionais.

"(...) a terceira parte da vida de um ser humano, parte que não podemos ignorar, constitui uma área intermediária de experimentação [grifo do autor], para a qual contribuem tanto a realidade interna quanto a vida externa. Trata-se de uma área que não é disputada, porque nenhuma reivindicação é feita em seu nome, exceto que ela exista como lugar de repouso para o indivíduo empenhado na perpétua tarefa humana de manter as realidades internas e externas separadas, ainda que inter-relacionadas." (WINNICOTT, 1971/1975:15) 
Se observarmos um bebê (entre 4 e 8 meses de idade em média) na hora de dormir poderemos notar, muitas vezes, fenômenos - o manuseio de uma bola de lã, ponta de um cobertor, uma palavra, um maneirismo - que são imprescindíveis para o bebê amenizar a ansiedade especialmente de cunho depressivo (WINNICOTT, 1971/1975). Neste ponto, o bebê ainda não distingue claramente a realidade interna e a externa, ou seja, quando manuseia um ursinho de pelúcia, está lidando ao mesmo tempo com uma vivência subjetiva e objetiva, de criatividade e percepção (WINNICOTT, 1971/1975:19).

A partir da elaboração sobre o brincar, Winnicott (1971/1975) expõe um conceito fundamental, o qual Safra (1999) considera nuclear para o alargamento do setting psicanalítico: o Espaço Potencial. De acordo com Winnicott (1971/1975), o Espaço Potencial é o lugar simbólico existente entre o indivíduo e o objeto (ambiente), em outras palavras, entre o eu e o não eu e depende diretamente da confiança estabelecida nesta relação. É no Espaço Potencial onde é possível experimentar o viver criativo, o brincar e a análise. A criação de um Espaço Potencial entre analista e paciente é o que vai possibilitar que a experiência em toda a sua extensão aconteça (GIL, 2010). Trata-se, portanto, de um espaço completamente subjetivo e relacional, não se restringindo a um lugar físico determinado, o que permite a extensão do método de investigação psicanalítico para outros ambientes diferentes do setting clássico (SAFRA, 1999).. É esta fundamentação que nos permite uma ação terapêutica através de enquadres diferenciados pautados na teoria winnicottiana.

Com o desenvolvimento da percepção da diferença entre o mundo interno e o externo, esse objeto de valor transicional deixar de ser tão investido de energia psíquica, de modo que o seu sentido se desvanece e difunde para outras áreas deste território intermediário. Winnicott (1971/1975) afirma que o campo cultural será exatamente o destino desse sentido difuso. Como podemos observar:

"Nesse ponto, meu tema se amplia para o do brincar, da criatividade e apreciação artísticas, do sentimento religioso, do sonhar, e também do fetichismo, do mentir e do furtar, a origem e a perda do sentimento afetuoso, o vício em drogas, o talismã dos rituais obsessivos, etc." (WINNICOTT, 1971/1975:19). 
A teoria dos fenômenos e objetos transicionais vai embasar a forma como Winnicott encarou a brincadeira, inclusive no contexto analítico. Diferente do que era feito até então, ele apreende o brincar para além de um simples artifício que driblava a dificuldade de comunicação verbal das crianças em relação aos seus conflitos (WINNICOTT, 1971/1975:61). Assim, o enfoque exclusivo no conteúdo abriu espaço para um olhar sensível acerca da brincadeira como algo em si.

Com o passar do tempo, a criança poderá, na presença de alguém significativo, permitir e fruir a sobreposição de duas áreas do brincar: realizará, então, um jogo, que será testemunhado e refletido pela pessoa em questão, surgindo a oportunidade de brincar com alguém (WINNICOTT, 1971/1975; SAFRA, 1999). Aí encontramos o cerne da análise.

Para compreender melhor, é preciso estender ainda mais essa explanação e falar sucintamente do Jogo do Rabisco. Em "Consultas Terapêuticas em Psiquiatria Infantil" Winnicott (1984) traz o relato de alguns casos no qual o rabisco aparece como veículo de comunicação entre ele e seus pacientes. O Jogo do Rabisco "deve ser concebido como um facilitador dialógico que pode favorecer a manifestação subjetiva, para além dos conteúdos conscientes ou intelectualizações dissociadas da experiência." (MANNA, et al., 2012:319). Consiste no seguinte: o terapeuta faz um rabisco qualquer numa folha de papel e este deve ser transformado em um desenho pelo paciente. Depois é a vez deste último que faz o seu rabisco e o terapeuta transforma-o em um desenho e assim por diante.

A maneira como o autor propõe a técnica não coloca o terapeuta num papel de "preenchedor" de espaços vazios do paciente: os dois estão imersos igualmente numa brincadeira que possibilita, concretamente, a simbolização e a integração. Tampouco trata o desenho como um código que deve ser literalmente lido ao paciente. Sobre isso, Prochet (1993) afirma:

O que torna o jogo do rabisco original é que não é apenas a criança, mas, igualmente o terapeuta, expressam-se e comunicam-se graficamente. $O$ simbolismo mais do que nunca só pode encontrar sua significação dentro da relação estabelecida pela dupla, no espaço interpessoal. Quando o rabisco de um é completado pelo rabisco do outro, abre-se o campo dialético do espaço potencial integrando aspectos inconscientes tanto do terapeuta como do paciente. $\mathrm{O}$ jogo não tem sentido sem um dos participantes. $O$ 
terapeuta coloca seu brincar e seu inconsciente a serviço da realidade interna do paciente sem deixar de ser o tempo todo ele mesmo. (PROCHET, 1993:52)

Winnicott (1987) valorizava a liberdade absoluta em relação ao Jogo do Rabisco. Tanto que se mostrou relutante em reunir suas ideias acerca deste tema, pois temia "dar início a uma 'técnica de rabiscos' na condição de rival de outras técnicas projetivas" (WINNICOTT, 1987:116), não querendo cair em algo estereotipado. Winnicott considerava fundamental que o Jogo do Rabisco pudesse ser adaptado à realidade de cada paciente e se adequasse às especificidades de cada relação terapêutica (WINNICOTT, 1987), acrescentando que, agradava-Ihe mais que cada profissional desenvolvesse a sua própria técnica.

Os rabiscos de Winnicott nunca eram uma forma fechada, conhecida. O paciente se sentia provocado pelo desenho, fosse por sua instabilidade e/ou pelo desejo de dar forma a ele. O Jogo do Rabisco contém o caráter que Winnicott denominou de formlessness (WINNICOTT, 1945/2000), que diz respeito a algo (material ou imaterial) que permite um "manuseio" e significação de acordo com a necessidade do paciente.

O termo "enquadre diferenciado" não se encontra expressamente na obra de Winnicott, mas foi formulado a partir de suas construções teóricas. De acordo com Aiello-Vaisberg e Machado (2003) os enquadres diferenciados objetivam a promoção de experiências emocionais mutativas, ou seja, de transformações que se dão num plano existencial. Assim, contrapõem-se àquelas práticas psicanalíticas que se propõem a mudanças em registro mental, discursivo ou simbólico a partir de pressupostos que valorizam o saber sobre si mesmo. As autoras salientam que este último enfoque contribui sobre a remissão sintomática, mas embasa-se no pensamento e não no sentir, essencial à compreensão das vivências agônicas. Enquadres clínicos não tradicionais valem-se de intervenções não interpretativas. Portanto, o que está no cerne não é a decifração, pelo terapeuta, de sentidos ocultos no discurso ou em qualquer outra forma de expressão do paciente (AIELLOVAISBERG; MACHADO, 2003). Isso porque, segundo Winnicott (1971/1975:81): "Sabemos que neste tipo de trabalho [terapêutico], mesmo a explicação correta é 
ineficaz. A pessoa a quem estamos tentando ajudar necessita de uma nova experiência, num ambiente especializado".

Os enquadres diferenciados almejam oferecer uma sustentação emocional capaz de garantir a expressão do paciente como ser humano criador (AIELLOVAISBERG; MACHADO, 2003). A partir de um ponto de vista winnicottiano, a psicoterapia em si e a artepsicoterapia (AIELLO-VAISBERG; AMBROSIO, 2007) auxiliam o paciente a superar dissociações entre falso e verdadeiro self, visando à maior autenticidade pessoal e ao desbloqueio causado por uma falha ambiental no início da vida ou por invasões ambientais ocorridas ao longo do desenvolvimento.

Ao utilizar materialidades mediadoras autoexpressivas e por não ser feito o uso de interpretações do inconsciente, não se coloca o paciente em situações constrangedoras quando trabalhamos em grupo. Pesquisas com enquadres grupais buscam o desenvolvimento qualitativo de práticas clínicas a serem implementadas em equipamentos de saúde mental pública (AIELLO-VAISBERG; MACHADO, 2003). Ao desenvolver a atividade relacionada ao material à disposição em um ambiente sustentador da continuidade do ser, cada participante tem a oportunidade de ter uma experiência de fazer criativo.

O ambiente onde se desenvolve a oficina terapêutica se fundamenta no conceito de holding de Winnicott (1990, 1991,1988/2006). Tal termo, para o autor, resume "tudo aquilo que uma mãe é e faz." (WINNICOTT, 1988/2006:4) e consequentemente o que "cria as condições necessárias para que se manifeste o sentimento de unidade (...)" (WINNICOTT, 1990:138) e continuidade do self. No contexto das oficinas, busca-se oferecer um espaço de confiança, para que, nele, cada participante possa arriscar um movimento pessoal, uma gestualidade espontânea que está profundamente ligada à possibilidade de uma apropriação autêntica de si e um posicionamento real e presente no mundo (CAMPS, 2009). terapeuta assume um papel reassegurador para que este processo se desenvolva.

Neste contexto, a materialidade mediadora escolhida atua como facilitadora do brincar, de modo a gerar condições para a expressão do gesto espontâneo e de uma vivência criativa no mundo (GIL, 2010). Desta forma, é importante que estes 
materiais sejam portadores desta característica chamada formlessness (WINNICOTT, 1945/2000) e assemelhem-se, portanto, ao "rabisco" de Winnicott.

Nesta dissertação, o desenho e a pintura foram encarados como detentores deste caráter formlessness. Um desenho ou uma pintura nunca é uma representação objetiva. Ao contrário: ali são expressos conteúdos próprios de seu autor. É, portanto, encarado como uma produção projetiva e nesse sentido, como expressou Tardivo (2007) é produto de uma síntese pessoal. Cada estímulo projetivo põe em questão o potencial de recriação que se baseia na capacidade reparadora (GRASSANO, 1996). Tardivo (2007) complementa:

Cada desenho pode ser concebido como resultado e evidência das tentativas bem sucedidas ou fracassadas, de forma total ou parcial, da capacidade de integração e reparação. Os impulsos reparadores, entre os quais a sublimação e a criatividade tendem a integrar, completar, dar vida emocional ao objeto incompleto (o estímulo projetivo) que é oferecido. (TARDIVO, 2007: 54).

A folha em branco preenchida pelo sujeito transforma-se num estímulo de apercepção temática por envolver dois aspectos ressaltados por Trinca (1972): de um lado o próprio desenho livre como um conjunto de formas gráficas de expressão e de outro, o processo que envolve a verbalização de associações relacionadas à percepção de certos estímulos. Assim, os desenhos livres constituem-se como um ótimo meio para observar o desenvolvimento mental, a experiência de mundo e a personalidade de uma criança (ANZIEU, 1979).

Tardivo (1986) sugere que a avaliação do desenho livre também seja livre, podendo adotar um referencial psicanalítico, como a análise de um sonho, uma sessão terapêutica ou uma hora lúdica. Tratar-se-ia de uma "livre inspeção do material", que busca uma interpretação do conjunto: desenho e associações possibilitando a compreensão do drama que ali é encerrado (TARDIVO, 2007).

Quando pensamos numa atuação junto a crianças e adolescentes abrigados, os enquadres diferenciados pautados na teoria de Winnicott surgem como uma opção forte no cuidado terapêutico. Para haver o afastamento das figuras parentais, 
falhas no cuidado muito graves ocorreram. Consequentemente, é comum observar nesta população certa reserva em relação a figuras que desempenham funções cuidadoras exatamente pelas vivências traumáticas anteriores e pelos conflitos com os educadores do abrigo. Assim, muitas crianças e adolescentes apresentam resistência em aceitar um trabalho terapêutico individual e tradicional. Aspectos como o estabelecimento de um vínculo de confiança e interpretações psicanalíticas a partir de vivências tão doloridas são fatores que dificultam a aderência ao tratamento. Por estes motivos, a opção por enquadres não tradicionais que respeitem a condição existencial e ofertem um ambiente propício para a ocorrência de experiências mutativas se configuram como uma alternativa efetiva de psicoterapia.

\section{A pesquisa com oficinas terapêuticas no Laboratório de Saúde Mental e Psicologia Clínica Social do Departamento de Psicologia Clínica do IPUSP}

A partir da década de 1990, surge no Instituto de Psicologia da Universidade de São Paulo (IPUSP) o estilo clínico 'Ser e Fazer' criado pela Prof. Tânia Maria José Aiello Vaisberg (AMBROSIO, 2013). Orientado por uma proposição psicanalítica, o estilo clínico 'Ser e Fazer', se debruça sobre o estudo e aplicação de inúmeras possibilidades interventivas dos enquadres diferenciados voltados a indivíduos ou grupos que vivenciavam sofrimento emocional.

Neste contexto, os mais diversos tipos de materiais são utilizados para favorecer a expressão genuína dos participantes.

"Toda e qualquer forma de comunicação humana pode ser usada como procedimento mediador: desenhos, estórias, observação de quadros previamente compostos, dramatizações, invenção de histórias em quadrinhos, pintura, escultura, colagens, além dos mais variados jogos". (AIELLO-VAISBERG; MACHADO, 2003:9) 
Ambrosio (2013) resume os pressupostos do estilo clínico 'Ser e Fazer' nos seguintes pontos:

1) O uso de materialidade expressivas com potencial criativo;

2) Intervenções fundamentadas no holding (WINNICOTT, 1991);

3) Preferência pelo enquadre grupal.

Ancorado em tais premissas, em 1997, no IPUSP é criada a "Ser e Fazer": Oficinas Psicoterapêuticas de Criação ${ }^{8}$. Por estar inserida no contexto da universidade, a 'Ser e Fazer' já abrigou e abriga diversas pesquisas, projetos de mestrado, doutorado e pós-doutorado. Entre eles observamos o amplo uso de materialidades mediadoras com finalidades terapêuticas: tapeçaria e bordados (MANNA; AIELLO-VAISBERG, 2006), velas ornamentais (MENCARELLI, BASTIDAS; AIELLO-VAISBERG, 2003; MENCARELLI, 2003), teatro espontâneo (CAMPS, 2003, 2009) arranjos florais (VITALI; AIELLO-VAISBERG, 2003, VITALI, 2004), confecção de papel (AMBROSIO, 2005; AIELLO-VAISBERG; AMBRÓSIO, 2007), fotos, histórias e lembranças (CIA, AMBROSIO; AIELLO-VAISBERG, 2007), contos de fadas (LABATE et al., 2008).

Num levantamento bibliográfico de produções mais recentes, encontramos relatos de trabalhos de pesquisadores da Ser e Fazer que utilizaram outros enquadres diferenciados associados às materialidades mediadoras. Diversos deles se valeram de técnicas gráficas, mais precisamente o procedimento de Desenho Estória com Tema (AIELLO-VAISBERG, 1997, 1999) entendido não como teste projetivo, e sim como um procedimento apresentativo expressivo (MANNA et al., 2012).

Manna, et al. (2012) ao discorrerem sobre o uso do desenho estória com tema no contexto das pesquisas Ser e Fazer, explica que é solicitado aos participantes do grupo que façam um desenho cujo tema expresse um interesse convergente. No verso da folha, é então solicitado que cada um escreva uma estória sobre o desenho elaborado. Após o término, os desenhos são colocados onde todos possam ver e se estabelece uma conversa livre (MANNA et al., 2012:320).

\footnotetext{
${ }^{8}$ Projeto hospedado no Laboratório de Saúde Mental e Psicologia Clínica Social do Departamento de Psicologia Clínica do IPUSP sob a coordenação da Profa Livre Docente Leila Salomão de La Plata Cury Tardivo.
} 
Foram encontrados diversos estudos sobre imaginário coletivo nos quais observou-se o uso do Desenho Estória com Tema. Gallo-Beluzzo, Corbett e AielloVaisberg (2010) investigaram o imaginário coletivo de alunos do sétimo semestre de Psicologia sobre o primeiro atendimento. Ambrosio, Fialho e Aiello-Vaisberg (2010) estudaram o imaginário coletivo de estudantes de educação física sobre uma vida saudável. Corbett, Gallo-Beluzzo e Aiello-Vaisberg (2010) abordaram o imaginário coletivo de estudantes de Psicologia sobre dificuldades sexuais femininas. Barcelos, Cia e Aiello-Vaisberg (2011) aplicaram o desenho estória com tema em um grupo de professores que deveriam representar o adolescente contemporâneo. Simões, Riemenschneider e Aiello-Vaisberg (2012) inspecionaram o imaginário de trabalhadores de saúde mental sobre pacientes psiquiátricos. Neste trabalho, além dos desenhos também foi usada a apresentação de slides como facilitador da conversa.

$O$ uso de enquadres diferenciados em psicoterapia também é alvo de pesquisas dentro do Projeto APOIAR', criado em 2002 (TARDIVO; GIL, 2008), no Instituto de Psicologia da Universidade de São Paulo.

Leoncio (2003) apresenta em seu mestrado um estudo realizado com 13 crianças e adolescentes abrigados no qual se valeu do Procedimento de Desenho Estória. A partir da produção gráfica e de entrevistas, a autora salienta a problemática das famílias multicarenciadas e a intensificação dos sentimentos de desproteção e desamparo das crianças após a ida para a instituição.

Barros, Gil e Tardivo (2008) relatam um caso clínico de um rapaz de 18 anos. Atendido individualmente, o rapaz tinha uma queixa inicial de falta de memória e na sequência das sessões, ele relata sentir um grande cansaço que o impedia de realizar suas tarefas cotidianas, restando energia apenas para os jogos de computador. A partir de determinado momento, a terapeuta começou a levar lápis e papel para as sessões. Iniciou-se então uma espécie de Jogo do Rabisco, através do qual o paciente pôde se ver capaz, posição esta pouco conhecida por ele.

\footnotetext{
9 Projeto hospedado no Laboratório de Saúde Mental e Psicologia Clínica Social do Departamento de Psicologia Clínica do IPUSP sob a coordenação da Profa Livre Docente Leila Salomão de la Plata Cury Tardivo.
} 
Silva et al. (2010) realizaram oficinas terapêuticas em um hospital psiquiátrico feminino como parte integrante do programa de estágios obrigatórios em Psicopatologia do Instituto de Psicologia da Universidade de São Paulo. Realizaram diversas intervenções como alongamentos, danças circulares, leituras e canto com um grupo de pacientes que variava a cada semana. $O$ fato de se tratar de uma população com transtornos psiquiátricos exigiu muita flexibilidade e sensibilidade por parte dos alunos que observaram como um psicólogo pode atuar auxiliando na busca de sentido. Ressaltam a importância do caráter não interpretativo do enquadre das oficinas terapêuticas.

Gil (2010) apresenta em seu doutorado a experiência da Oficina de Cartas, Fotografias e Lembranças desenvolvidas com idosos. Apesar da proposta inicial, ao longo do trabalho, foram agregados muitos outros objetos caros aos participantes além de fotografias e cartas (objetos de decoração, panos de prato, bonecos, entre outros.). As experiências dos encontros somadas aos dados obtidos no WHOQOLBREF (Inventário de Qualidade de Vida Forma breve), o BDI (Inventário Beck de Depressão) e o Teste de Apercepção Temática para Idosos (SAT), forneceu à pesquisadora dados que demonstraram a eficácia terapêutica do enquadre diferenciado utilizado. $O$ enquadre possibilitou maior integração e a possibilidade da recordação saudável, que refletiu na diminuição dos sintomas depressivos apreendidos no início dos encontros.

Schvartzaid, Schwarz e Tardivo (2011) utilizaram o Desenho da Família como veículo expressivo em atendimentos em psicoterapia breve de uma paciente com quadros depressivos. Foram ao todo 12 encontros semanais nos quais o desenho foi empregado e segundo as autoras favoreceu insights e a consciência da necessidade de um olhar mais voltado para as suas questões e crescimento pessoal.

Luz et al. (2011) utilizaram o Procedimento de Desenho Estória com Tema com um grupo de 4 crianças abrigadas entre 8 e 10 anos. $O$ objetivo era investigar a percepção que possuíam do abrigo. Através das suas produções gráficas, as crianças puderam expressar o caráter ambivalente da instituição que transita entre o papel de acolhimento e prisão. 
O Desenho Estória com Tema também foi usado como um veículo apresentativo expressivo no trabalho apresentado por Passarini, Colacique e Tardivo (2012). Nesta ocasião, o procedimento foi utilizado para mediar a conversa com um grupo de adolescentes abrigadas com seus filhos. $O$ tema versava exatamente sobre esta condição e a partir das produções foi possível compreender o desenvolvimento afetivo de cada participante e a raiva da instituição associada à esperança de obtenção de ajuda para suas necessidades. 


\section{JUSTIFICATIVAS E OBJETIVOS}

Tomando-se o aporte teórico apresentado anteriormente, vimos que o abrigo como instituição de acolhimento de crianças e adolescentes é uma estrutura relativamente recente no nosso país. Estruturados a partir da promulgação do Estatuto da Criança e do Adolescente em 1990, os abrigos têm como objetivo último prover condições adequadas para que crianças e adolescentes possam continuar seu desenvolvimento da melhor forma possível enquanto estão afastados de suas famílias.

De acordo com a estimativa da pesquisa em andamento realizada pelo Ministério do Desenvolvimento Social e Combate à Fome (MDS, 2010), existiriam por volta de 54000 crianças e adolescentes abrigados. Ou seja, um número expressivo de crianças e adolescentes no nosso país passa pela experiência da institucionalização.

Diante deste contexto, torna-se importante o desenvolvimento de pesquisas que procurem conhecer melhor quem são estes sujeitos e como lidam com a condição de acolhimento nos moldes que temos atualmente. Estudos neste tema contribuem para o aperfeiçoamento de políticas públicas desenvolvidas para esta finalidade.

Assim, a presente pesquisa possui os seguintes objetivos:

- Realizar o estudo clínico de crianças e adolescentes abrigados a fim de conhecer e compreender a maneira como vivem a experiência do acolhimento institucional e o afastamento da família, que, como vimos, imprimem marcas substanciais nos indivíduos.

- Discutir o alcance da Oficina Expressiva de Desenho e Pintura como modelo interventivo grupal na comunicação e elaboração de aspectos mal integrados tanto das crianças e adolescentes como de seu cuidador. 
- Apresentar e buscar a compreensão das vivências emocionais sustentadas pelo enquadre diferenciado da Oficina no que se refere, principalmente, à experiência do acolhimento institucional. 


\section{MÉTODOLOGIA}

Considerando que a pesquisa tem dois focos: o estudo e a compreensão dos participantes quanto o acolhimento institucional e a apresentação de uma oficina terapêutica como modalidade interventiva, considerou-se necessário iniciar este capítulo por uma digressão sobre o psicodiagnóstico compreensivo e o método clínico em pesquisas, dois pilares que estruturaram este trabalho.

Em seguida, serão apresentados os dados concernentes: a apresentação dos participantes, a descrição das etapas do processo e os instrumentos utilizados.

\section{A. Breves considerações sobre o psicodiagnóstico compreensivo e o método clínico}

A concepção de diagnóstico compreensivo se fundamenta na apreensão ampla do sujeito ao integrar múltiplos referenciais (biológico, social, intelectual etc.), evitando assim a unilateralidade (TRINCA, 1984:11). O autor destaca a necessidade de se encontrar um sentido para o conjunto de informações a cerca do indivíduo, destacando o mais relevante e significativo da sua personalidade. $O$ autor ressalta, que, dependendo do que requer a situação, é possível enfatizar um desses pontos, sem nunca perder de vista a unidade do sujeito. Contudo, por mais completo que seja, é importante que tenhamos claro o fato do psicodiagnóstico dizer respeito a um momento de vida do sujeito, constituindo-se fundamentalmente por uma hipótese (TRINCA, 1984). Para a realização desta síntese, Trinca (1984) prevê a utilização de diversas técnicas de exame psicológico fundamentadas na associação livre que promovem a emergência de aspectos inconscientes, imprescindíveis para uma compreensão dinâmica. 
Tardivo (2007a) e Aiello-Vaisberg (1999) chamam a atenção para a impossibilidade de se dissociar o caráter de investigação e intervenção do diagnóstico psicológico. A partir do momento em que o paciente começa a trabalhar junto com o terapeuta, não importando se estão ainda num processo diagnóstico, as relações de transferência e contratransferência, e portanto, terapêuticas, já estão operando. Portanto, o caráter interventivo do psicodiagnóstico se baseia numa postura criativa que integra compreensão e intervenção que ocorre no encontro do paciente e terapeuta (TARDIVO, 2007a).

Autores como Ocampo, Arzeno e Piccolo (1981) e Grassano (1996) enfatizam a importância da finalização do processo diagnóstico através de entrevistas devolutivas como possibilidade de integração.

De forma complementar ao psicodiagnóstico compreensivo, o método clínico de debruça sobre a discussão e compreensão das relações de sentido e significados de fenômenos humanos (TURATO, 2004). O autor ainda ressalta que tal viés metodológico fundamenta-se nas trocas afetivas, na escuta da fala do sujeito, e também dos aspectos globais da linguagem corporal e do comportamento durante 0 contato terapêutico. Portanto, o método clínico enfatiza a maneira como se dá 0 processo (LUDKE; ANDRÉ, 2006).

Sob uma orientação psicanalítica, o método clínico oferece um cuidado às angústias e aos conflitos contextualizando-os social, política e culturalmente (GIL, 2010). Aiello-Vaisberg (2004) considera que o fundamento do método psicanalítico é a certeza de que não existem limites para a compreensibilidade do fenômeno humano. Caracteriza-se pelo conjunto entre a livre associação do paciente e a atenção flutuante do terapeuta (AIELLO-VAISBERG, 2006). Assim, não se privilegia nenhum elemento a priori no discurso do paciente, o que implica no fato do terapeuta deixar seu próprio inconsciente livre e suspenso de motivações pessoais. Essa construção é orquestrada de tal forma que visa à abertura máxima das possibilidades de comunicação e compreensão, abarcando, inclusive, manifestações não verbais (AIELLO-VAISBERG, 2006). A produção do conhecimento se dá numa dimensão sujeito-sujeito, mas isso não significa que ocorra um trato exclusivamente subjetivo e muito menos que não exista um rigor metodológico a ser empregado (AIELLO-VAISBERG, 2004). 
Aiello-Vaisberg (1999) afirma que o uso de instrumentos projetivos pode ser definido como modalidades práticas por meio das quais o método psicanalítico pode ser concretizado. No entanto, é importante deixar claro que tais instrumentos não serão utilizados com intuito interpretativo.

No contexto desta dissertação, nos interessa explicitar a conclusão apresentada por Serafini, Ávila e Bandeira (2005). Os autores apontam para uma necessidade urgente no estudo de instrumentos de investigação psicológica junto à população de crianças e adolescentes abrigados. Como justificativa, afirmam que crianças abrigadas apresentam respostas muito particulares e características das vivências pelas quais passaram e o fato de apresentarem respostas que diferem da amostra normativa não indica necessariamente fatores patologizantes, mas específicos desta população.

\section{B. Participantes}

A casa abrigo onde o trabalho foi realizado, como já mencionado, situa-se em um município da Grande São Paulo. No período em que a pesquisa se iniciou, tinha apenas 11 adolescentes e crianças abrigadas. No horário proposto para a oficina, havia na casa cinco crianças e adolescentes que participariam da atividade: três meninas e dois meninos e ainda o educador indicado pela coordenação do abrigo pela boa qualidade do seu trabalho e pelo bom relacionamento com os meninos (quesitos suscitados pela própria instituição e não pela pesquisadora). Porém, uma semana antes do início das atividades, os dois meninos se evadiram do abrigo. Sendo assim, participaram apenas três meninas - Gabriela ${ }^{10}$ (10 anos), Maiara (13 anos) e Josi (16 anos) - e Roberto, educador da casa. Durante as entrevistas iniciais, cada membro do grupo obteve esclarecimentos sobre o trabalho e foi perguntado se gostaria de participar, deixando-se claro a questão no anonimato e da possibilidade de desistência a qualquer momento. Uma vez consentida a

\footnotetext{
${ }^{10}$ Todos os nomes contidos nesta dissertação são fictícios para preservar o anonimato dos participantes.
} 
participação, foi assinado um Termo de Consentimento Livre e Esclarecido ${ }^{11}$ pela coordenadora do abrigo (e no caso de Roberto, também por ele mesmo).

\section{Procedimento}

O presente trabalho se desenvolveu ao longo de sessões semanais que englobaram entrevistas individuais com Roberto e cada uma das meninas participantes; os 12 encontros fundamentados no enquadre diferenciado da Oficina Expressiva de Desenho e Pintura; e entrevistas finais individuais com os participantes do grupo e a coordenadora da instituição.

Nestas entrevistas iniciais individuais foram utilizados alguns instrumentos com o intuito de conhecer melhor a dinâmica de cada participante bem como investigar aspectos específicos como a vivência de violência doméstica e características de um quadro depressivo. Foram eles: O Desenho da Figura Humana (DFH) (MACHOVER, 1949), o teste do Desenho da Pessoa na Chuva (QUEROL; PAZ, 1997), o Teste das Fábulas de Düss (DÜSS, 1986), o Inventário de Frases no Diagnóstico de Violência Doméstica (IFVD) (PINTO JÚNIOR; TARDIVO, 2010) e o Children Depression Inventory (CDI) (KOVACS, 1983). Todos os instrumentos utilizados serão explicitados nos tópicos a seguir. Vale salientar que as avaliações do DFH, do desenho da Pessoa na Chuva e o teste das Fábulas se deram através da livre inspeção do material (TARDIVO, 2007). Ou seja, buscou-se uma interpretação do conjunto da produção de cada participante associando-se aos dados obtidos nas entrevistas e nos inventários.

O uso de instrumentos de exame psicológico se restringiu apenas às meninas participantes, uma vez que se compreendeu a presença de Roberto de acordo com a solicitação da coordenadora do abrigo que buscava uma aproximação entre a equipe de educadores e os abrigados. É importante ressaltar que grande parte dos adolescentes abrigados na casa no momento em que esta pesquisa se iniciou havia sido transferida de outra unidade que fechara há mais ou menos um ano. Esta

\footnotetext{
${ }^{11}$ Cópia do Termo de Consentimento Livre e Esclarecido pode ser encontrado no Anexo A ao final do trabalho.
} 
transferência foi marcada por conflitos entre os adolescentes e a equipe do novo abrigo, daí a solicitação da coordenadora.

Foi realizada uma primeira entrevista com Roberto sobre o seu trabalho no abrigo. Buscou-se obter informações sobre como ele via o trabalho de educador de abrigo, como se relacionava com as crianças e adolescentes, como lidava com as dificuldades inerentes ao trabalho etc.

Posteriormente Roberto contou um pouco sobre cada uma das meninas participantes do grupo. O fato do educador que participaria das oficinas ser o mesmo a fornecer dados da história de vida das meninas foi uma coincidência e não exigência da pesquisa. Ele, dentre os educadores, foi indicado pela coordenação do abrigo por ser aquele que está há mais tempo em contato com todas elas, e portanto, o que reúne mais informações. O objetivo desta segunda entrevista foi levantar dados sobre cada criança ou adolescente (nome, idade, razão do acolhimento, adaptação à condição de abrigado, existência de queixas comportamentais ou dificuldades emocionais, etc.).

Concluída esta etapa, a pesquisadora entrevistou cada uma das meninas. Primeiramente se apresentou, explicou o projeto e na medida em que teve a aquiescência destas, iniciou uma entrevista mais informal para saber sobre hábitos cotidianos, hobbies, escola, só então adentrou na questão do abrigo em si: há quanto tempo estavam abrigadas, o motivo, contato com a família, adaptação à instituição, investigação de possíveis conflitos. Na sequência foram aplicados os instrumentos de exame psicológico de acordo com as instruções de seus autores como vemos a seguir:

- Para as técnicas gráficas (DFH e Desenho da Pessoa na Chuva) apresentou-se uma folha de papel branca, tamanho A4 para cada desenho. A participante tinha a sua disposição lápis grafite $\mathrm{n}^{\circ} \quad 2$, borracha e apontador. Então se pediu que desenhassem uma pessoa no caso do DFH (MACHOVER, 1949), e no teste do Desenho da Pessoa na Chuva, foi requisitado que desenhasse uma pessoa na chuva (QUEROL; PAZ, 1997). Para estas atividades não havia tempo prédeterminado, cabendo ao terapeuta observar a maneira como cada indivíduo cumpriria as tarefas solicitadas. 
- O Teste das Fábulas de Düss (DÜSS, 1986) consiste em pequenas histórias que sempre terminam com uma pergunta acerca da continuidade ou sentido de alguma atitude/sentimento do herói da fábula. Portanto as fábulas foram lidas pela pesquisadora e foi solicitado que cada participante respondesse a estas questões, resultando em produções pessoais ligadas à dinâmica psíquica de cada uma das meninas participantes.

- O IFVD (PINTO JÚNIOR; TARDIVO, 2010), consiste em 57 perguntas lidas pela aplicadora. Ao término da leitura de cada questão, foi solicitado que respondessem "SIM", caso se sentisse que o conteúdo da pergunta acontecia consigo na maioria das vezes; ou "NÃO" se não acontecesse consigo na maioria das vezes. Ao final obteve-se uma pontuação, que se fosse maior do que 22 pontos. indicava fortes indícios de violência doméstica bem como os transtornos associados a esta experiência: transtornos emocionais, físicos, comportamentais, cognitivos e sociais.

- O CDI (KOVACS, 1983) é formado por um questionário de 27 itens. Cada um é composto por três afirmativas, lidas às participantes que deviam indicar qual correspondia melhor ao que acontecia consigo. Cada alternativa correspondia a um valor de pontuação: 0,1 ou 2. No Brasil, o ponto de corte situa-se em 17 pontos (BARBOSA; LUCENA, 1995).

Os aspectos observados no processo diagnóstico foram trabalhados no decorrer das atividades da Oficina, visando ao fortalecimento do self. Os doze encontros transcorreram sempre no mesmo dia da semana e mesmo horário. O espaço destinado para as atividades era o refeitório da instituição que se situava num espaço de trânsito constante, ligação entre a ala masculina/administração e a cozinha/ala feminina. O ambiente era arejado e ventilado, dotado de uma mesa grande - adequada à atividade.

Ao término destes encontros, na entrevista individual final, houve a reaplicação do Teste do Desenho da Pessoa na Chuva e do CDI. A reaplicação destes instrumentos objetivou observar possíveis mudanças nas meninas participantes de modo a ampliar a compreensão das mesmas e o alcance do enquadre diferenciado escolhido como promotor de experiências mutativas. Além disto, buscou-se integrar o processo e ouvir como cada participante vivenciou a experiência da Oficina. 


\section{Entrevistas}

Segundo Bleger (1964:9) a entrevista é um instrumento fundamental do método clínico e configura-se como uma técnica de investigação científica em psicologia. $\mathrm{O}$ autor salienta que pode ser de três tipos:

1) Aberta: o entrevistador tem ampla liberdade para fazer as perguntas ou intervenções e deve ser flexível o suficiente para que o entrevistado configure o campo da entrevista segundo sua estrutura psicológica particular.

2) Fechada: consiste em perguntas já previstas e que são feitas respeitando a ordem, sendo consideradas pelo autor como um "questionário" (p.10);

3) Semi Aberta: formada por perguntas já estabelecidas, assim como se dá na fechada, porém o entrevistador preserva certa flexibilidade para o entrevistado transitar pelas questões, que não devem ser respondidas necessariamente em ordem.

Tendo em vista os objetivos deste trabalho e o enfoque metodológico escolhido, optou-se pela realização de uma entrevista semiaberta, uma vez que o estabelecimento de algumas perguntas padrão no levantamento de dados sobre cada participante uniformizou as informações obtidas. Por outro lado, valorizou-se a fluidez do contato, possibilitando a emergência de outras questões que poderiam colaborar para os objetivos das entrevistas que foram exatamente obter uma síntese tanto do presente como da história de cada participante (BLEGER, 1964).

Em consonância com as ideias de Bleger (1964:15), entendemos que a entrevista não substitui ou exclui outros procedimentos de exame, da mesma forma como estes últimos não podem prescindir dela. Sendo assim, a seguir encontrar-seão os instrumentos utilizados nas meninas participantes, sendo estes compreendidos como veículos complementares aos dados obtidos na entrevista. 


\section{Desenho da Figura Humana - DFH}

O Desenho da Figura Humana é classificado como técnica projetiva gráfica, sendo assim, caracteriza-se por apresentar instruções de aplicação mais amplas e estímulos menos estruturados, que oferecem ao examinando maior liberdade de associação, infinitas possibilidades de respostas, através das quais o indivíduo manifesta sua subjetividade e as características não observáveis da sua personalidade (SENDÍN, 2000).

Para Hammer (1981) os desenhos projetivos expressam aspectos muito pessoais, pois considera que, todo ser humano tende a ver o mundo segundo a própria imagem. Em outras palavras, o que está em jogo é a projeção de aspectos inconscientes, que não são reconhecidos pelo indivíduo como tal e, consequentemente, os atribui ao mundo externo. No que diz respeito ao DFH, quando um sujeito desenha um corpo humano, refere-se necessariamente às imagens internalizadas e inconscientes que tem de si próprio e dos outros (MACHOVER, 1949).

Técnicas projetivas gráficas possuem as vantagens de serem acessíveis a pessoas de baixo nível de escolaridade e/ou com dificuldades para expressar-se oralmente; são muito úteis com crianças pequenas que ainda não falam com clareza, mas que possuem um excelente grau de simbolização em atividades gráficas e lúdicas; são simples e econômicos de realizar. Além disso não apresenta nenhuma restrição de aplicação no que se refere à faixa etária. (TARDIVO, 1986).

Quando uma técnica projetiva é apresentada, o indivíduo se vê diante de um campo de estímulos pouco estruturados, que tendem a organizar a partir da sua própria percepção de mundo externo e interno. Diz Grassano (1996): "As pranchas ou instruções atuam, dentro da situação projetiva, como objetos mediadores das relações vinculares das pessoas, que mobilizam e reeditam variados aspectos da vida emocional. Neste sentido toda produção projetiva é produto de uma síntese pessoal" (p. 28).

Por essa leitura, o mais importante na avaliação dos desenhos é o aspecto qualitativo total, ou Gestalt. Através do desenho é possível comunicar tanto aspectos afetivos quanto intelectuais. Cabe ao examinador compreender os aspectos formais (como é feita a produção) e de conteúdo (O que é produzido) (TARDIVO, 1986). 
Nesta análise mais ampla, é possível apreender informações sobre a dinâmica emocional do indivíduo, independente da sua aptidão artística.

Inicialmente, o Desenho da Figura Humana fora aplicado como escala de avaliação de inteligência infantil (GOODENOUGH, 1926/1951). Porém, a partir da década de 1940, surgiu um novo olhar sobre ele e começaram a se realizar estudos sobre seu caráter projetivo (HARRIS, 1963). A primeira estudiosa a analisar desenhos da figura humana com o intuito de medir o self projetado foi Karen Machover (1949). Acreditava que a figura humana desenhada pelo indivíduo instruído a "desenhar uma pessoa", se relacionasse intimamente com os impulsos, ansiedades conflitos e compensações características desse indivíduo.

O Desenho da Figura Humana para investigação da personalidade, de Karen Machover (1949), foi difundido no Brasil em meados da década de 60, graças ao trabalho pioneiro de Lourenção van Kolck $(1981,1984)$, que introduziu este instrumento no Brasil em um estudo com adolescentes. Essa autora (1984) propõe uma análise da Figura Humana, a qual pode ser quantificada, e permite a comparação entre diferentes grupos de crianças, dando importantes indícios de sinais de ansiedade, depressão e autoestima, a partir da imagem corporal projetada, considerando ainda a importância da idade na evolução das pautas desenhadas.

As figuras humanas são os desenhos espontâneos realizados com maior frequência por crianças, antes mesmo da sua alfabetização e, por isso, as técnicas com figuras humanas são muito utilizadas com a população infantil (KOPPITZ, 1968/1973, TARDIVO, 1986).

No que se refere à representação do corpo, o DFH apresenta importante ressonância quando é aplicado em crianças e adolescentes, devido a todas as implicações relativas ao desenvolvimento corporal (MACHOVER, 1949) e à noção de como se habita e se apropria do mundo (representado pela folha de papel). desenho da pessoa também possibilita o conhecimento de habilidades sociais gerais e específicas do indivíduo, ou seja, as tendências e características predominantes em sua personalidade que podem facilitar ou dificultar a interação social e o estabelecimento de relacionamento com o outro. 
Como avaliação de personalidade, o DFH ainda não é aprovado pelo Conselho Federal de Psicologia, tendo seu uso estimulado para pesquisas ${ }^{12}$.

\section{Desenho da Pessoa na Chuva}

A origem do teste da Pessoa na Chuva é imprecisa. De acordo com Querol e Paz (1997:15), derivaria de uma técnica elaborada por M. Fay em 1924 que solicitaria o desenho de uma mulher que passeia na chuva. Hammer (1981) considera o Teste da Pessoa na Chuva como uma variação do Desenho da Figura Humana. Para ele o primeiro é um instrumento capaz de expressar as "tendências reativas" do indivíduo em situações de tensão ambiental, enquanto que o último representa o indivíduo em situações livres de tensão. Nesse sentido, o teste da Pessoa na Chuva seria um retrato do indivíduo sob condições desfavoráveis, um instrumento capaz de "conseguir uma visão de imagem corporal em condições de tensão ambiental desagradável, representadas, no caso, pela chuva" (HAMMER, 1981:299).

Segundo Vagostello (2007) o Desenho da Pessoa na Chuva consiste em uma técnica simples, que pode ser administrada individual ou coletivamente em crianças, adolescentes e adultos de ambos os sexos. O material necessário para a aplicação também não é complexo e resume-se a lápis grafite, borracha e folha de papel sem pauta que deve ser entregue ao sujeito na posição vertical mediante a seguinte instrução: "Desenhe uma pessoa na chuva." (VAGOSTELLO, 2007).

A interpretação do Teste da Pessoa na Chuva (QUEROL; PAZ, 1997), baseia-se nos mesmos princípios de interpretação da Figura Humana de Karen Machover (1949): elementos expressivos (dimensão, localização, traços, pressão, tempo e sequência de execução, movimento, sombreado) e conteúdo (posição da figura humana no papel, posturas, rasuras, linhas, detalhes acessórios e suas respectivas localizações, vestimenta, guarda-chuva ou substitutos, partes do corpo humano e identidade sexual). A chuva e o guarda-chuva são os elementos adicionais em relação ao teste de Machover. A chuva simbolizaria uma situação de tensão ou de

\footnotetext{
${ }^{12}$ Conselho Federal de Psicologia. (2003, 24 de março). Resolução no 002/ 2003-Define e regulamenta o uso, a elaboração e a comercialização de testes psicológicos e revoga a Resolução CFP $n^{\circ}$ 025/2001. Brasília, DF. Recuperado em 10 de mar.
} 
hostilidade do meio, contra a qual o sujeito precisa se proteger e o guarda-chuva, os recursos defensivos do mesmo. Na interpretação do teste, quanto mais abundante a chuva, maior é a intensidade da pressão sentida pelo sujeito. Por outro lado, a ausência de chuva pode indicar oposicionismo ou até a negação dos conflitos (VAGOSTELLO, 2007) ${ }^{13}$.

O guarda chuva representa a capacidade do uso de defesas para 0 enfrentamento das situações estressantes. No manual de aplicação (QUEROL; PAZ, 1997), a ausência de guarda chuva é interpretada como falta de defesas, em outras palavras, evidencia a fragilidade ou impossibilidade do indivíduo em empregar seus recursos defensivos diante das ameaças do meio ${ }^{14}$.

Vagostello (2007) chama a atenção para a existência de diferenças culturais que podem trazer outras interpretações para a ausência do guarda chuva. Em contato com pesquisadores sul americanos, a autora aponta para pelo menos dois fatores: 0 fato de adolescentes não gostarem de usar guarda chuva e a chuva estar associada a algo bom (por exemplo, para aqueles que vivem em regiões onde a estiagem é muito intensa).

Agosta, Colombo e Barilari (2001/2006), realizaram um estudo para investigar as características gráficas mais comuns do teste da Pessoa na Chuva, em crianças vitimizadas. Esse estudo comparou 81 crianças com histórico comprovado de violência intrafamiliar e 70 crianças da população geral e encontrou frequências estatisticamente significativas de algumas características gráficas do grupo de crianças vitimizadas ${ }^{15}$. Para as autoras, essas características podem ser consideradas possíveis indicadores de situação de violência doméstica, pois estão associadas a manifestações clínicas presentes na literatura especializada como queixas somáticas, retraimento, sentimentos de inadequação, isolamento e dificuldade de expressar afeto (AGOSTA; COLOMBO; BARILARI, 2001/2006).

O próprio acolhimento pode ser uma situação de tensão que mobiliza as defesas dos abrigados. Além disto, as questões que os levaram ao afastamento da família podem estar mais ou menos elaboradas, podendo causar estresse e angústia

\footnotetext{
${ }^{13}$ As principais categorias e interpretações da chuva encontram-se no Anexo B.

${ }^{14}$ As principais categorias e interpretações do guarda chuva encontram-se no Anexo C.

${ }^{15}$ Indicadores projetivos de vitimização e suas interpretações a partir do teste do Desenho da Pessoa na Chuva no Anexo D.
} 
independente do tempo de institucionalização. Do ponto de vista profilático e terapêutico, torna-se interessante divisar se existem defesas (simbolizadas pelo guarda chuva) que protejam o self das crianças e adolescentes que participaram das oficinas e no caso da presença, como elas se apresentam.

\section{Teste das Fábulas de Düss}

O Teste de Fábulas (DÜSS, 1986), foi criado pela psicanalista suíça Louise Düss em 1940, e chegou ao Brasil em 1987 (TARDIVO, 1998). É uma técnica voltada à população infantil (a partir dos três anos), embora possa ser aplicado eventualmente em adultos.

Consiste em pequenas fábulas em que um herói (uma criança ou um animal) encontra-se numa determinada situação que representa um estágio de evolução inconsciente $^{16}$. O conflito vivido pelo herói da história poderá desencadear uma cadeia associativa no examinando, que se explicitará em respostas simbólicas ou demonstrações de resistência, dando indícios do complexo ao qual estaria fixado. Por meio das fábulas, a criança pode expressar seus temores, suas necessidades e seus pensamentos de uma maneira indireta, uma vez que os atribui aos heróis da história (TARDIVO; PINTO JUNIOR, SANTOS, 2005).

Serafini, Ávila e Bandeira (2005) realizaram um estudo em que compararam respostas de crianças abrigadas e uma amostra padronizada no Teste das Fábulas. Verificaram que as crianças abrigadas da amostra apresentaram respostas comuns diferentes do grupo composto por crianças da população geral. As fábulas nas quais foram obtidas respostas diferentes foram: 2,4,5,6,8 e 9. Para a amostra de crianças institucionalizadas, o conteúdo das respostas refletiam situações de privação, abandono e rejeição, o que, segundo as autoras, refletem a sua própria realidade. As pesquisadoras ressaltam que, ao trabalhar com crianças abrigadas, os psicólogos devem se ater para estas diferenças a fim de evitar interpretações precipitadas e equivocadas.

\footnotetext{
${ }^{16}$ Fábulas encontram-se no Anexo $\mathrm{E}$.
} 
Assim, o Teste das Fábulas, por se tratar de uma técnica projetiva, propicia uma investigação profunda sobre os conflitos vivenciados pela criança e da forma como avalia a relação intrafamiliar. Nesse sentido, sua inclusão no processo psicodiagnóstico de crianças revela-se extremamente rica para o conhecimento e entendimento do funcionamento mental dos sujeitos, podendo se mostrar eficaz na investigação clínica de crianças abrigadas.

\section{Inventário de Frases no Diagnóstico de Violência Doméstica (IFVD)}

É um instrumento de grande serventia pela escassez de técnicas de investigação voltado à detecção da vivência de vitimização. Foi criado na Argentina por Agosta, Barilari e Colombo (2001/2006) e adaptado para a população Brasileira por PINTO JÚNIOR; TARDIVO (2010).

O IFVD é um instrumento qualitativo (inventário de auto-descrição), recentemente publicado no Brasil (PINTO JÚNIOR; TARDIVO, 2010) elaborado a partir das expressões verbais mais utilizadas pelas crianças e adolescentes (entre 07 e 16 anos) vítimas de violência física e/ou sexual e que objetiva avaliar transtornos nas esferas: emocional, cognitiva, social, física e comportamentos observáveis na clínica (PINTO JÚNIOR; TARDIVO, 2010). O instrumento parte de duas hipóteses: a primeira é a de que toda criança que foi vítima de violência doméstica sofre um dano psíquico, que se expressa por meio de suas representações gráficas e de seu comportamento. A segunda hipótese é que em função do dano sofrido, estruturará seu aparelho psíquico de uma maneira particular que a leva a distorções perceptivas que dificultam o desenvolvimento pessoal adaptado e evolutivo (PINTO JÚNIOR; TARDIVO, 2010).

O instrumento é composto por 57 frases $^{17}$ e reflete o que a criança e o adolescente percebem de sua realidade, colocando o sujeito frente a situações domésticas que sugerem a experiência de vitimização. Os estudos estatísticos (PINTO JÚNIOR; TARDIVO, 2010) com o inventário de frases na população

\footnotetext{
${ }^{17}$ As frases do IFVD podem ser encontradas no Anexo F.
} 
argentina concluem que este instrumento permite descriminar as crianças vitimizadas daquelas não vitimizadas, mostrando-se sensível, então, na identificação e diagnóstico de crianças e adolescentes em situação de violência doméstica, bem como os transtornos associados a esta experiência: transtornos emocionais, físicos, comportamentais, cognitivos e sociais $^{18}$. E desta forma, contribuindo para o planejamento do processo interventivo e psicoterapêutico. Os autores propõem 22 pontos como sendo o ponto de corte, ou seja, acima desta pontuação o resultado aponta para a existência de indícios de vitimização.

Como mencionado na introdução deste trabalho, a violência doméstica um dos principais motivos leva ao acolhimento (IPEA, 2003; AASPTJ-SP; NCA-PUC-SP; SAS; FUNDAÇÃO ORSA, 2003). Devido a este dado, é interessante avaliá-lo na população estudada, uma vez que traz uma série de consequências a todas as esferas do desenvolvimento.

\section{Children Depression Inventory (CDI)/Questionário de Depressão Infantil}

O CDI foi elaborado por Kovacs (1983) a partir da adaptação do BDI (Beck Depression Inventory) e propõe mensurar sintomas depressivos em jovens de 7 a 17 anos. O instrumento pode ser auto-aplicado ou preenchido por respostas de informantes (pais, amigos ou professores). É constituído por 27 itens com três possibilidades de respostas e a criança deve escolher a opção que melhor descreve o seu estado nos últimos tempos ${ }^{19}$. O ponto de corte foi estabelecido em 17 pontos (BARBOSA; LUCENA,1995). Foi adaptado e normatizado para a cidade de João Pessoa por Barbosa et al. (1995), tido como um instrumento com características psicométricas que satisfaz as condições para discriminar crianças com quadros depressivos, medindo, ainda, a severidade da depressão. Para tanto, avalia a disforia, pessimismo, auto estima, desprezo, isolamento social, rendimento escolar, conduta social e sintomas vegetativos (BARBOSA et al., 1995).

\footnotetext{
${ }^{18}$ Indicação dos transtornos por questão do IFDV no Anexo G.

${ }^{19}$ Os itens do Questionário de Depressão Infantil podem ser encontrados no Anexo H.
} 
Existem fatores de risco e proteção para o surgimento de depressão ao longo do desenvolvimento. A falta de apoio familiar tem sido o principal fator relacionado a manifestações do transtorno depressivo (DELL'AGLIO; HUTZ, 2004). Por outro lado, um contexto familiar que se caracterize por trocas afetivas, intimidade $e$ comunicação apropriada, tem sido identificado como um importante fator de proteção, ajudando as crianças a manterem um senso de estabilidade e rotina frente a mudanças (HERMAN-STAHL; PETERSEN, $1996^{20}$ apud DELL'AGLIO e HUTZ, 2004), mesmo que o relacionamento positivo seja apenas com um dos pais (PTACEK, 1996 ${ }^{21}$, apud DELL'AGLIO e HUTZ, 2004).

Em sua tese de Mestrado, Abreu (2000) investigou a prevalência de transtornos psiquiátricos em crianças institucionalizadas e concluiu que crianças e adolescentes institucionalizados têm maior chance de apresentar transtornos psiquiátricos quando comparados àqueles que vivem com suas famílias. A própria autora ressalta que o fato de suas vidas serem marcadas por eventos adversos (vitimização, miséria, abandono, etc.) pode estar por trás desses achados.

Na medida em que a depressão é um transtorno tão presente em crianças e adolescentes abrigados, o uso de um instrumento específico para este aspecto torna-se justificado ao passo que visa à investigação de uma sintomatologia que pode trazer tantos prejuízos ao desenvolvimento.

\section{Oficinas terapêuticas}

Terminado este primeiro momento diagnóstico foram realizadas doze sessões e pensou-se que seria mais eficiente a proposta de um desenho temático no primeiro encontro. $O$ intuito desta proposta reside no fato de se propiciar um ambiente menos persecutório para que os participantes se soltassem ao longo da tarefa.

\footnotetext{
${ }^{20}$ HERMAN-STAHL, M. \& PETERSEN, A. C. The protective role of coping and social resources for depressive symptoms among young adolescents. Journal of Youth and Adolescence, 25, p.733-753. 1996.

${ }^{21}$ PTACEK, J. T. The hole of attachment in perceived support and the stress and coping process. In. G. R. Pierce, B. R. Sarason \& I. G. Sarason (Orgs.), Handbook of social support and the family, New York: Plenum Press p. 495-520. 1996.
} 
Partindo-se do pressuposto que a experiência do acolhimento é o ponto central para este trabalho considerou-se que o tema deste desenho deveria ser: "Minha vida no abrigo". O procedimento de Desenho Temático favorece o entendimento de uma determinada situação a partir do ponto de vista do autor do desenho. Aiello-Vaisberg (1997) considera Procedimento de Desenhos com Tema muito interessante para o estudo das representações sociais. $O$ viés social reside no fato de, através da representação gráfica e das verbalizações consequentes, se abre um campo para a compreensão de como aquele sujeito, em seu grupo, significa determinada conduta ou situação, que pode ser fonte ou contribuir para o sofrimento psíquico (TARDIVO, 2007). A partir daí é possível conceber intervenções clínicas pertinentes.

Esperava-se que diversas representações que orbitam a temática do abrigo surgissem neste primeiro contato e pudessem ser desdobradas e desenvolvidas nas próximas oficinas. A motivação para os desenhos seguintes partiriam dos próprios participantes não havendo tema.

Para a realização das oficinas foram necessários materiais gráficos: papel, lápis de cor e grafite, tinta guache e pincéis. Elas se deram no refeitório, um espaço amplo e arejado, com mesa grande adequada à prática.

Após a realização dos desenhos, a cada encontro, eles eram organizados numa parede onde ficaram à vista de todos os participantes para então conversarmos a respeito. Em seguida, era tirada uma foto dos desenhos/pinturas, sem a exposição de qualquer membro do grupo. A identidade de todos será preservada na ocasião das fotos e da dissertação em si. As fotos tinham como único objetivo o anexo a esta dissertação para a apresentação das produções e a posterior discussão.

Após o exame de qualificação, foi sugerido que nos encontros restantes (apenas mais dois) realizasse desenhos coletivos com o intuito de trabalhar a relação de todos como um grupo. Então, no décimo primeiro e décimo segundo encontros, foi seguida a sugestão e foram propostos desenhos coletivos numa cartolina. 


\section{APRESENTAÇÃO DOS PARTICIPANTES E PSICODIAGNÓSTICOS COMPREENSIVOS}

Como este estudo possui dois focos como já explicitado, dedicamos este capítulo à apresentação, conhecimento e compreensão dos participantes do grupo. Assim, a seguir, serão apresentados dados recolhidos em entrevistas individuais e com o auxílio dos instrumentos psicológicos.

No caso de Roberto, realizou-se apenas uma entrevista, pois, o objetivo, era conhecer a forma como pensava e se via no abrigo. Sua participação se deu em função da solicitação da coordenadora do abrigo para que a Oficina colaborasse na relação entre as meninas e a equipe institucional, através do desenvolvimento de uma compreensão mais ampla de cada uma. Desta forma, não se configurou um objetivo deste trabalho a realização de um diagnóstico com Roberto.

A entrevista com ele se dividiu em dois momentos: no primeiro, foram investigados dados acerca da sua experiência pessoal e num segundo, recolheramse informações sobre as meninas que participariam da atividade. A escolha por Roberto para a obtenção de dados sobre as meninas veio da própria coordenadora da instituição que o indicou por estar no abrigo há mais tempo e, portanto, ter maior conhecimento da história de cada uma.

Já com as meninas participantes, os dados elencados na sequência dizem respeito às informações fornecidas por Roberto, e por elas próprias tanto na entrevista individual como através das produções nos instrumentos de exame utilizados. Com os dados apreendidos, realizamos uma síntese de compreensão clínica sobre cada participante.

Os relatos das entrevistas e da Oficina estão em primeira pessoa do singular, diferente do conteúdo anterior deste trabalho. Esta mudança na expressão escrita visou à aproximação da pesquisadora, também autora desta dissertação, dos participantes. Partindo do pressuposto que também era parte integrante do processo que se estabeleceu desde os primeiros contatos. 


\section{ROBERTO ${ }^{22}$ - cuidador}

\section{a) Entrevista}

Roberto é funcionário da Prefeitura deste Município da Grande São Paulo desde 2008. Por reestruturação de cargos foi transferido para trabalhar em um abrigo masculino em 2009. No início, muitos funcionários que haviam sido transferidos como ele "não aguentaram" e pediram demissão.

Ressaltou que neste abrigo, não era permitido ter contato com os abrigados. A equipe dirigente reforçava o tempo todo que deveria haver uma separação, que "ninguém tinha que ser amigo de abrigado". Isso durou dois meses e logo a coordenação do abrigo passou para a atual coordenadora. Então Roberto relata que as coisas mudaram completamente: as regras ficaram mais severas em relação ao consumo de drogas, cigarros e a higiene da casa. Esta coordenadora começou a incentivar a afetividade entre os funcionários e os jovens. Roberto gosta de salientar que é necessário manter certa distância para não desvirtuar sua autoridade, mas também pode ser carinhoso. Diz que é preciso ser firme, sem levar tudo "a ferro e fogo".

Em 2010 quase não havia mais crianças no abrigo. Todas tinham sido encaminhadas para a família ou adotadas. $\mathrm{O}$ abrigo estava prestes a encerrar suas atividades, quando outra instituição fechou e as crianças e adolescentes foram então encaminhados para o abrigo onde Roberto trabalhava. Conta que no início foi muito difícil porque os abrigados não tinham qualquer respeito pelas regras, pois, vinham de um ambiente completamente permissivo. A dificuldade maior era um grupo de meninos mais velhos, prestes a completar 18 anos que resistiam mais fortemente às mudanças e incitavam outros adolescentes e crianças a se rebelarem. Roberto conta que tinha medo destes meninos, mas tinha que se manter firme. Chegou até ser ameaçado de morte.

\footnotetext{
${ }^{22}$ A fim de preservar a identidade dos participantes, todos os nomes são fictícios.
} 
Conforme estes meninos atingiram a maioridade civil, saíram e a casa foi se tranquilizando. Transferiram as crianças pequenas para outro abrigo e ficaram apenas com as maiores (no momento da pesquisa havia dois bebês na casa). Diz que a coordenadora apostou na equipe. Alguns dos educadores antigos foram demitidos, pois não desempenhavam o seu papel de forma ética. Disse que é muito gratificante ter o respeito das crianças hoje.

Vê que o seu papel é incentivá-los a fazer cursos, ir à escola, porque assim está preparando-os para quando saírem de lá. Consequentemente, sua maior dificuldade ocorre quando os abrigados não aceitam esses incentivos e não querem construir "coisas boas".

Trabalha com horário fixo, de segunda a sexta, mas confessa que fica muito preocupado com a casa abrigo aos finais de semana. Isso porque, aqueles funcionários que julga serem os mais firmes, não estão presentes. Assim, telefona mesmo estando de folga para saber se está tudo bem.

Durante a entrevista seu celular toca e ele diz que é um ex abrigado. Conta que, muitos, depois que saem do abrigo, ligam quando precisam de alguma coisa, ou só para conversar. Alguns chegam até a ir visitar o abrigo. Sabe que uma parte deles foi presa e outros foram mortos, mas continua tendo notícia dos que estão "encaminhados", trabalhando, vivendo com a família. Diz que gosta muito do seu trabalho e não se vê fazendo outra coisa.

\section{GABRIELA - criança abrigada}

\section{a) Entrevista com Roberto}

Gabriela atualmente está com 10 anos. Das integrantes do grupo é a que estava há menos tempo no abrigo: apenas três meses. Foi abrigada por uma denúncia que revelou a existência de um relacionamento entre Gabriela e um rapaz de 23 anos, consentida pelos pais dela. Assim que chegou ao abrigo ficou muito agitada, querendo falar com a mãe, ver a família. Contava para as outras meninas 
da casa suas experiências sexuais com o "namorado" (para indignação dos funcionários da casa, era assim que Gabriela tratava o rapaz).

Os pais e o "namorado" foram até o abrigo e "fizeram escândalo" na frente da casa pedindo para ver a menina. O mesmo se dava na escola. $O$ irmão mais novo de Gabriela, algumas vezes, entregava a ela, cartas do rapaz. Diante dessa aproximação, a juíza determinou que Gabriela fosse afastada temporariamente da escola sob pena de prisão tanto dos pais e do namorado, caso quisessem se aproximar, quanto da coordenadora do abrigo, caso permitisse. Quando isto foi explicado à Gabriela, ela simplesmente parou de insistir para ver a família e deixou de falar no assunto.

A mãe disse que Gabriela começou a menstruar aos 9 anos. Na época que coincide com o início desta pesquisa, a equipe do abrigo estava muito preocupada, pois desde que chegou, a menina ainda não menstruara, sendo que sua barriga "não parava de crescer". Havia uma suspeita de que ela estivesse grávida. Gabriela, por sua vez, se recusava a fazer qualquer exame: de sangue ou ginecológico.

Depois de alguns dias da realização desta entrevista, aceitou ir ao médico e não foi constatada gravidez nem qualquer problema de saúde.

\section{b) Entrevista com Gabriela}

Gabriela é a primeira a vir espontaneamente para a entrevista. Inicialmente, fico impressionada ao saber a sua idade, que não condizia com a sua estrutura física. É uma menina alta e com o corpo de mulher bem formado para uma criança de 10 anos. Durante a entrevista e a aplicação dos instrumentos, alternava momentos em que transparecia apreensão e em outros soltava risadas exageradas e constrangidas. Após ser esclarecida sobre como se daria a oficina, aceita participar.

Conta que não está indo para a escola, passa o dia no abrigo sem ter muito que fazer. Gosta de assistir televisão, mas se queixa que no abrigo não tem televisão a cabo, como na sua casa. Sobre o motivo do seu acolhimento, responde 
que não sabe a razão de estar ali. Diz que não gosta dali porque está longe daqueles que ela ama. Não faz qualquer menção ao "namorado".

Ela e a família são migrantes nordestinos. Conta que tem um irmão mais velho que mora no nordeste com a avó e outro mais novo que mora com os pais.

c) Procedimentos com Gabriela

Tabela 2 - Produções gráficas de Gabriela

Desenho da Figura Humana Desenho da Pessoa na Chuva


Tabela 3 - Respostas de Gabriela ao Teste das Fábulas

I. Fábula do pássaro

II. Fábula do Aniversário de Casamento

III. Fábula do carneirinho

IV. Fábula do enterro

V. Fábula do medo

VI. Fábula do Elefante

VII. Fábula do Brinquedo Fabricado

VIII. Fábula do passeio com o pai

IX. Fábula da notícia

X. Fábula do sonho mau
Vai voar para cima, para as plantas.

Porque a festa está sendo no fundo do quintal e ela quer participar.

Vai comer grama. Porque sua mãe mandou.

Um vizinho. Estava doente da perna.

De bicho, de vampiro, de lobisomem.

O jeito. Ele tava triste, agoniado, sem conversar com ninguém. Porque não tinha ninguém.

Vai dar [a torre] para a mãe.

Porque ela estava cansada de trabalhar, de limpar a casa.

Que vai buscar a filha na escola.

Com vampiro, teve pesadelo.

\section{Tabela 4 - Pontuações de Gabriela no IFVD e CDI}

\begin{tabular}{c|c|c} 
& $\begin{array}{c}\text { Pontuação IFVD } \\
\text { (ponto de corte = 22) }\end{array}$ & $\begin{array}{c}\text { Pontuação CDI } \\
(\text { ponto de corte = 19) }\end{array}$ \\
\hline Gabriela & 33 & 19 \\
\hline
\end{tabular}

\section{Compreensão Clínica}

Durante a aplicação do CDI e do IFVD, Gabriela, diversas vezes perguntava "como assim?" diante das afirmações dos procedimentos. Num primeiro momento é aventada a hipótese de algum déficit cognitivo, mas ao longo da aplicação observase que, ao pedir que eu explicasse melhor as perguntas/afirmações, esperava de mim alguma dica de qual seria a resposta correta. Em diversos momentos, faz 
comentários do tipo: "É assim que tenho que responder?". Parece haver uma dificuldade de se expressar de forma autêntica o que se sente, buscando formas de adaptação às expectativas externas.

Sua pontuação no IFVD encontra-se acima do ponto de corte (33 pontos, sendo o ponto de corte $=22$ ), o que nos indica a ocorrência de violência doméstica, condizente com o motivo de seu acolhimento: o relacionamento sexual com um rapaz de 23 anos com o consentimento de sua família. Entre os índices (cognitivo, emocional, social, comportamental e físico), aquele que Gabriela teve a maior pontuação foi o emocional: 15 pontos de um total de 18 possíveis. O que nos fala a respeito do grau de comprometimento emocional da menina.

Algumas respostas do IFVD ${ }^{23}$ refletem o estabelecimento de um vínculo ambivalente com as figuras parentais que não são vistas como dignas de confiança. Ao mesmo tempo, queixa-se muito de saudades dos pais. Essa ambivalência também é constatada na primeira fábula, quando diz que o passarinho filhote não voará para a árvore de nenhum dos pais.

Roberto contou que Gabriela relata abertamente os atos sexuais que realizou com o "namorado", deixando as outras meninas e funcionários chocados pela forma "natural" com a qual se expressava. No entanto, durante a entrevista, não tocou em nenhum assunto deste tema. Esta questão surge de forma simbólica nas respostas dadas na Fábula V e X. Gabriela personaliza seu medo em figuras como o vampiro e o lobisomem, alegorias fantásticas, que remetem ao masculino e à sexualidade com caráter persecutório oral. No IFVD, deu respostas que nos ajudam a compreender seu estado emocional neste ponto. No inventário, respostas como: "Sinto meu corpo usado"; "Penso que sexo é algo mau"; "Me sinto suja por dentro"- nos apontam para o conflito e sofrimento oriundos destas experiências sexuais precoces.

Esta posição aparentemente contraditória (falar abertamente das relações sexuais e o sofrimento que isto traz) pode ser entendida como consequência de uma defesa psíquica primitiva: a cisão. Respostas ao IFVD ${ }^{24}$ confirmam tal mecanismo

\footnotetext{
23 "Às vezes penso que minha mãe vai me abandonar". "Não gosto de ficar sozinha com meu pai". "Não gosto de ficar sozinha com a minha mãe". outra pessoa"

24 "Parece que eu estou dormindo quando me acontecem coisas feias", "Conto minha história como se tivesse acontecido com
} 
que tem como objetivo proteger o ego de Gabriela das invasões do meio ambiente e dos sentimentos intensos que não consegue lidar. Esse aspecto pode ser visto no comportamento da menina que alternava de forma impactante momentos de profunda apreensão e medo com risadas maníacas.

Desta forma o fato de relatar abertamente para quem quisesse ouvir suas experiências sexuais não significa que ela encarasse tudo com naturalidade, muito pelo contrário. A Fábula VI nos mostra o quanto a menina encontra-se angustiada. Ao contar por que o elefante teria mudado, Gabriela diz que ele está triste, agoniado, sem conversar com ninguém, porque não tem ninguém. Ao falar do animal, a menina fala de si mesma. Do quanto se vê sozinha num ambiente estranho de onde não pode sair (está proibida judicialmente até de ir à escola) e onde não tem ninguém em quem confie.

Seu sofrimento também aparece no IFVD quando dá respostas como: "Tenho medo que me machuquem"; "Os barulhos me assustam"; "Eu estou louca"; "Quase sempre tenho pesadelos"; "Tenho medo de contar o que acontece comigo".

Nos desenhos, a angústia é expressa pelo tamanho diminuto das figuras $(2,5$ cm - DFH e $3 \mathrm{~cm}$ Desenho da Pessoa na Chuva), pelo empobrecimento da figura humana desenhada de forma esquemática e sem roupas, assim como pelo posicionamento no canto inferior esquerdo do DFH. No desenho da Pessoa na Chuva, Gabriela mostra-se identificada com um menino de 9 anos totalmente à mercê da chuva intensa e setorizada sobre a figura, o que indica a grande pressão sentida. Não apresentou qualquer forma de defesa frente a estas tensões. Além disso, a ausência de boca neste menino pode nos indicar a dificuldade de comunicação do que se passa com ela, como na Fábula do Elefante, em que ele está triste, sem ter com quem conversar.

Apesar de ter obtido uma pontuação limite no CDI (17 pontos). $\mathrm{O}$ alto grau de angústia vivida por Gabriela bem como o uso de mecanismos de defesa muito primitivos e que não dão conta da agonia vivida, inspirou muita atenção.

\section{MAIARA - adolescente abrigada}




\section{a) Entrevista com Roberto}

Com treze anos, Maiara cursava na série regular na escola. Estava no abrigo desde 2007 (abrigada aos 9 anos). Segundo Roberto, seu pai é desconhecido e a mãe é alcoolista, possuindo um irmão mais velho que chegou a desabrigá-la por um momento, mas como teve que trabalhar, deixava a menina com a mãe. Como esta não tinha condições de cuidar da menina, Maiara foi abrigada novamente. Numa ocasião, Maiara chegou a agredir a mãe para impedir que bebesse.

Josi e Maiara se conhecem desde o abrigo anterior, de onde vieram quando a instituição fechou.

Hoje, a mãe de Maiara faz tratamento num CAPS AD e vê a filha duas vezes por semana: busca-a na escola e a leva para o abrigo. Possuem um bom relacionamento. O irmão já havia entrado em contato com a coordenação, solicitando que a irmã passasse as festas de final de ano com a família (entrevista realizada no início de novembro). É tida por Roberto como uma menina bem reservada, não conversa muito, não se abre. A coordenadora já demonstrou preocupação acerca do que há no interior de Maiara e receio de como isto pode "sair".

\section{b) Entrevista com Maiara}

Maiara se mostra muito educada. Prestou muita atenção em tudo o que lhe foi explicado sobre a pesquisa e consentiu em participar. Possui um olhar tristonho, fala pouco e tem uma postura contida.

Apesar disto, falou abertamente da sua questão familiar. Contou-me que sua mãe é alcoolista e que sente muitas saudades daqueles que ama. Ao mesmo tempo, reconhece a necessidade do afastamento do lar para poder ser "um pouco mais feliz". Aposta fortemente na recuperação da mãe.

Conta que conhece Josi desde o outro abrigo e que são amigas. 
Possui quatro irmãos, sendo que conhece apenas um deles: seu irmão mais velho que é casado e está tentando desacolhê-la.

\section{c) Procedimentos com Maiara}

Tabela 5 - Produções gráficas de Maiara

\begin{tabular}{|c|c|c|}
\hline Desenho da Figura Humana Desenho da Pessoa na Chuva \\
Desenho da Figura Humana de Maiara. \\
Menino de 13 anos.
\end{tabular}

No Teste das Fábulas, Maiara deu as respostas muito curtas, como vemos na tabela a seguir.

Tabela 6 - Respostas de Maiara ao Teste das Fábulas
I. Fábula do pássaro
Vai seguir o pai.
II. Fábula do Aniversário Porque foi pegar flores para dar à mãe.
de Casamento
III. Fábula do carneirinho Ele vai obedecer à mãe.
IV. Fábula do enterro Uma idosa. Morreu de ataque do coração.
V. Fábula do medo Da noite escura, porque ela vê bichos. 

VI. Fábula do Elefante
O elefante cresceu porque comeu muito.
VII. Fábula do Brinquedo
Ela vai ficar com a torre.

Fabricado

VIII. Fábula do passeio

Porque eles demoraram e ela ficou preocupada. com o pai
IX. Fábula da notícia
Fala que o filho tem que melhorar a nota na escola.

X. Fábula do sonho mau Ela estava caindo num buraco sem fim.

\section{Tabela 7 - Pontuação de Maiara no IFVD e no CDI}

\begin{tabular}{c|c|c} 
& $\begin{array}{c}\text { Pontuação IFVD } \\
\text { (ponto de corte = 22) }\end{array}$ & $\begin{array}{c}\text { Pontuação CDI } \\
\text { (ponto de corte =17) }\end{array}$ \\
\hline Maiara & 19 & 13 \\
\hline
\end{tabular}

\section{Compreensão clínica}

Tanto no IFVD como no CDI, Maiara apresentou uma pontuação que se situa abaixo dos respectivos pontos de corte. No caso do IFVD, a média do grupo controle na normatização foi 14 pontos (PINTO JÚNIOR; TARDIVO, 2010), de modo que, apesar de não ultrapassar o ponto de corte, Maiara fez mais pontos do que a média das crianças e adolescentes que não sofreram vitimização.

A menina se mostrou muito solícita, mas, ao mesmo tempo, muito reservada, o que nos aponta suas respostas rápidas e curtas no Teste das Fábulas. Esta postura Na última Fábula, Maiara se mostrou um pouco mais, revelando já ter tido o pesadelo de estar caindo num buraco sem fim. Esta imagem nos remete a um dos tipos de ansiedades primitivas descrita por Winnicott (2006) como "cair para sempre" que diz respeito a um sentimento de falta de contorno e de apoio. Na fábula $\mathrm{V}$, temos uma resposta também infantilizada, dando indícios do quanto pode ser tomada por angústias infantis.

A dificuldade de lidar com os conflitos é evidenciada pela ausência de chuva no Desenho da Pessoa na Chuva. De acordo com as instruções de aplicação deste 
teste, a chuva é claramente verbalizada pelo aplicador no momento da proposição. Desta forma, a opção de Maiara em ignorar este dado em seu desenho nos mostra uma postura ativa como sujeito diante do que a chuva representa simbolicamente: uma tensão ou hostilidade do meio da qual é preciso se defender. No caso, Maiara não mostrou condições mais efetivas de defesa, ao não representar o guarda chuva ou qualquer outro aparato que protegesse a figura humana. $O$ fato de não se ver em condições de se defender de tais angústias aponta para uma tendência em negar os conflitos (não representação da chuva).

Quando comparamos o Desenho da Figura Humana à Pessoa na Chuva, vemos no primeiro a existência de mais detalhes na vestimenta. A figura masculina surge um pouco mais estruturada para a menina. Na Fábula I, Maiara nos conta que o passarinho filhote seguiu o pai. Não tendo conhecido seu pai, seu irmão mais velho assumiu uma figura paterna acolhedora. Tanto que é descrito por Roberto como uma pessoa muito interessada em desacolher a irmã e levá-la para casa a cada oportunidade. Em contrapartida, embora a mãe seja considerada mais frágil por causa do alcoolismo, a relação com a figura materna apresenta-se nas fábulas II, III,VIII e IX de forma adequada. A mãe é tida como uma pessoa por quem Maiara nutre grande afeto e demonstra cuidado com a filha. Esse aspecto vai ao encontro do que nos contou Roberto sobre o bom relacionamento entre Maiara e a mãe, que se veem duas vezes por semana.

Como relatou Roberto, Maiara é de fato muito reservada, sendo muito difícil acessar o que se passa em seu interior. Porém, a ansiedade primitiva que surge na Fábula $\mathrm{X}$, o uso de estratégias como o isolamento e o distanciamento para dar conta de angústias além da sua dificuldade em possuir mecanismos de defesa frente a situações estressantes, reforçam a preocupação que a coordenadora do abrigo expressa sobre o que há no interior de Maiara.

\section{JOSI - adolescente abrigada}

\section{a) Entrevista com Roberto}


Roberto e Josi possuem um bom relacionamento. Ela está no primeiro ano do ensino médio (possui 16 anos).

Tem um irmão que está abrigado com ela e além deste, possui outros 5 irmãos mais velhos que já foram adotados com os quais não têm contato por recusa das respectivas famílias substitutas. Josi manifestava intenso desejo de ver os irmãos, mas diante da proibição não tocou mais no assunto.

Durante o período de acolhimento, chegou a morar com a mãe, mas esta a levou de volta para o abrigo por causa de seu comportamento. As duas tinham conflitos constantes e Josi não obedecia à mãe. Houve duas tentativas de ser inserida em famílias substitutas, mas em ambos os casos foi devolvida ao abrigo por mau comportamento que consistiam em atitudes de enfrentamento e resistência a seguir as regras da casa.

É muito aplicada na escola e, segundo Roberto, tem o sonho de sair do abrigo, alugar uma casa, se sustentar e desacolher o irmão de 14 anos.

A mãe visitava os filhos com certa frequência, mas há algum tempo não tem comparecido. Tanto Josi quanto o irmão demonstravam interesse nas visitas da mãe, pois esta trazia sempre presentes. A coordenadora do abrigo pediu que a mãe não correspondesse a essa relação comercial trazendo presentes em todas as visitas. Pelas falas de Josi, fica implícito que a mãe seria prostituta.

É descrita como uma menina tranquila, que cumpre as tarefas da casa, vai à escola normalmente e tira boas notas. Às vezes fica rebelde, porém respeita a autoridade.

Josi se envolveu com um rapaz de outro abrigo muito agressivo (agredira uma educadora e a própria mãe). Há poucos meses ficou internado em uma clínica de reabilitação por uso de drogas. A coordenadora do abrigo de Josi a proibiu de ter contato com ele até que se tratasse. No início, Josi foi muito resistente, mas, cerca de um mês depois, parou de falar no assunto. 


\section{b) Entrevista com Josi}

Explico a Josi sobre a pesquisa e pergunto se gostaria de participar. Ela aceita, mas durante a entrevista mostra-se um pouco desconfiada e séria. Quase não olhava para mim e por várias vezes fazia comentários tão baixos que era impossível ouvir. Conta que está abrigada desde os 7 anos.

Contou que a mãe é garota de programa. Um dia, seu pai disse a ela que, se não "largasse a vida" ele a denunciaria ao Conselho Tutelar e ela perderia os filhos. Foi isso que fez e Josi e os irmãos foram abrigados. O pai nunca mais foi visitá-los. Josi conta isto com aparente indiferença, não assume sentir falta do pai ou ter o desejo de voltar a vê-lo, pelo contrário, prefere nunca mais encontrá-lo. Parece ter certa mágoa da mãe. Diz não querer mais morar com ela demonstrando que a sua opção é trabalhar, pagar o aluguel de uma casa e desabrigar o irmão.

Josi relata que logo em seguida ao seu acolhimento, foi adotada por uma família, mas ela não quis ficar lá. Voltou ao abrigo e não queria mais ser adotada. Até que uma família interessou-se por seu irmão. Como ele apresentou vontade em ser adotado, Josi respeitou sua decisão e também foi com ele morar com uma família substituta (política de não se separarem irmãos). Mas o irmão não gostou da experiência e mais uma vez a adolescente voltou ao abrigo.

Não se diz boa aluna e muito menos gostar da escola. Vê nos estudos a única chance de conseguir construir o que precisa quando tiver que sair do abrigo, por isso dedica-se minimamente na escola.

Quando pergunto se tem namorado, Josi me conta que se interessou por um menino há alguns meses. Ele era abrigado em outra unidade e se envolveu com drogas, chegando a ser internado numa clínica. Segundo Josi, a coordenadora do abrigo conversou com ela e explicou que não consentia no relacionamento, mas que a decisão era dela (Josi), que ela deveria escolher o que era melhor para si. Josi optou por se afastar deste rapaz, mas fala de forma ressentida ao dizer que a coordenadora estragou o relacionamento. 
c) Procedimentos com Josi

Tabela 2 - Produções Gráficas de Josi

\begin{tabular}{|c|c|c|}
\hline Desenho da Figura Humana & Desenho da Pessoa na Chuva \\
Desenho da Figura Humana de Josi. \\
Menino de 14 anos.
\end{tabular}

\section{Tabela 9 - Respostas de Josi ao Teste das Fábulas}

I. Fábula do pássaro

II. Fábula do Aniversário de Casamento

III. Fábula do carneirinho

IV. Fábula do enterro V. Fábula do medo

VI. Fábula do Elefante

VII. Fábula do Brinquedo Fabricado
Vai seguir para outra árvore, vai voar para a mais próxima (nem a da mãe, nem a do pai).

Não quer participar da festa ou então vai fazer uma surpresa.

Vai ajudar, vai comer grama. Vai deixar para o mais novo porque já passou por isso.

Um vizinho chato. Morreu de velhice.

De alguém maior que tem cara de mau e pode prejudicar.

O tamanho. Chegou a idade de crescer. Ninguém é pequeno para sempre.

Vai fazer outra e dar para a mãe. 
VIII. Fábula do passeio com o pai

IX. Fábula da notícia

X. Fábula do sonho mau
Achou estranho porque o pai nunca leva a filha para passear. Achou a atitude dele estranha. Pode ser ruim ou não.

Vai lhe dar um presente ou uma bronca.

Uma fantasia louca, coisa que não existe. Essas coisas que falam que existe, mas não existe.

\section{Tabela 10 - Pontuação de Josi no IFVD e CDI}

\begin{tabular}{c|c|c} 
& $\begin{array}{c}\text { Pontuação IFVD } \\
\text { (ponto de corte = 22) }\end{array}$ & $\begin{array}{c}\text { Pontuação CDI } \\
\text { (ponto de corte = 17) }\end{array}$ \\
\hline Josi & 9 & 13 \\
\hline
\end{tabular}

\section{Compreensão clínica}

$\mathrm{Na}$ história de vida de Josi, vemos uma sucessão de tentativas frustradas de desacolhimento, tanto no regresso à casa da mãe, como na inserção em famílias substitutas. Seus retornos ao abrigo, segundo Roberto, foram por mau comportamento. Em contrapartida, na fala de Josi, ela voltou ao abrigo porque não quis ficar nos ambientes que encontrou. Neste caso, o "mau comportamento" revelou um desconforto por parte da adolescente, que relatava ter sido encaminhada para uma família substituta logo em seguida ao seu primeiro acolhimento e sem qualquer explicação.

Apesar de ser descrita como uma pessoa tranquila e solícita, Roberto nos conta que Josi tem seus momentos de rebeldia, o que levando em consideração sua história, pode ser uma forma recorrente de externalizar sentimentos que não sabe expressar de outras maneiras como o desejo de não ser adotada e os "maus comportamentos" que apresentou na época.

Josi se mostra às voltas com muitos sentimentos ambivalentes inclusive no que dize respeito à família. Na fábula I, Josi mostra claramente que não vê os pais como figuras que Ihe trazem segurança. Nas Fábulas VIII e IX, as figuras parentais 
parecem de forma ambígua. A adolescente mostra não saber o que esperar ou o que pensar acerca dos pais: se são bons, ou ruins. Mostra uma dificuldade em integrar os aspectos positivos e negativos dos pais o que reflete na falta de clareza do sentimento que tem por eles. Essa confusão encontra ressonância na história de vida da garota. A mãe, segundo conta, continuou sendo garota de programa, mesmo com a ameaça de perder os filhos. Porém, se esforça para visitá-los e até reparar o dano causado com presentes. O pai, num primeiro momento mostrou-se "protetor" afastando os filhos da mãe que não levava uma "vida adequada". No entanto, nunca mais foi visitá-los.

Elabora as figuras humanas de forma incompleta, ou seja, não desenha o corpo inteiro. No Desenho da Figura Humana, faz a cabeça e o pescoço de um adolescente de 14 anos numa postura oposicionista, com a língua para fora, o que revela imaturidade. Já no desenho da Pessoa na Chuva, representa uma menina com a mesma idade do que ela, com um guarda chuva proporcional ao seu tamanho que a protege das gotas de água. Apresenta-se, neste segundo momento de forma mais madura. A presença de nuvens encostando no guarda chuva nos indica a pressão do ambiente sentida pela adolescente que se esforça para dar conta. Esta oscilação entre maturidade e imaturidade constitui um dos aspectos da forte ambivalência vivida pela adolescente e que colabora para que suas defesas não sejam mais efetivas.

Chama a atenção a fisionomia da garota do desenho que parece estar muito brava. Este aspecto se relaciona com o que foi dito anteriormente sobre Josi e seus comportamentos rebeldes. A elaboração do desenho da Pessoa na Chuva sob este viés reforça a impressão de que a adolescente possa apresentar reações oposicionistas e agressivas diante de tensões externas e internas em relação aos sentimentos que emergem.

Esta tensão pode estar relacionada com as responsabilidades que enfrentará no momento do seu desacolhimento pela chegada da maioridade civil. Na Fábula VI, sua fala expressa o sofrimento oriundo do crescimento irreversível. Vê o elefante como um ser vivo, que está em crescimento, resposta que revela imaturidade, uma vez que, em adolescentes é mais comum ver o elefante como um brinquedo, portanto inanimado. A angústia sentida se expressa na lágrima que escorre do olho 
esquerdo do desenho. Ainda, quando retomamos o que a adolescente nos disse sobre o término do seu namoro, podemos entender que, ao colocar na garota a responsabilidade pela escolha do que seria melhor para ela, a coordenadora, segundo Josi, teria estragado tudo. Podemos inferir que a adolescente não encara a responsabilidade com caráter positivo apesar de verbalizar a necessidade de ter uma casa e se cuidar sozinha.

Josi apresentou pontuações abaixo dos pontos de corte tanto no IFVD como no CDI, o que nos indica não haver indícios de que tenha sofrido violência doméstica ou que possua traços deprimidos, apesar de se mostrar angustiada e sofrida.

\section{SÍNTESE GERAL}

Em relação às meninas que participaram da Oficina de Desenho e Pintura, o acolhimento institucional se deu por motivos diferentes em contextos subjetivos também diversos. Consequentemente, suas experiências diante da vida institucional mostraram-se heterogêneas.

Enquanto Gabriela se via às voltas com a adaptação ao afastamento familiar e à instituição, Josi e Maiara estavam abrigadas há anos e já vinham juntas de um abrigo anterior fechado por não ser um ambiente adequado para o cuidado de crianças e adolescentes.

Da mesma forma, cada uma apresentava uma perspectiva em relação ao desacolhimento: Gabriela não tinha previsão para que isto ocorresse, estando impedida judicialmente de ver a família. Fato que Ihe trazia uma angústia enorme, sendo esta a primeira ocasião em que se afastava da mãe.

Maiara possui uma família presente representada pela mãe, que mesmo passando por um tratamento para superar o alcoolismo, via a filha duas vezes por semana. Tem ainda um irmão mais velho muito interessado em levá-la para morar com ele. Ainda que possua um cenário familiar bastante favorável, Maiara mostrouse retraída, sem conseguir expressar sentimentos que se fizeram perceber de forma sutil. 
Josi, abrigada há mais tempo do que as outras duas meninas, não possuía qualquer perspectiva de voltar a morar com a mãe. Com a aproximação da maioridade civil, sua saída do abrigo se divisava no horizonte de forma compulsória, obrigando-a a assumir certas responsabilidades, com as quais tentava lidar, mesmo sentindo-se muito pressionada.

As entrevistas e os procedimentos psicológicos empregados trouxeram à tona algumas nuances destas experiências evidenciando que, mesmo com diferenças, o acolhimento institucional é acompanhado de sofrimento psíquico tanto pelo motivo que levou ao afastamento das figuras amadas, como a adaptação à vida no abrigo, muito diferente de uma vida em família bem como a perspectiva de saída.

Neste cenário, a figura de um cuidador como Roberto se faz imprescindível. Muito comprometido com sua função, ele teve a participação na oficina muito bem acolhida pelas meninas, principalmente Josi e Maiara, que demonstraram gostar muito dele. $O$ afeto é mútuo, ainda que para o educador não seja claro o limite entre mostrar-se carinhoso e permissivo.

Como todo enquadre grupal e inclusivo, a Oficina de Desenho e Pintura se constituiu por sujeitos únicos que compartilhavam e ocupavam o espaço institucional do abrigo de maneira completamente própria. Essa característica conferiu aos encontros a riqueza que só se dá na intersecção do acontecer humano proveniente de subjetividades singulares. 


\section{RELATO DOS ENCONTROS DA OFICINA EXPRESSIVA DE DESENHO E PINTURA}

A oficina expressiva, por ter tido um caráter inclusivo, contou com a participação flutuante de crianças, adolescentes e cuidadores. Apesar de haver acordado com a direção do abrigo que participariam três meninas e um cuidador, a rotina constantemente cambiante da instituição refletiu-se nas atividades propostas. Abaixo segue um quadro no qual constam as frequências em cada encontro.

Tabela 11 - Presença de cada participante na Oficina

\begin{tabular}{|c|c|c|c|c|c|c|c|c|c|c|c|c|c|c|c|}
\hline & 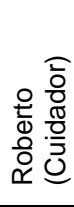 & 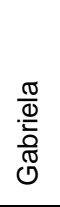 & so & 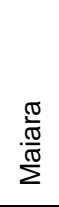 & 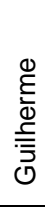 & 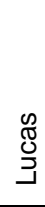 & 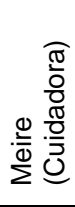 & 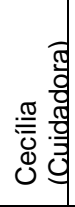 & 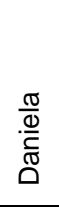 & 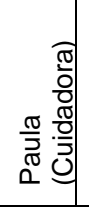 & 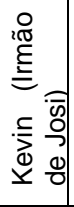 & 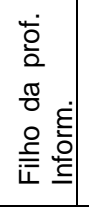 & 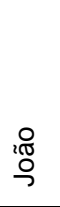 & 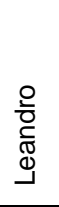 & 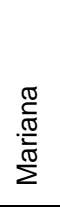 \\
\hline Enc. 1 & $x$ & $x$ & $x$ & $x$ & & & & & & & & & & & \\
\hline $\begin{array}{c}\text { Enc. } \\
2\end{array}$ & $X$ & $X$ & $x$ & $x$ & & & & & & & & & & & \\
\hline $\begin{array}{c}\text { Enc. } \\
3\end{array}$ & & & $x$ & $x$ & & & & & & & & & & & \\
\hline $\begin{array}{c}\text { Enc. } \\
4\end{array}$ & & $\mathrm{X}$ & $x$ & $\mathrm{X}$ & $x$ & & & & & & & & & & \\
\hline Enc.5 & $x$ & $x$ & $x$ & $x$ & $x$ & & & & & & & & & & \\
\hline $\begin{array}{c}\text { Enc. } \\
6 \\
\end{array}$ & & $\mathrm{X}$ & $x$ & & & $x$ & $x$ & $x$ & & & & & & & \\
\hline $\begin{array}{c}\text { Enc. } \\
7\end{array}$ & $x$ & $X$ & $x$ & & & $x$ & & & $x$ & & & & & & \\
\hline $\begin{array}{c}\text { Enc. } \\
8\end{array}$ & $x$ & $x$ & $x$ & & & $x$ & $X$ & $x$ & $X$ & $X$ & & & & & \\
\hline $\begin{array}{c}\text { Enc. } \\
9\end{array}$ & & $x$ & $x$ & $x$ & $x$ & & & & & & $x$ & & & & \\
\hline $\begin{array}{c}\text { Enc. } \\
10\end{array}$ & & & $x$ & $\mathrm{X}$ & $X$ & & & & & & & $X$ & & & \\
\hline $\begin{array}{c}\text { Enc. } \\
11\end{array}$ & & $x$ & $x$ & $x$ & $x$ & & & & & & & & $x$ & & \\
\hline $\begin{array}{c}\text { Enc. } \\
12\end{array}$ & & & $x$ & X & $x$ & & & & & $x$ & $x$ & & $x$ & $x$ & $x$ \\
\hline
\end{tabular}


“Não somos totalmente felizes, mas tudo se 'encacha' (sic)."

A oficina atrasou um pouco porque havia certo tumulto na casa, pois um menino novo acabara de chegar. As meninas foram chamadas por Roberto. Maiara e Josi vieram animadas, conversando, mas não diretamente comigo. Sentam-se à mesa onde os materiais já se encontram disponíveis: papéis de diferentes tamanhos e cores, tinta, lápis de cor e lápis grafite.

Tento iniciar uma conversar informal, ao passo que as meninas respondem timidamente. Introduzo a proposta da oficina: um desenho temático cujo tema seria "Minha Vida no Abrigo". Imediatamente Roberto pega o bloco de papel A3 e pergunta quem vai querer uma folha. Gabriela permanece quieta desde que chegou e não responde à pergunta. As outras meninas pegam uma folha $A 3$ cada $e$ perguntam para Gabriela que folha ela quer. A menina permanece quieta. Não está completamente alheia, mas parece não saber responder. Maiara diz a ela: "Gabriela, você tem que aprender a falar. Fala o que você quer!" Gabriela permanece em silêncio, meio inquieta. Roberto Ihe estende uma folha A3 e pergunta se é esta folha que quer e ela aceita.

Roberto começa a desenhar imediatamente. Maiara e Josi, sentadas lado a lado, comentam sobre o desenho dele achando graça. Gabriela permanece quieta, pega um lápis grafite e fica segurando-o sem desenhar nada por um longo período. Olha para sua folha, para a toalha da mesa. Os outros três interagem, brincam, riem do desenho um do outro, mas ela fica ensimesmada. Em alguns momentos, dá risada de alguma piada, mas isso acontece raramente.

Então começa a desenhar uma nuvem e um sol bem pequenos no canto superior esquerdo da folha. Para e olha o desenho das outras meninas. Fica assim por um tempo. Então apaga seu desenho e começa a desenhar o que parece uma nuvem razoavelmente maior e mais proporcional ao tamanho da folha.

Maiara e Josi comentam sobre o abrigo onde moravam antes. Interesso-me por saber mais. Contam que Maiara entrou no abrigo em 2007 e Josi já estava lá desde 2006. Maiara desenha uma casa que apaga e faz outra. Preocupa-se em 
desenhar detalhes realistas do abrigo: posição da árvore de natal e papai Noel que enfeita a porta. Josi acha graça da veracidade do desenho e chama a atenção de Roberto, eles riem. Josi comenta que Maiara está fazendo o melhor desenho porque se parece mais com a realidade. Josi comenta que um antigo educador está interessado em adotar um menino que está abrigado lá.

Após 40 minutos, aviso que o tempo se esgotou. Maiara ainda fica terminando seu desenho. Gabriela e Roberto colocam seus desenhos na parede. Josi e Maiara acrescentam falas nos seus desenhos e dão muita risada. Josi escreveu a seguinte frase para finalizar seu desenho: "Não somos totalmente felizes, mas tudo se 'encacha' (sic)". A partir daí, iniciamos a conversa sobre as produções daquele dia.

Pergunto a Josi o que ela quis dizer com a frase que escreveu no seu desenho. Ela diz que o abrigo não é de fato sua casa, por isso não se sente completamente feliz. Não tem a liberdade que teria na sua própria casa. Maiara concorda com a cabeça. Josi conta que desenhou o "tio Rô" e todos riem. Na janela da sua casa, estão desenhados Maiara e o irmão de Josi.

Pergunto se existe algo de bom em morar no abrigo. Josi diz que sim, e aponta em primeiro lugar o convívio com as pessoas. Maiara concorda com ela e diz que, quando voltou para casa, sentiu falta das pessoas do abrigo. Gabriela não responde mesmo estimulada.

Entram no assunto do abrigo anterior novamente. Relatam que lá não havia regras. Todos concordam que a transferência para 0 atual abrigo foi muito complicada. Josi relata que no início, todos os jovens eram muito revoltados, brigavam muito com a equipe do novo abrigo. Roberto lembra dos meninos que já saíram do abrigo, como eles enfrentavam os educadores. Mas conforme estes foram sendo desacolhidos - porque completaram 18 anos - a casa foi se acomodando. Faz apenas um ano que tudo isso aconteceu e a casa parece em harmonia para mim.

Convido que todos olhem os desenhos expostos e, ao ver o de Roberto, Josi pergunta o que ele desenhou. Ele relata que seu desenho representa seu papel no abrigo: encaminhar cada criança ou adolescente para seus caminhos - escola, trabalho, ou o próprio abrigo. Explica que o objetivo de seu trabalho é a família. Fico 
na dúvida se se refere à família externa ou aquela que se constitui no abrigo. Ele diz que é a externa, pois "no abrigo não há família". Chama a atenção os personagens no canto direito do desenho. São todas as crianças e adolescentes que moram no abrigo. Ao todo, estão representados 11 abrigados e o próprio Roberto.

Maiara conta que desenhou o abrigo como ele é, até as falas parecem ser bem realistas. Gabriela ficou por último. Não quis comentar nada do seu desenho. Imediatamente, Josi e Maiara começam a cochichar sobre o desenho de Gabriela, associando a partir dele. Dizem que Gabriela desenhou um foguete que representa seu desejo de ir embora do abrigo de qualquer maneira. Falam que a porta solta no espaço é "a porta da esperança". Mas está fechada. Pergunto para Gabriela o que ela acha, se tem alguma coisa a ver com as intenções dela ao desenhar. Gabriela acha graça do que as meninas estão dizendo e acena positivamente querendo dizer que de fato, o que elas disseram procede com a sua intenção.

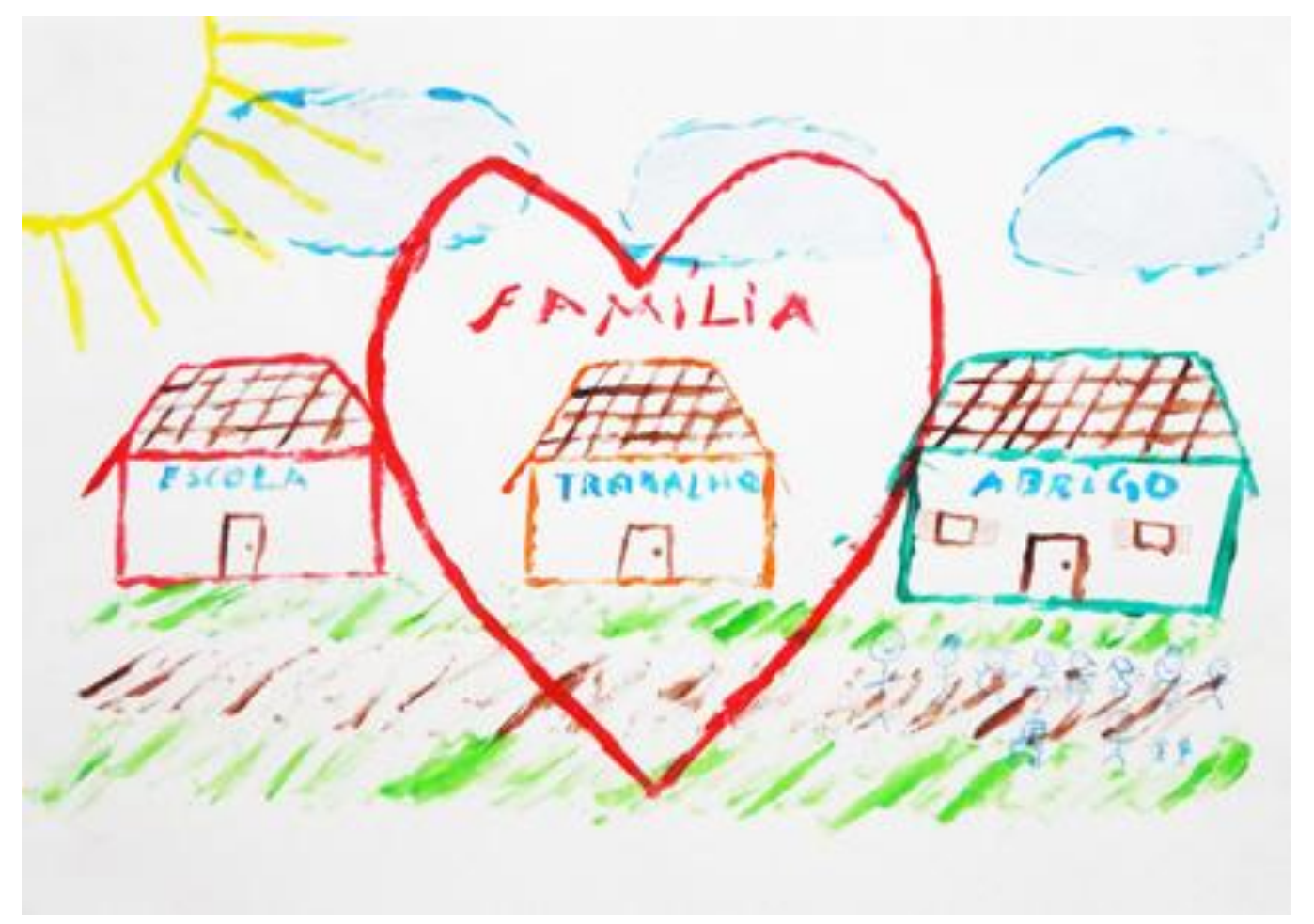

Figura 1- Desenho de Roberto no primeiro encontro. 


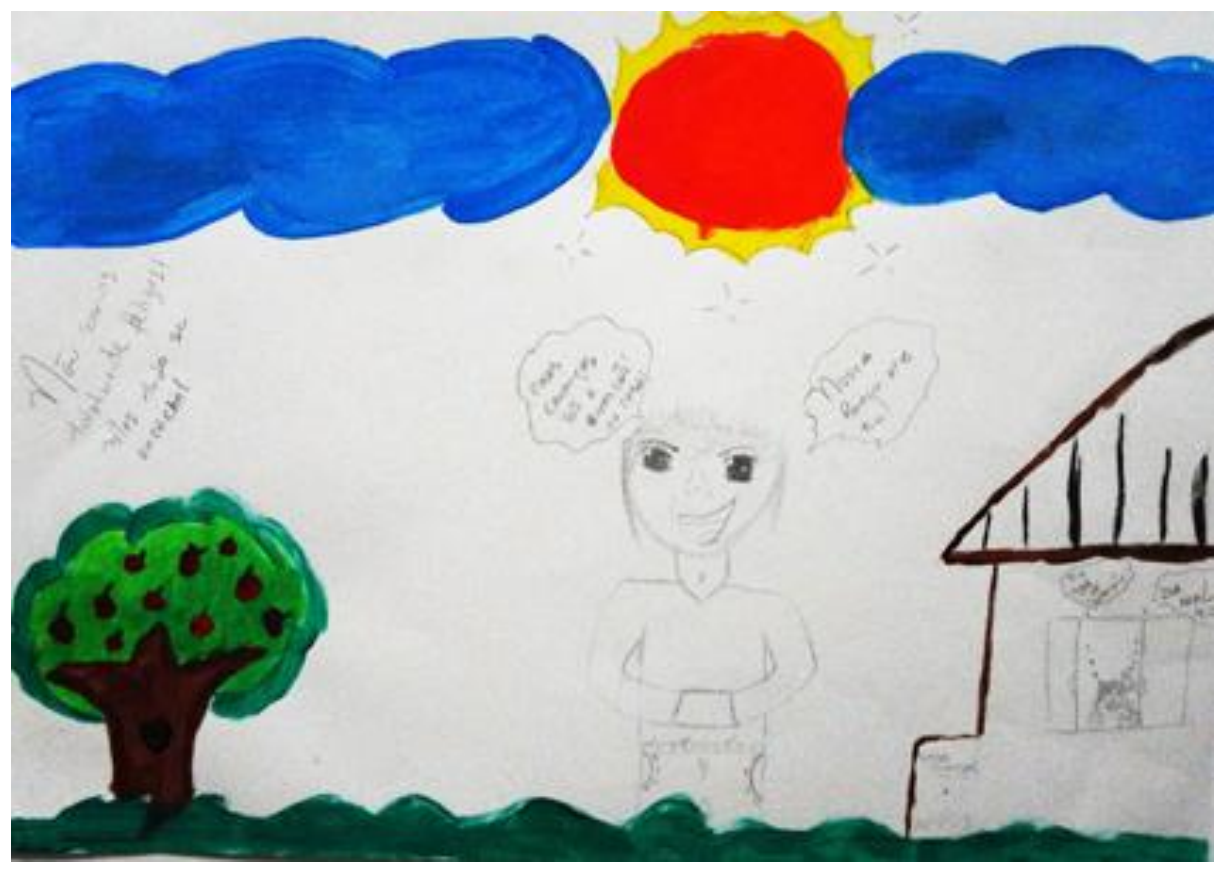

Figura 2- Desenho de Josi no primeiro encontro. Acima da árvore se lê: "Não somos completamente felizes, mas tudo sem 'encacha' (sic)". A figura central é a representação de Roberto que está dizendo: "Essas crianças são a diversão da casa." (esq.) e "Nossa, pareço até tio." (dir.) Na janela estão Maiara e o irmão de Josi. Ela diz: "Tio, liga para a natação". E o menino está pedindo dinheiro: "Dá real, tio".

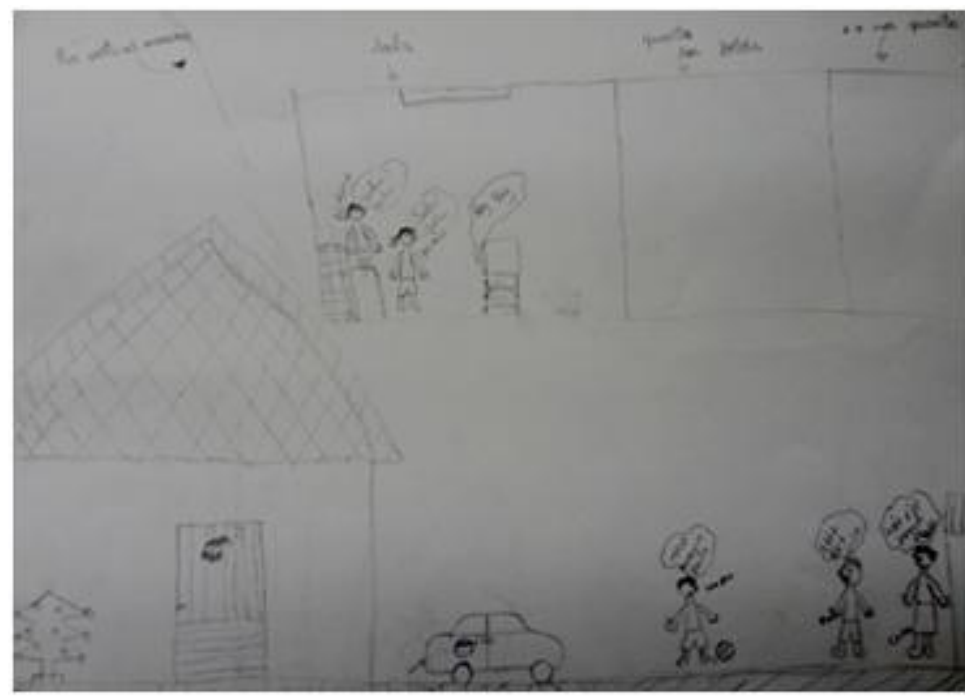

Figura 3- Desenho de Maiara no primeiro encontro.Na parte superior, a ala das meninas está representada por cômodos: sala, quarto dos bebês e quarto. Na sala se vê Josi e Maiara assistindo um cantor americano pela televisão. No canto direito, temos dois meninos do abrigo e uma educadora. A educadora está dizendo: "Não é p/ "brinca' (sic) de bola". Um dos meninos diz: "Cala a boca, Cecília [educadora]" e outro: "Isso mesmo, Kevin. [Kevin é irmão de Josi]" Maiara desenha a fachada do abrigo com os enfeites de Natal na posição onde estavam na realidade e o carro possui o logotipo da prefeitura. 


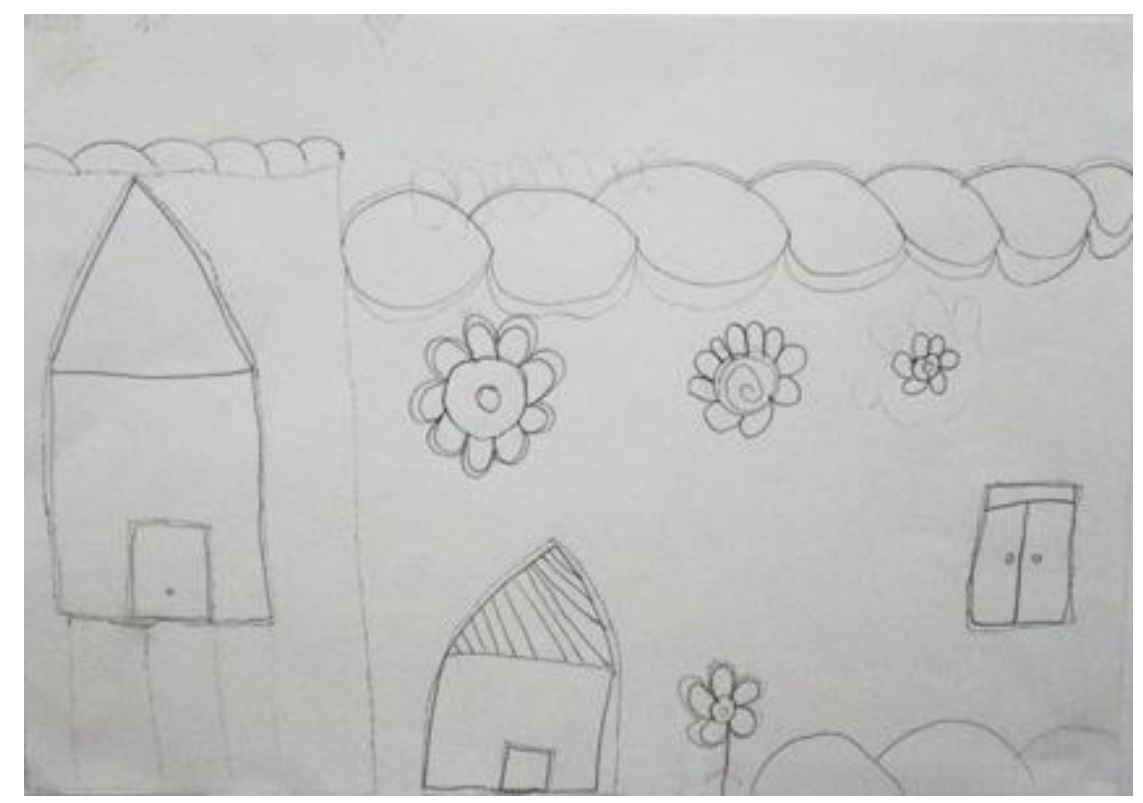

Figura 4 - Desenho de Gabriela no primeiro encontro.

\section{SEGUNDO ENCONTRO}

"O que há atrás da 'porta da esperança'?"

Quando chego, Maiara e Gabriela estão no refeitório com uma educadora. Gabriela faz algumas tarefas e Maiara observa. Josi estava dormindo e Roberto vai acordá-la. Quando todos estão presentes, faço a proposta do desenho de tema livre. Eles estranham um pouco o fato da proposta não ser dirigida como no primeiro encontro, mas Roberto toma logo a dianteira, pega uma folha e distribui para as meninas. Josi vai até seu quarto e busca uma pasta onde guarda desenhos feitos por ela. Escolhe uma rosa para copiar. Todos começam a trabalhar, menos Gabriela que fica muito tempo olhando a folha em branco, por vezes presta atenção no que as outras meninas estão conversando. Sento ao lado dela e tento estimular dizendo que pode desenhar o que quiser, mas não surte efeito. Surge uma conversa sobre preferências pessoais (cor, comida etc.). Todos se divertem dizendo suas escolhas, mas Gabriela sempre diz não saber qual sua cor preferida por exemplo. 
Então mostro a ela que temos outras cores de papel além daquela escolhida por Roberto. Ela aceita minha sugestão e pede uma folha azul, menor do que a anterior. Mesmo assim, fica em dúvida sobre o que desenhar. Pergunto do que ela gosta. Josi interfere e pergunta: "Você não gosta de flores? Porque desenhou na semana passada... Então, desenha flores..." A princípio, Gabriela acata, mas depois apaga.

Peço para ver os desenhos de Josi que estão na pasta. Muitos são imagens estereotipadas e de bandas que gosta. Tanto ela quanto Maiara parecem mais soltas e à vontade comigo. De repente, elas revelam que Maiara está na escola há mais de um ano e não tem amigos. Josi diz que não pode ser assim, que Maiara tem que se entrosar e num tom queixoso reclama que Gabriela não se entrosa com elas. Segundo Josi, ela e Maiara fazem todo o possível, mas Gabriela permanece alheia. Gabriela ouve, mas não diz nada. Novamente se mostra inquieta, como na primeira oficina, como se quisesse falar, mas não conseguisse; como se quisesse desenhar, mas também não conseguisse.

Voltam ao assunto do abrigo anterior. Maiara e Josi dizem que preferem o abrigo antigo ao passo que Roberto,entre brincadeiras, questiona se lá era mesmo um bom lugar. As meninas dizem que o abrigo atual é de fato mais organizado e tranquilo, porém, não têm liberdade, não vão a festas, passeios e não tem padrinhos. Gabriela acompanha estas conversas sempre à parte.

Quando acontece alguma piada, dá risada. Sento-me novamente ao seu lado e digo que, às vezes não conseguimos fazer alguma coisa porque temos muitas outras passando pela nossa cabeça. Ela confirma com a cabeça. Digo que, na dúvida, podemos escolher apenas uma. Então ela começa a desenhar e após um tempo, quando volto a ver, dou-me conta que ela desenhou o mesmo desenho da semana passada, mas desta vez, o fez colorido e à tinta.

Desde o início da oficina, fazia muito calor e observei que Gabriela estava de casaco todo fechado. Parecia estar com calor pelas bochechas afogueadas. Pergunto se não gostaria de tirar o casaco, mas ela se recusa. Penso na suspeita de gravidez e se ela estaria escondendo a barriga. Uma educadora surge e também fala para ela tirar o casaco, mas ela não acata. 
Todos colocaram seus desenhos na parede e sentamos num semicírculo. Gabriela não quer falar nada sobre seu desenho e as outras meninas tentam estimulá-la, mas Gabriela faz cara de enfado. As duas amigas pressionam Gabriela para que ela explique porque não se entrosa com elas. Gabriela novamente parece não saber o que falar. Maiara e Josi retomam o assunto da transferência do abrigo antigo e procuro saber delas como foi a adaptação a este novo abrigo, o que sentiram quando foram abrigadas pela primeira vez. Maiara conta que sentiu medo. Josi fica quieta. Tento aproximar a experiência delas e o comportamento retraído de Gabriela, sugerindo que esta precisa de um tempo para se adaptar às novas circunstâncias.

Esta oficina parece dar continuidade ao que iniciamos na semana anterior: Roberto desenhou-se cercado por crianças, mas desta vez eram seus sobrinhos. Diz que, durante a semana trabalha no abrigo e aos finais de semana cuida dos oito sobrinhos. Não tem filhos, mas dedica-se muito às crianças do abrigo e aos sobrinhos. Conta que não tem sossego em relação ao abrigo. Mesmo nas suas folgas, liga para o abrigo com o intuito de saber se está tudo bem. Diz que considera os meninos do abrigo como se fossem seus filhos e percebo que todas ficam muito atentas quando ele fala da sua família.

Maiara e Josi parecem desenvolver a ideia da esperança começada na semana anterior através da projeção sobre o desenho da "porta da esperança": a primeira desenha um sol nascendo e a segunda, uma rosa de cores inusitadas. Já Gabriela, persistiu no mesmo desenho, mas desenvolveu-o num papel azul e tinta. As cores parecem ter sido incorporadas por todos, o que não ocorrera na semana anterior. Novamente a "porta/janela" de Gabriela parece intrigar a todos. Comento o quanto aquela porta parece misteriosa. O que haveria atrás dela? Percebo também a iniciativa de colocar os respectivos nomes na frente dos desenhos. 


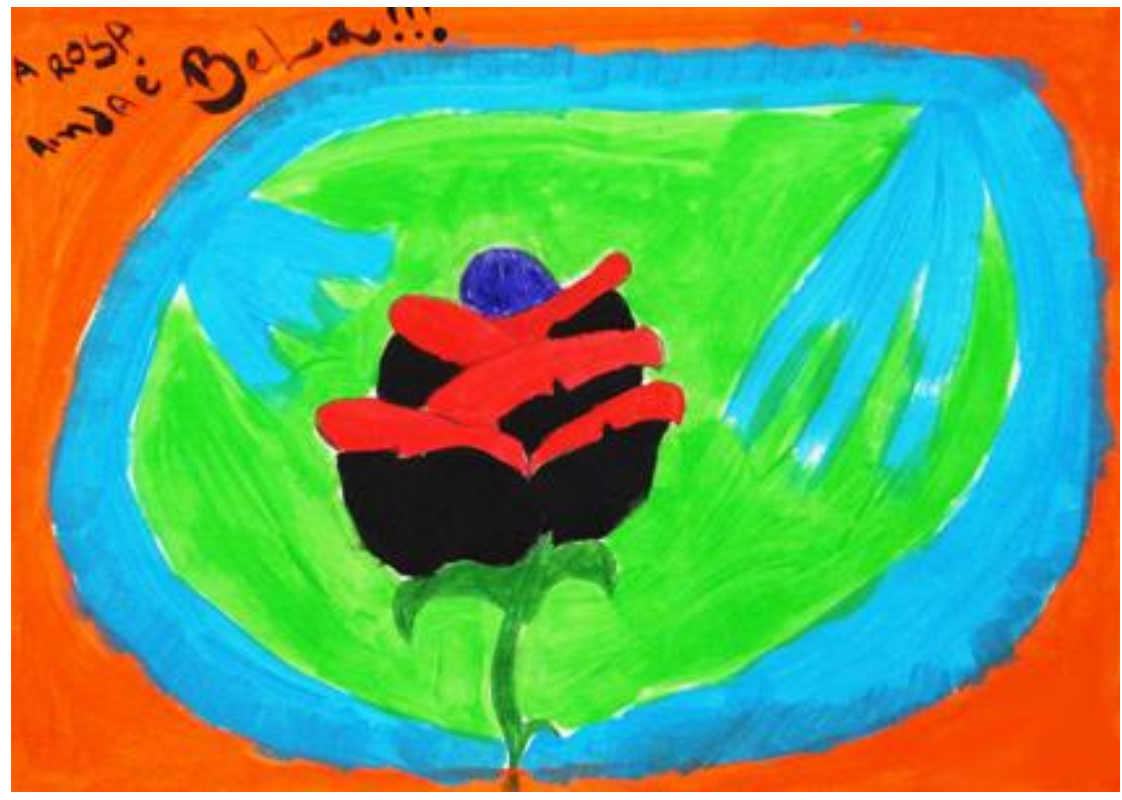

Figura 5 - Desenho de Josi no segundo encontro. Está escrito: "A rosa ainda é bela".

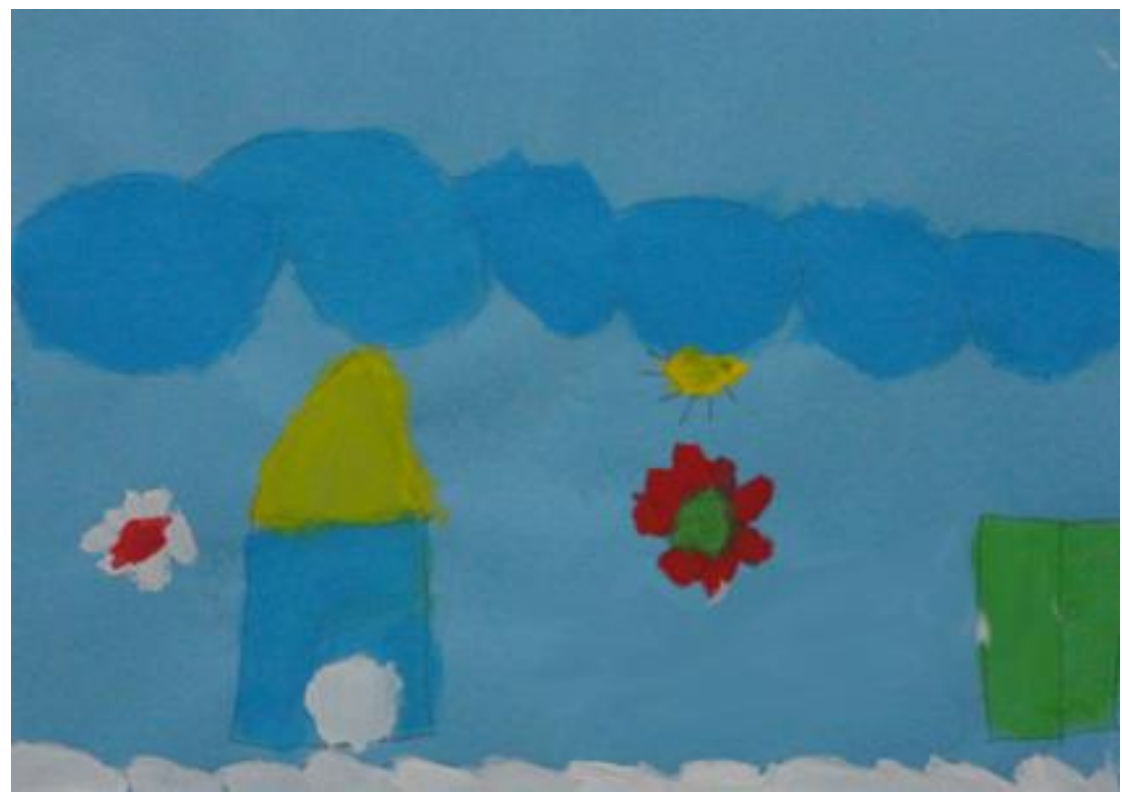

Figura 6 - Desenho de Gabriela no segundo encontro. 


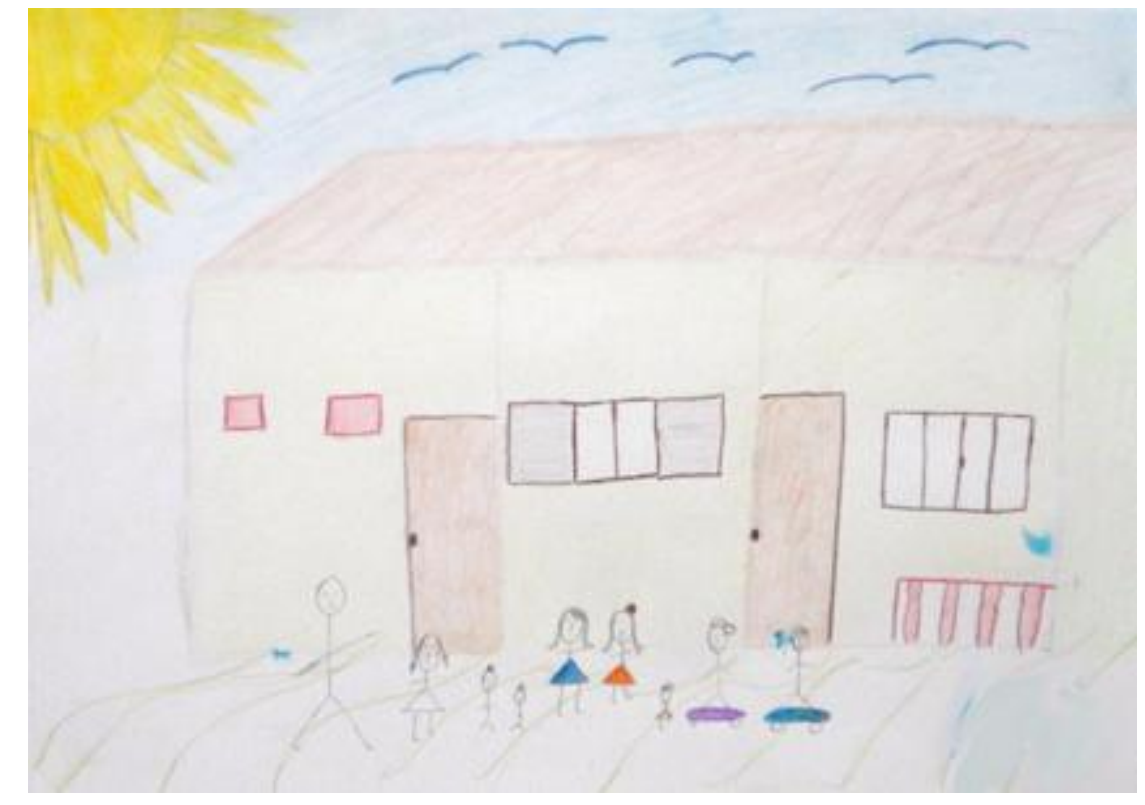

Figura 7 - Desenho de Roberto no segundo encontro.

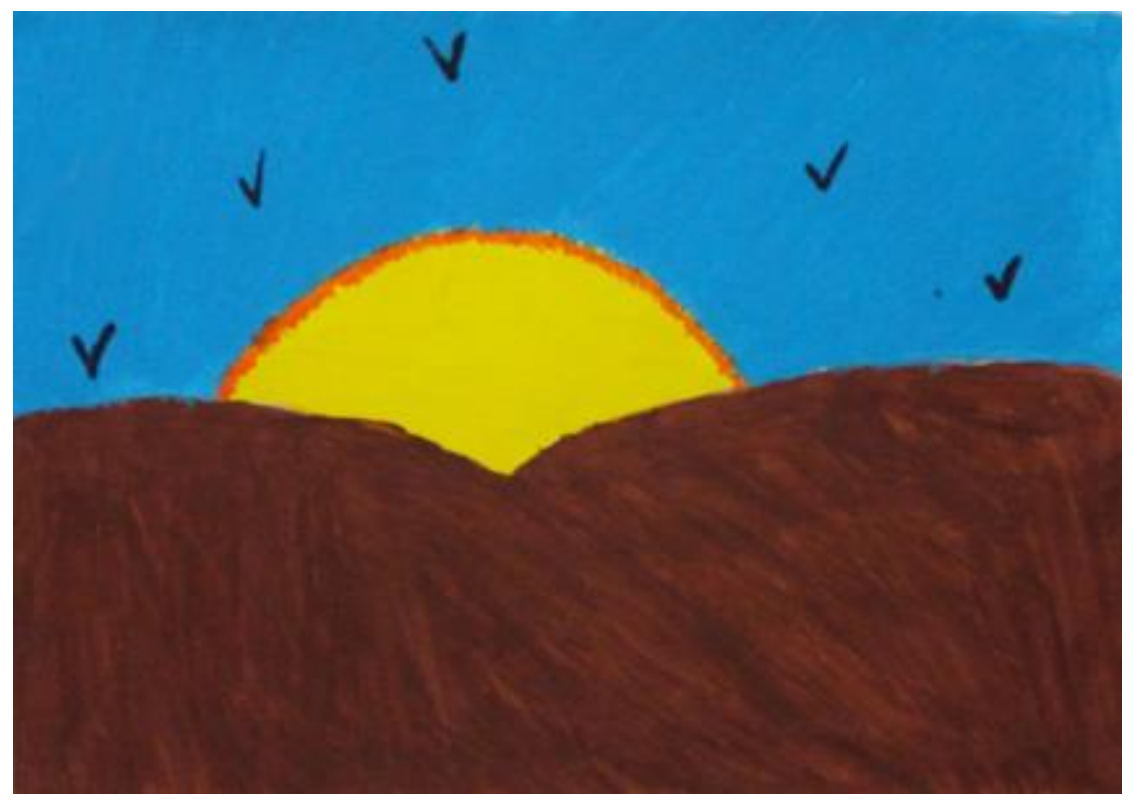

Figura 8 - Desenho de Maiara no segundo encontro. 


\title{
TERCEIRO ENCONTRO
}

\author{
“O Natal 'pobre' no abrigo"
}

Quando estou chegando, encontro Roberto e Gabriela saindo para buscar remédio para a menina. Como eles não voltaram até a hora de início da oficina, inicio com Josi e Maiara. Enquanto preparo os materiais, as meninas conversam com a psicóloga do abrigo sobre algumas caixinhas de découpage que estão fazendo. Dizem que querem vender e a conversa se dá em torno do que será feito com o dinheiro que receberem e o que gostariam de ganhar de Natal. Josi diz que vai ligar para a mãe e pedir seus presentes e comenta: "Já que ela não vem me ver, tem que me dar presente!". Já Maiara, insiste com a psicóloga do abrigo para poder passar as festas com o irmão que já havia pedido permissão.

Esta oficina é a primeira desde que entraram de férias e reclamam muito por não poderem sair do abrigo para passear, encontrar amigos ou qualquer outra finalidade de lazer ${ }^{25}$.

Maiara desenha uma árvore de Natal e pergunto o que ela pensa desta data. Ela responde que se trata de um dia especial para encontrar pessoas que gosta, por exemplo, a família. Josi fala que é uma data como outra qualquer, principalmente no abrigo, onde não se faz nada de diferente. Então, olhando para a árvore de Natal desenhada por Maiara, comenta que ela está tão pobre quanto o Natal do abrigo. Explicam que lá, o Natal é comemorado antes do dia oficial e no próprio dia não há nada de especial: nem ceia e nem podem ficar acordados até mais tarde. Sobre seu desenho, Josi diz que está voando para alcançar o céu, mas não está um dia bom, pois está chovendo e "chuva não é bom". Mas observando seu desenho, continua dizendo que nele há mais do que o lado ruim representado pela chuva, existe algo bom simbolizado pelo Sol.

Enquanto as meninas desenhavam, Roberto chegou um pouco incomodado. Disse que foi buscar o remédio com Gabriela e quase chegando ao abrigo, a menina pediu para voltar ao posto médico, pois estava com dores de cabeça. Ele a deixou lá

\footnotetext{
${ }^{25}$ Essa "proibição" de saírem será desmentida na devolutiva com a coordenadora do abrigo, que se encontra na sequência deste trabalho.
} 
com outra educadora e voltou ao abrigo. Para ele, não passavam de desculpas para sair do abrigo. Tento conversar sobre o porquê de Gabriela querer sair de lá e o próprio Roberto relata que ela se queixa muito de saudades da mãe. Mal ele havia sentado e começado a desenhar, toca seu celular: era a educadora que acompanhava Gabriela pedindo que ele fosse buscá-las, pois a menina passou em consulta médica e não tinha problema de saúde nenhum. Ele sai contrafeito. Voltam certo tempo depois e Gabriela nos ouve comentando sobre os desenhos, sorri e vai direto para o seu quarto. Roberto conta que ela não aguenta mais ficar ali no abrigo. Coloco-me a disposição para conversar com ela após a oficina, caso ela queria.

Quando Roberto volta, Josi faz questão de mostrar os desenhos dela e de Maiara. Percebo que é um momento delicado no qual ela gostaria que ele se inteirasse sobre o que foi conversado. Tento estimular para que as meninas contem, mas elas se acanham. Pergunto se posso contar e devidamente autorizada conversamos sobre a "pobreza" do Natal no abrigo. Como a oficina se dá no refeitório e este se situa num local de passagem, é comum que outras pessoas passem enquanto a oficina acontece e algumas até se detém por algum tempo. No momento em que Roberto ouvia sobre as queixas das meninas, outra educadora ouvia tudo - Paula. Os dois educadores presentes resolvem fazer, naquele ano, um Natal diferente.

Finalizada a oficina, Roberto diz que Gabriela está me esperando no quarto para conversar. Muito diferente de como se mostrou nas duas primeiras oficinas, Gabriela está muito falante contando o quanto está "agoniada" de saudades. Diz que, desde que foi abrigada (há aproximadamente 4 meses) não viu os pais e diz que são muito "apegados". Quer ir embora de qualquer forma para vê-los e cogita até a possibilidade de fugir. Não compreende porque algumas crianças e adolescentes da casa podem ter contato com a família e ela não; assim como também diz não entender o motivo que a levou até ali. Percebo que se trata de uma dificuldade de significar o que aconteceu fora do abrigo e que culminou na sua institucionalização. Tento estimular, pergunto por que ela acha que está abrigada? Explico que crianças são abrigadas quando acontece algo em casa que o juiz considera que não seja bom para elas. Mas independente dos meus esforços, ela se mantém firme dizendo que não entende o motivo de estar ali e de não poder ver o 
pai. Sugiro que converse com a psicóloga do abrigo e pergunte a ela estas questões. Conta que se sente muito mal ali no abrigo, principalmente por não poder sair, passear. Não se sente à vontade nem com as outras meninas, nem com Roberto. Ao final, tenta encontrar a psicóloga do abrigo para conversar, mas ela não se encontra mais ali.

No refeitório, Paula está na companhia de Josi e Maiara e, com vários papéis coloridos, estimula as meninas para que usem o material e criem uma decoração de Natal para o espaço e diz: "Vamos, meninas, vocês não queriam um Natal diferente? Então vamos começar mudando este espaço". Sugiro que Gabriela se integre ao grupo, mas instantaneamente a menina volta a ficar retraída e um tanto desconcertada. Este comportamento irrita Josi que se mostra impaciente. Maiara se mostra mais compreensiva tentando se colocar no lugar de Gabriela e pedindo que Josi não pegue no pé dela. Josi não dá ouvidos e é muito dura com Gabriela. Paula pede que Gabriela vá buscar uma tesoura no quarto das meninas, mas certo tempo se passa e ela não volta, me dando a sensação que não voltará mais para ajudar.

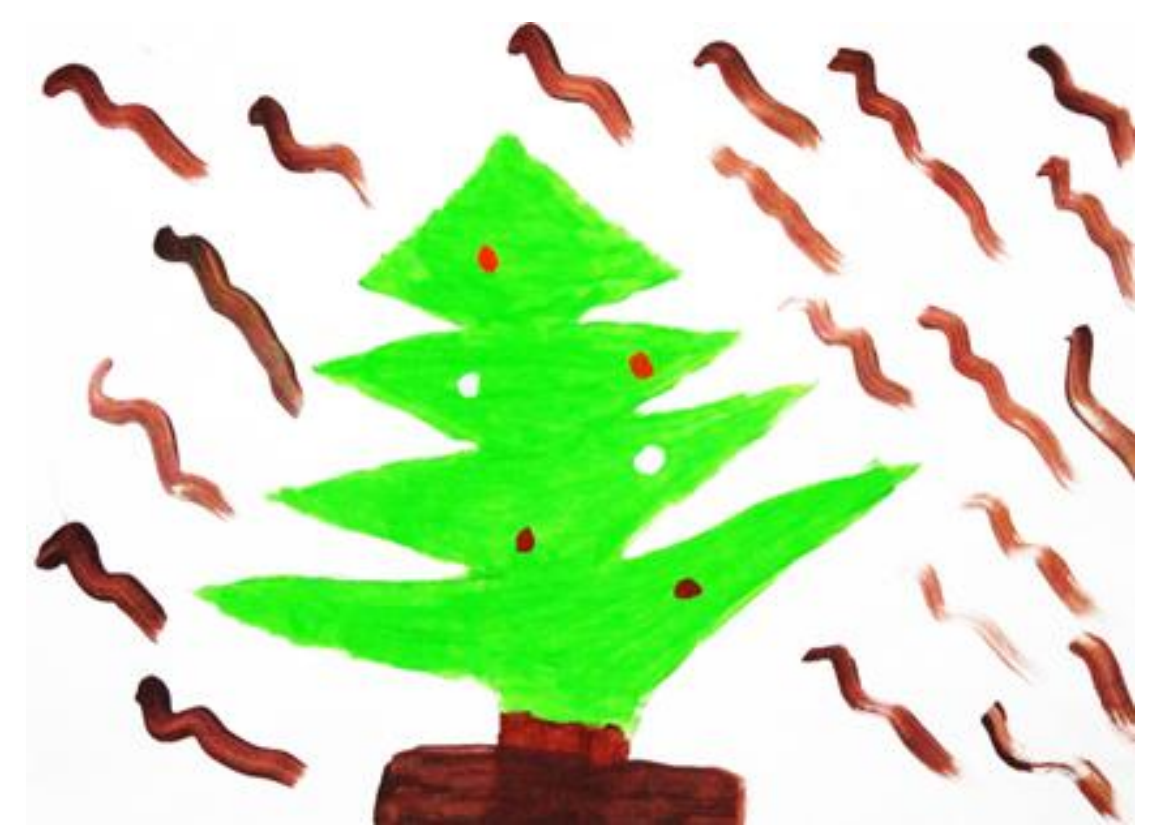

Figura 9 - Desenho de Maiara no terceiro encontro. 


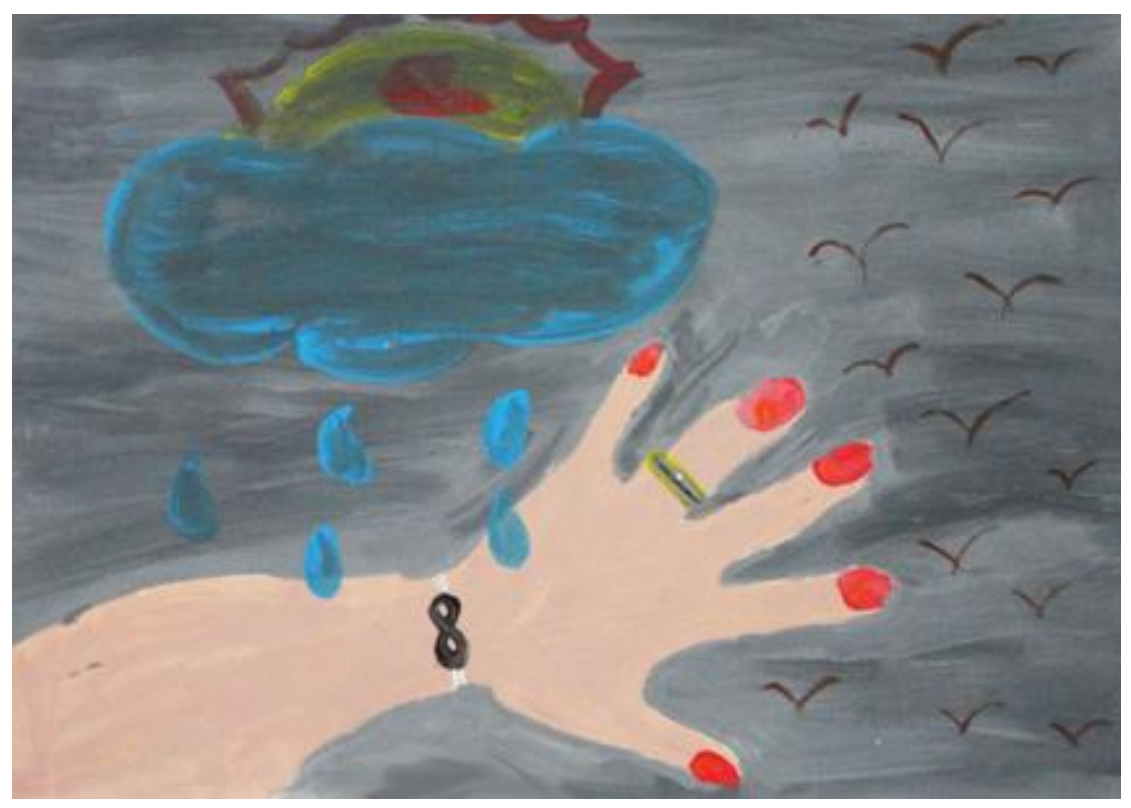

Figura 10 - Desenho de Josi no terceiro encontro.

\section{QUARTO ENCONTRO}

"Por que o coração sofre tanto?"

Chego à mesma hora e logo na porta de entrada, Meire, uma educadora, me informa que aquele dia é feriado na cidade e que Josi não vai querer participar. Roberto não havia ido trabalhar e nem teria acesso aos meus materiais guardados numa sala cuja chave estava na administração que se encontrava trancada.

Resolvi conversar com as meninas e Josi - que estava no sofá assistindo televisão - se prontifica rapidamente a tentar arranjar algumas folhas de papel sulfite para que realizemos a oficina. Participam as três meninas e Guilherme, um menino de 11 anos. Josi e Maiara trazem seus estojos da escola e emprestam a todos os lápis. Guilherme ocupou muito o espaço da oficina: falando, cantando músicas em inglês e contando a sua história de maneira sucinta: é de uma cidade do interior de São Paulo, veio morar com a mãe, mas esta não pôde cuidar dele. Josi e Maiara trocam olhares o tempo todo e ficam quietas, demonstrando o descontentamento 
com a presença de Guilherme. O menino faz algumas brincadeiras de mau gosto e caçoa das meninas. Sou obrigada a afirmar as regras de respeito mútuo que existe no grupo. Percebo que ele tenta se controlar daí em diante, mas ainda escapam alguns comentários.

Gabriela mostra dificuldades para desenhar novamente, mas, com a presença de Guilherme, as atenções não estão mais voltadas para ela. Josi desenha um coração que escorre gotas de sangue. Digo que parece um coração que sofre e pergunto por que será que ele sofre tanto? Guilherme responde, dizendo que sofre, pois a mãe o machucou, encravando um osso na testa da caveira, pois Josi fez bagunça. Possivelmente, ele projetou no desenho de Josi seus próprios sofrimentos. Neste dia, ninguém quis comentar os desenhos, menos o menino que falou de sua produção de forma descritiva.

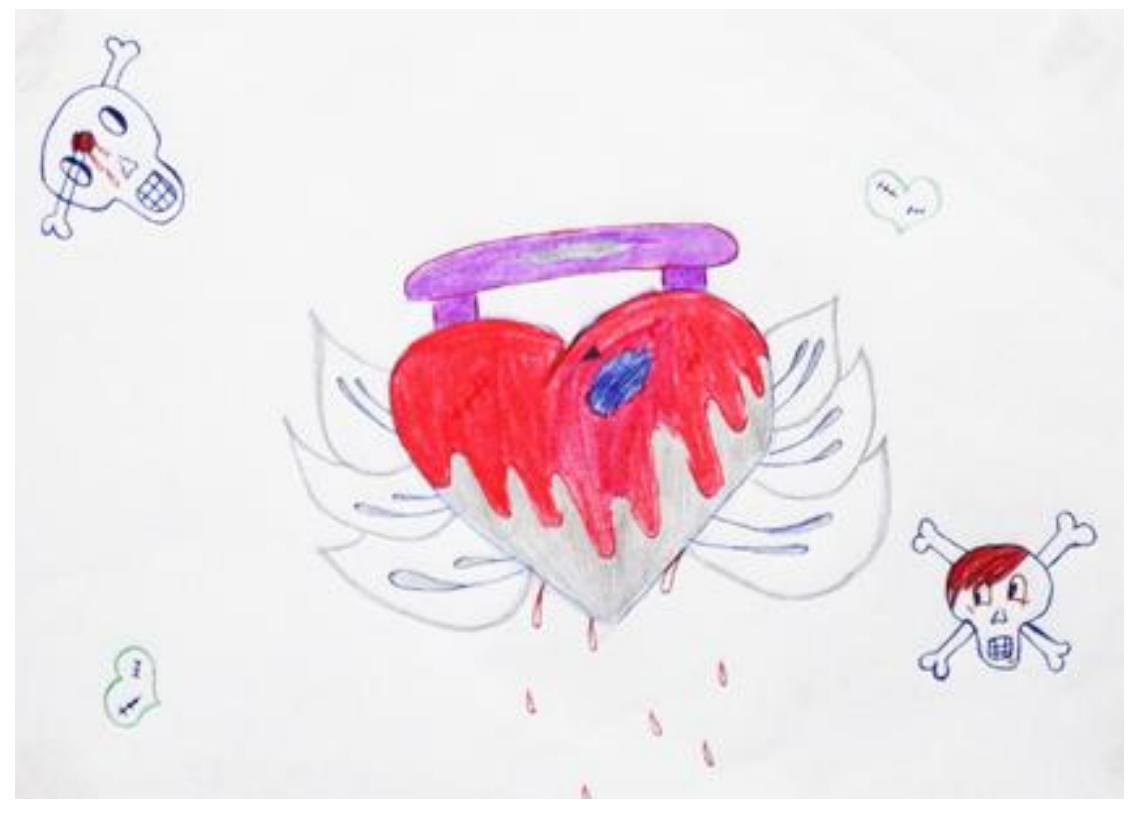

Figura 11 - Desenho de Josi no quarto encontro. 


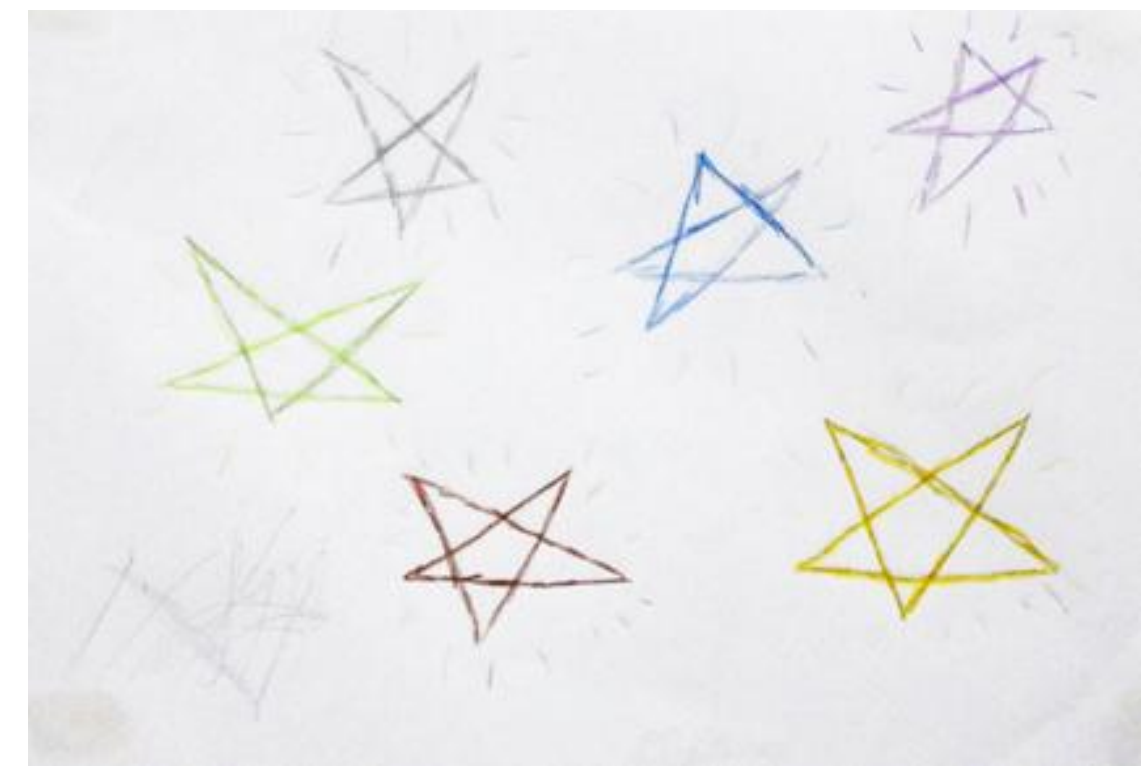

Figura 12 - Desenho de Maiara no quarto encontro.

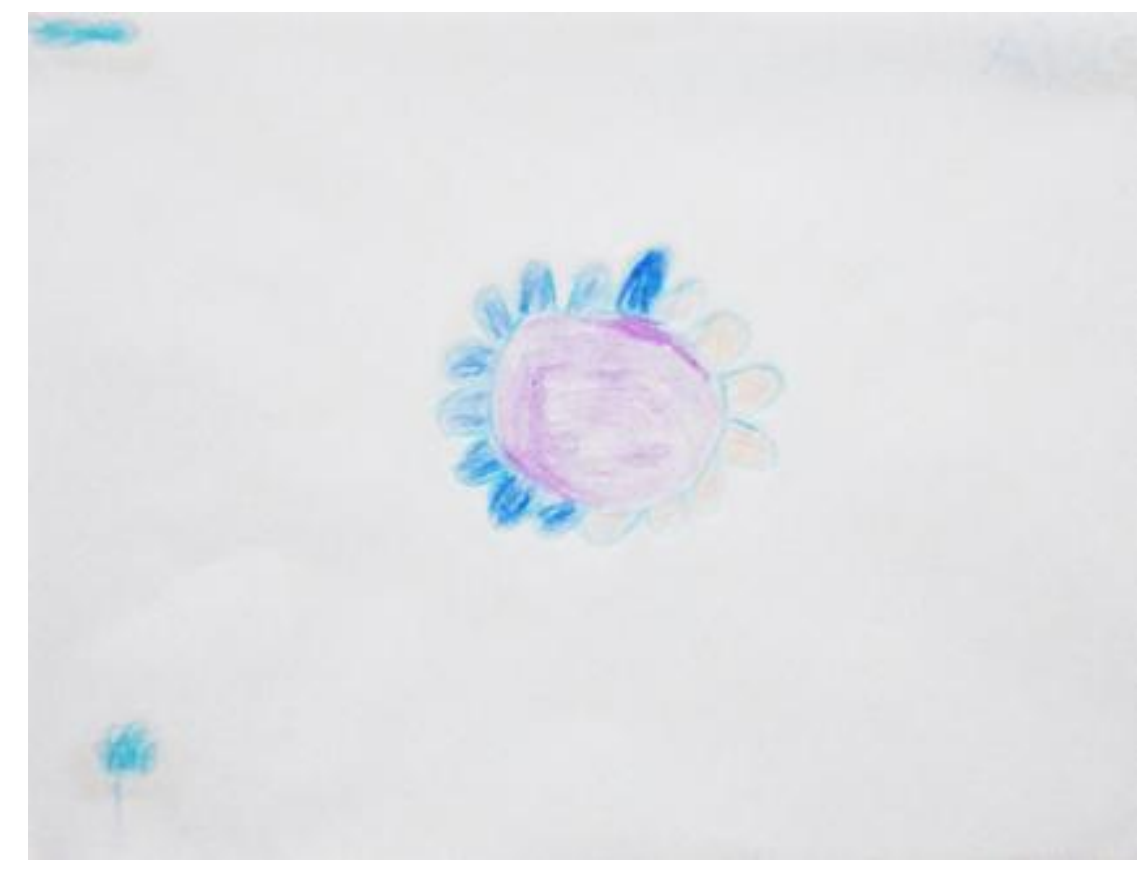

Figura 13 - Desenho de Gabriela no quarto encontro. 


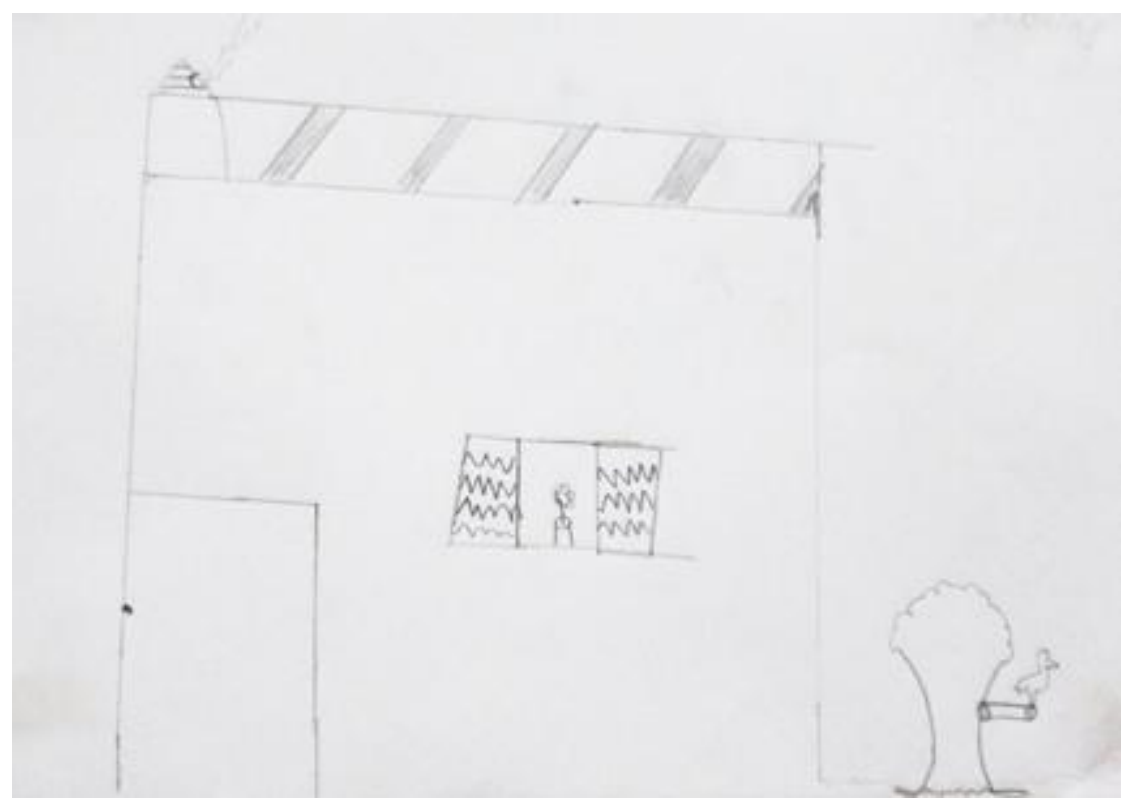

Figura 14 - Desenho 1 de Guilherme no quarto encontro.

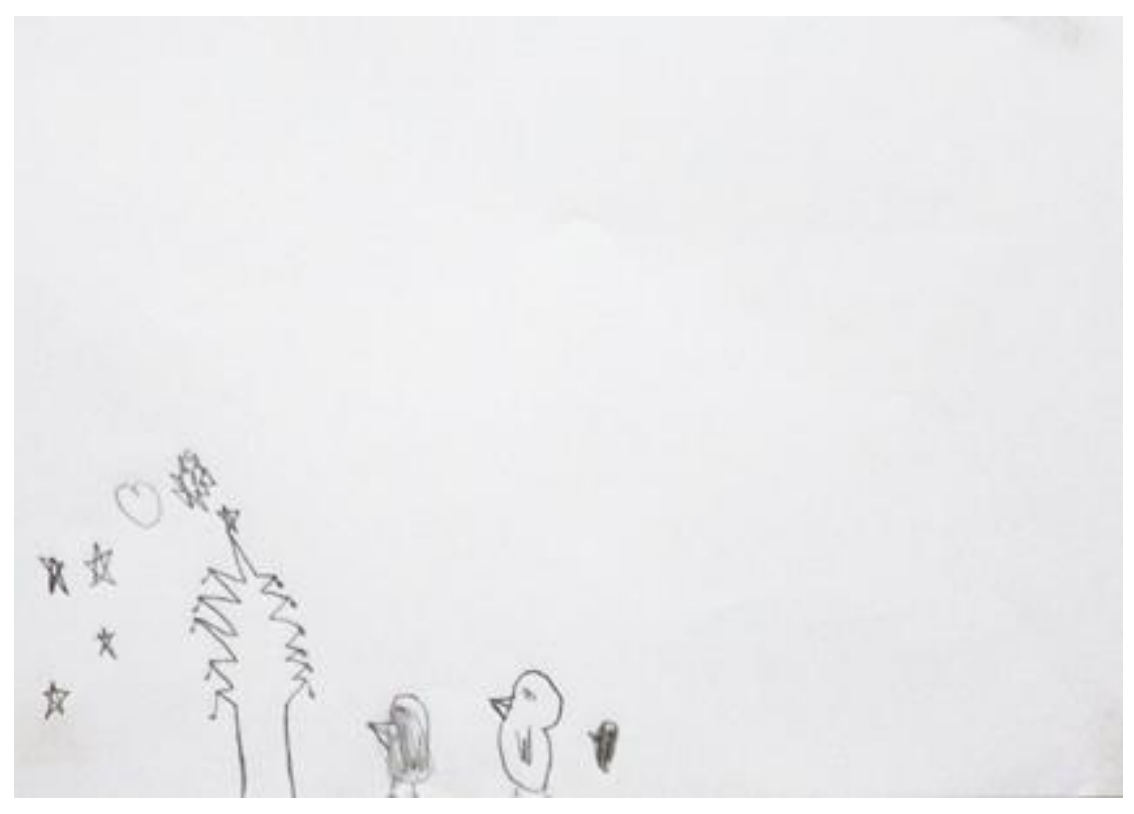

Figura 15 - Desenho 2 de Guilherme no quarto encontro. 


\section{QUINTO ENCONTRO}

“Ô Josi, você não vai fazer, não?”

Neste dia, dividi a mesa que sempre utilizei com a psicóloga do abrigo que fazia caixinhas de découpage. Este fato, associado à aproximação do Natal e da sua comemoração que seria no dia seguinte, dispersaram muito os participantes da oficina. Maiara, Guilherme e Roberto foram os primeiros a se aproximar. Josi e Gabriela chegaram com algum atraso, pois haviam ido ao salão de beleza em função da festa que ocorreria no dia imediato.

Quando chega, Josi se senta na ponta oposta da mesa, onde se faziam as caixinhas de découpage. Maiara está muito calada e quem domina a oficina é Guilherme que fala muito. Pergunta à psicóloga do abrigo como se escreve "eu amo vocês" em japonês (ela é descendente de japoneses). Maiara termina seu desenho rapidamente e se junta a Josi. Logo que chegou, Gabriela se senta e começa a desenhar, sem qualquer hesitação como antes. Comento que está usando cores naquele dia e a menina sorri. Josi conta que Gabriela paquerou um menino na rua e esta última da risada e interage.

Num determinado momento, Roberto chama Josi e pergunta: "Ô Josi, você não vai fazer, não? [desenho]". Então ela se levanta e diz: "Vou, eu prometi que ia participar e vou fazer rapidinho." Ressalto que a participação não é obrigatória, mas ela insiste. Como disse, fez seu desenho rapidamente e volta a se sentar do outro lado da mesa.

Vendo a estrutura da oficina desmontada, sugiro a discussão dos desenhos, mas ninguém quer participar. Então finalizo o trabalho dizendo o quanto todos parecem muito ansiosos para a festa.

Quando estou de saída, converso rapidamente com a diretora do abrigo que conta ter pedido a autorização da juíza para que Gabriela recebesse a visita da mãe no Natal para aplacar a ansiedade da menina. 


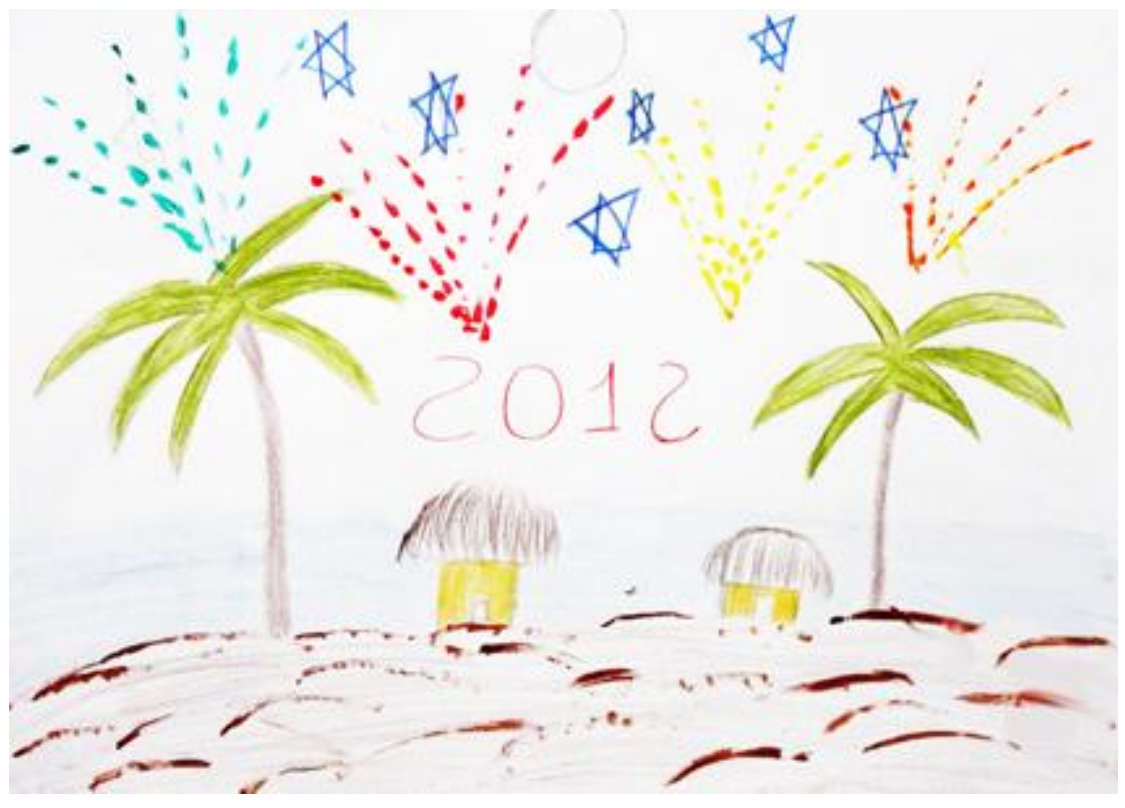

Figura 16 - Desenho de Roberto no quinto encontro.

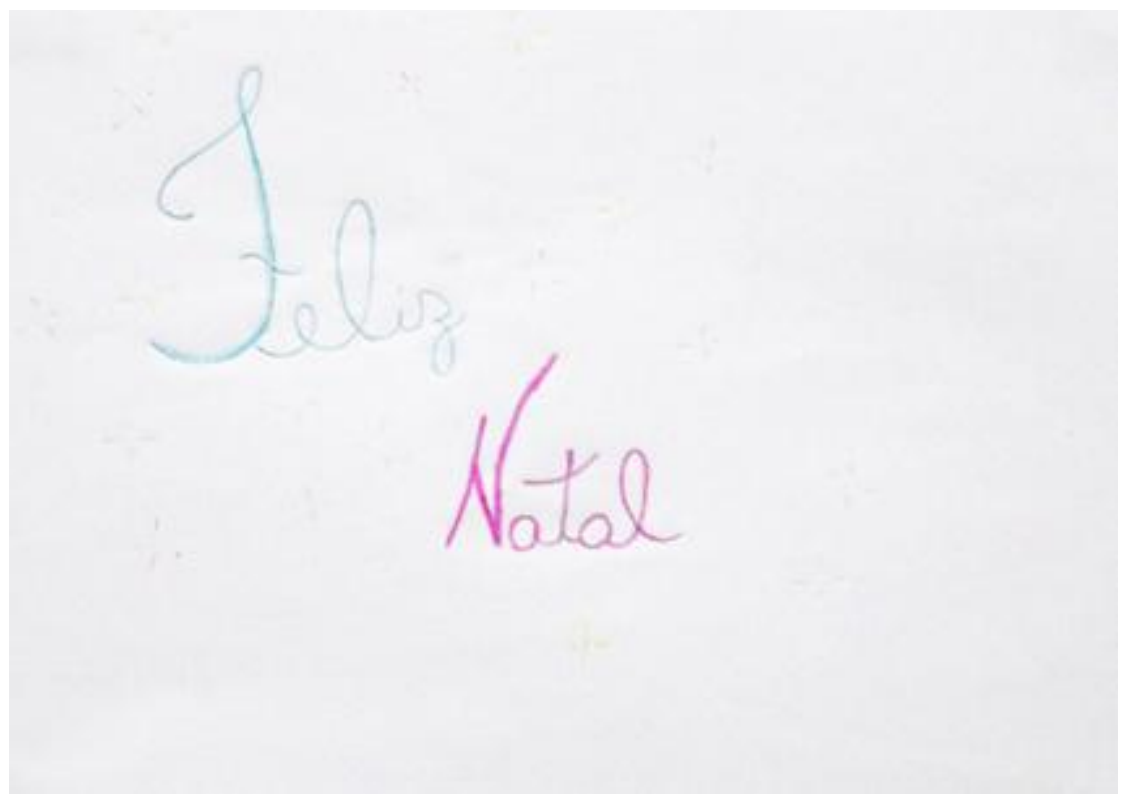

Figura 17 - Desenho de Maiara no quinto encontro. 


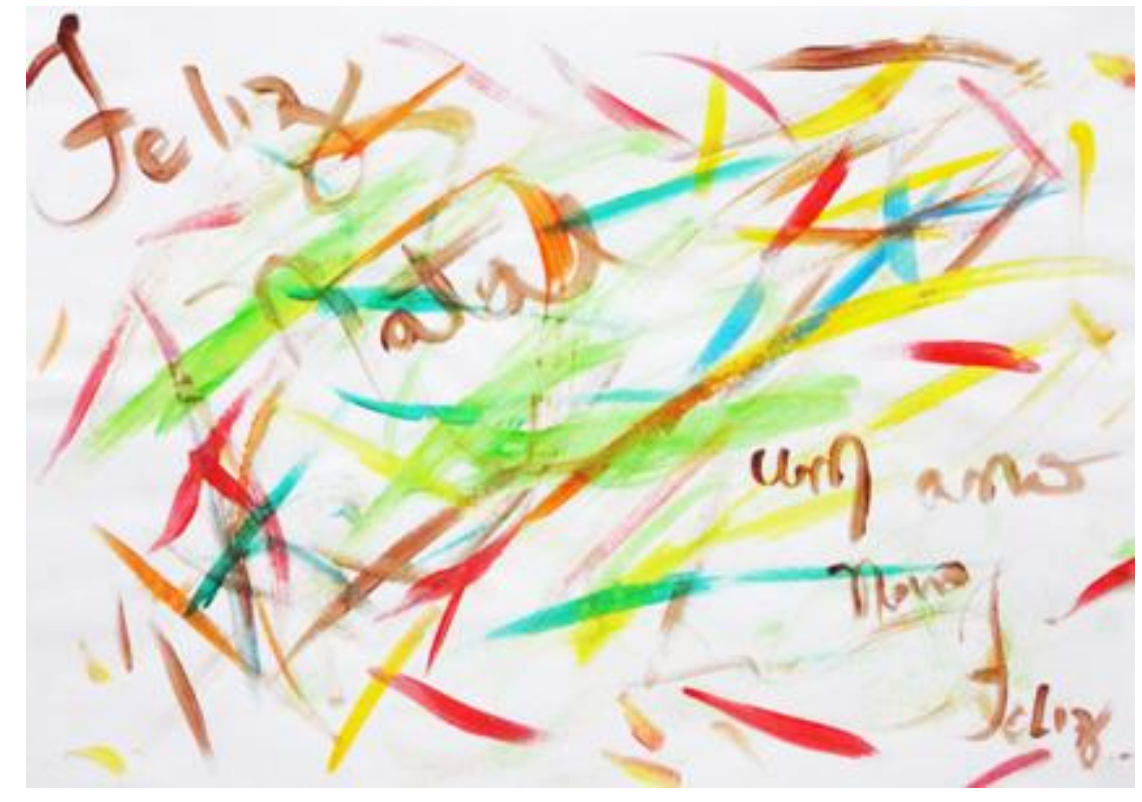

Figura 18 - Desenho de Josi no quinto encontro.

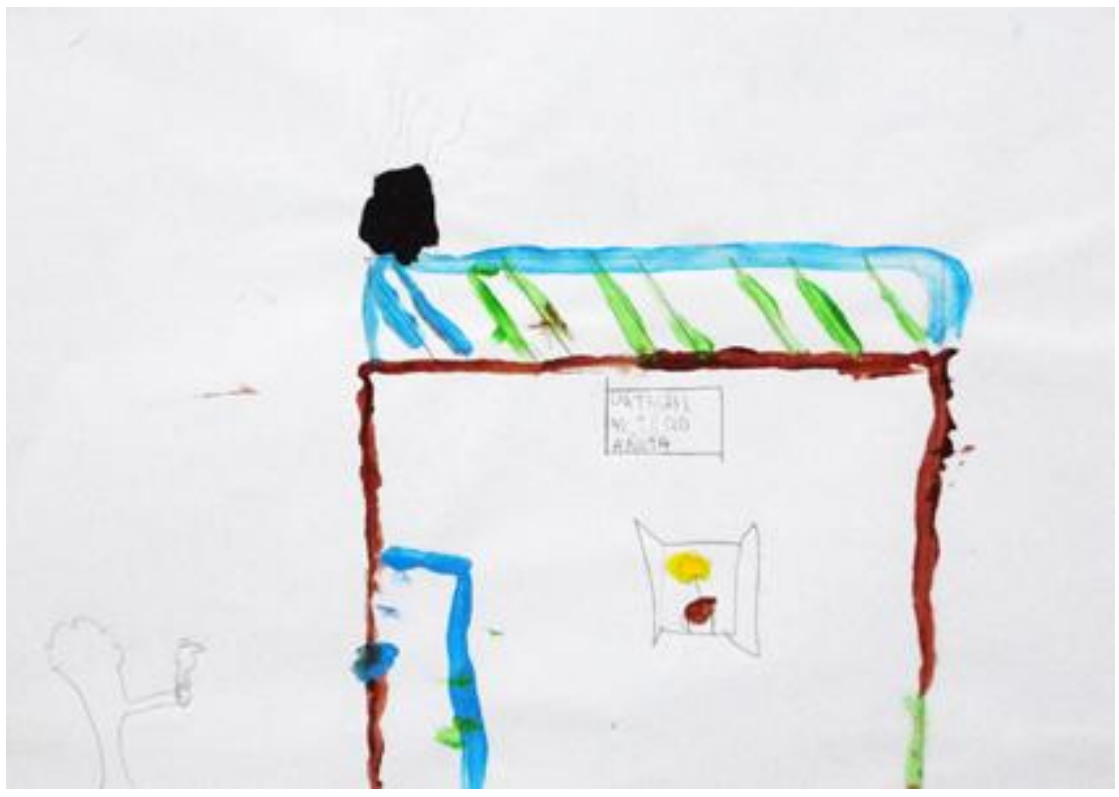

Figura 19 - Desenho 1 de Guilherme no quinto encontro. Acima da janela está escrito "eu amo vocês" em japonês. 


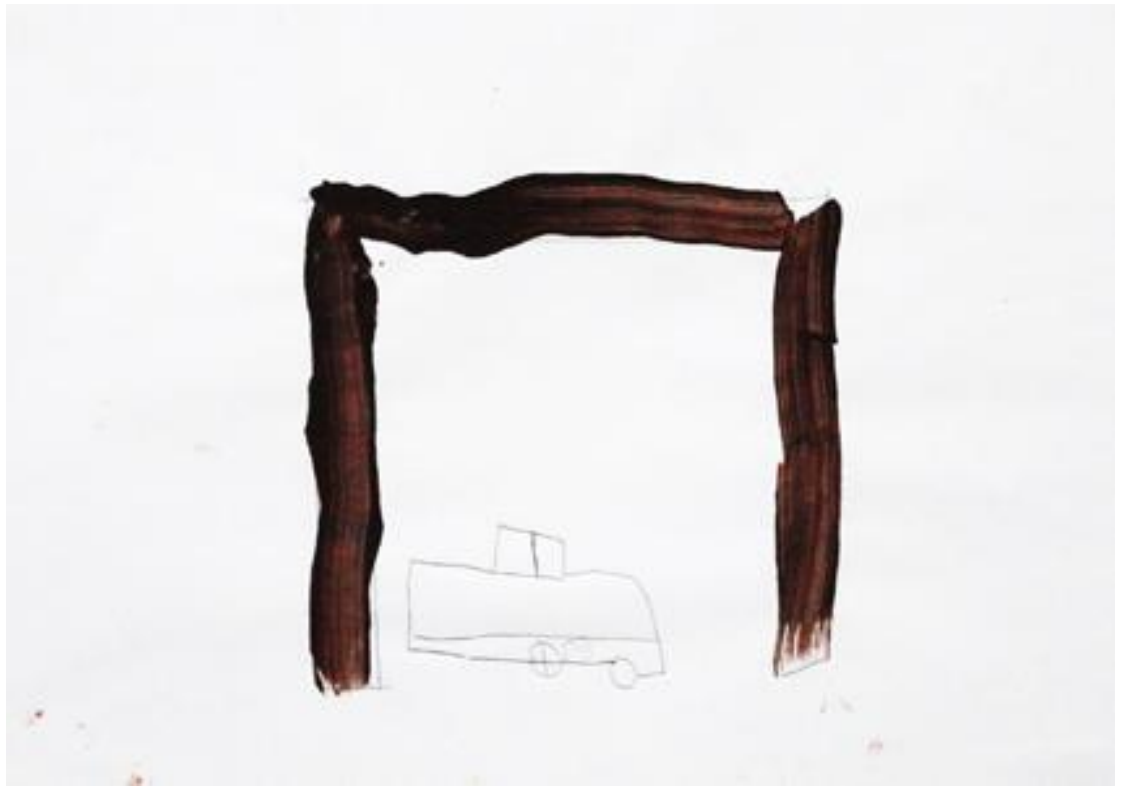

Figura 20 - Desenho 2 de Guilherme no quinto encontro.

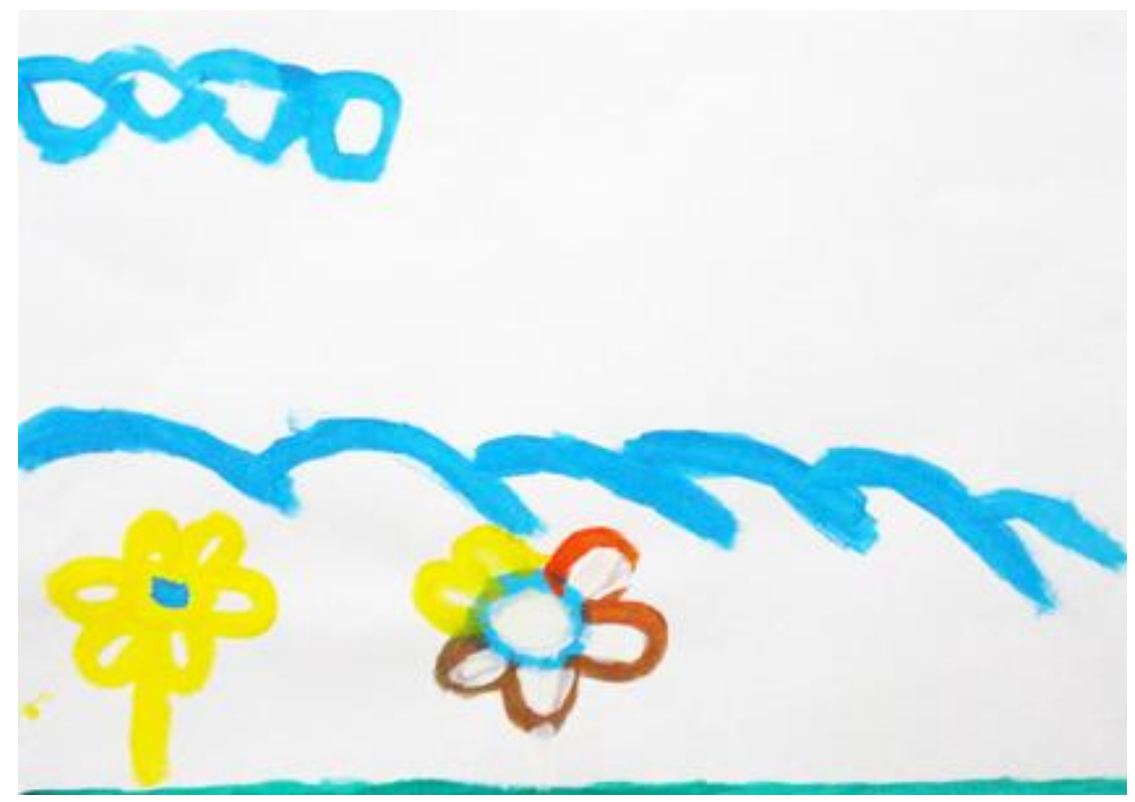

Figura 21 - Desenho de Gabriela no quinto encontro. 


\title{
SEXTO ENCONTRO
}

\author{
"A casa invisível"
}

Ocorre com um intervalo de quinze dias da última, pois, entre a semana do Natal e Ano Novo, tanto Josi como Maiara estão fora do abrigo. Josi foi passar as festas com o irmão (também em acolhimento neste abrigo) na casa de uma família que não a sua. Já Maiara foi para a casa do irmão. Roberto sugere que eu só vá na semana seguinte, pois Josi já estaria de volta, mas não Maiara que só voltaria dali a um mês.

Chegando ao abrigo, percebo certa agitação e Roberto está de saída. Então, inicio a oficina com Gabriela, Josi e um rapaz que nunca havia participado desde então: Lucas ${ }^{26}$. Vou pessoalmente chamar Josi que está deitada no sofá parecendo estar muito mal humorada. Uma educadora já disse que a tinha chamado, mas Josi dissera que não participaria. Chego perto dela, pergunto se está tudo bem. Ela não quis se abrir, mas aceita meu convite para a oficina.

Gabriela conta que seus pais vieram vê-la no Natal. Ganhou presentes e matou um pouco das saudades. Parece mais falante e tranquila.

Assim que disponibilizo o material, Josi começa a desenhar imediatamente. Seu desenho parece com um buraco negro. Lucas diz que desenhará Saturno e seus anéis. Em seguida desenha um segundo planeta que lança raios para destruir Saturno. Depois, desenha personagens de um desenho japonês (Pokémon). Na hora da discussão, não quis comentar nada sobre seus desenhos e também não quis ouvir os outros.

Nesta oficina, Gabriela também não hesita ao iniciar seus desenhos. Começa fazendo uma casa com tinta branca numa folha branca. Uma educadora que observava, comenta que a menina está fazendo uma casa invisível. Gabriela termina seu desenho e faz outro. Pergunta para mim como se faz uma casa porque ela não

\footnotetext{
${ }^{26}$ Lucas tinha 16 anos e era portador de um tipo de deficiência intelectual que não foi possível saber ao certo do que se tratava, a coordenadora não soube dar maiores informações. Durante o período letivo, Lucas estudava à tarde, de modo que só pôde participar da oficina durante as férias.
} 
sabe. Conta que gostaria de fazer a casa da mãe. Falo a ela que só seu desanhar casas da mesma maneira que ela. Então, faz outro desenho. Quando vai falar de seu dele, diz que no primeiro, quis fazer uma casa de cachorro. Na segunda folha, faz seu nome muito grande de maneira que escreve "Gabriel", pois o "a" final, segundo ela, não coube na folha.

Josi fez seu desenho muito rapidamente e volta a assistir seu filme na sala. Após um tempo, ela mesma retorna e pergunta se a discussão não vai começar. Então, conta que fez o "buraco negro do tédio". Seu desenho chama a atenção de todos. Uma das educadoras que também fez desenhos nesta oficina comenta que, agora que colocou seu tédio num desenho, pode sorrir e ficar de bom humor. Apesar de Roberto não ter participado, duas educadoras, Meire e Cecília, ${ }^{27}$ fazem desenhos e participam da discussão, conferindo a esta uma dinâmica mais agitada e descontraída.

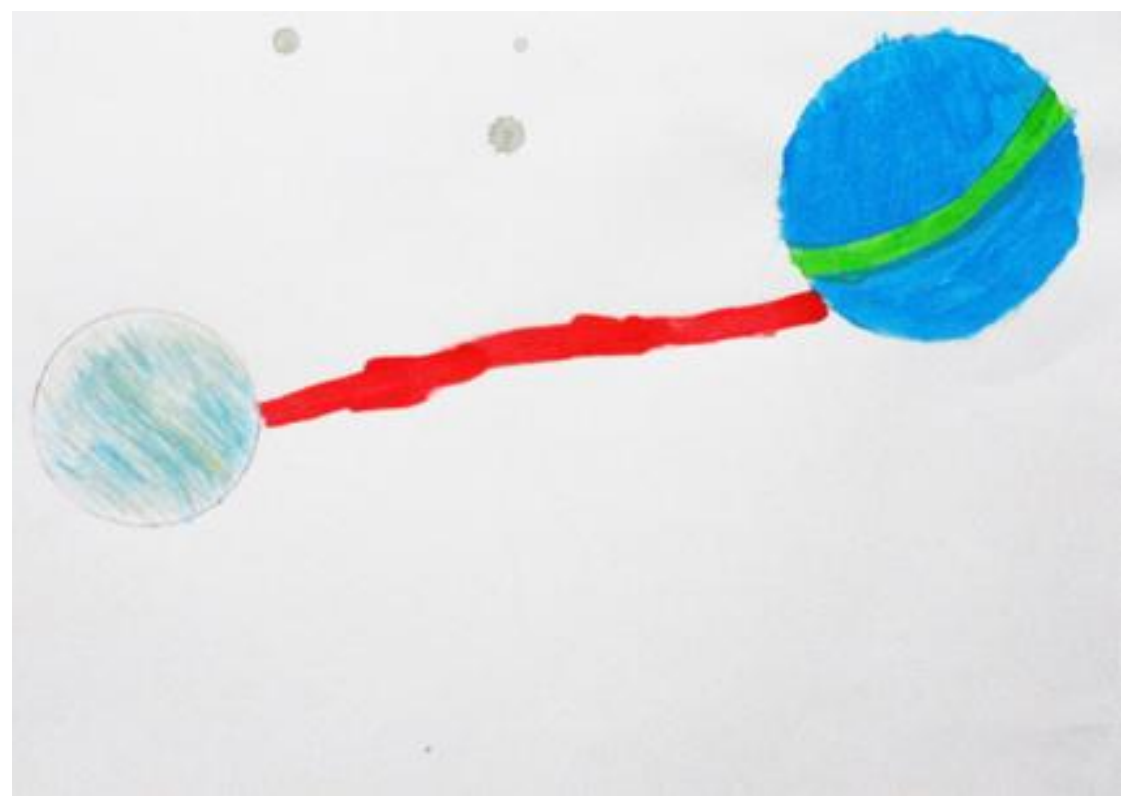

Figura 22 - Desenho 1 de Lucas no sexto encontro.

\footnotetext{
${ }^{27}$ Uma destas educadoras, Meire estava grávida, prestes a ganhar bebê. Tinha um comportamento muito expansivo, chamava bastante a atenção, falava alto e era muito animada. Desde o começo da atividade manifestava o desejo de participar dizendo que desenhava bem. A outra educadora, Cecília era mais reservada, mais séria e era possível notar que Maiara e Josi nutriam certa antipatia por ela. Foi esta segunda educadora que Maiara representou no seu desenho do primeiro encontro, onde se via um menino mandando uma educadora calar a boca.
} 


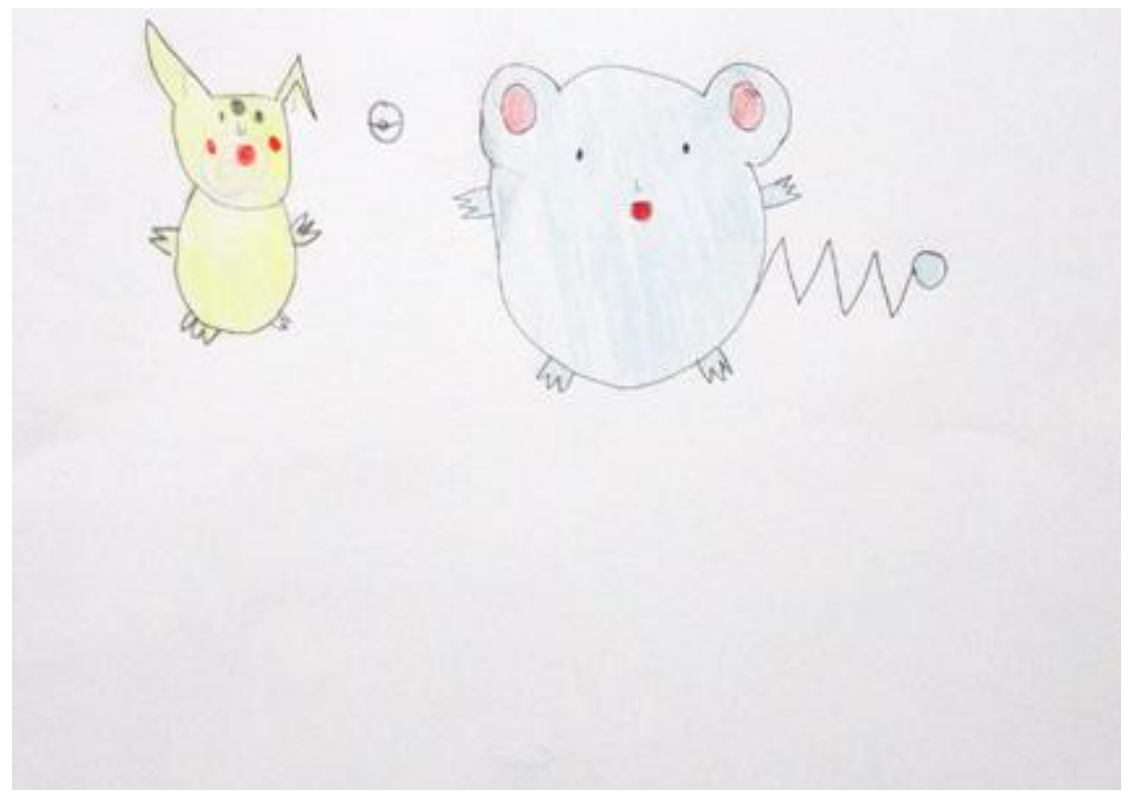

Figura 23 - Desenho 2 de Lucas no sexto encontro.

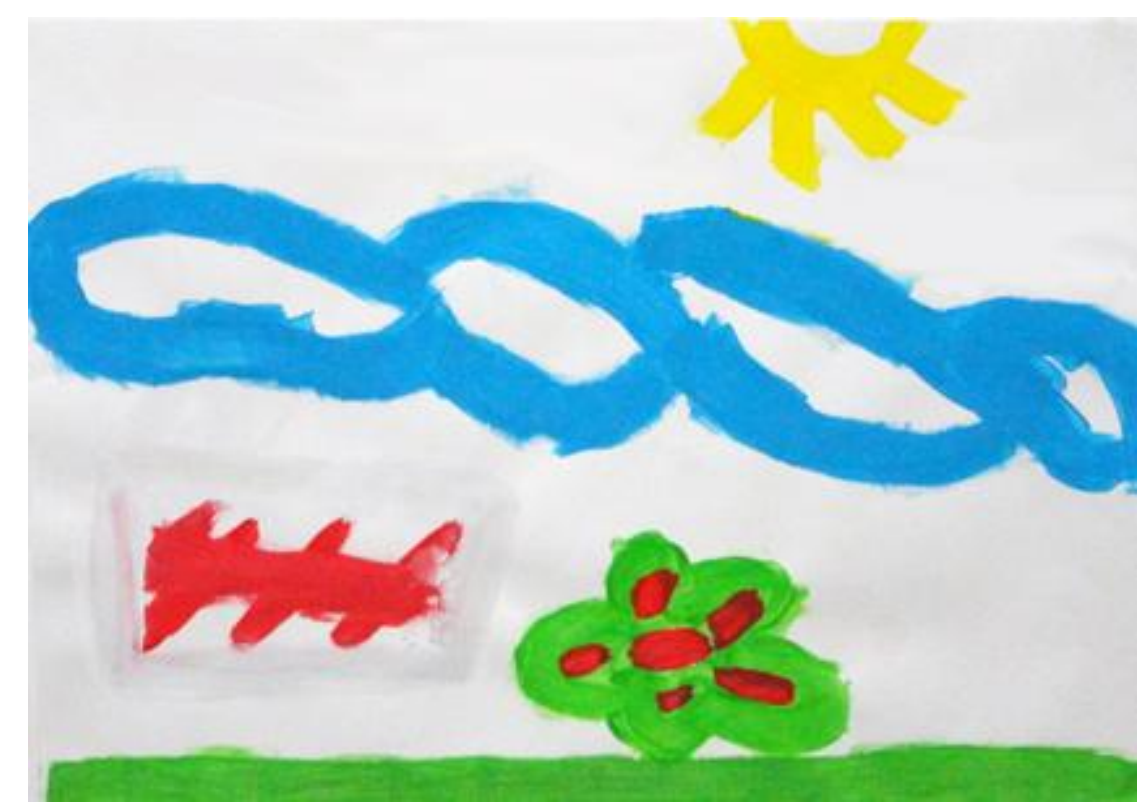

Figura 24 - Desenho 1 de Gabriela no sexto encontro. À esq., a "casa invisível". 


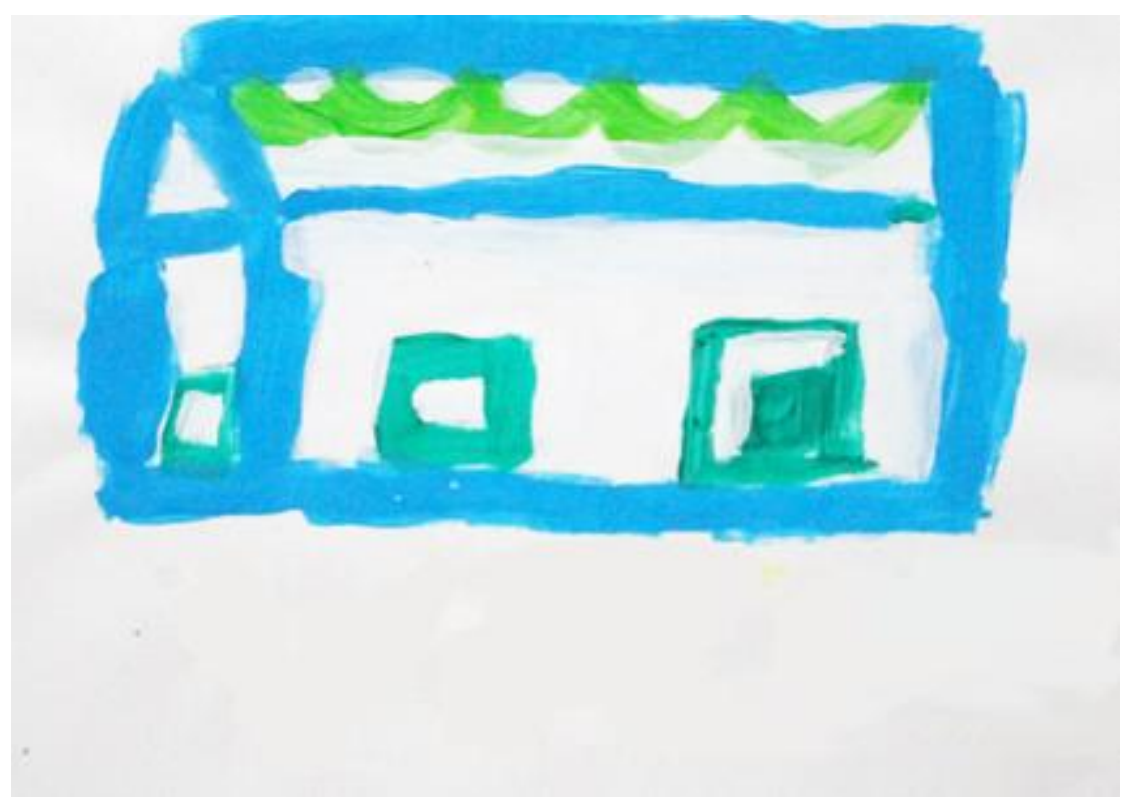

Figura 25 - Desenho 2 de Gabriela no sexto encontro.

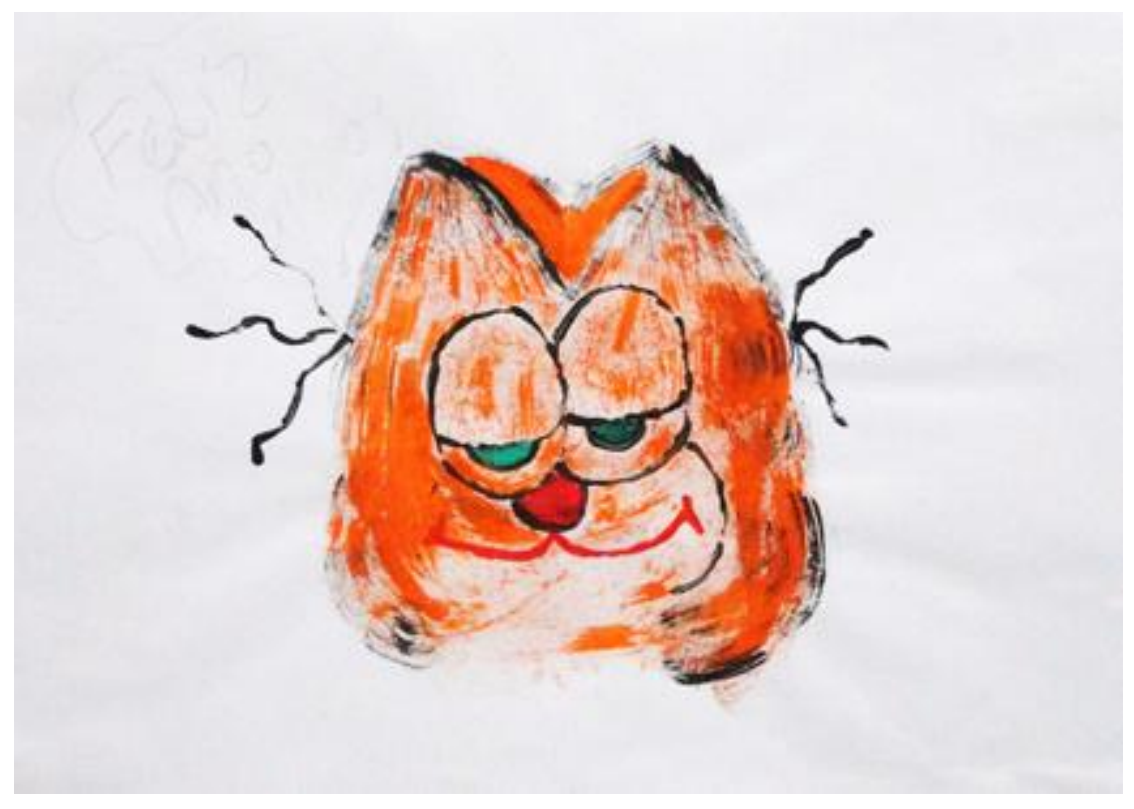

Figura 26 - Desenho da educadora Meire no sexto encontro. Do lado esq. se lê "Feliz ano novo". 


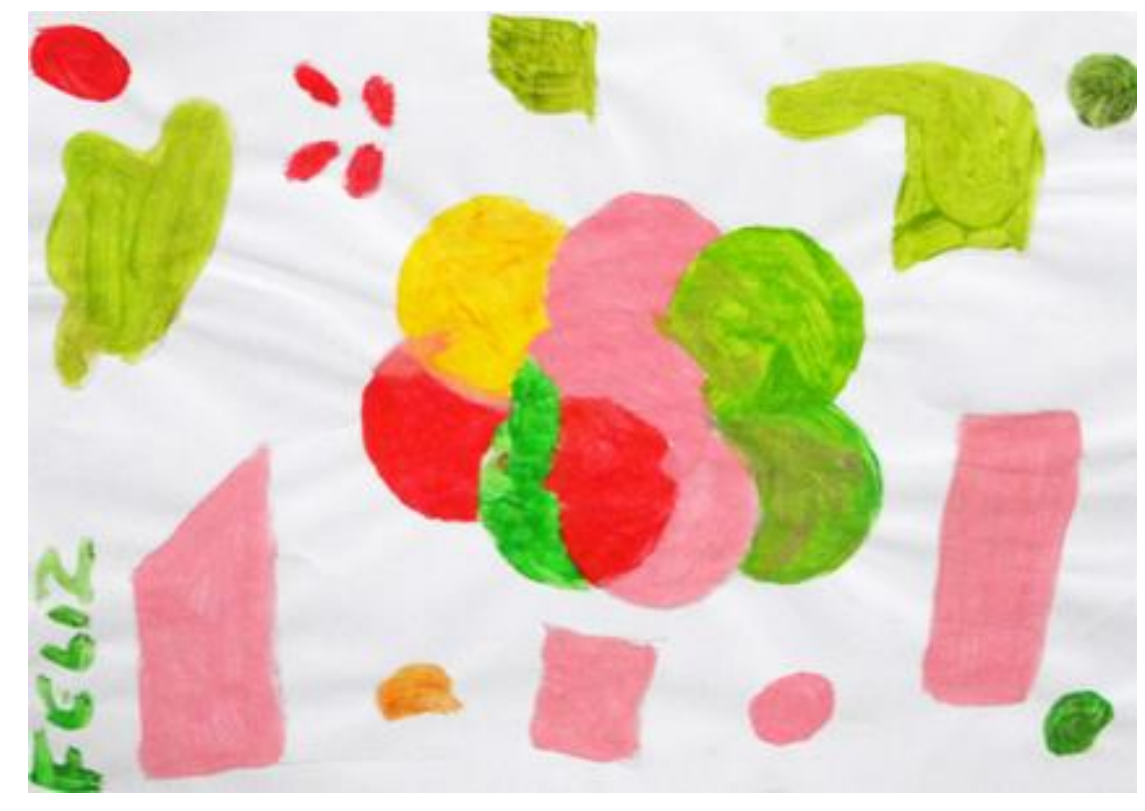

Figura 27 - Desenho da educadora Cecília no sexto encontro.

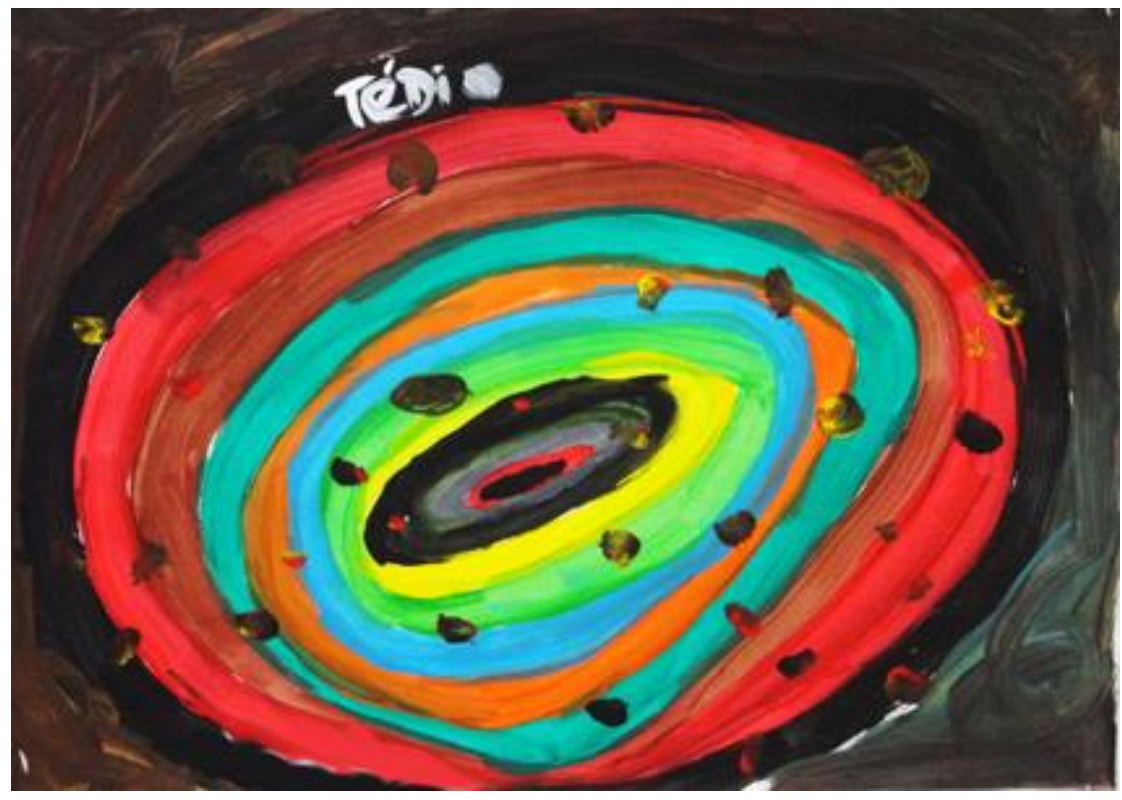

Figura 28 - Desenho de Josi no sexto encontro. 


\title{
SÉTIMO ENCONTRO
}

\author{
O desabafo de Josi
}

Assim que chego, encontro Roberto que se apressa para explicar a ausência da semana anterior. Josi está deitada no sofá assistindo a um filme. Vou chamá-la para participar e ela está ainda mais emburrada do que na semana anterior, mas mesmo assim, vem. Fica meio prostrada na mesa, todos já pegaram seus papéis, já começaram a desenhar, menos ela. Como estou próxima às folhas, pergunto se ela quer que pegue uma folha. Josi me pede a folha preta e começa a escrever muitas coisas. Quando termina, pergunto se posso ler, ela concorda e enquanto leio, seus olhos ficam marejados. Digo que ela parece estar muito triste, pergunto se gostaria de conversar, mas ela diz que não e decide voltar a ver seu filme na sala enquanto os outros ainda não terminaram.

Gabriela está muito agitada. Muito falante, faz mais de um desenho. Em um de seus desenhos representa Roberto e outras duas educadoras. Todos parecem meio monstruosos: com vários braços e pernas além dos olhos grandes. Diverte-se ao dizer que vai desenhar Paula - umas das educadoras - na semana seguinte com dez pernas.

Outra adolescente que nunca havia participado está presente: Daniela ${ }^{28}$ tem 18 anos e se senta ao meu lado. Inicialmente não sabe o que desenhar. Lucas está sentado a sua frente e desenha uma bandeira do Brasil. Ela também resolve fazer o mesmo, mas atrapalha-se um pouco. Sugiro que crie uma bandeira nova. Ao todo, fez três desenhos neste dia, mas o último decidiu dar para Roberto: um coração.

Assim que Josi se retira da mesa, Daniela pergunta o que a outra adolescente escreveu na folha preta. Então leio em voz alta já que Gabriela também quer saber. Ao terminar a leitura, comento que Josi deve estar muito chateada e com raiva. Então Daniela conta que sentiu muita raiva naquele dia, pois foi ofendida por outra adolescente da casa. E comenta que, mesmo tomando remédio "para não bater", quase bateu na sua ofensora. Então, Daniela pergunta para que serve o remédio

\footnotetext{
${ }^{28}$ Assim como Lucas, Daniela também é portadora de alguma deficiência intelectual. Os dois estudam na mesma escola. Por ter aulas no período da tarde, só pode participar da Oficina durante as férias. Já estava abriga na instituição anterior junto com Josi e Maiara. Por já ter completado 18 anos, estava sendo preparada para o desacolhimento.
} 
que Roberto Ihe dá todos os dias. Ele responde que é "calmante" e ela completa: "para ajudar a não bater". Então, Gabriela e Lucas também fazem a mesma pergunta em relação a eles próprios e obtém a mesma resposta.

No momento de comentar, Daniela fica em pé e à frente de todos. Explicou que no desenho da bandeira havia uma estrela que simbolizava Roberto, pois ele era um irmão, um pai para ela. Isso porque cuidava dela: a levava ao médico, dava remédio, levava ao dentista. Diz que, Josi seria a árvore (do segundo desenho), mas esqueceu de desenhar as maçãs, porque Josi é sua amiga. Conta que na noite anterior, as duas dormiram na sala assistindo filme. Neste momento, Josi que está presente dá um sorriso. Então pergunto quem seria Gabriela. Daniela afirma que Gabriela seria a nuvem, mas não explica o porquê. Lucas ficou meio alheio. Fez seu desenho e muitas brincadeiras para "tirar sarro". Porém, como na oficina anterior, não se envolveu na discussão. Também desenhou Roberto, mas nada quis dizer a respeito.

Roberto contou que fez uma vila. Daniela pergunta se ele desenhou sua própria casa. Ele diz que não. Josi não quer falar nada sobre o que escreveu. Então conto o comentário de Daniela sobre a raiva que sentiu quando foi ofendida. Daniela começa a fazer uma preleção sobre falsas amizades e Josi faz um comentário concordando um pouco irônica, dando a entender que ela conhece falsas amigas. Josi não fica até o final dos comentários, mas antes de se retirar sento-me ao seu lado e pergunto o que está acontecendo, coloco-me à disposição se quiser conversar após a oficina, mas ela não quer.

O desenho de Josi chama muito a atenção de todos que passam. As educadoras passam, se surpreendem, perguntam quem fez aquilo. Na verdade, parece que esta foi mesmo a intenção de Josi. Paula pega a folha e lê e Roberto faz o mesmo. Quando todos já se retiraram e estou limpando e organizando os materiais, Roberto se aproxima e diz que Josi está deste jeito desde a semana anterior. No almoço demonstrou seu descontentamento quando uma adolescente sentou-se e aproximou-se carinhosa da diretora do abrigo. Roberto fala que ela é muito ciumenta. Fica com raiva de qualquer pessoa que se aproxime daqueles de quem gosta. Parece que Josi não sabe se fazer notar de uma forma carinhosa, então faz coisas chocantes. 
Paula vem conversar comigo sobre Josi. Mostra-se muito sensível e atenta. Pergunto-Ihe se Josi não estaria com saudades de Maiara. Paula acha que é muito possível e se compromete a conversar com ela a respeito. Quando já estou prestes a ir embora, cruzo com Josi e ela está visivelmente mais animada ao me despedir, ela responde: "Vai com Deus".

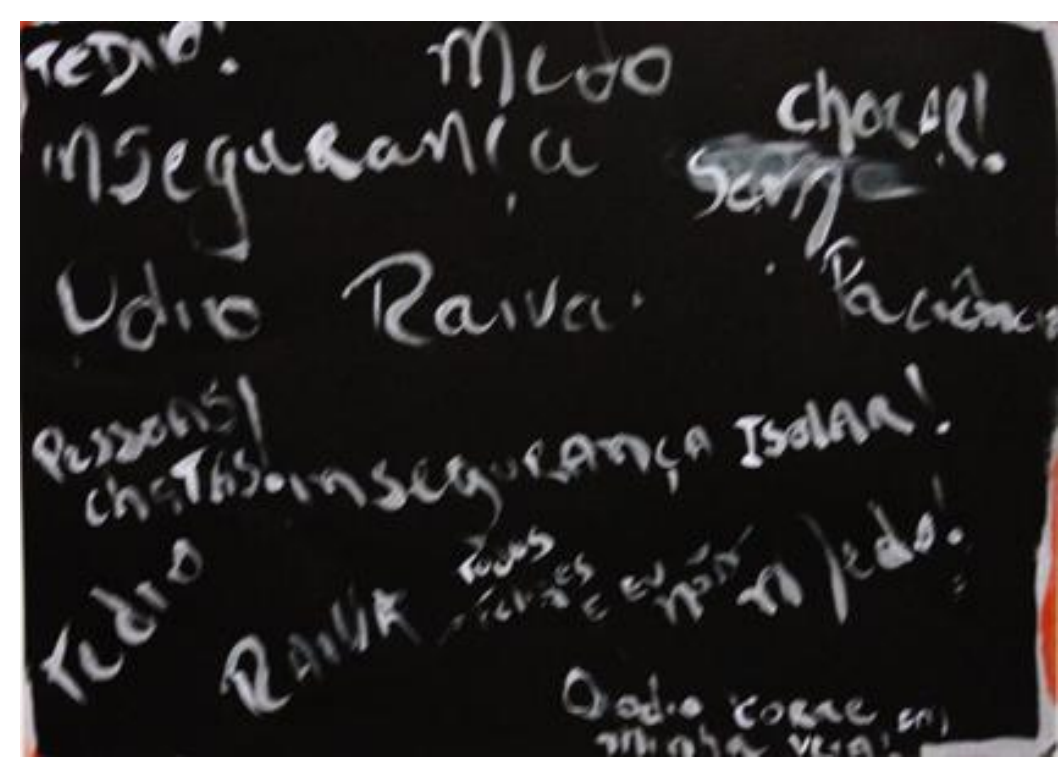

Figura 29 - Desenho de Josi no sétimo encontro. Lê-se; "Tédio", "medo", "insegurança", “ódio", "raiva"; "sem paciência”, "chorar!”, "pessoas chatas", "isolar!”, “todos felizes e eu não”, “o ódio corre em minha veia”.

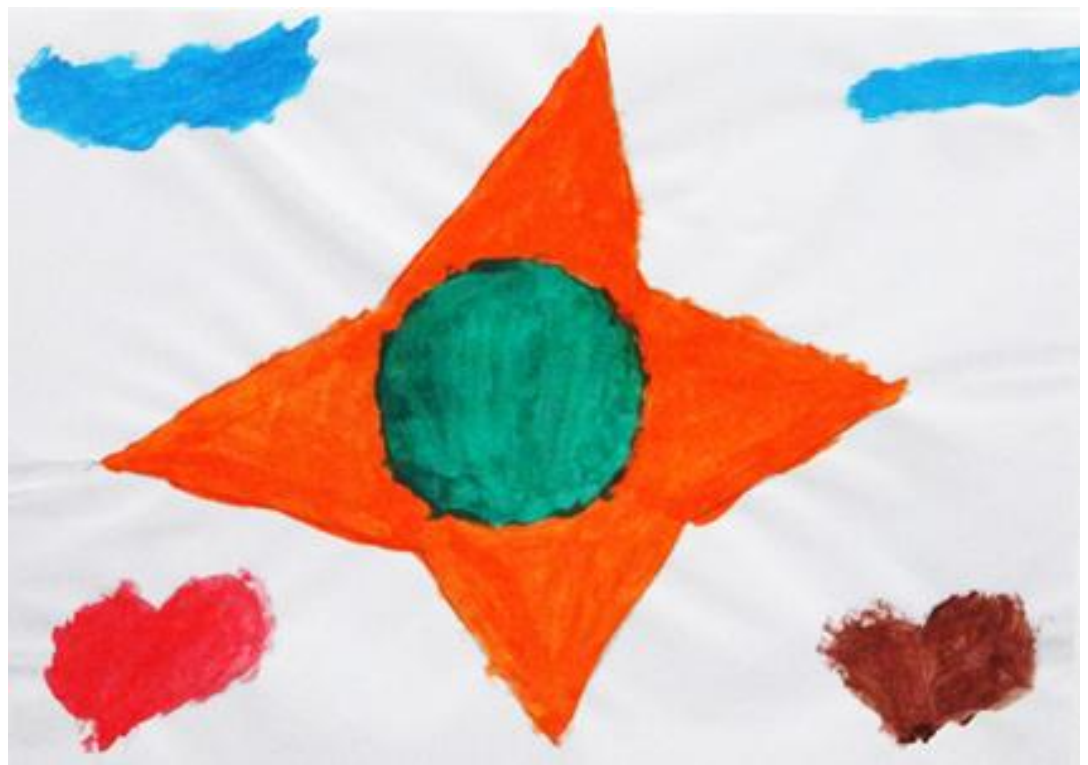

Figura 30 - Desenho 1 de Daniela no sétimo encontro. 


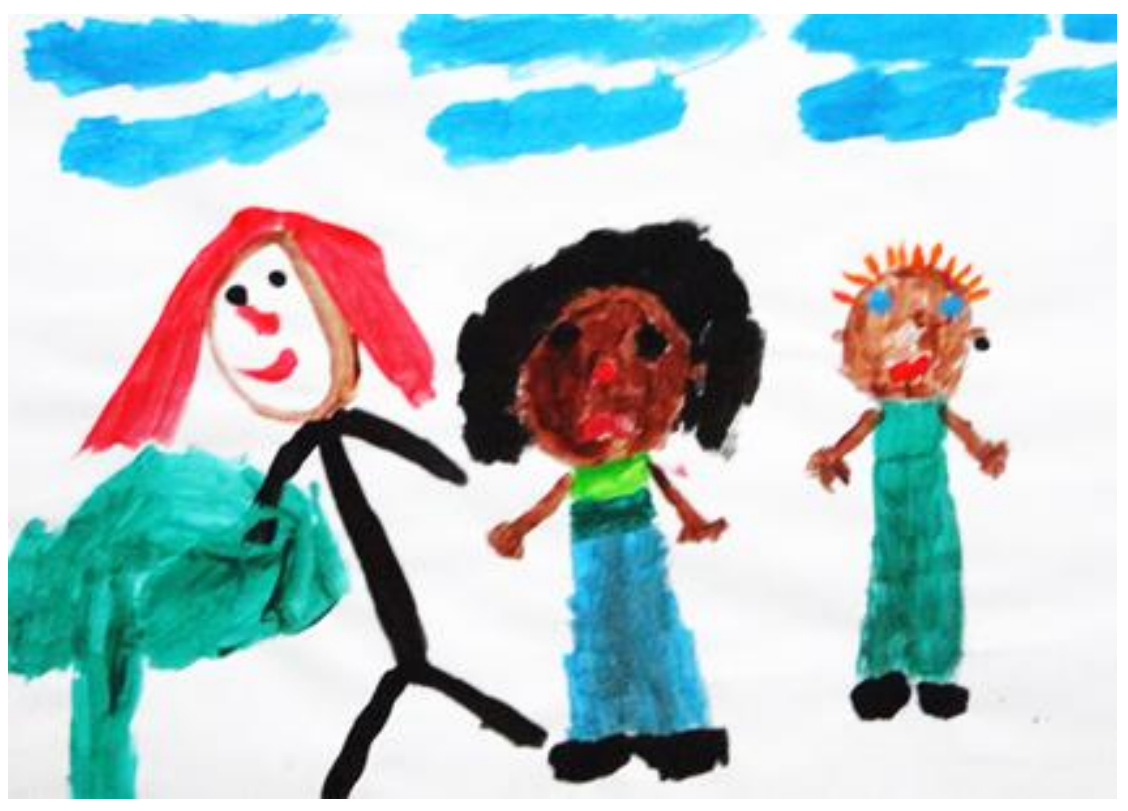

Figura 31 - Desenho 2 de Daniela no sétimo encontro.

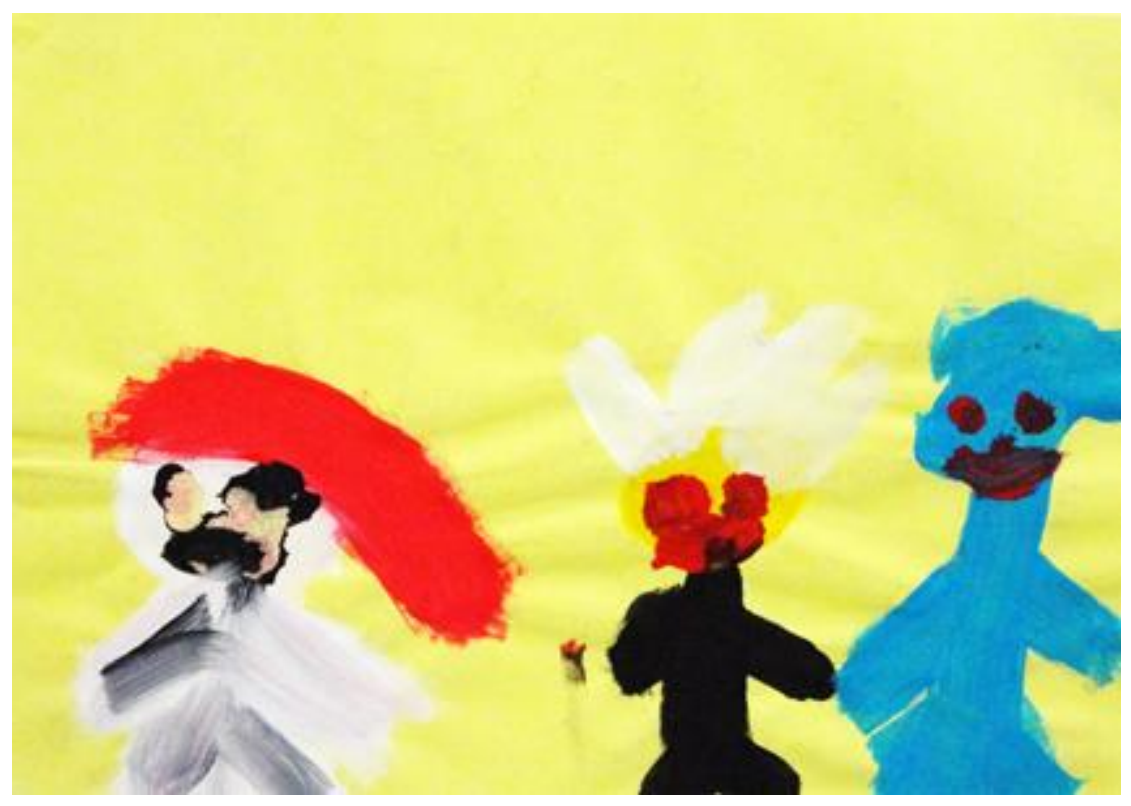

Figura 32 - Desenho 1 Gabriela no sétimo encontro. 


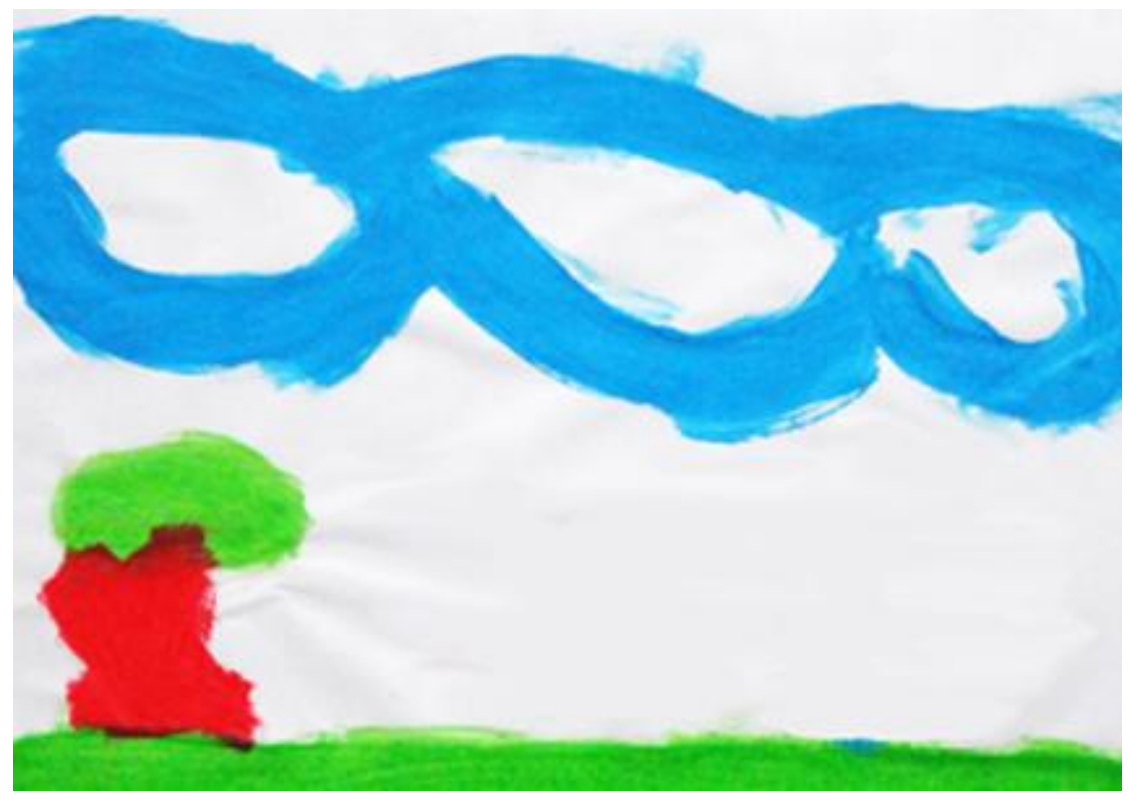

Figura 33 - Desenho 2 de Gabriela no sétimo encontro.

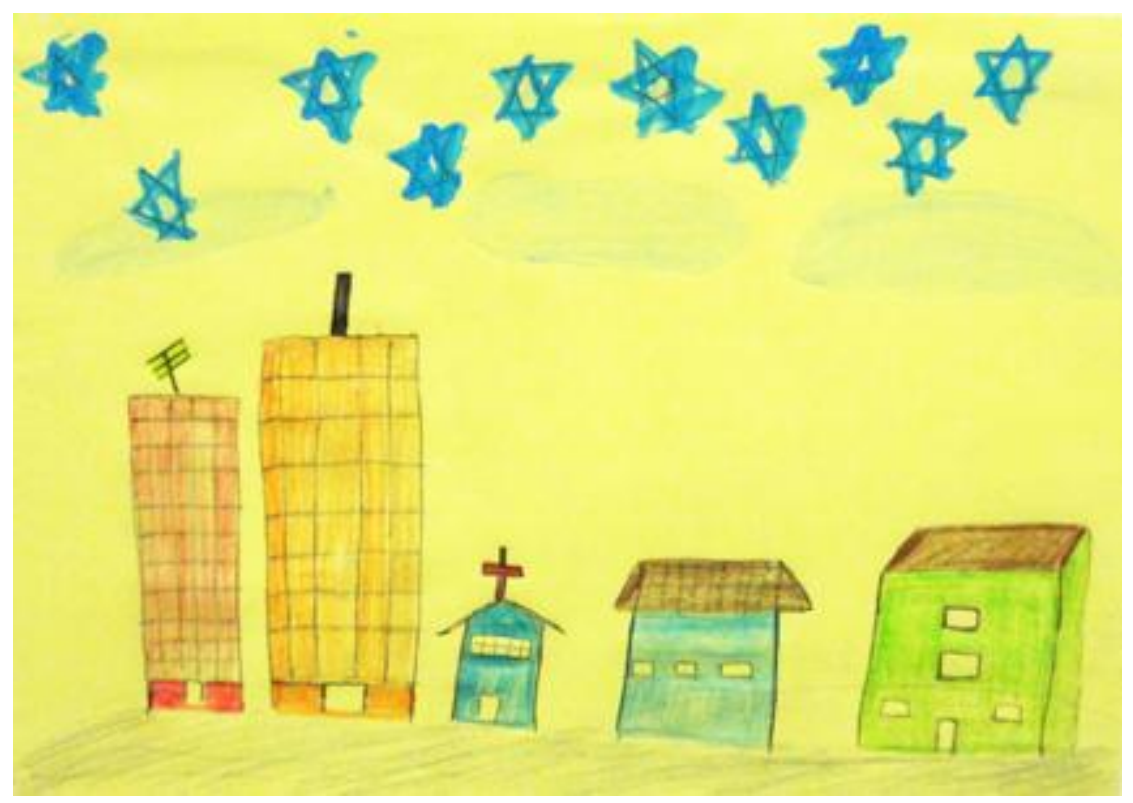

Figura 34 - Desenho de Roberto no sétimo encontro. 


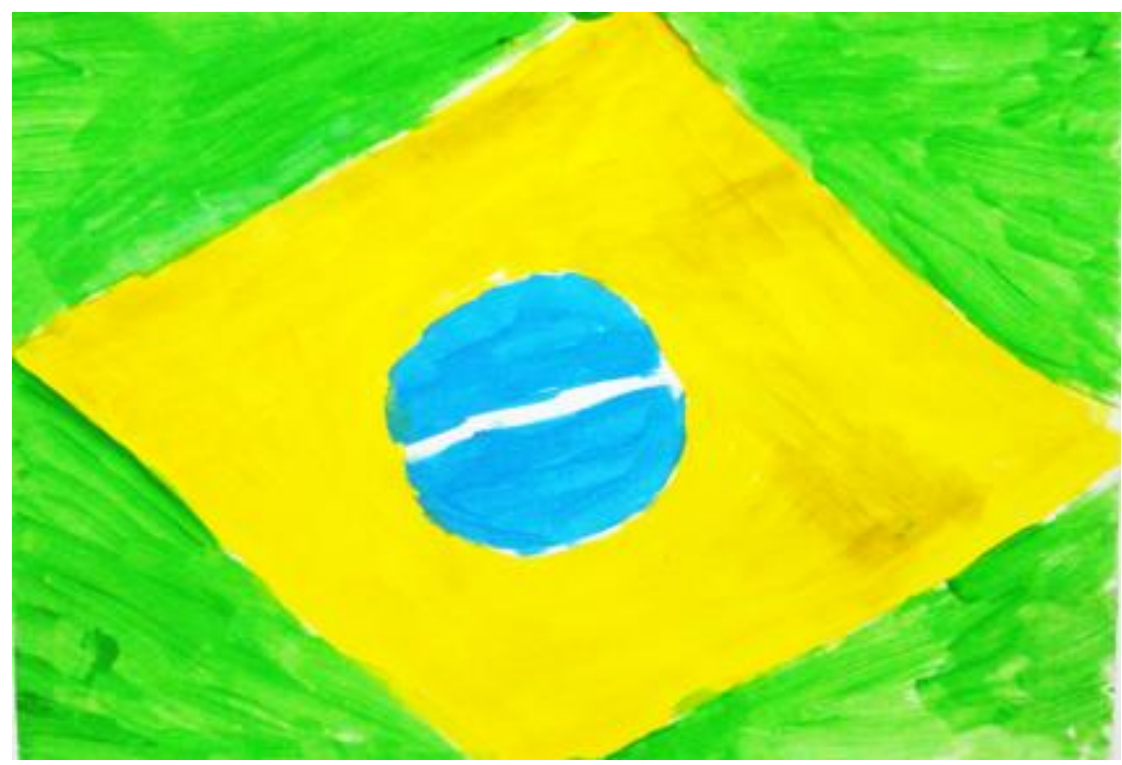

Figura 35 - Desenho 1 de Lucas no sétimo encontro.

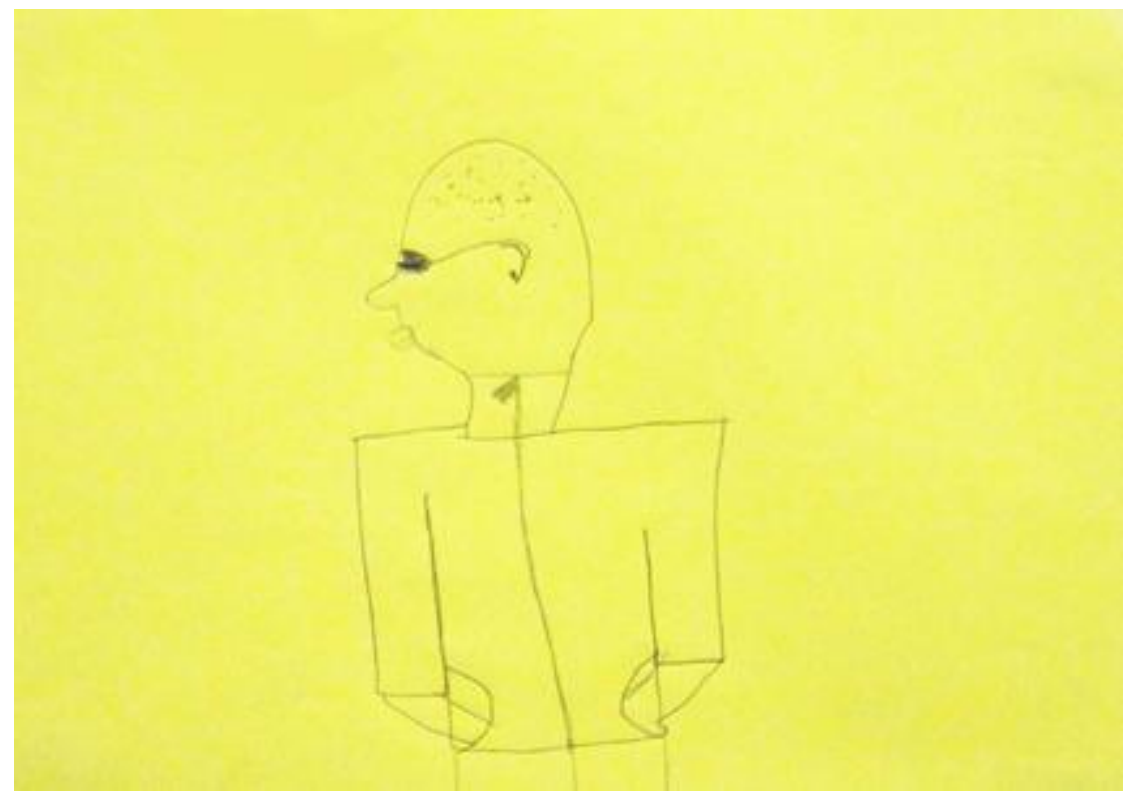

Figura 36 - Desenho 2 de Lucas no sétimo encontro. Representação de Roberto. 


\section{OITAVO ENCONTRO}

"Você está demitida!"

Ao chegar, encontro Lucas no portão. Estou um pouco atrasada e ele me diz: "Você está demitida!". Percebo a importância do setting e que talvez, ele estivesse no portão me esperando. Peço desculpas e explico que o trem veio muito devagar e peço, por favor, que ele me readmita. Ele concorda.

Ao entrar no refeitório, Daniela está chegando e diz: "Cheguei, Aline!" Então chega Josi sorridente. Nunca a tinha visto tão radiante e me surpreendo. Digo que está muito bonita e ela diz que naquele dia estava bem melhor. Em seguida entra Gabriela que se senta à mesa. Josi está particularmente colaborativa: forra a mesa com jornal, distribui as tintas e as folhas de papel. Roberto chega atrasado, faz um desenho rapidamente e sai.

Esta oficina teve vários participantes: Josi, Daniela, Gabriela, Roberto, Lucas, Paula e mais duas educadoras. E consequentemente muitos desenhos. Não só pelo número de pessoas, mas cada adolescente fez mais de um desenho.

Percebo que Roberto está inquieto. Faz um desenho muito rapidamente e sai. Depois disto, passa pelo refeitório diversas vezes. As educadoras (Meire, Paula e Cecília) estão animadas por estarem participando. Em determinado momento, Roberto surge sério e diz que os quintais precisam ser lavados e que precisa de duas delas. Meire pergunta se precisa ser naquele momento e ele se isenta dizendo que foram ordens da diretora do abrigo e sai. O clima repentinamente fica tenso. As crianças ficam quietas. As educadoras reclamam, pois queriam continuar a participar. Meire e Cecília saem e apenas Paula continua a desenhar. Ao fim, converso com Roberto que se queixa pelo fato das educadoras estarem desenhando e não cuidando dos seus afazeres.

Josi fez três desenhos. Em um deles representou uma casinha e disse que seria sua futura casa. Pergunto como ela a imagina: "Antiguinha, com piso de madeira, roxa por fora e clarinha por dentro". Quem moraria com ela? "Meu irmão e Maiara. Já falei para ela falar com a mãe dela. Se ela [mãe] deixar...". No desenho 
anterior escreveu: "Volta às aulas" e uma frase quase ilegível. Quando foi colocar seu desenho na parede, perguntei o que ela havia escrito e Josi disse que depois diria. No momento de contar, falou que não se lembrava, hesitou, até que finalmente se "lembrou" e disse; "Saudades da Maiarinha". Houve uma tentativa de dizer o que sentia em relação à Maiara, mas percebo o quanto é difícil.

A volta às aulas representava o regresso de Maiara ao abrigo. Pergunto se, aquele mau humor das últimas semanas não seriam saudades de Maiara e Josi acha que sim. Pergunto se não se falam por telefone, mas Josi diz que não podem.

Gabriela continua desenhando os educadores com cores fortes e formas bizarras. Pergunto se desenha assim todas as pessoas ou só os educadores. Ela responde com veemência que só os educadores. Fica a sensação de, ao ir para o abrigo, Gabriela se deparou com um mundo muito diferente e as pessoas daquele mundo são todas meio esquisitas para ela, que ainda está tentando se acostumar.

Daniela conta sobre seu namorado. Desenha Paula e sua família. Ao final, pede para fazer um coração e diz que dará o desenho para Roberto.

Paula desenhou seu trajeto de casa até o abrigo: levando seu filho para a escola no meio do caminho para o trabalho. Paula traz algo semelhante a Roberto em seus primeiros desenhos: a vida pessoal entremeada pela vida no abrigo. Daniela se interessa muito em saber sobre a vida de Paula, se alguma vez, o seu filho já foi ao abrigo. Paula responde que nunca o levou.

Quando já estou guardado todo material, Paula se aproxima e conta que conversou com Josi na semana anterior. A adolescente lhe disse que estava com muita raiva e Paula lhe perguntou se não seriam saudades de Maiara. Josi disse que sim e Paula lhe disse que cada um tem uma forma de demonstrar o que sente. Josi diz que, algumas crianças da casa aprontam para chamar a atenção, mas que ela chamaria a atenção sendo gentil com os outros e após esta conversa conseguiu pedir para Paula Ihe fazer companhia, algo difícil de acontecer. Paula conta muito entusiasmada o quanto a sua conversa com Josi foi importante. Josi ficou até o final da oficina, guardou tudo e de fato, chamou a atenção pela sua gentileza. 


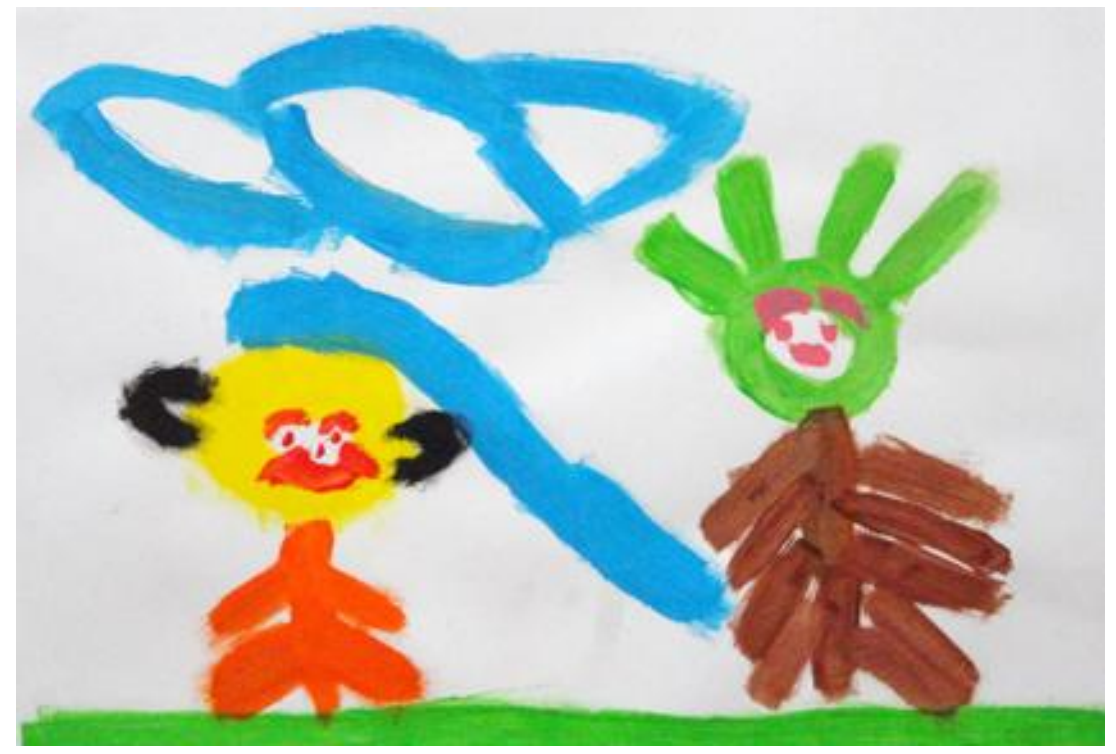

Figura 37 - Desenho 1 de Gabriela no oitavo encontro. Representando educadores do abrigo.

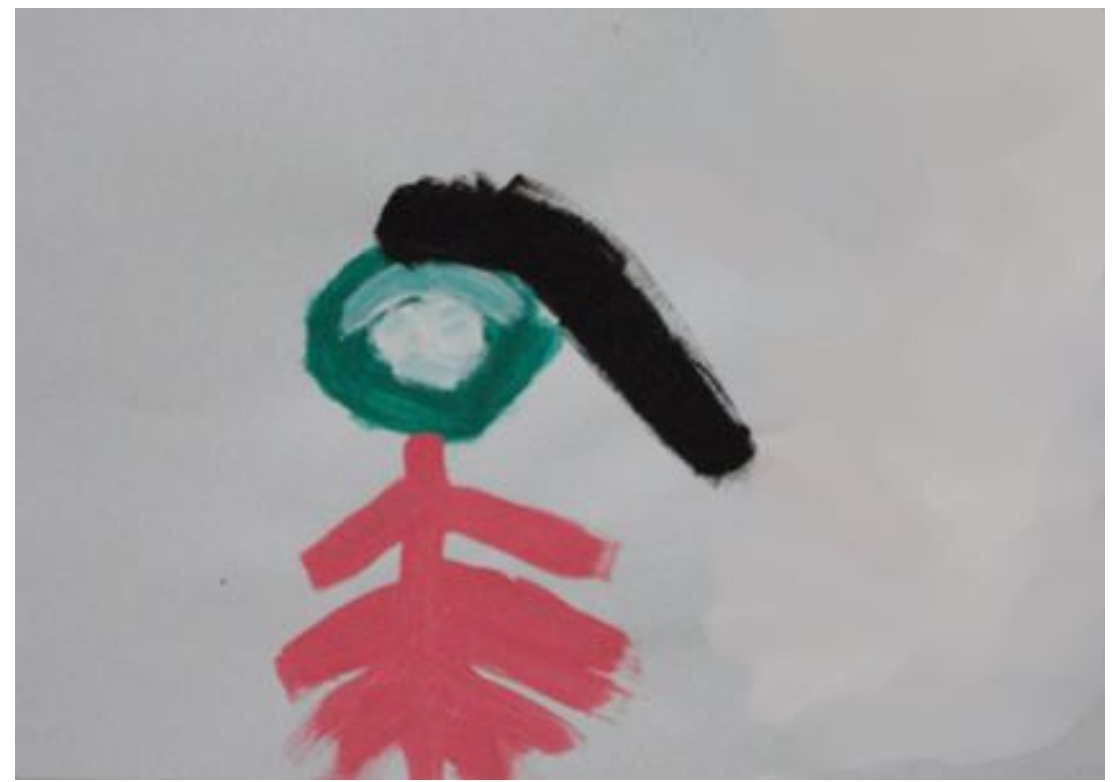

Figura 38 - Desenho 2 de Gabriela no oitavo encontro. Representando Paula. 


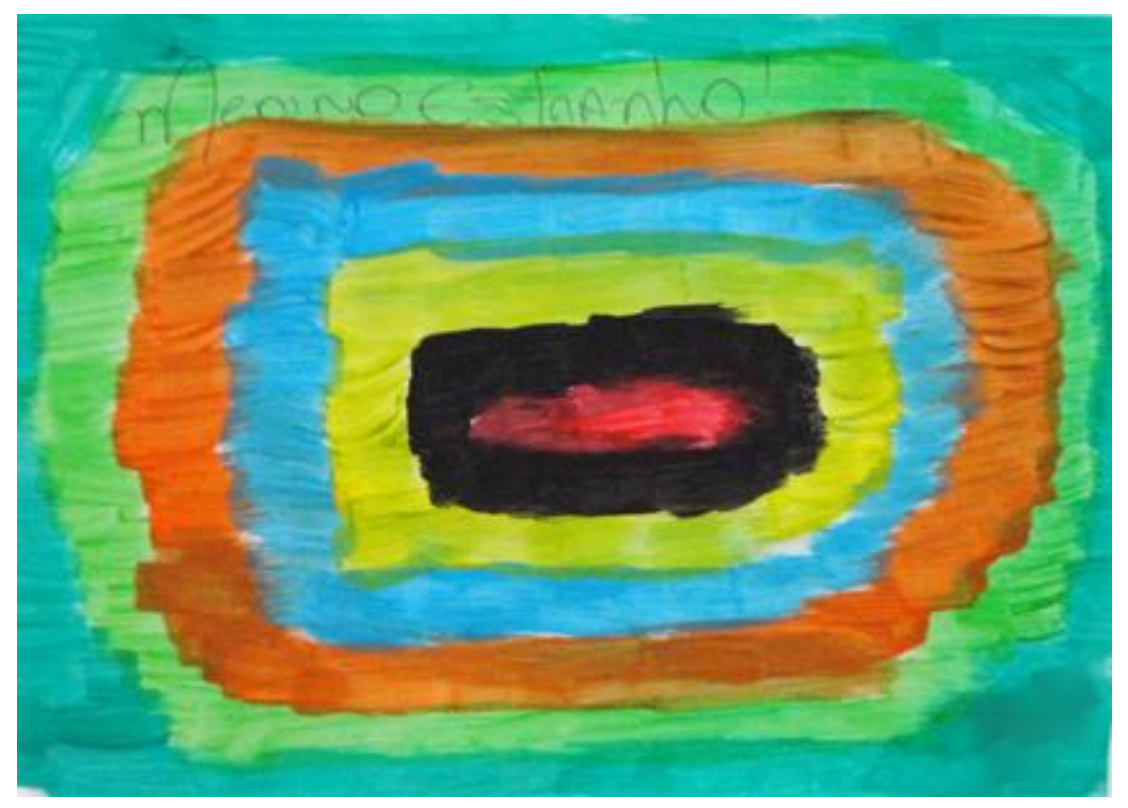

Figura 39 - Desenho 1 de Josi no oitavo encontro. Onde se lê "menino estranho" ${ }^{29}$

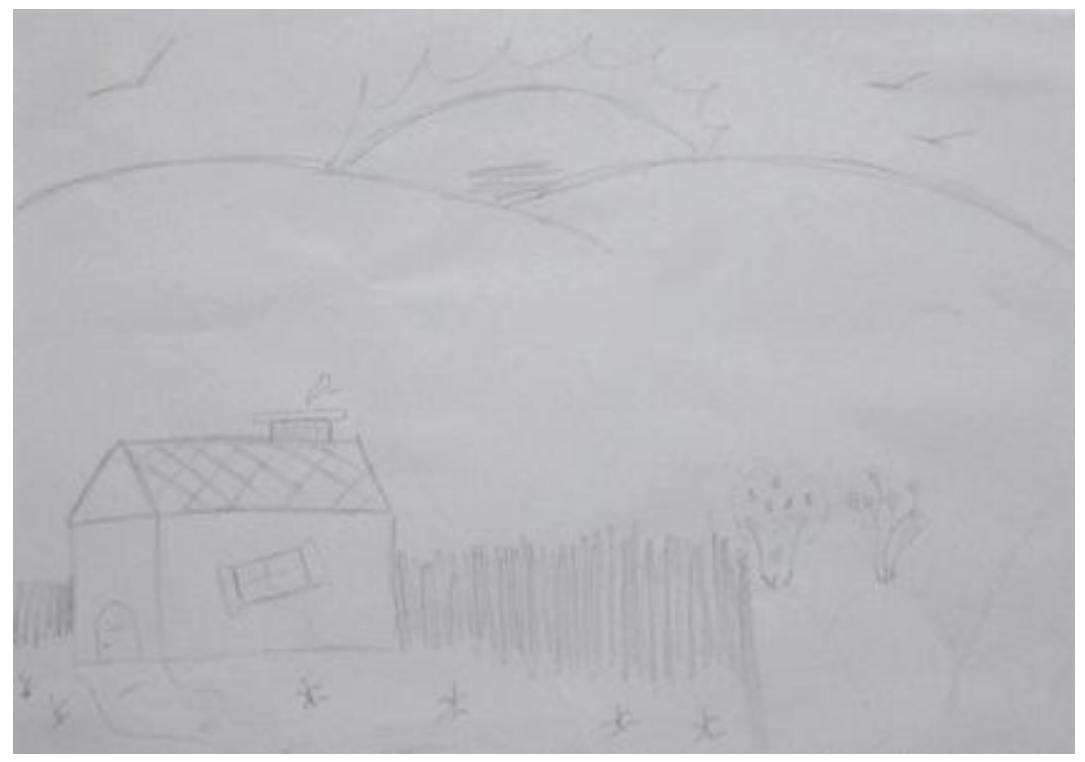

Figura 40 - Desenho 2 de Josi no oitavo encontro.

\footnotetext{
${ }^{29}$ Neste dia, havia na casa um adolescente novo Leandro. Tinha mais ou menos 15 anos, voz e comportamento efeminados. No início não podia participar da Oficina, observando a atividade pelo vitrô que separava a cozinha do refeitório. Neste dia, Leandro estava circulando pela casa e cada vez que passava, Josi o olhava como se estivesse "caçoando" dele. Mesmo quando pergunto sobre o "o menino estranho", Josi não fala nada, mas por seu comportamento, tudo leva a crer que falava de Leandro. Esse estranhamento em relação a ele ressurge no último encontro, quando participa pela primeira vez.
} 


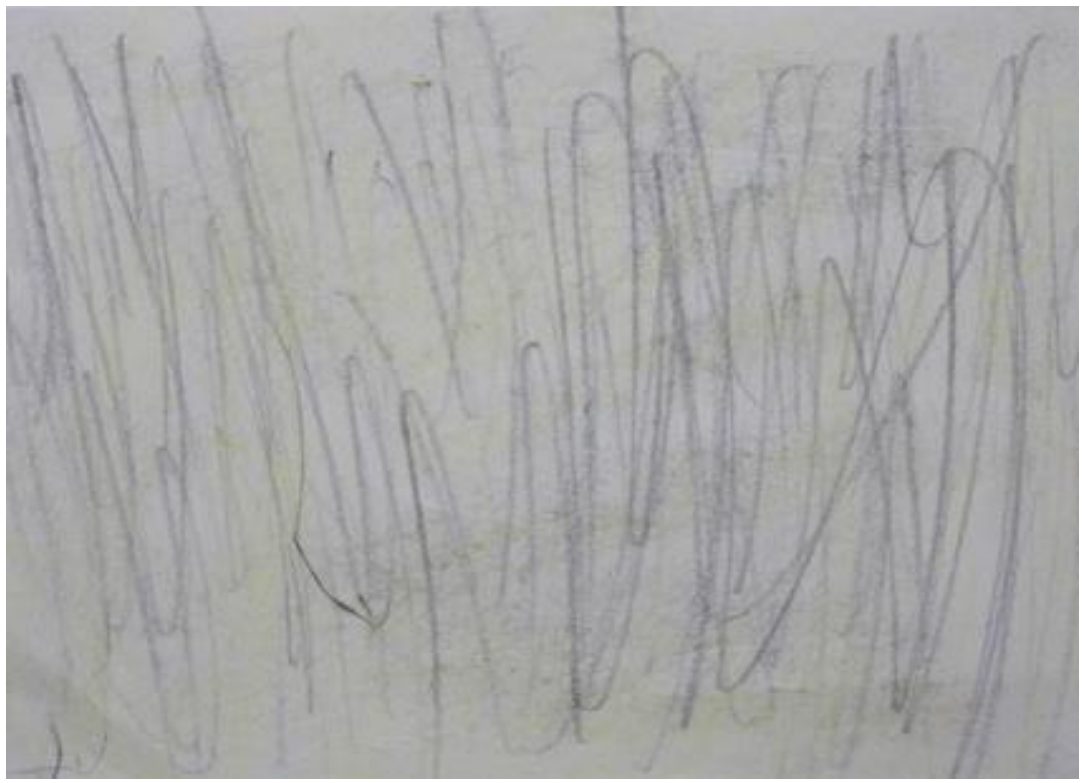

Figura 41 - Desenho 3 de Josi no oitavo encontro.

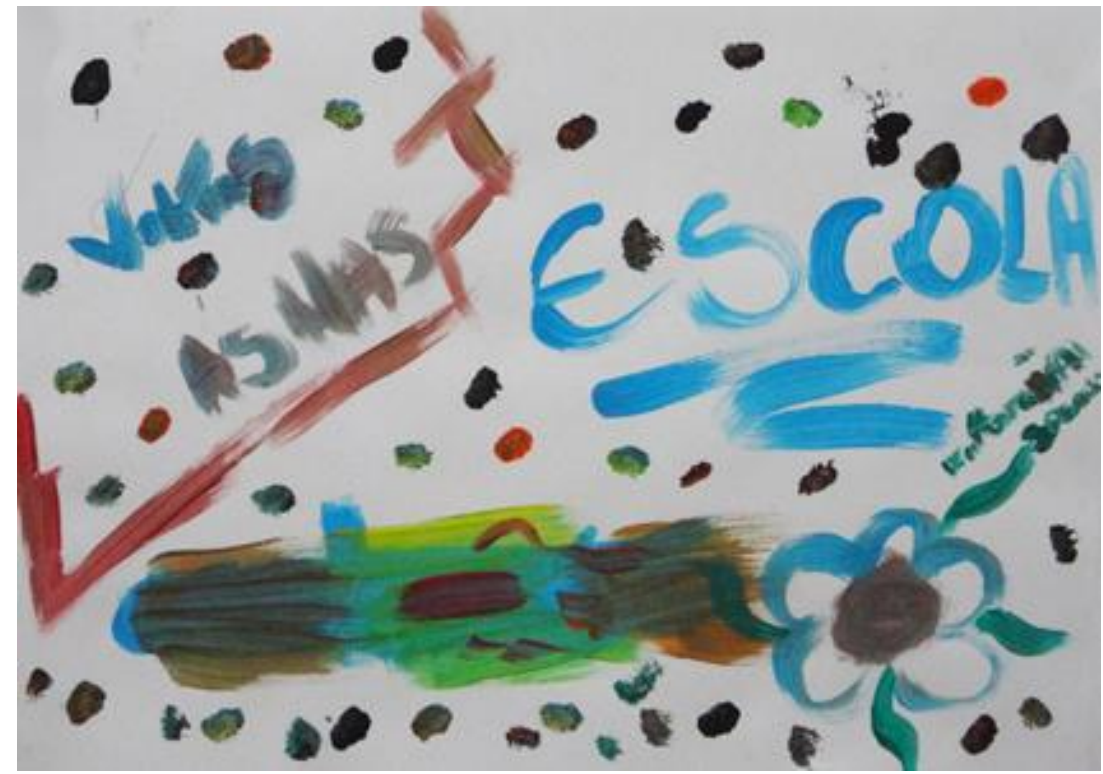

Figura 42 - Desenho 4 de Josi no oitavo encontro. No lado direito, está escrito de forma quase ilegível: "Saudades da Maiarinha". 


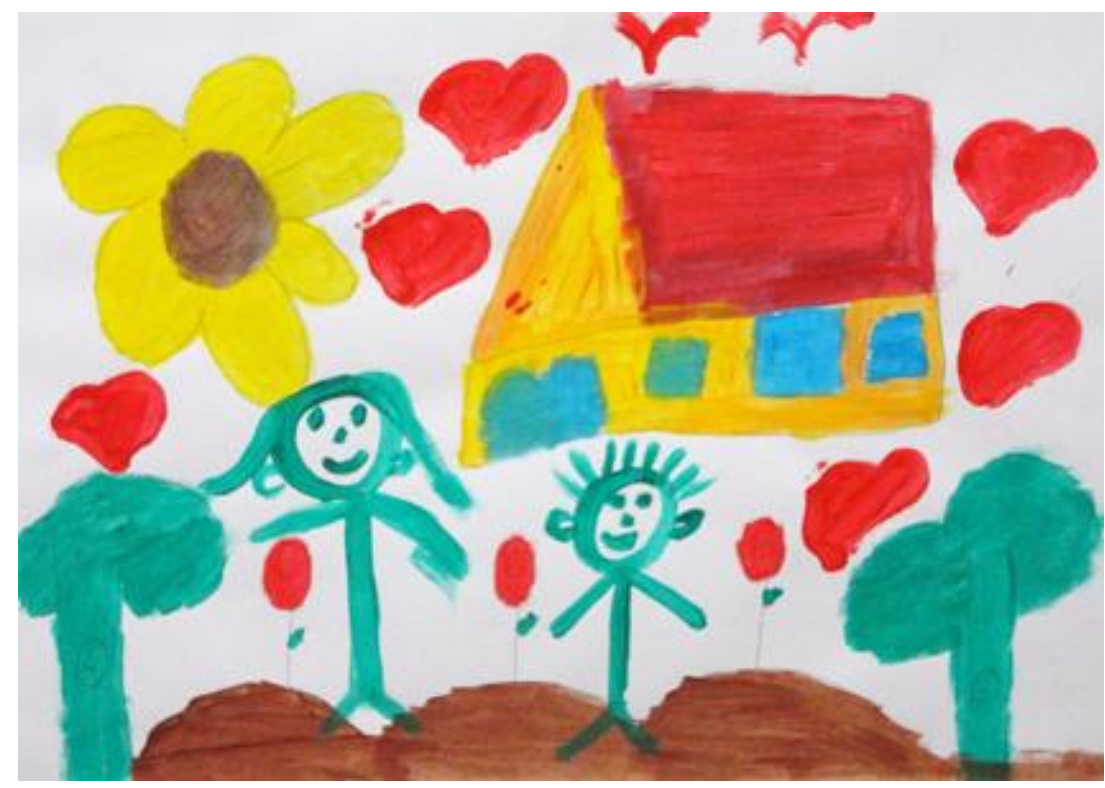

Figura 43 - Desenho 1 de Daniela no oitavo encontro. Representando Paula e seu filho.

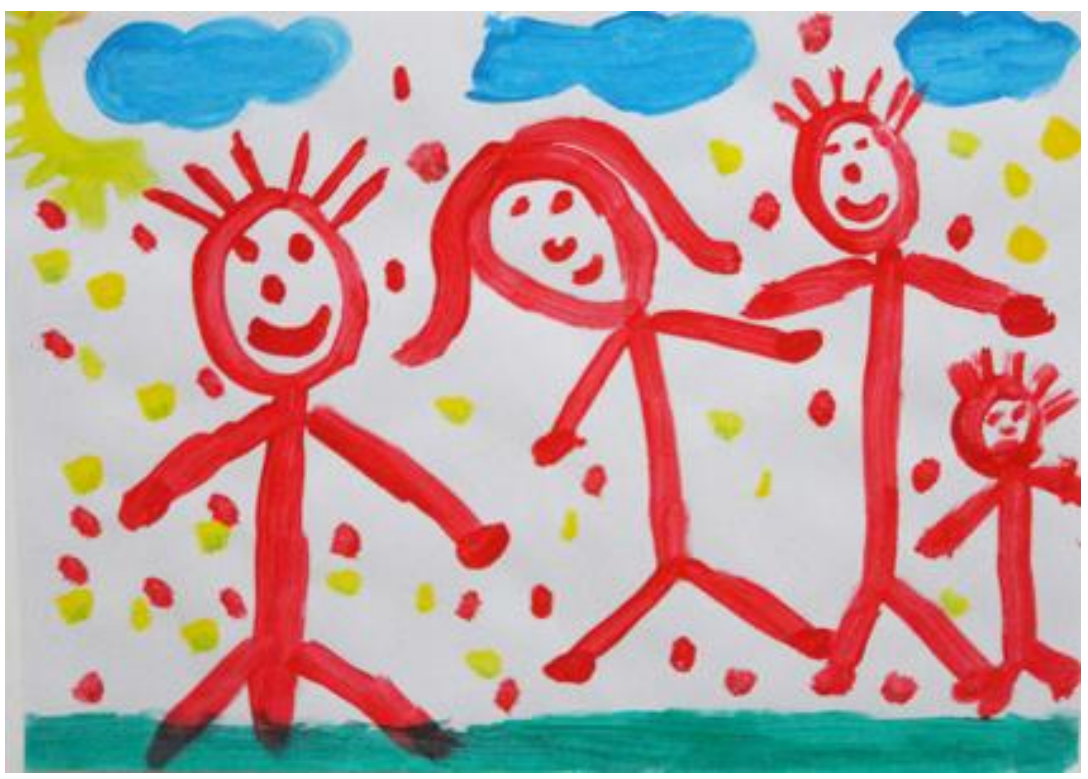

Figura 44 - Desenho 2 de Daniela no oitavo encontro. Representando

Roberto, o irmão dele, ela mesma e um dos sobrinhos de Roberto. 
Figura 45 - Desenho de Roberto no oitavo encontro.

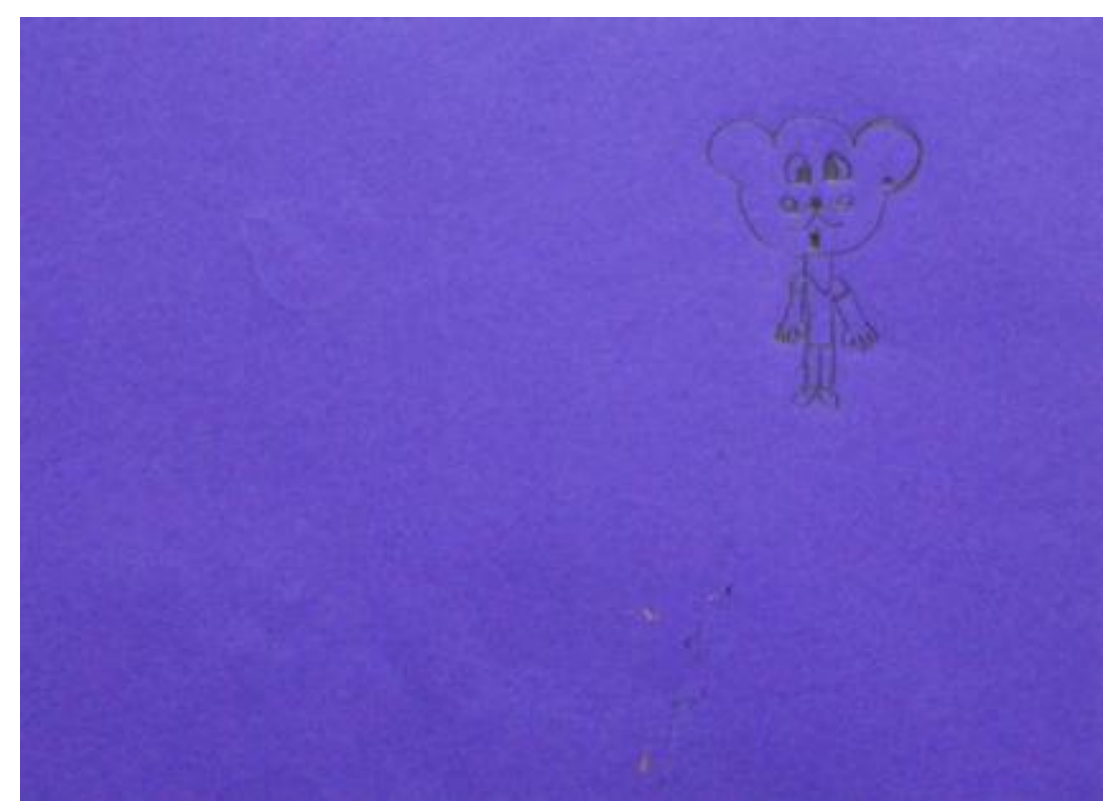

Figura 46 - Desenho 1 de Lucas no oitavo encontro. 


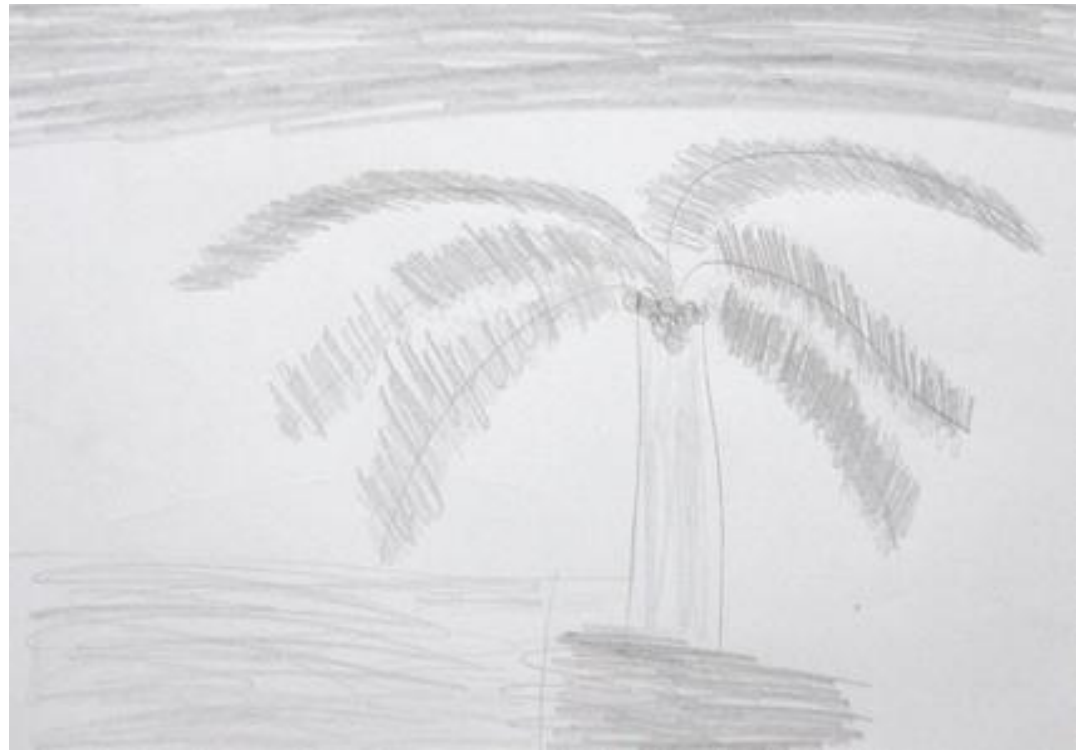

Figura 47 - Desenho 2 de Lucas no oitavo encontro.

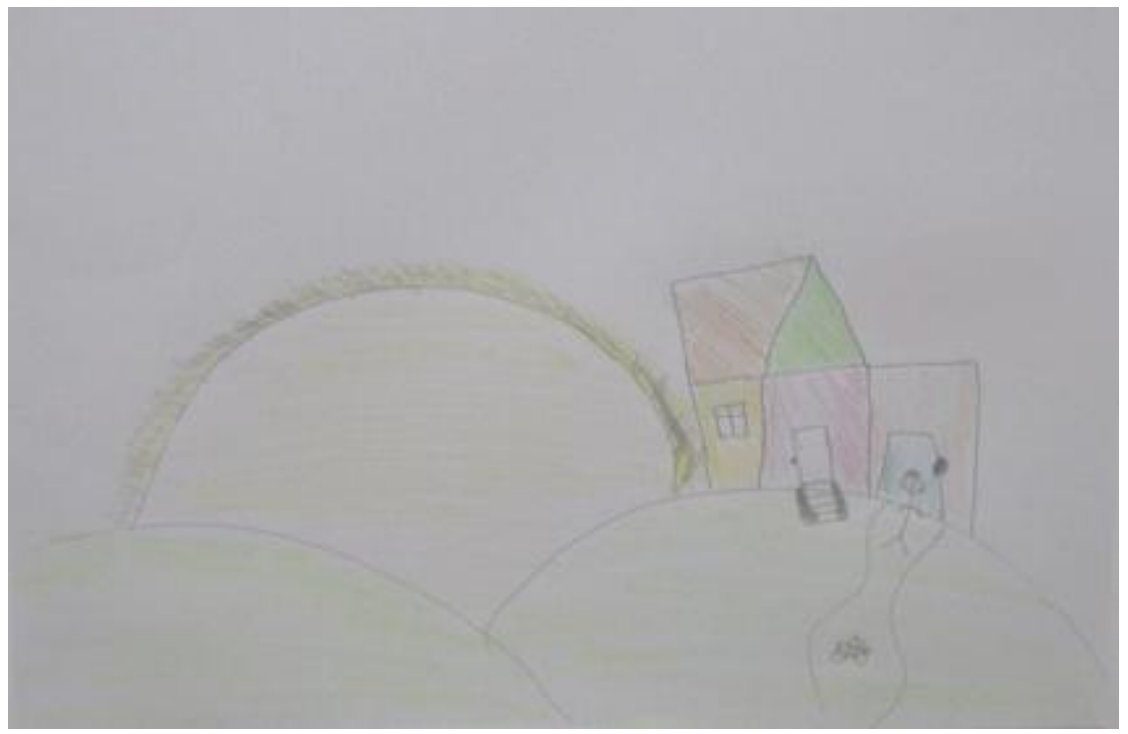

Figura 48 - Desenho 3 de Lucas no oitavo encontro. 


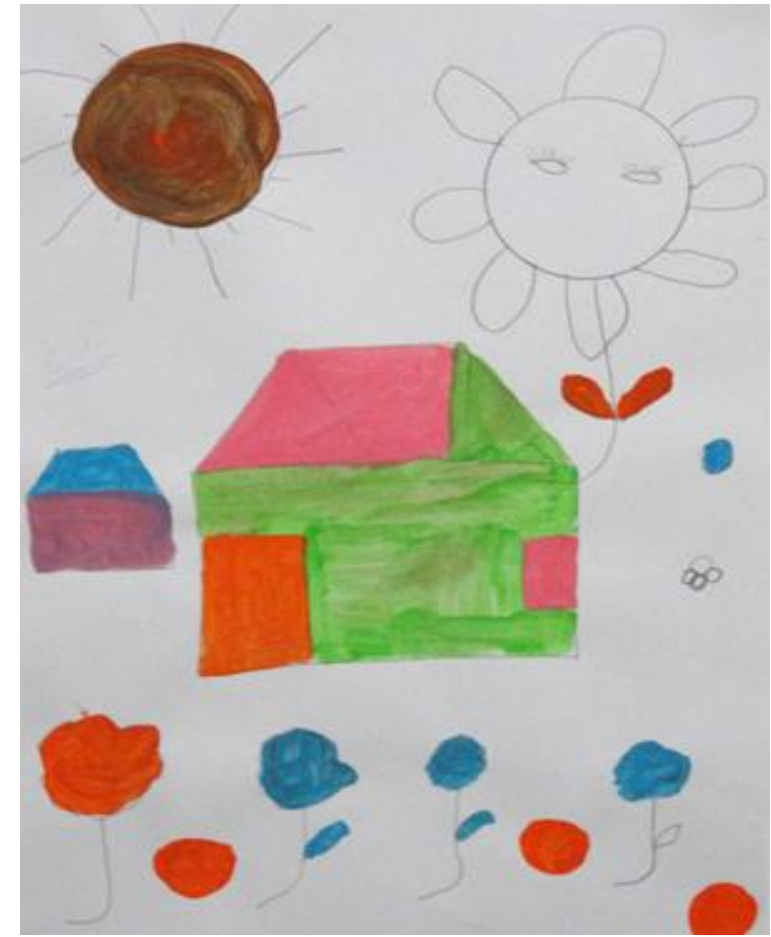

Figura 49 - Desenho de Cecília no oitavo encontro.

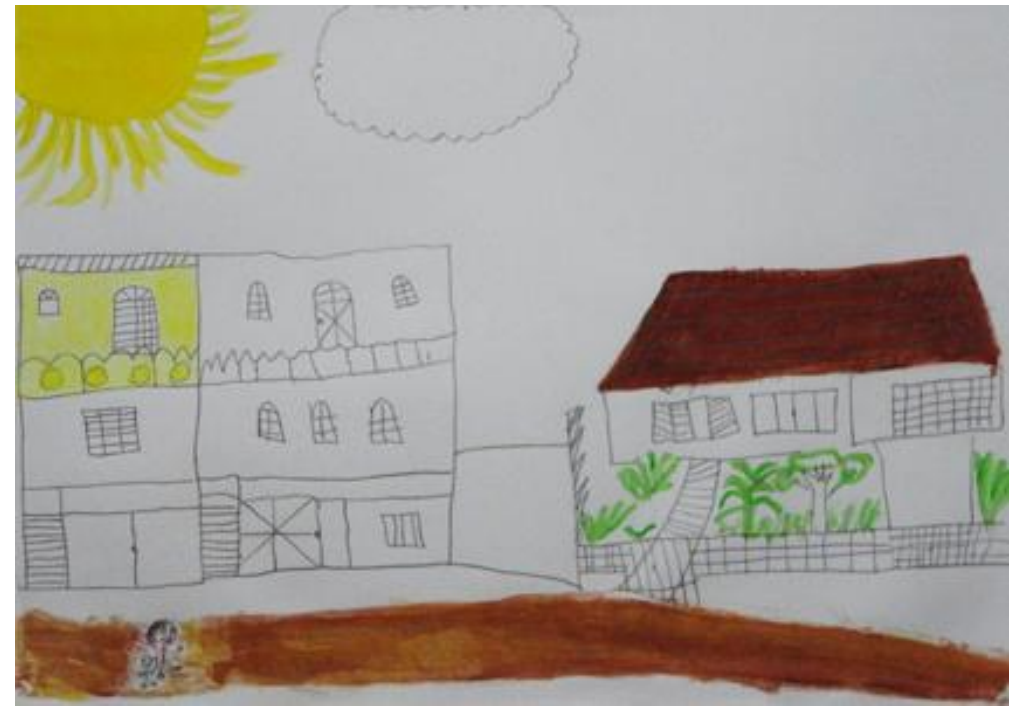

Figura 50 - Desenho de Paula no oitavo encontro. Ao lado esquerdo vemos Paula e seu filho, saindo de casa e caminhando rumo ao abrigo. 


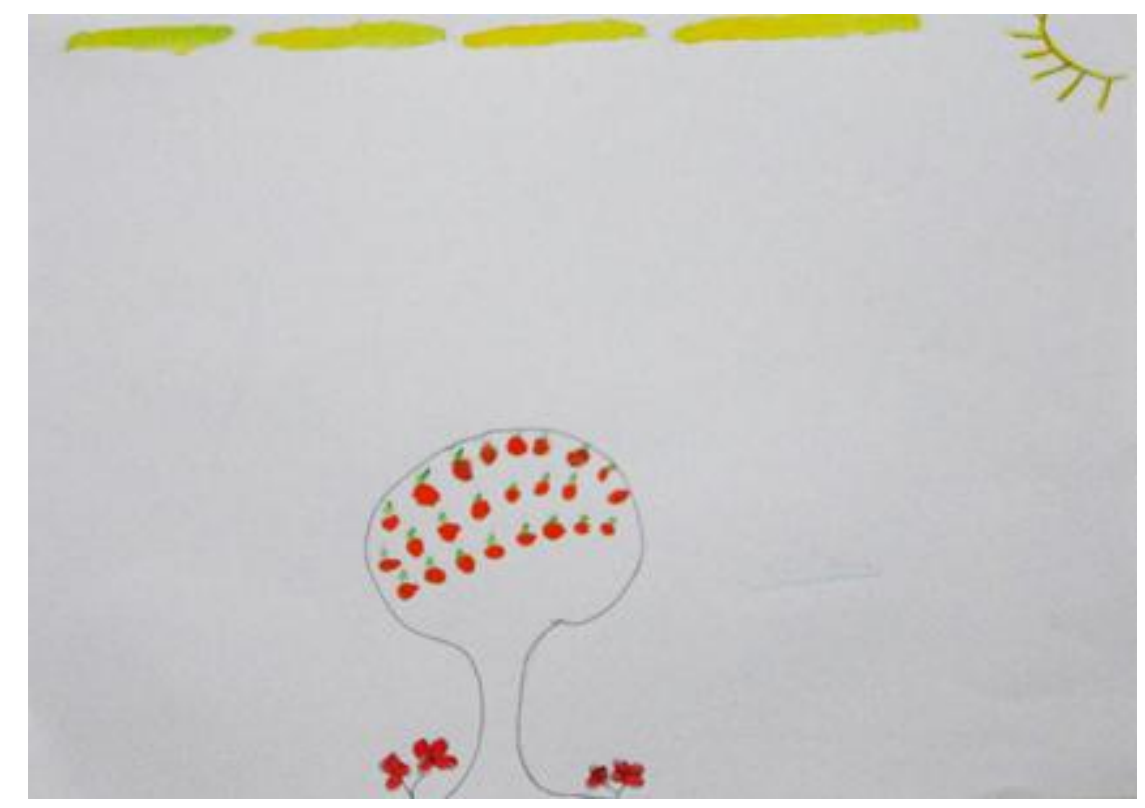

Figura 51 - Desenho de Meire no oitavo encontro.

\section{NONO ENCONTRO}

"O carro que nos leva aos nossos sonhos".

Não pude ir nesta semana e vou na seguinte. Maiara já voltou das férias na casa do irmão e, coincidentemente, Gabriela volta a se retrair. Passa a ficar muitíssimo calada e seus desenhos retornam a temas como as nuvens e flores. Fica muito tempo olhando as trocas entre Maiara e Josi. Parece estar enciumada.

Além disto, nesta oficina o irmão de Josi estava presente pela primeira vez. Ele, Josi e Maiara se conhecem desde o outro abrigo e demonstram um forte entrosamento. Guilherme está presente e tem um comportamento extremamente inconveniente: o tempo todo faz comentários que irritam os outros participantes. Talvez também incomodado pela cumplicidade entre o trio. Procura sempre se opor quando tentamos adivinhar o que está desenhando. Desenha uma casa e diz que é o local onde morará quando sair do abrigo numa cidade do interior de São Paulo. 
Anteriormente, havia desenhado um carro, então pergunto se será aquele carro que o levará para casa e ele diz que pode ser. Percebo que o carro é o que viabiliza os sonhos, o mais almejado. Então pergunto aos outros membros do grupo: "Se este carro pudesse levar vocês para onde quisessem, onde seria?" Josi conta que gostaria de ir para a Espanha e o irmão, para Barcelona ver jogos de futebol. Maiara diz que não sabe e Gabriela conta que queria ir para o "norte" (nordeste), onde tem parentes.

Comento que a flor de Gabriela não tem caule e as outras meninas dizem parecer cair do céu. Gabriela não comenta nada. Termina seu desenho muito rapidamente e passa o resto do tempo muito atenta à conversa de Josi, seu irmão e Maiara. Josi desenha várias bolas. Digo que me lembram confetes coloridos. Ela conta que está desenhando aquilo, pois está feliz, uma vez que as aulas começaram. E eu acrescento: "E também porque Maiara voltou..." Ela ri, um pouco sem graça e brinca que nem sentiu tanta falta assim da amiga.

Após os comentários, Maiara e Josi me ajudam a tirar os desenhos da parede. Ambas se interessam pelos desenhos que fizeram antes. No início desta oficina, disse que restavam três mais. Eles sempre souberam que no total, seriam 12 oficinas expressivas, mas o meu lembrete trouxe à tona a questão a despedida. Pergunto se gostariam de retomar os outros desenhos no último dia e elas gostam da ideia. Perguntam o que eu farei com os desenhos. Maiara diz que gostaria de ficar com o primeiro que fez. Digo que, na última oficina, levarei todos os desenhos, se quiserem ficar com algum estão autorizados e aqueles que, eventualmente restarem, eu guardarei com muito cuidado. 


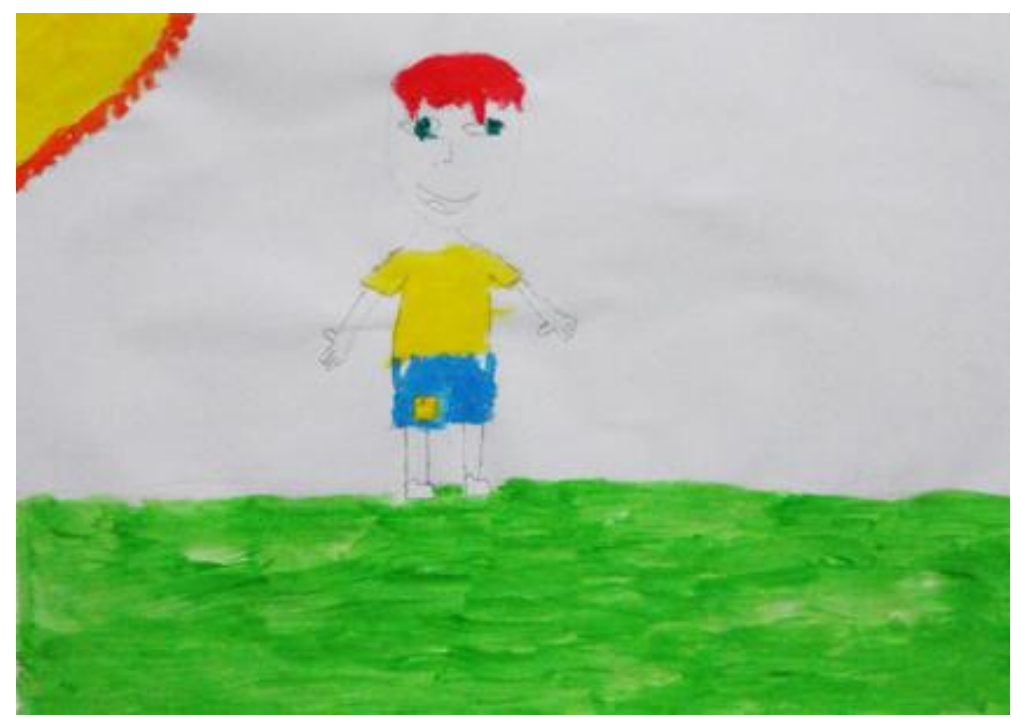

Figura 52 - Desenho de Kevin, irmão de Josi, no nono encontro.

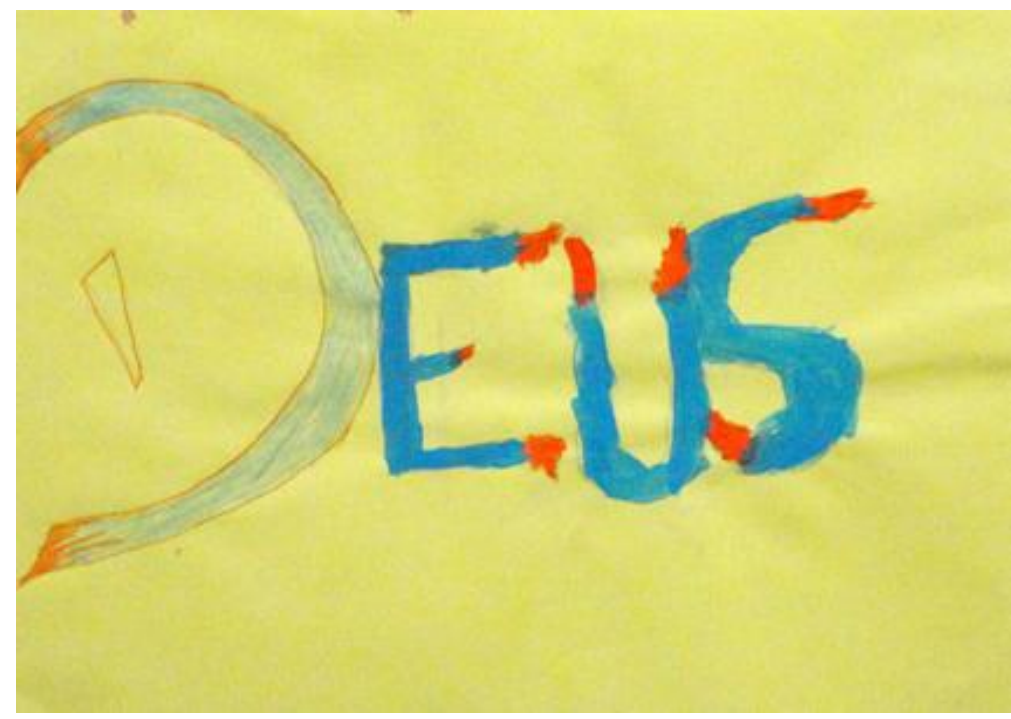

Figura 53 - Desenho de Maiara no nono encontro. 


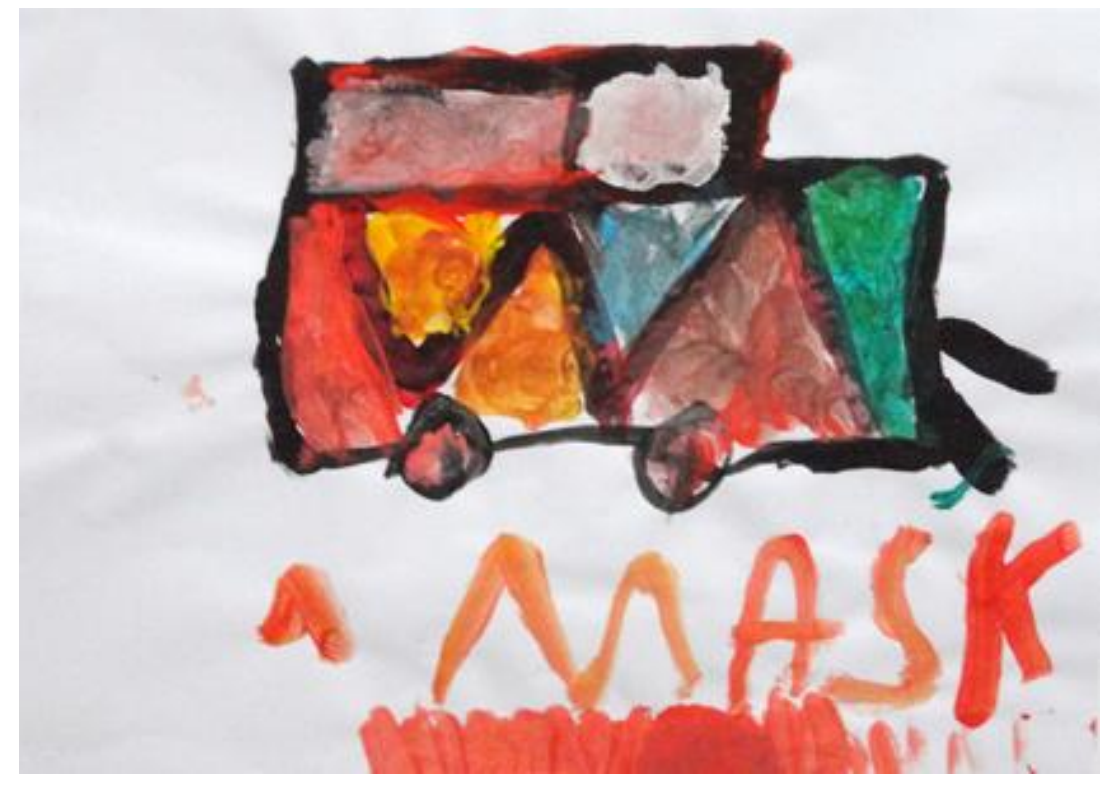

Figura 54 - Desenho 1 de Guilherme no nono encontro.

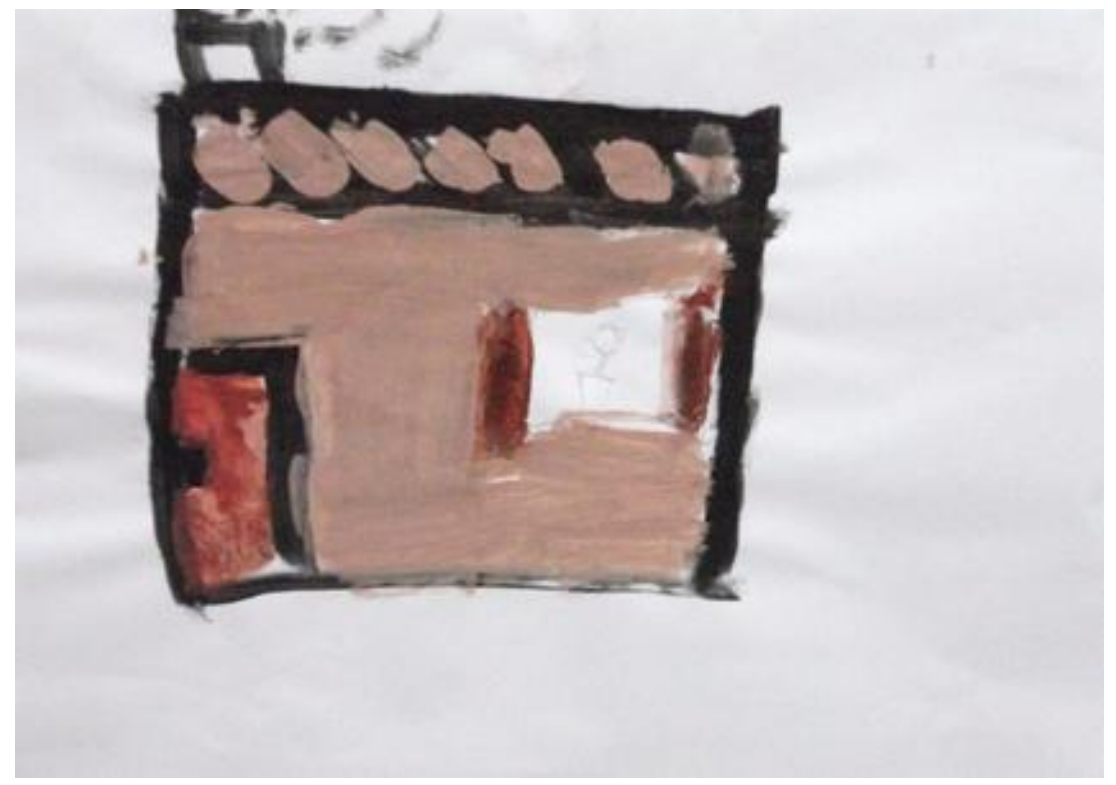

Figura 55 - Desenho 2 de Guilherme no nono encontro. 


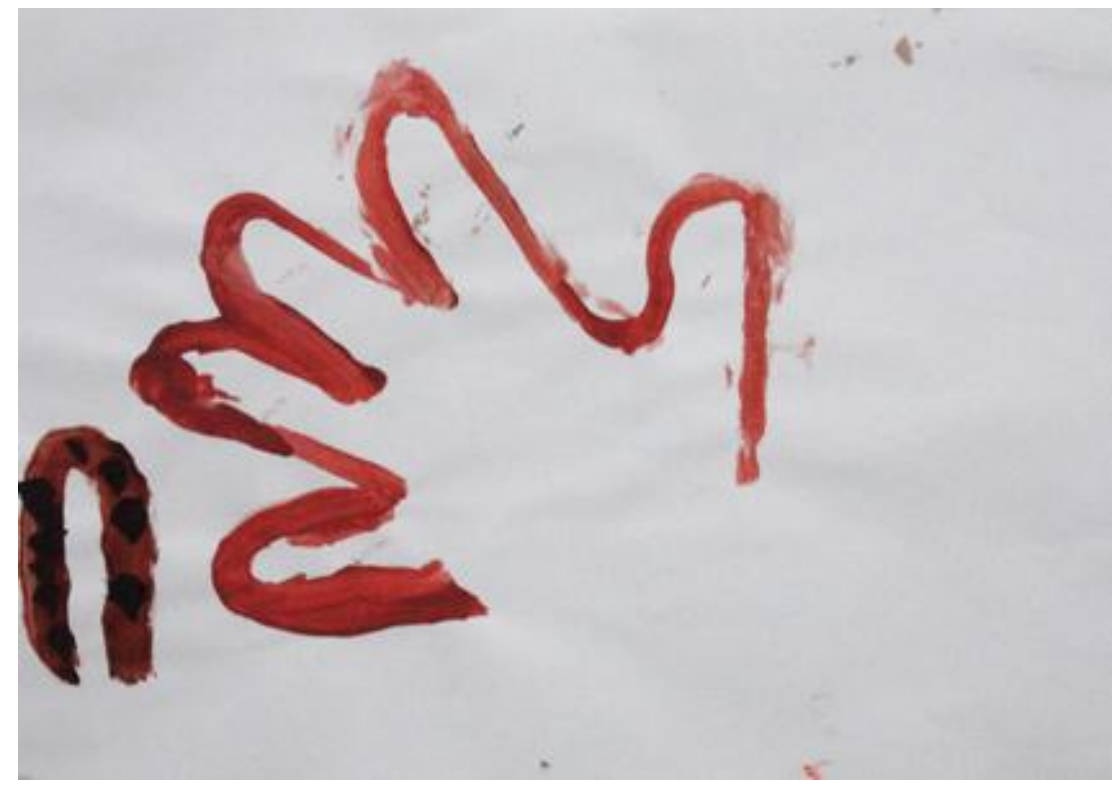

Figura 56 - Desenho 3 de Guilherme no nono encontro.

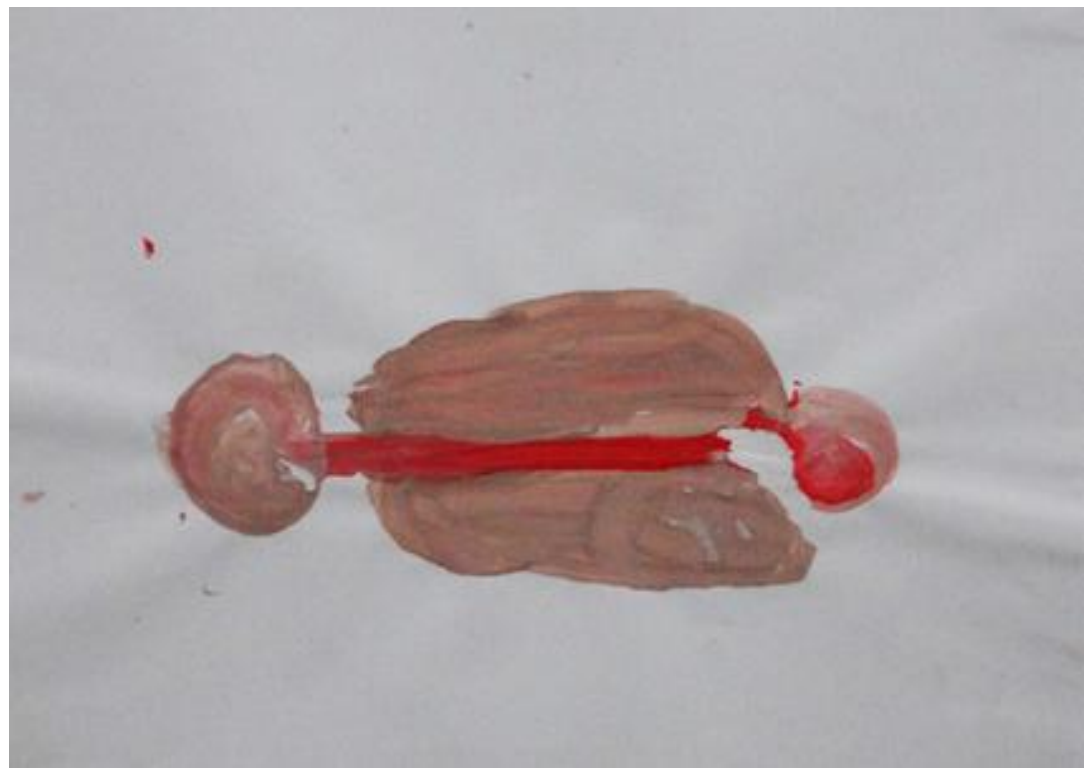

Figura 57 - Desenho 4 de Guilherme no nono encontro. 


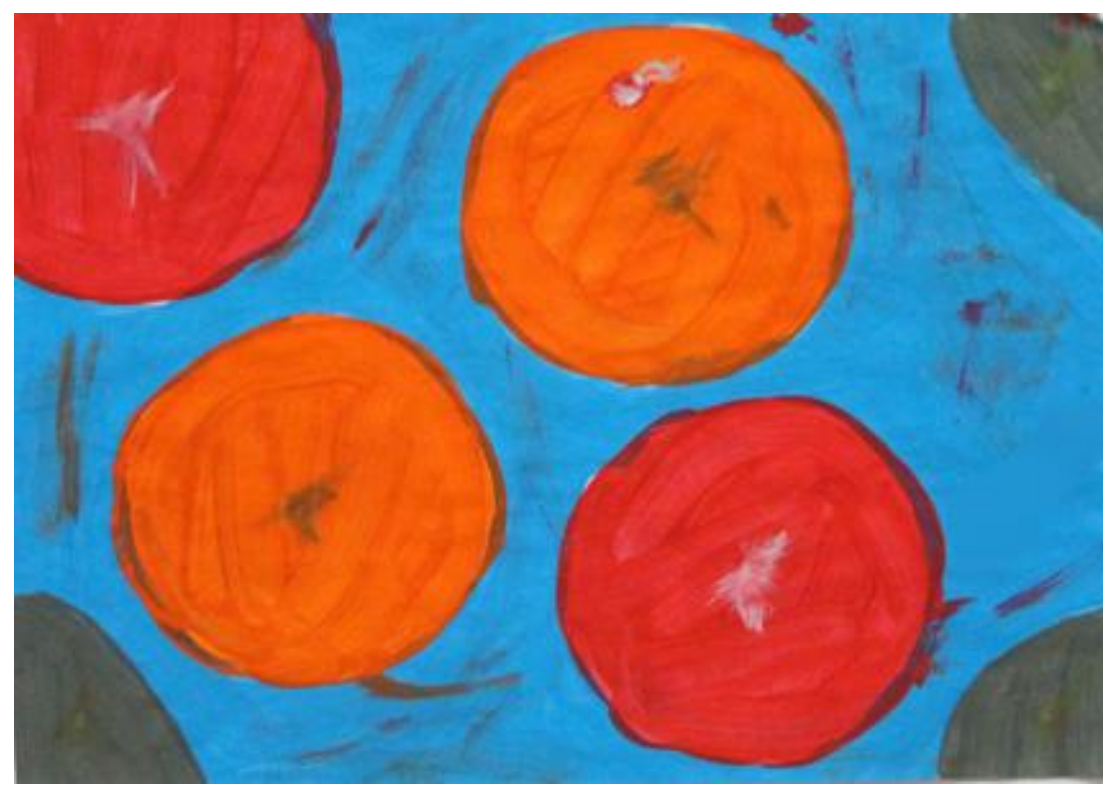

Figura 58 - Desenho de Josi no nono encontro.

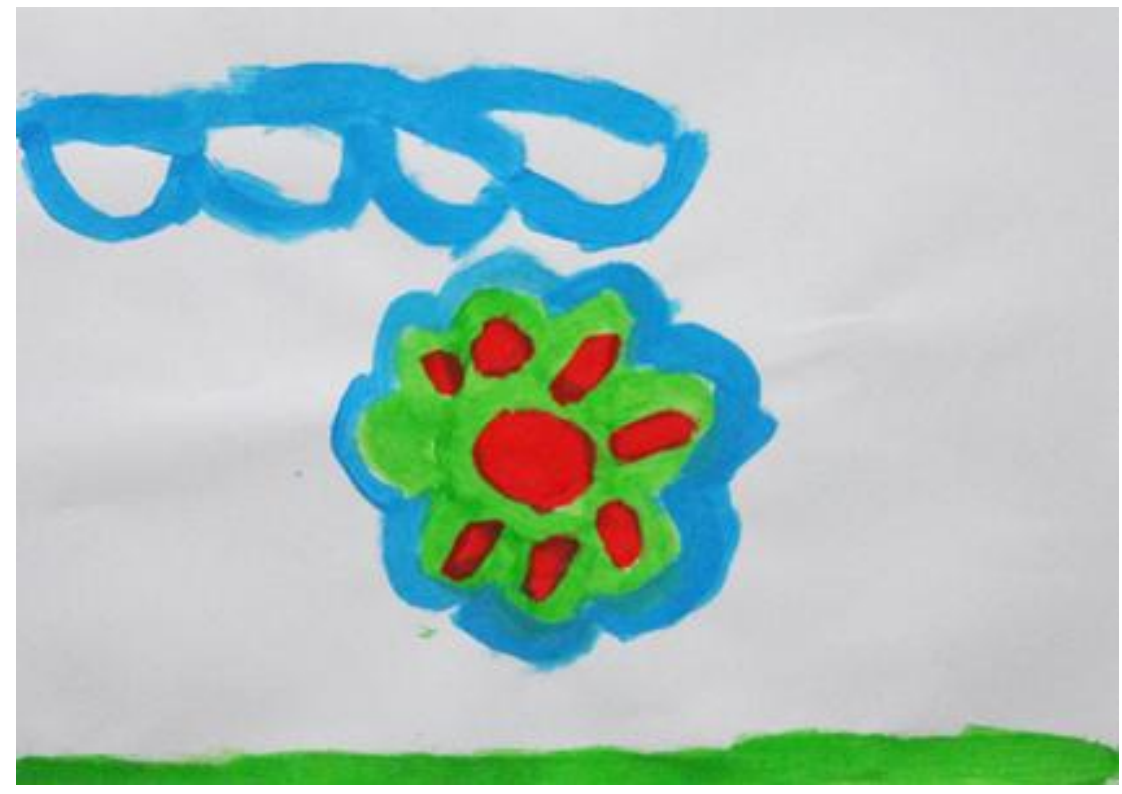

Figura 59 - Desenho de Gabriela no nono encontro. 


\section{DÉCIMO ENCONTRO}

"Um mau humor diferente."

Com o início do ano letivo, a partir desta oficina, o setting ficou bastante comprometido. Neste dia, assim que chego, sou avisada de que haverá reposição da aula de informática. Como cheguei um pouco mais cedo e diante deste imprevisto, decido começar a oficina mais cedo de modo que a aula de informática não comprometa tanto o tempo da minha atividade. Cerca de meia hora após o início, chega a professora de informática acompanhada pelo filho e pergunta se ele poderia participar.

Gabriela se recusa terminantemente a participar. Mal quis que eu me aproximasse para convidá-la, ao me ver já disse logo que não queria. Em determinado momento, cruza o refeitório na presença da assistente social e ambas ficam na sala de informática de portas fechadas.

Josi está muito falante e faz seu desenho muito rapidamente. Contou-me que estava fazendo um curso profissionalizante. Percebo que ela e Maiara não estão se falando diretamente, o que chama muito atenção devido ao vínculo que possuem. Ela termina seu desenho e pego para ver. Está escrito: "mal humor". Digo que me surpreendi, pois ela não parecia de mau humor e acrescento que este "mau humor" parece muito diferente daquele vivido nas férias. Aos poucos vai contando que está de mau humor desde a noite anterior. Pergunto se algo aconteceu e ela diz que sim. Pergunto o que foi e ela aponta para Maiara e diz: "Pergunta para ela".

Maiara conta que quebrou a maquiagem de Josi e esta acrescenta que, além disto, Maiara guardou a sombra quebrada na gaveta e sujou tudo. Para Josi, a pior parte - e ela reitera isso diversas vezes - foi que Maira mentiu para ela não assumindo a culpa logo de cara e "não suporta mentira". Tento conciliar uma conversa entre as duas: Maiara explica que mentiu porque não queria que a amiga ficasse brava. A adolescente responde que "não morde" e que tenta ser amiga de Maiara e Gabriela, mas elas só mentem. Gabriela também estragou algo de Josi e brigaram por causa disso. 
Josi fala muito mais do que Maiara que fica quieta a maior parte do tempo. Digo que as consequências são reversíveis. Mas Josi, magoada, diz que Maiara nem pediu desculpas. Com o meu incentivo, Maiara se desculpa, mas Josi invalida o pedido dizendo que não foi espontâneo.

A professora de informática que estava ouvindo toda a conversa disse que, uma vez superado o mau humor, Josi poderia fazer outro desenho. No início a adolescente se recusa, mas logo volta atrás. Coloca tinta no meio da folha, dobra e o resultado é uma forma abstrata na qual o verde predomina. Josi associa muito seus sentimentos às cores. Quando está "mal humorada" usa tintas e papéis escuros. Então, diante da mistura de várias cores, Ihe pergunto o que predomina naquele desenho e ela diz que tem um pouco de tudo. Digo que não me parece "maus humores" (e digo isto não tanto pelo desenho, mas pela postura da garota que parece muito mais distendida). Ela sorri, aponta para o preto do desenho e diz que ainda tem "mau humor", mas menos do que no início.

Guilherme e o filho da professora de informática presenciam toda a conversa. Guilherme interrompe diversas vezes para fazer comentários provocativos e piadas de mau gosto. "Se fosse Josi, ia pegar uma espingarda de água e dar na cara de Maiara", por exemplo.

Guilherme faz um desenho todo colorido e comenta que quer sair logo do abrigo, mas depende do juiz. Na semana anterior conversei com a psicóloga do abrigo sobre isto e ela me contou que a mulher que cuidará de Guilherme está muito ansiosa para tê-lo perto dela. O menino está mais agitado do que o habitual hoje. Fala muito e expressa várias opiniões "do contra" e continua com algumas piadas de mau gosto. Devo lembrar a todo o momento que deve respeitar os demais integrantes. Faz piadas de conotação racista, sendo que eu e Maiara somos negras. A sensação é que fala porque quer chocar, como se já esperasse a reprimenda. Numa das folhas escreve: "Guilherme.menino mau" - como se fosse um site. Enquanto fala de seus desenhos, este comportamento fica evidente. Fala que desenhou "cocô".

O filho da professora de informática gosta muito de Guilherme e sentou-se ao seu lado. Dava risada dos comentários engraçados emitidos por Guilherme e este se 
mostrava muito gentil com o amigo the mostrando os materiais. Guilherme aguarda ansioso o momento de comentar seus desenhos. É neste momento que todos estão com a atenção voltada para ele e pode dar vazão aos seus comentários sobre fezes.

Roberto não participa, dizendo-se muito atarefado, mas em determinado momento manda uma educadora me dar o recado de que, nenhuma cuidadora está autorizada a participar apenas ele.

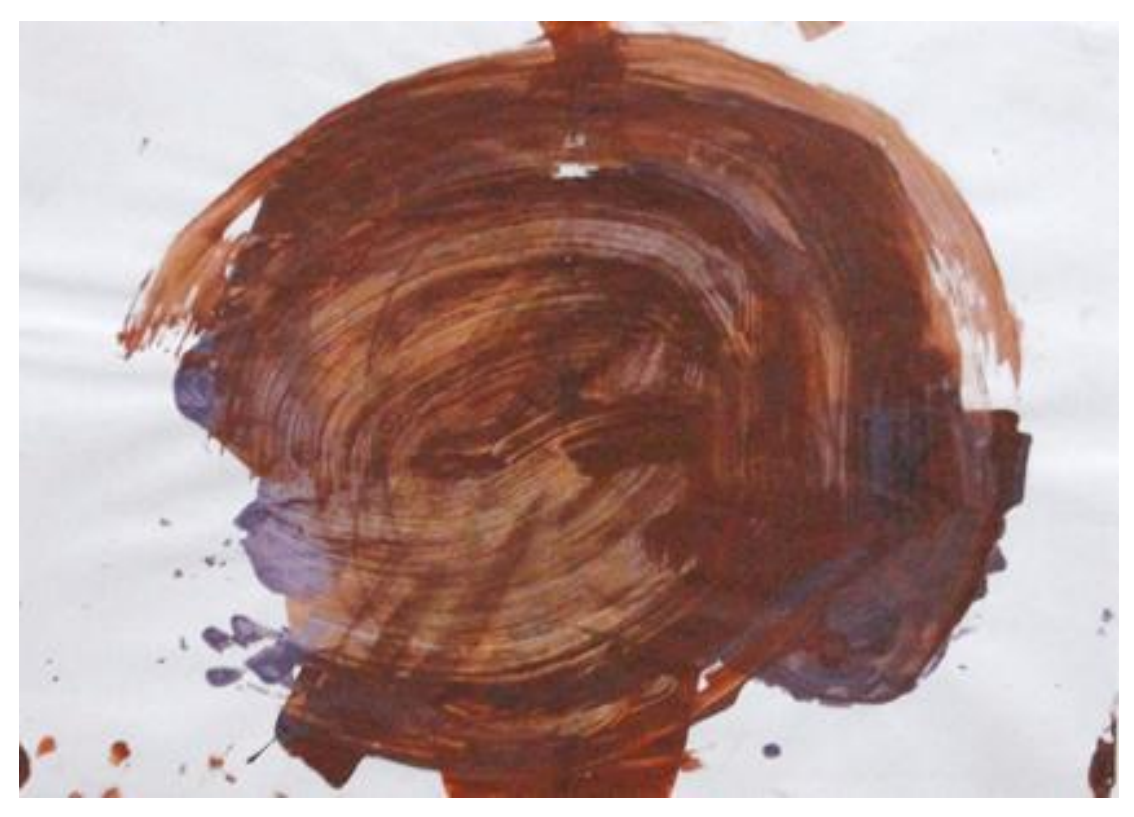

Figura 60 - Desenho 1 de Guilherme no décimo encontro. 


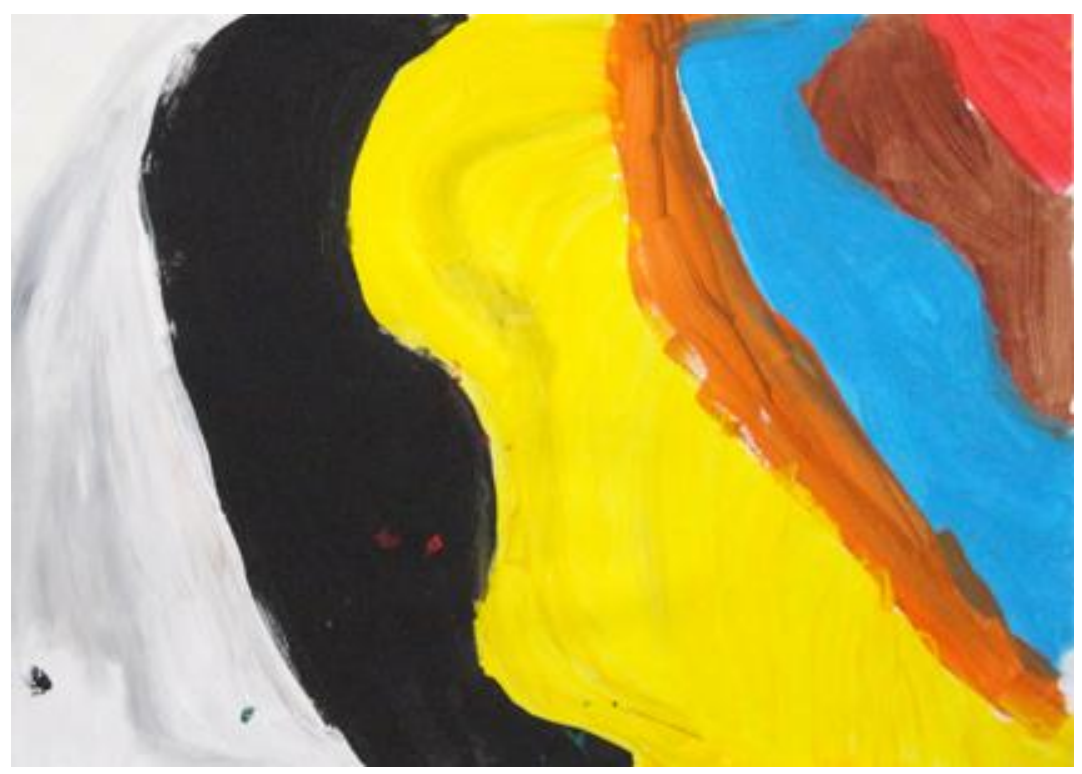

Figura 61 - Desenho 1 de Josi no décimo encontro.

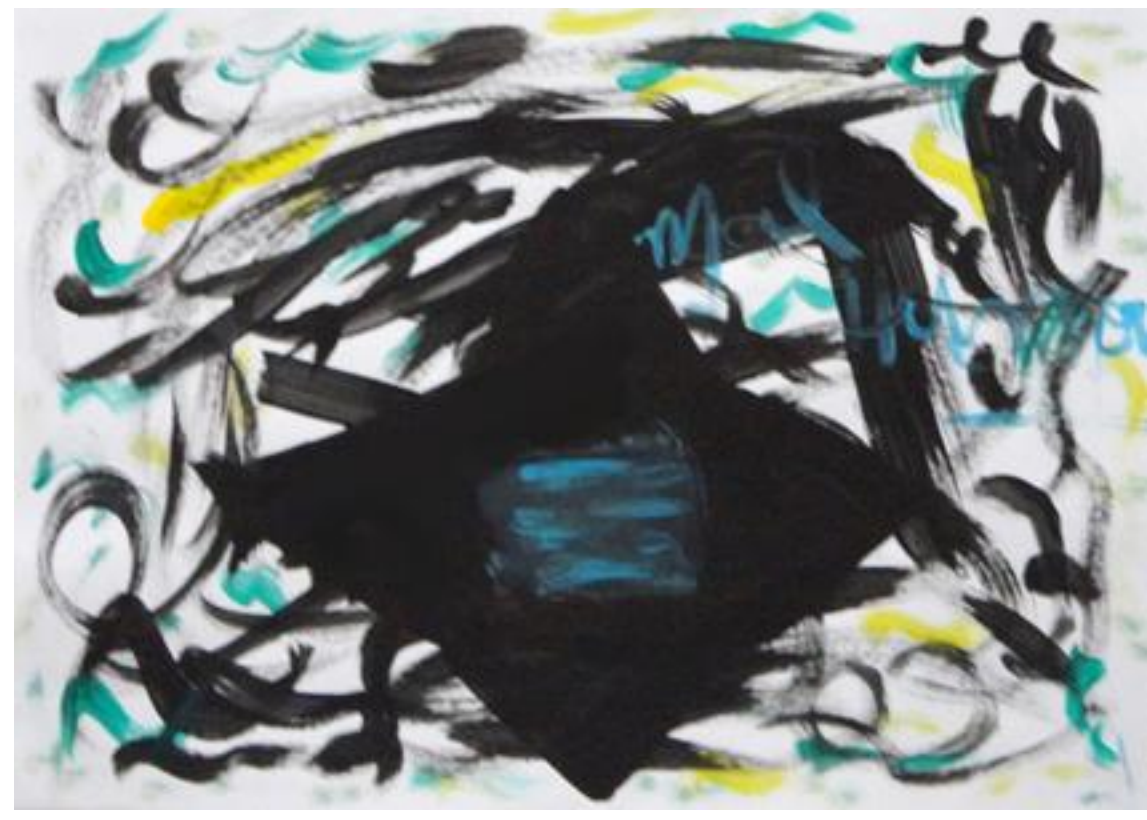

Figura 62 - Desenho 2 de Josi no décimo encontro. No lado esquerdo está escrito: "'Mal' humor". 


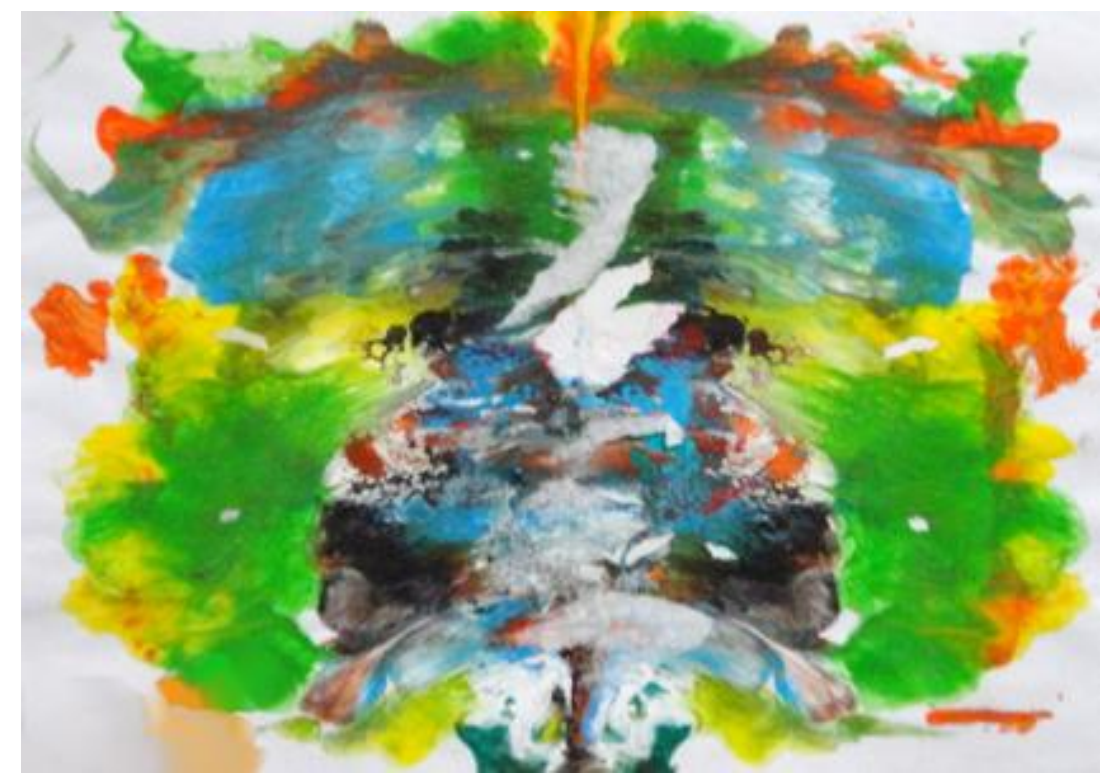

Figura 63 - Desenho de 3 de Josi no décimo encontro.

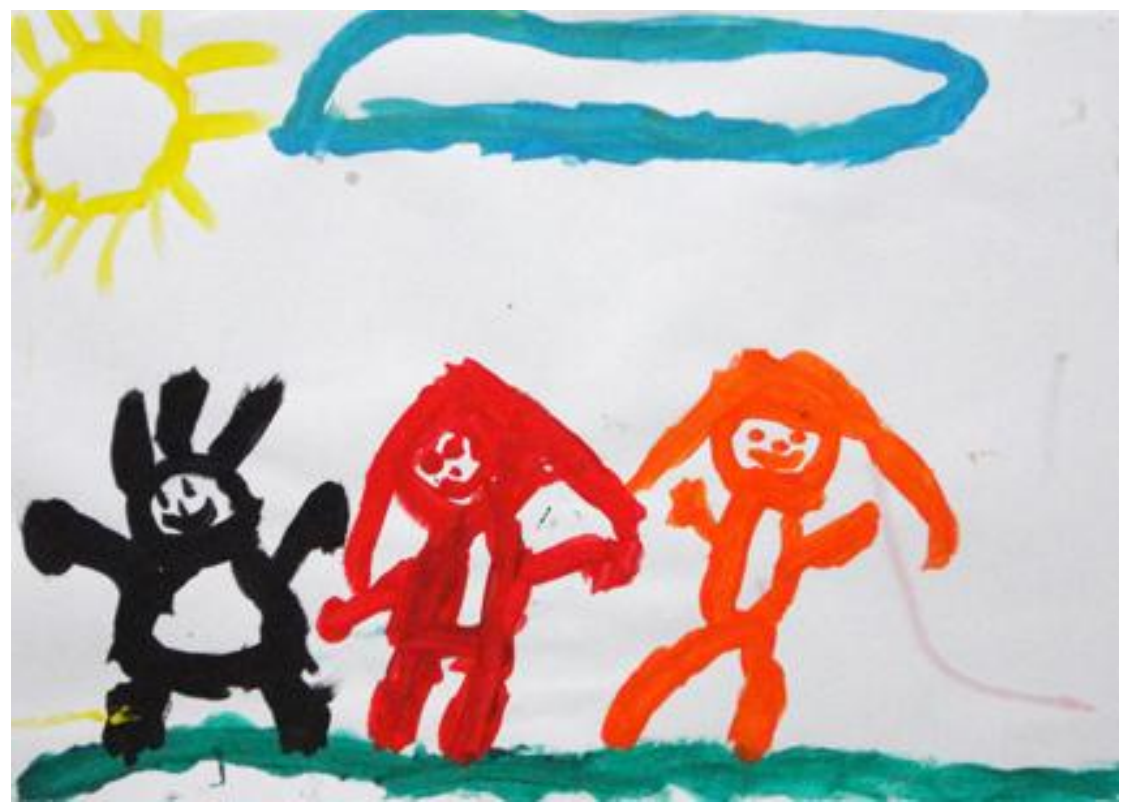

Figura 64 - Desenho do filho da professora de informática no décimo encontro. 


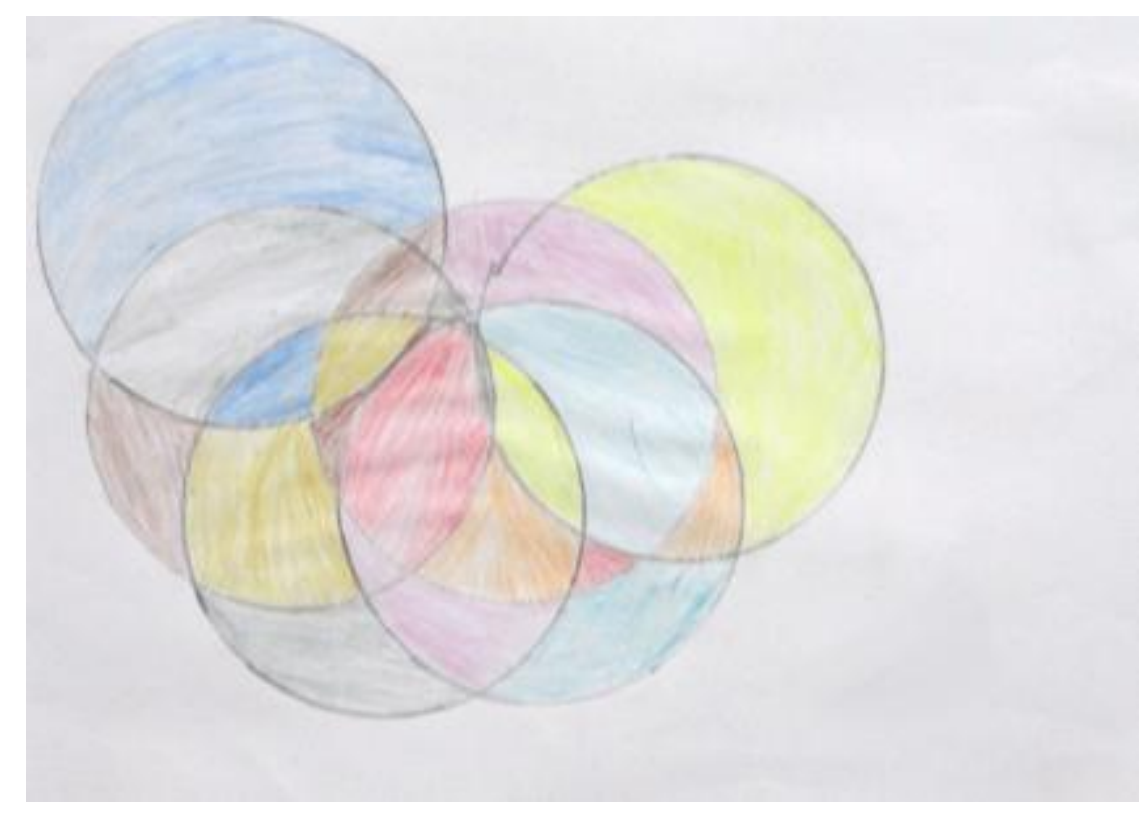

Figura 65 - Desenho de Maiara no décimo encontro.

\section{DÉCIMO PRIMEIRO ENCONTRO}

"Josi confia".

A oficina começa antes da hora, pois as crianças e adolescentes da casa sairão para fazer exame médico para a aula de natação. Gabriela é a primeira a chegar. Está carinhosa, me abraça. Digo que senti a falta dela na última oficina e pergunto se irá participar. Ela diz que sim. Guilherme está muito ansioso para que eu comece antes dele sair para o exame médico.

Logo no início, aviso que este é o penúltimo encontro e que no próximo retomaremos todos os outros desenhos feitos por eles. Então, faço a proposta do desenho coletivo. Aparentemente, todos parecem aceitar bem, até que Josi propõe que cada um desenhe em um quarto do papel (eram cinco participantes). Então a conversa se encaminhou sobre quem ficaria de fora. Havia um menino que nunca 
participara das oficinas: João ${ }^{30}$. Josi pega a cartolina, dobra em quatro partes e delimita o espaço de cada um. Guilherme fica visivelmente decepcionado com a restrição e tenta convencer a adolescente para que todos façam um desenho só em toda a extensão da folha, mas Josi se recusa.

Em seguida, Josi e Guilherme começam a desenhar e percebo que Maiara e Gabriela não estão participando e afirmam que não vão desenhar. Guilherme barganha a parte do papel de Maiara, que ficou ao lado rabiscando um pedaço de jornal. Sento ao lado delas, insisto para que participem, mas diante da recusa desanimada das duas, digo que, se quiserem, podem desenhar em outras folhas. Elas não se interessam. Gabriela ficou com a cabeça baixa sobre os braços o tempo todo, até que simplesmente se levantou e foi embora sem dizer nada. João ficou com o pedaço de Gabriela e fez um coração com o nome de Maiara dentro. Apesar de cada um ter feito um desenho em um quarto do papel, todos desenharam corações. Maiara fica o tempo todo na mesa, quieta rabiscando o jornal. Quando João ou Guilherme fazem alguma brincadeira, ela ri, mas não fala diretamente com Josi.

Sinto que aconteceu algo entre as meninas. Pergunto, insisto e Maiara responde que Josi ainda não está falando com ela. Josi reafirma o quanto ficou chateada com a mentira e o quanto está cansada, mas, diferente da oficina anterior, Josi parece não querer falar muito no assunto. João e Guilherme começam a falar das meninas da casa e sobre relacionamento amoroso entre eles.

Todos saem para fazer o exame médico e fico com Josi, que não se interessou pelas aulas de natação. Então, aproveitando que estamos sozinhas, pergunto novamente sobre o conflito com Maiara. Josi começa dizendo o quanto fica incomodada com a falta de espaço e o desrespeito com suas coisas, pois as meninas vivem pegando o que é dela e estragam. Conta que na manhã de hoje brigou com Gabriela que pegou um brinco seu e perdeu.

\footnotetext{
30 João é muito amigo de Kevin, irmão de Josi. Tem mais ou menos 14 anos, como o amigo. Estuda no período da tarde, o que impossibilitou sua participação desde o início. Durante as férias, quando pôde participar, não quis mesmo convidado, a não ser neste encontro. João fora retratado por Maiara no seu primeiro desenho do primeiro encontro. É ele que está com Kevin jogando bola no quanto esquerdo da folha.
} 
Fala muito sobre o quanto se sente cobrada pelos educadores em relação à sua saída do abrigo e que se sente exigida a ter um comportamento exemplar: tem sempre que ajudar nas tarefas da cozinha, limpar a casa, ser compreensiva e ajudar os outros. Sente-se mais autêntica na escola, porque diz que lá não é julgada e ninguém vai dedurar o que vier a fazer. Ressente-se por não ter atenção da diretora do abrigo que está sempre ocupada. Nem em Maiara confia mais. Usa uma metáfora sobre um cristal que se quebrou e que, mesmo colado, nunca mais será o mesmo.

Fala do quanto as pessoas não a conhecem, pois pensam que ela é feliz só porque fica sorrindo, mas ninguém sabe o que vai dentro dela. Reclama muito de não poder sair para visitar amigos ou ir a festas. Sente-se numa prisão.

Fez terapia por dois anos porque era obrigada. Não confiava na terapeuta que contava tudo para a diretora do outro abrigo. Insisto que é bom ter alguém para conversar. Ela nega esta necessidade e diz que gosta de conversar consigo mesma na frente do espelho e que conta seus segredos para si mesma. Nem seu irmão lhe parece uma pessoa em quem possa confiar. Relata uma briga feia que tiveram há algum tempo. Considera-o interesseiro, sempre pedindo bala e dinheiro.

Não pensa em desabrigar o irmão assim que sair, quer que ele esteja trabalhando e estudando, porque não vai sustentá-lo. Quando sair do abrigo, sua vida será diferente porque será livre e não vai nunca deixar seus próprios filhos num abrigo porque ela sabe a solidão de morar em um. Pergunto se ela conseguirá deixar o irmão tanto tempo num abrigo depois que sair, já que sabe a dor de morar num abrigo. Ela fica pensativa.

Ao final diz: "Até que é bom conversar com alguém".

Enquanto conversávamos, Josi preencheu toda a cartolina com flechas de duplo sentido. A relação entre o mundo externo e interno - seja do abrigo ou da própria adolescente - parece em questão. Com as flechas, Josi acabou integrando o desenho que ela mesma havia feito questão de compartimentar. 
Converso com Roberto rapidamente. Ele se desculpa pela ausência dizendo que tinha muito trabalho. Eu saliento que o próximo encontro será o último e a importância dele poder comparecer. Ele confirma a presença.

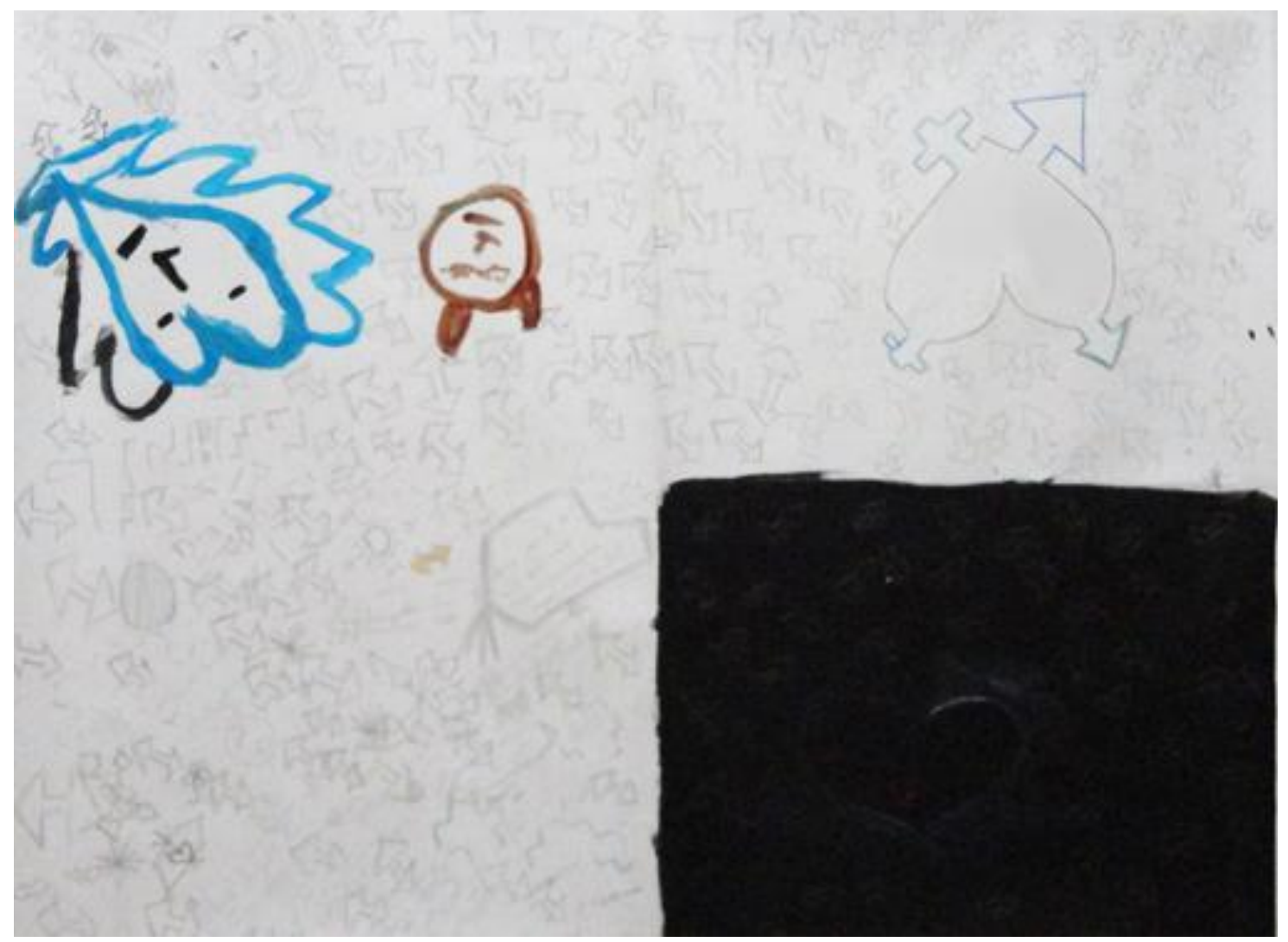

Figura 66 - Desenho coletivo no décimo primeiro encontro. 


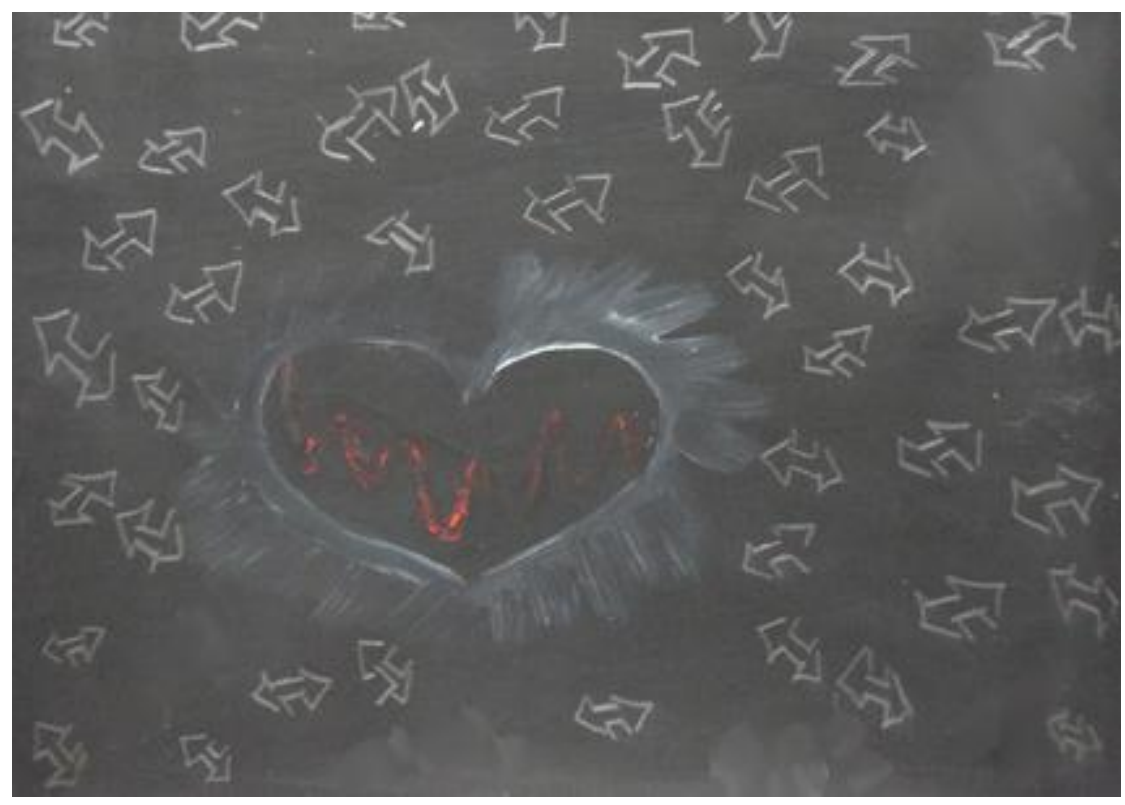

Figura 67 - Detalhe do desenho coletivo feito por Josi

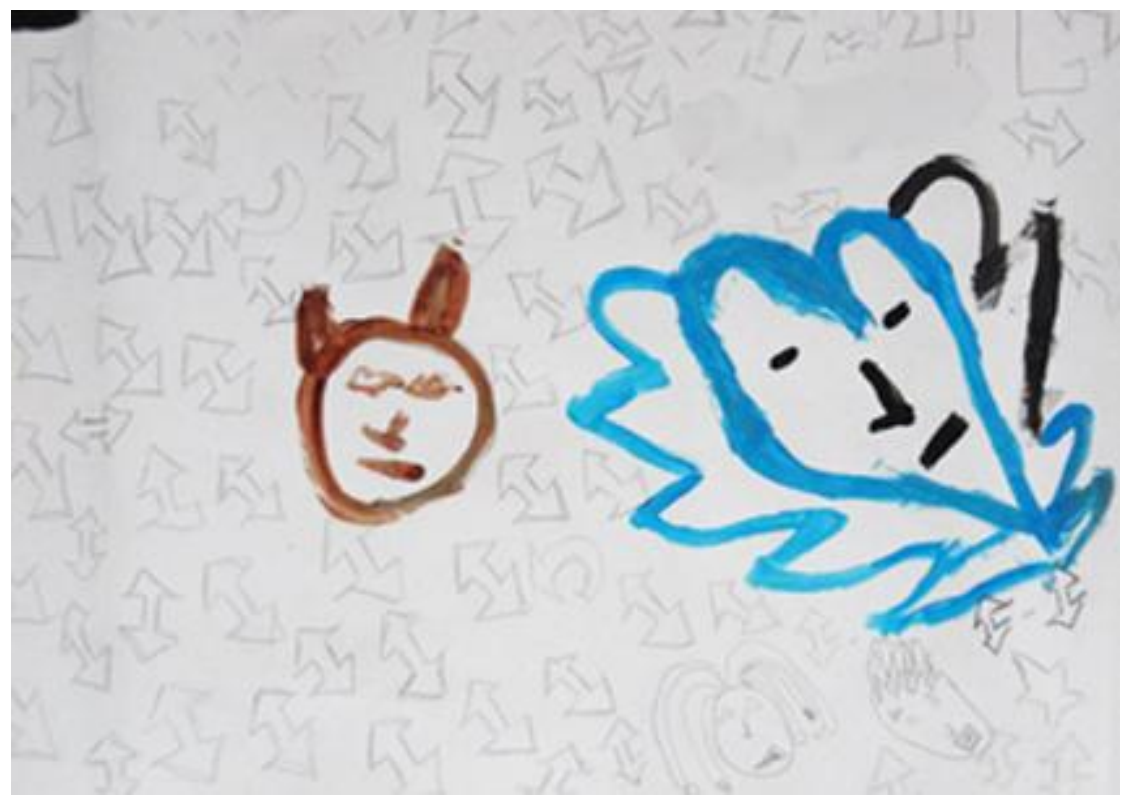

Figura 68 - Detalhe do desenho coletivo feito por Guilherme 


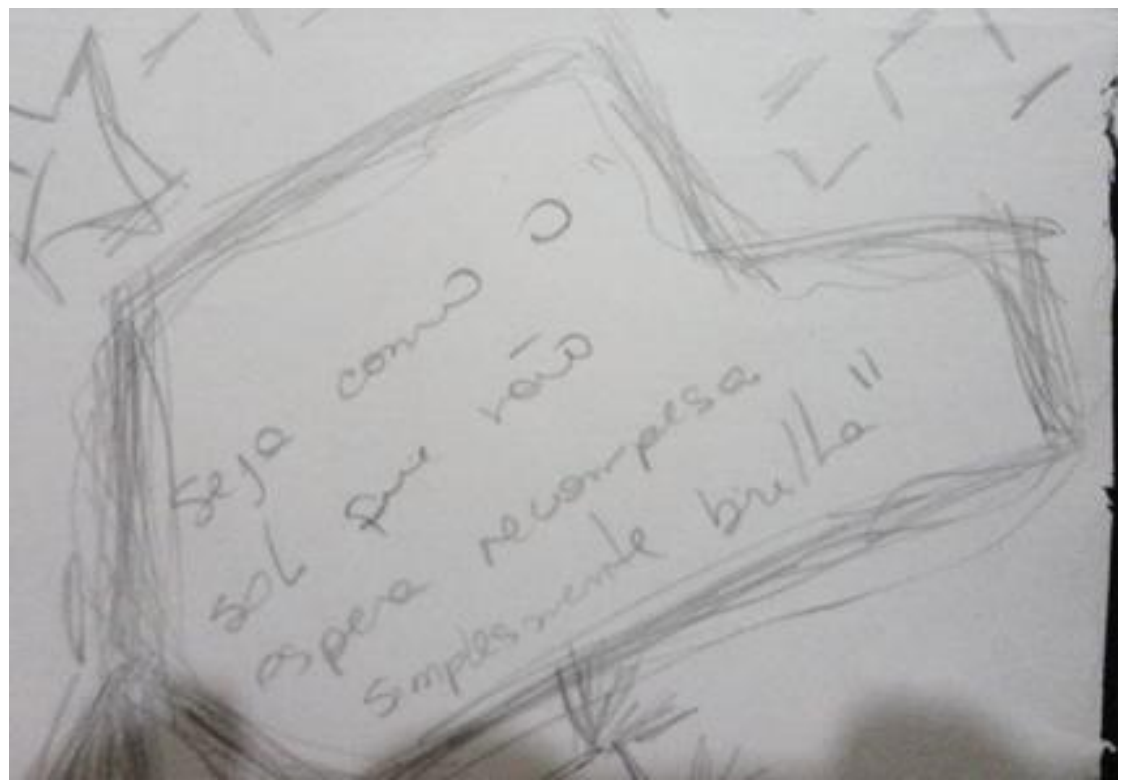

Figura 69 - Detalhe de escrito feito por Josi: "Seja como o sol que não espera recompensa simplesmente brilha"

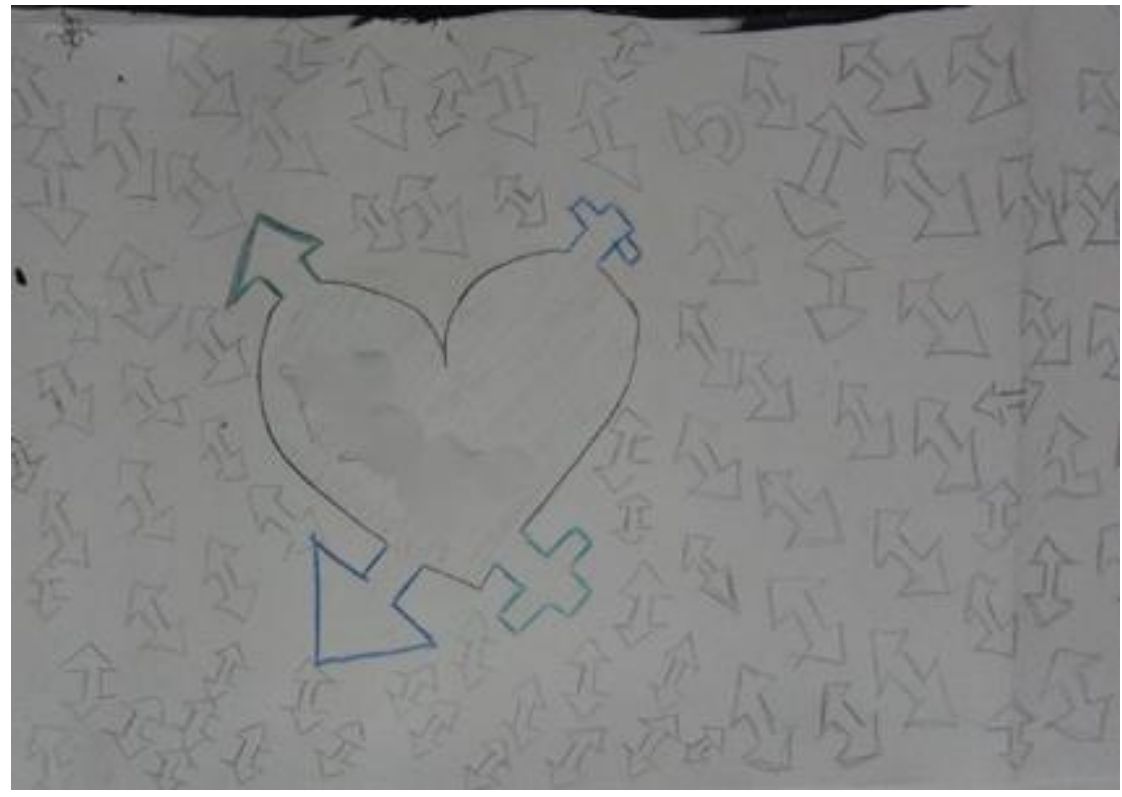

Figura 70 - Detalhe do desenho coletivo feito por João. Dentro do coração estava escrito o nome de Maiara. 


\title{
DÉCIMO SEGUNDO ENCONTRO
}

\author{
"Os pactos"
}

Josi me ajuda a colocar todos os desenhos na parede e enquanto isso, nós fazíamos uma retrospectiva. Comentou o quanto estava sentindo falta de Roberto que tirou toda a semana do carnaval de folga. Quando colocávamos na parede os desenhos da última oficina, Josi me perguntou se eu me lembrava do que havíamos conversado na última oficina. Digo que sim, mas ela diz que não se lembrava de nada.

Desta oficina participaram Josi, Maiara, Guilherme, Kevin (o irmão de Josi), Paula, Leandro ${ }^{31}$ e Mariana ${ }^{32}$. Gabriela tinha natação no horário da oficina, mas como estava chovendo, voltou mais cedo, porém não quis participar. Não se aproximou nem quando fui perguntar se queria ficar com algum de seus desenhos.

Novamente propus um desenho coletivo e depois um individual. Leandro e Mariana não conseguiram se sentir a vontade para desenhar na mesma folha do que todos os outros. Talvez por ser a primeira vez que participavam, talvez por serem novos no abrigo quando comparados aos outros. No desenho coletivo, pedi que fizessem algo sobre o que havia ficado para cada um após as oficinas.

Leandro é vítima de comentários pejorativos dos outros adolescentes e crianças por ter voz e comportamento efeminado. Ele, por sua vez, tenta encarar a todos com desdém, querendo mostrar que não se importa com as brincadeiras e comentários. Surgem diversas brincadeiras e comentários de cunho agressivo e revela o quanto as relações deles são permeadas pela discriminação seja porque é negro, pobre, não tão pobre, porque é novo no abrigo ou porque está lá há muitos anos. Mesmo reassegurando a regra de haver respeito no espaço das oficinas, os comentários cessam por um tempo e voltam em seguida. Mariana não era chamada pelo nome, mas por "menina". Insisto para que a chamem pelo nome e diziam que

\footnotetext{
${ }^{31}$ Leandro já fora citado no oitavo encontro. Este é o primeiro encontro em que participa efetivamente, já tendo sido convidado em momentos anteriores. Parece não estar muito entrosado com os outros adolescentes e crianças da casa. Sempre que o vi estava sozinho ou na companhia de educadores.

${ }^{32}$ Mariana ingressou no abrigo quando estávamos no nono encontro. Ficava no vitrô da cozinha observando a atividade, mas não tinha autorização para participar. No décimo encontro chego a convidá-la diretamente, ela fica animada, mas uma educadora me diz que Mariana não pode ir, pois seus pais estavam em reunião com a coordenadora e a menina não podia encontrar com eles. Tinha mais ou menos 12 anos e parecia ser mais próxima de Gabriela.
} 
não sabiam o nome dela, pois era nova. Mas ela estava lá há pelo menos um mês. Em seu desenho, Leandro escreve uma frase que tem ligação tudo isso que acontecia com ele. Escreve: "Era o brinquedo que todos gostavam de brincar, mas quando o brinquedo aprendeu a brincar ninguém gostou".

Mesmo com certa resistência, Josi, Guilherme e Maiara fizeram seus desenhos. Novamente Guilherme tenta propor um desenho só, mas novamente sua ideia é recusada. Josi foi a que se opôs diretamente afirmando que cada um deveria fazer seu próprio desenho, mas desta vez não dobrou a folha, delimitando os espaços. Guilherme faz diversas referências a fezes. Parece querer chocar como sempre, mas chega a dizer que sente dores quando vai ao banheiro. Josi diz que ele precisa beber mais água e se alimentar direito.

Josi e Maiara demoraram muito para terminar seus desenhos, fato que associei à dificuldade de lidar com o fim das oficinas. Até brinquei e disse que, se não terminassem os desenhos eu não conseguiria ir embora e teria que ficar para o jantar. Elas responderam com um "Eba!".

Nos desenhos individuais, Josi escreve a palavra "paz". Depois desenha quatro flores em outra folha. Pergunto se estas flores representam algo em especial, ao que ela responde que não. Então Ihe digo que fiquei com a sensação que cada uma das flores representaria ela, Maiara, Gabriela e Roberto (a formação inicial do grupo). Então Josi começa a nomear as flores: a preta seria Maiara que é negra, a amarela seria Gabriela, pois tem a pele branca. Porém ao fazer isto, parece perceber que ela e Roberto ficariam em cantos opostos, então muda: ela seria a amarela e Roberto a azul. Maiara não chegou a fazer um desenho individual. Mariana fez um sol enquanto Guilherme fez a bandeira do Japão e revela que acha as meninas mestiças muito bonitas.

Paula desenha o mundo nas mãos de Deus e isto levanta uma discussão sobre religião e os adolescentes começam a fazer diversos comentários para criticar os valores de Paula que é evangélica. Eles perguntam coisas do tipo: "Deus é branco ou preto?", "Deus é o Sol?" Paula tenta explicar, mas eles não estão verdadeiramente interessados nas explicações, mas provocam ainda mais, perguntando: "Deus é um velho com barba branca?", "Então Deus é uma luz..." 
Ao final, digo que podem escolher os desenhos que querem ficar, e acrescento que, aqueles que não quiserem ficar, guardarei com carinho. Pegam poucos e deixam comigo quase todos. Percebo que ficam felizes em deixar os desenhos comigo, principalmente Guilherme que escolheu um a um.

A despedida se dá tranquilamente, pois sabem que na semana seguinte voltarei para um conversa individual. Perguntam diversas vezes se haverá desenhos, ao que esclareço que não.

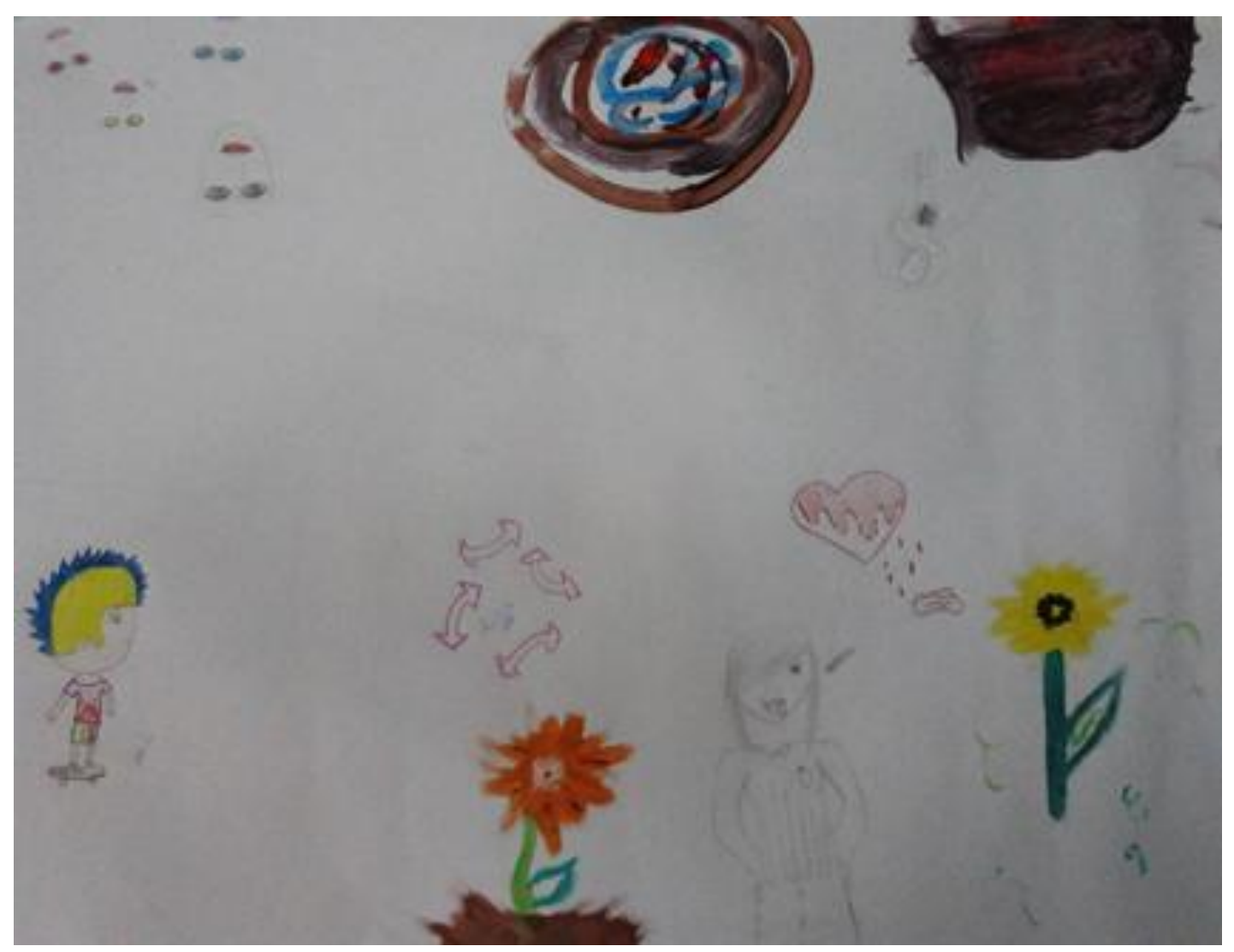

Figura 71 - Desenho coletivo no décimo segundo encontro. 


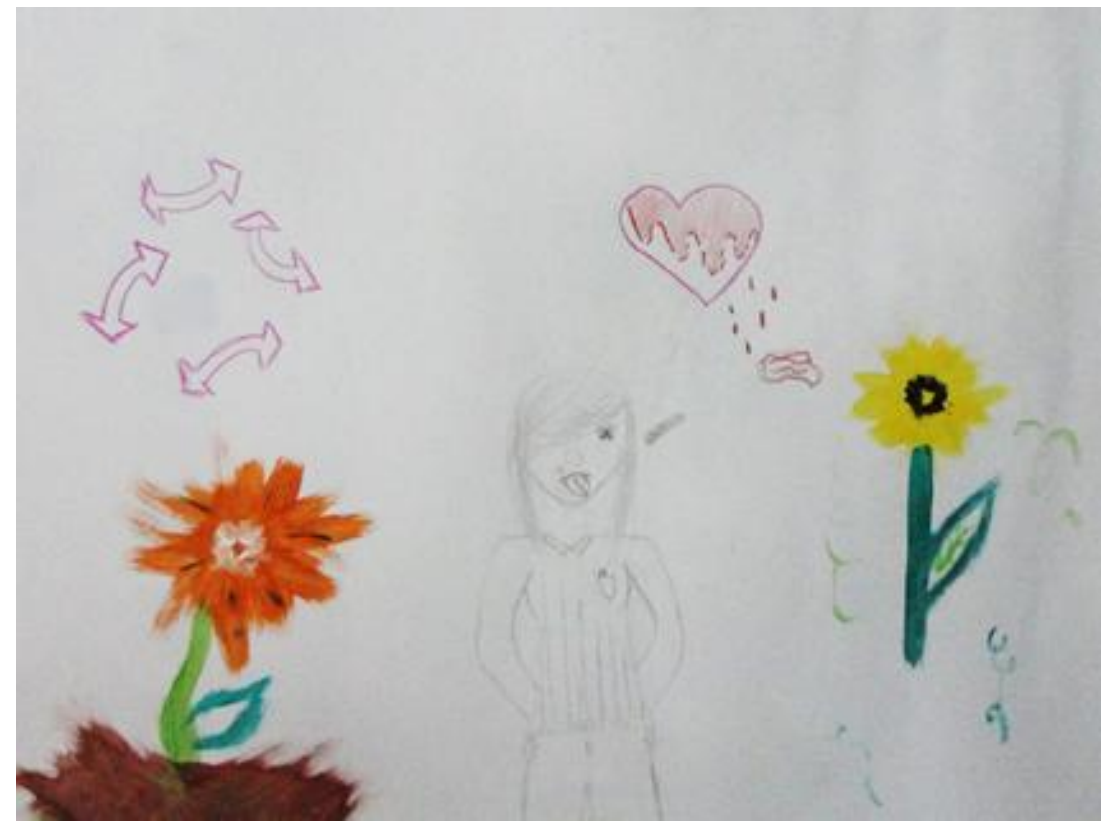

Figura 72 - Detalhe do desenho coletivo feito por Josi

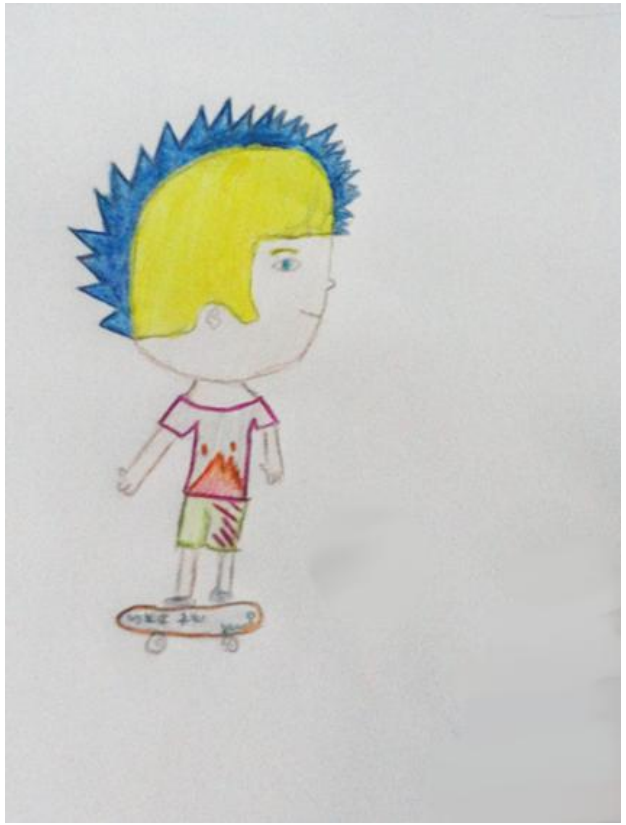

Figura 73 - Detalhe do desenho coletivo feito por Kevin 


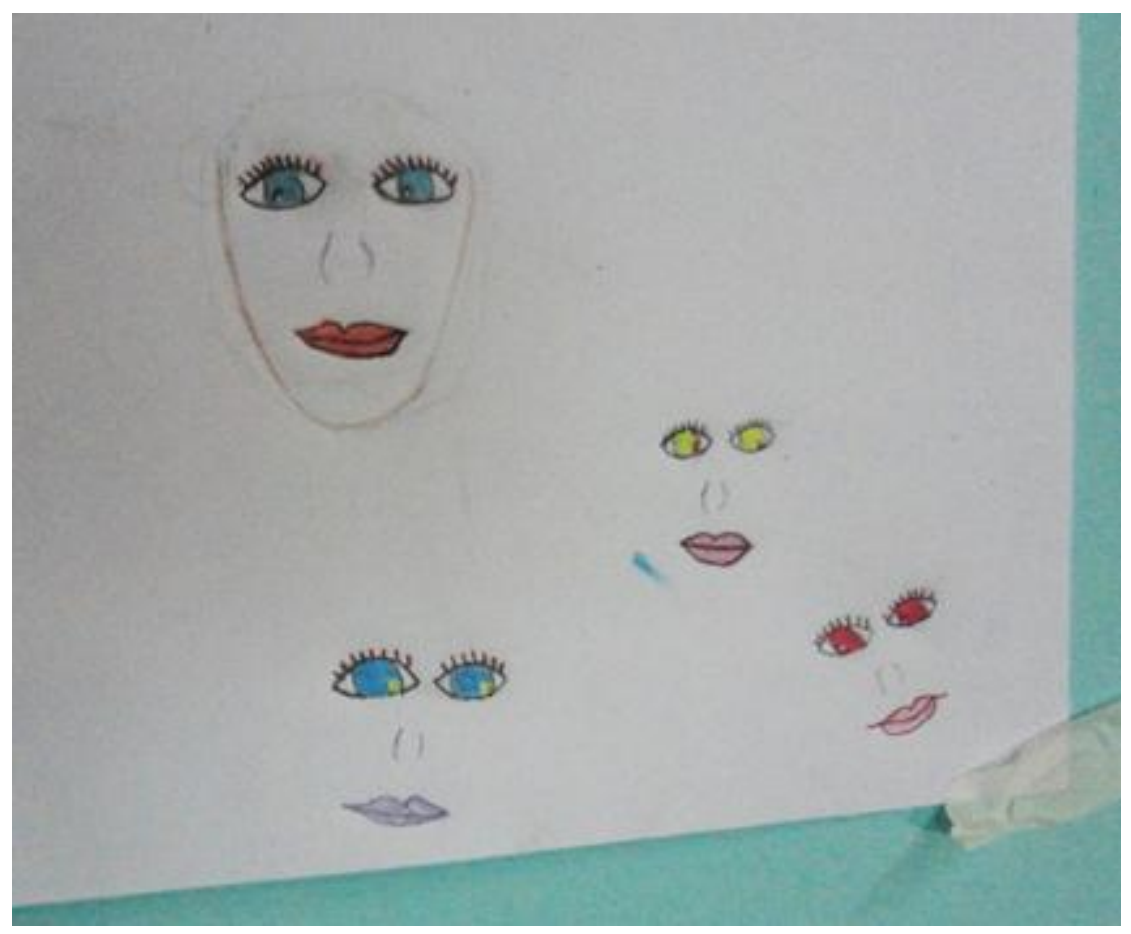

Figura 74 - Detalhe do desenho coletivo feito por Maiara.

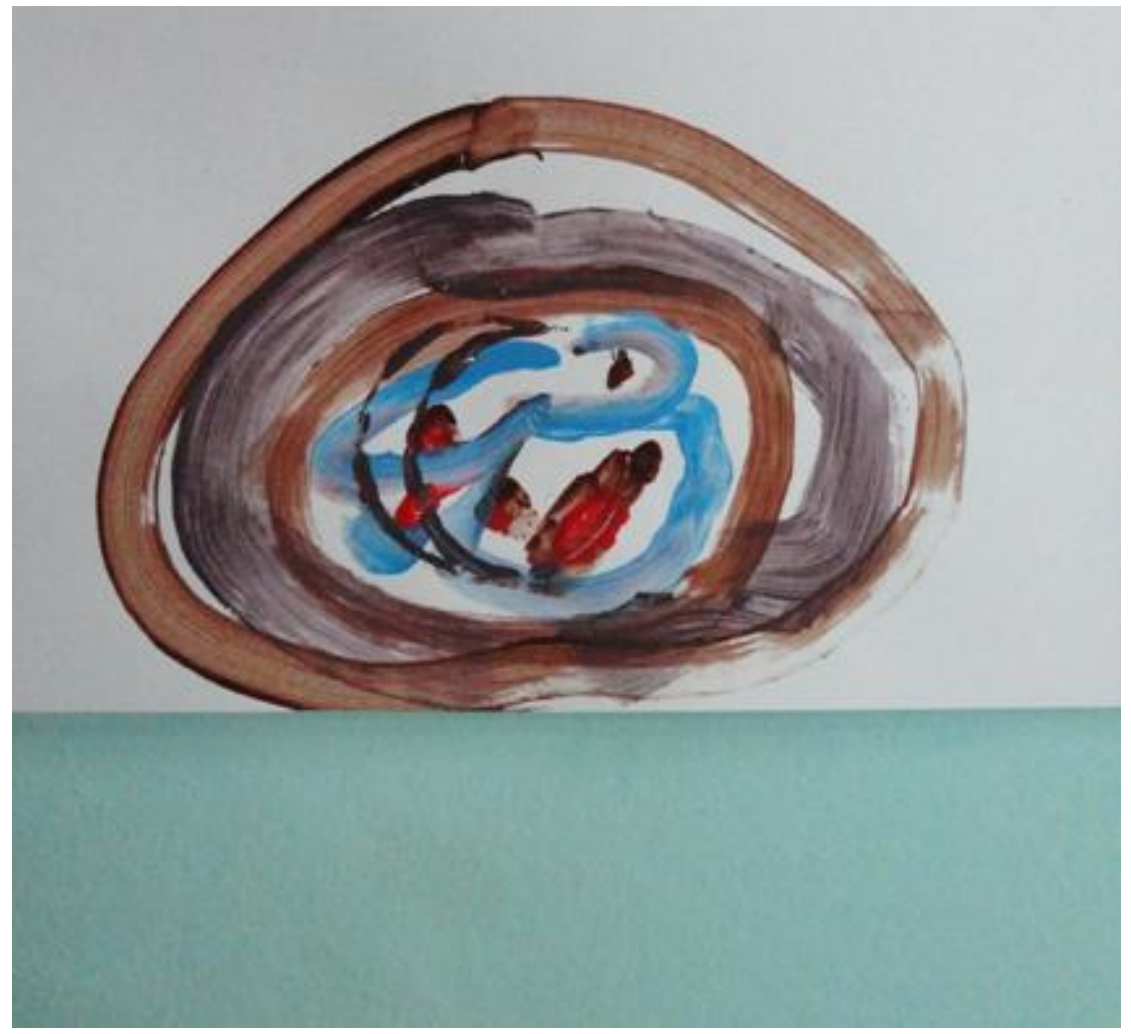

Figura 75 - Detalhe do desenho coletivo feito por Guilherme 


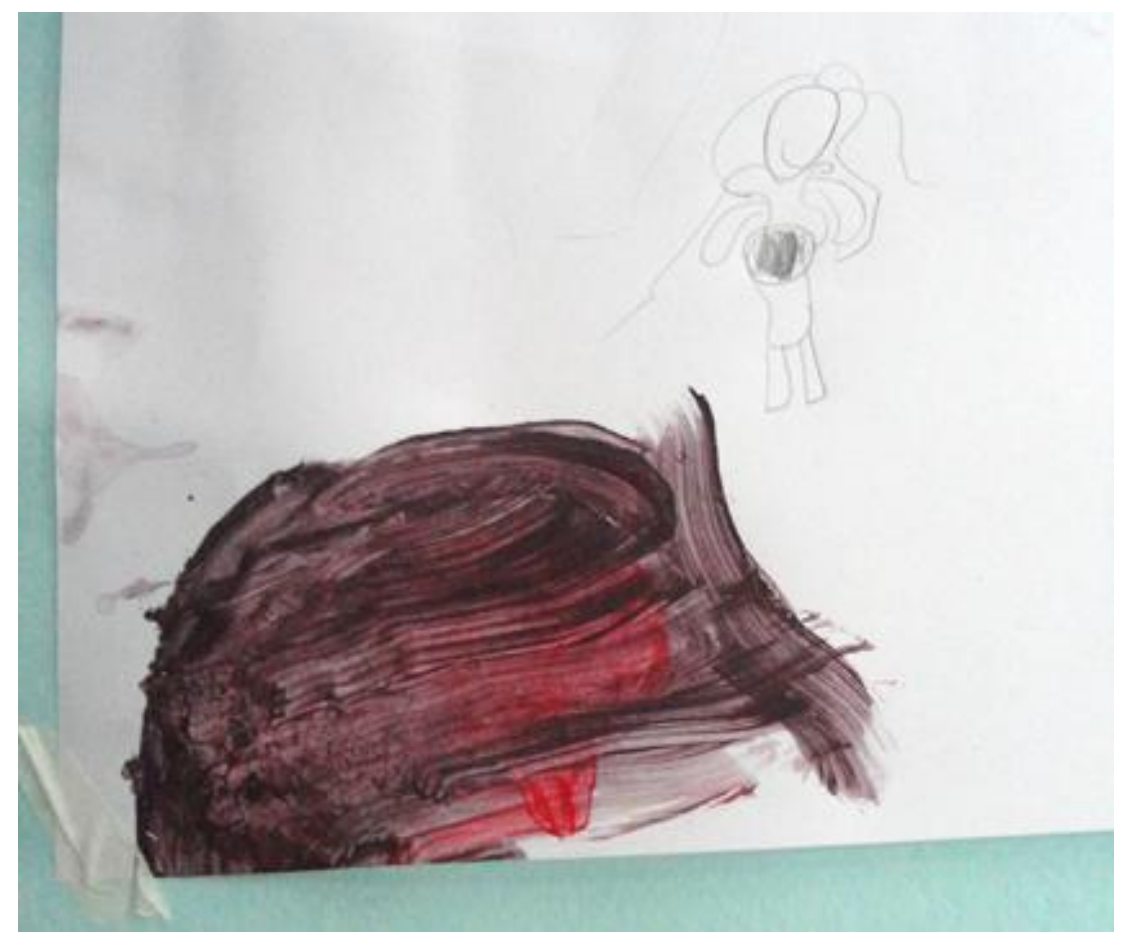

Figura 76 - Detalhe do desenho coletivo feito por Guilherme.

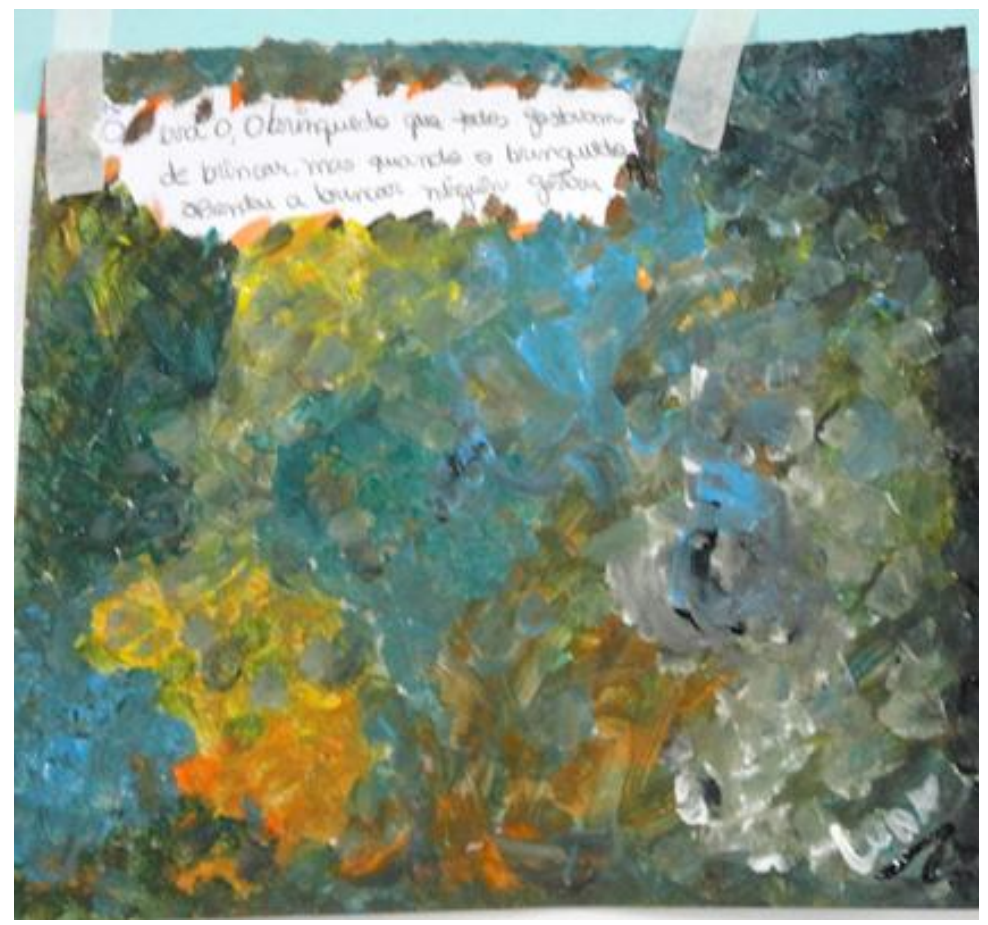

Figura 77 - Desenho feito por Leandro no décimo segundo encontro onde se lê: "Era o brinquedo que todos gostavam de brincar, mas quando o brinquedo aprendeu a brincar ninguém gostou". 


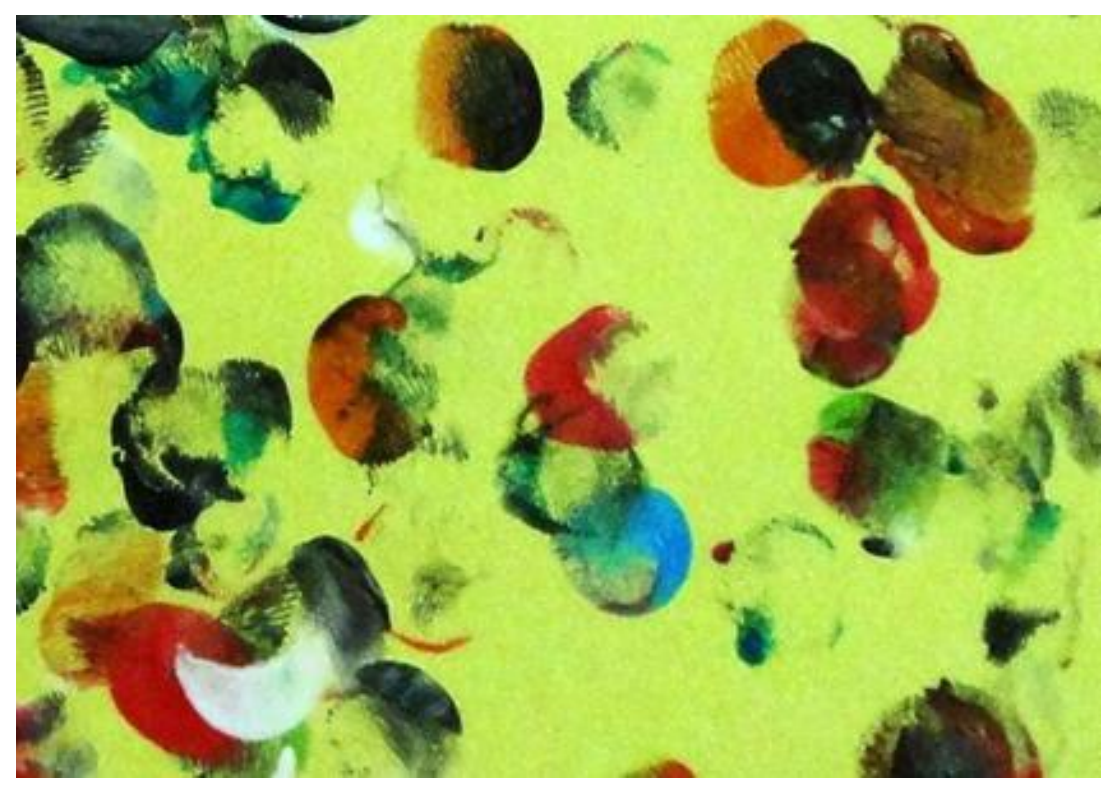

Figura 78 - Desenho 2 de Leandro no décimo segundo encontro.

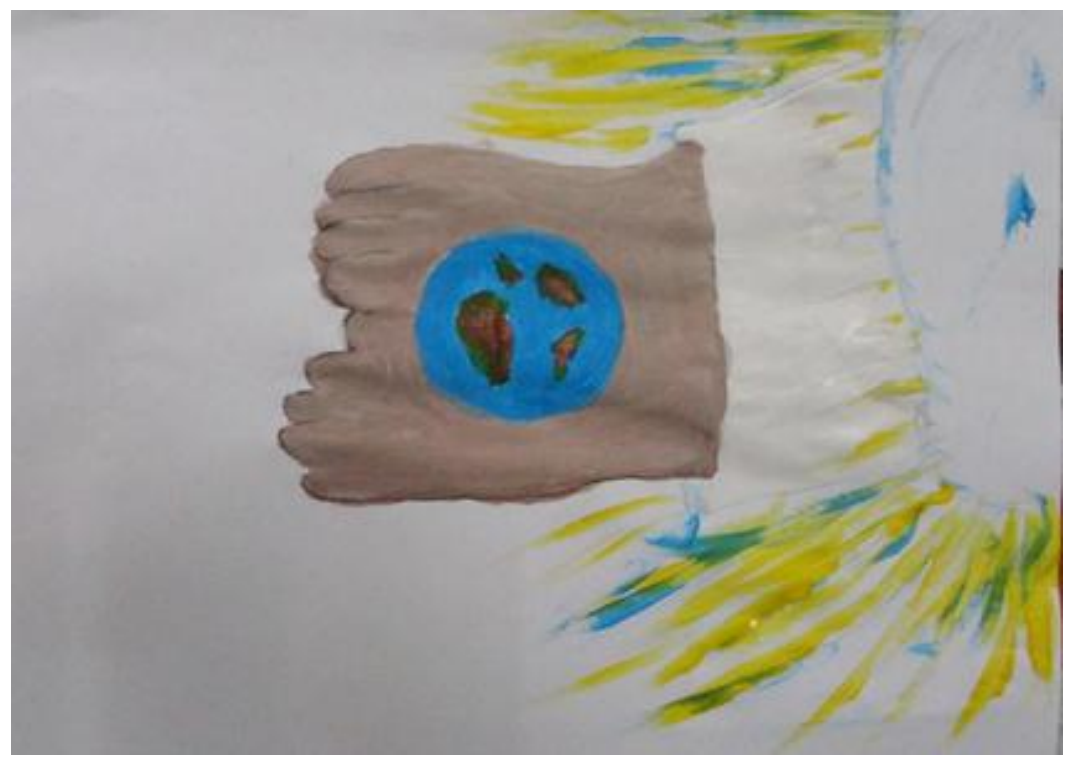

Figura 79 - Desenho de Paula no décimo segundo encontro. 


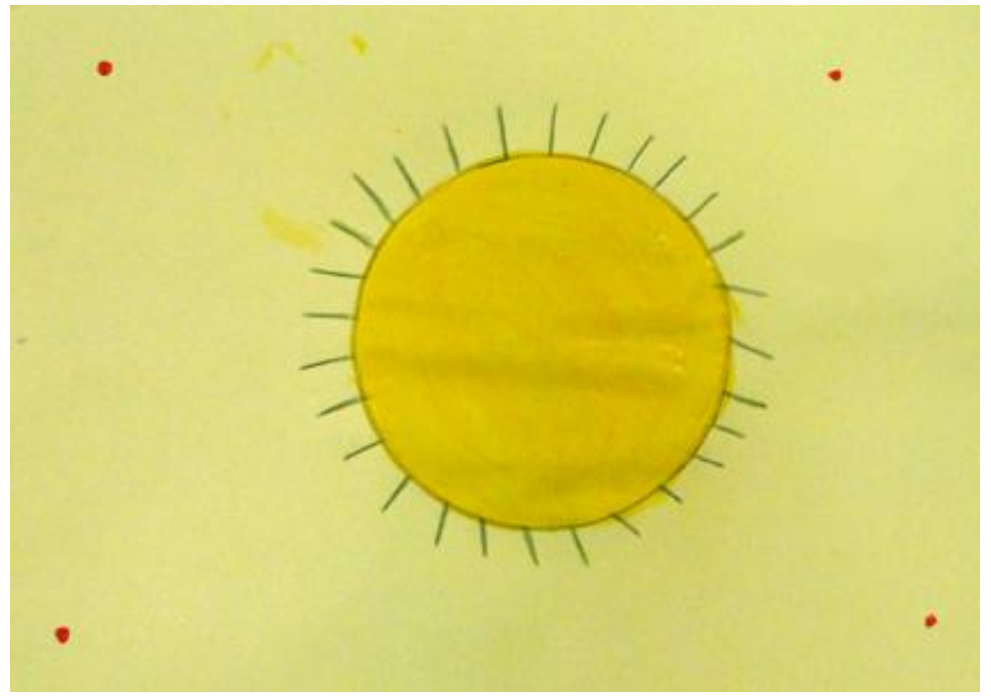

Figura 80 - Desenho de Mariana no décimo segundo encontro.

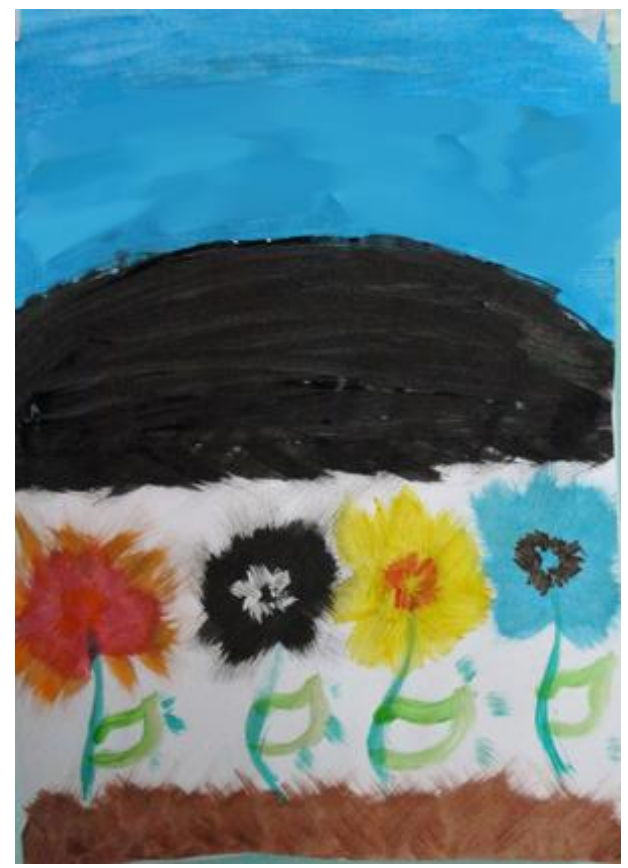

Figura 81 - Desenho 1 de Josi no décimo segundo encontro 


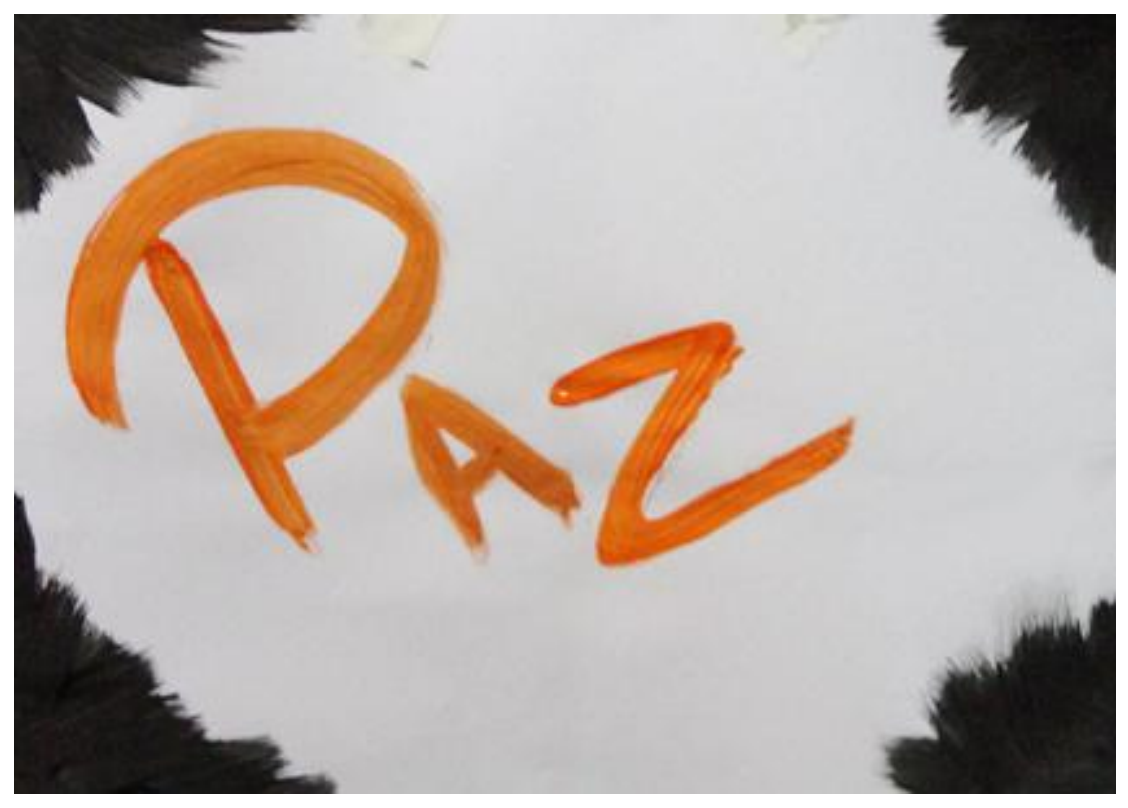

Figura 82 - Desenho 2 de Josi no décimo segundo encontro.

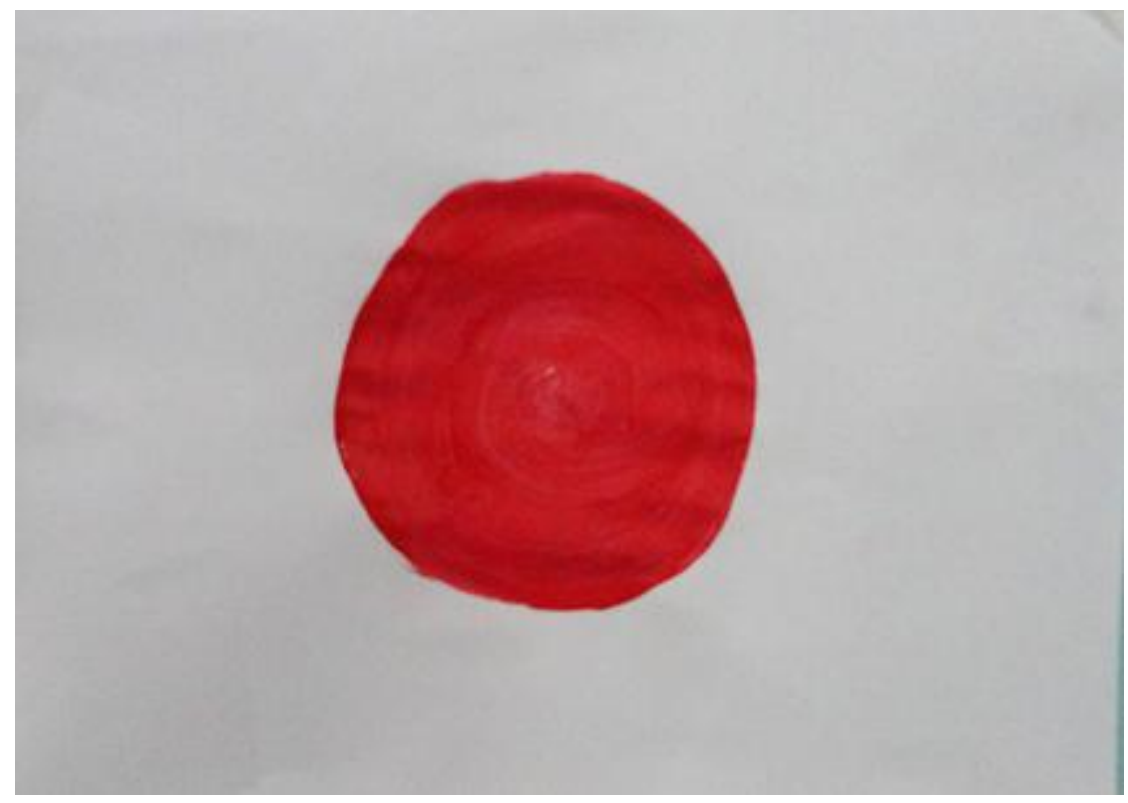

Figura 83 - Desenho 1 de Guilherme no décimo segundo encontro. 


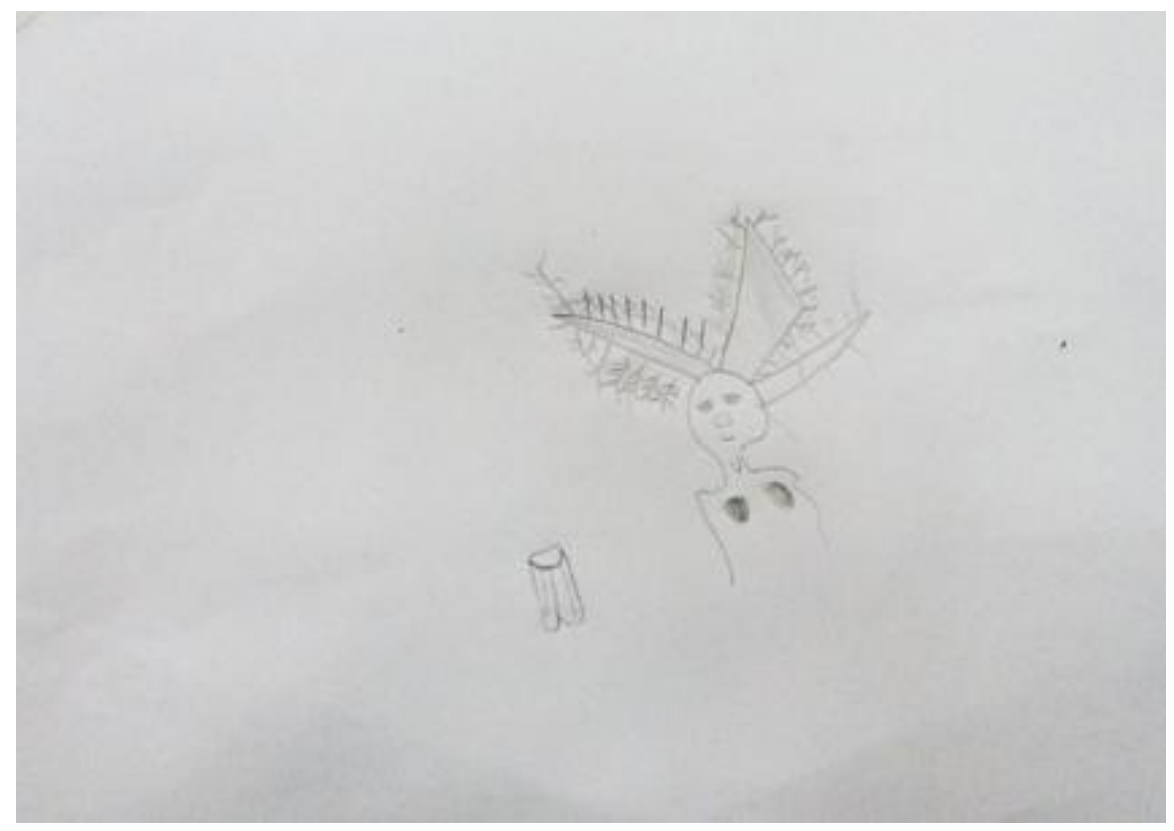

Figura 84 - Desenho 2 de Guilherme no décimo segundo encontro.

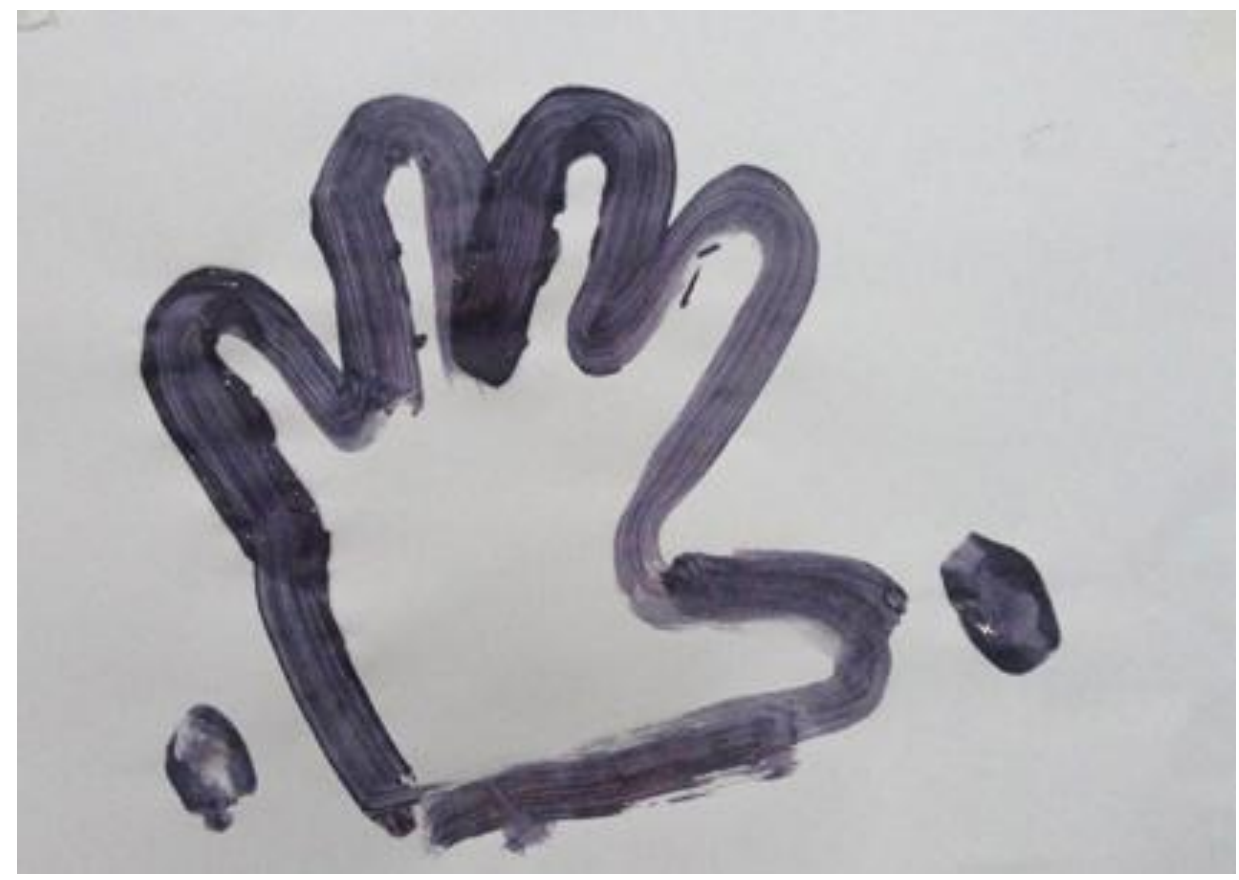

Figura 85 - Desenho de Kevin no décimo segundo encontro. 


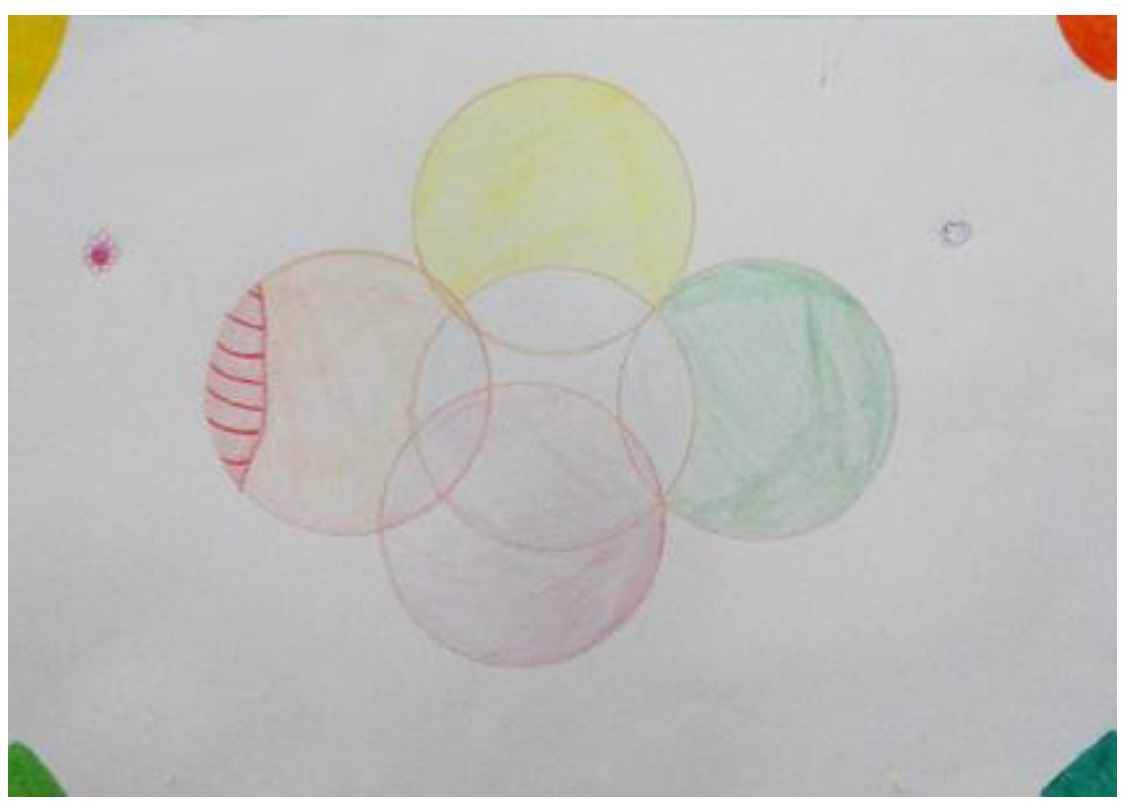

Figura 86 - Desenho de Mariana no décimo segundo encontro. 


\section{REAPLICAÇÃO DOS INSTRUMENTOS E ENTREVISTAS DEVOLUTIVAS}

A reaplicação dos instrumentos e a entrevista devolutiva com os participantes da oficina se deram na semana imediata ao término. Como as aulas já havia começado, estavam na casa apenas Maiara, Josi, Gabriela e Guilherme. Apesar de não ter participado da entrevista inicial, Guilherme fez muita questão de participar deste momento final. Como o trabalho tinha um caráter inclusivo, a solicitação de Guilherme foi atendida.

Dois instrumentos que haviam sido aplicados na entrevista inicial foram reaplicados: o CDI e o teste do Desenho da Pessoa na chuva. O CDI é um inventário que não exige intervalos longos para reaplicação, uma vez que, mensura o estado emocional do informante no momento da aplicação. Já o teste do Desenho da Pessoa na Chuva, por ser um instrumento projetivo, sugere-se que seja reaplicado a cada 6 meses no mínimo. Mesmo que a Oficina Expressiva tenha tido uma duração mais breve do que este prazo, considerou-se que o contexto de pesquisa acadêmica daria suporte a uma reaplicação investigativa acerca de possíveis mudanças no enfrentamento das pressões e tensões ambientais.

Com um intervalo de duas semanas, foi realizada a entrevista devolutiva com a coordenadora do abrigo e a psicóloga. Nesta ocasião foram discutidos alguns temas relevantes dos participantes e do funcionamento institucional, sem se expor de forma anti ética os pormenores do processo. 


\section{Entrevistas devolutivas com os participantes}

Inicialmente, apresentamos os resultados da reaplicação do CDI e do Teste do Desenho da Pessoa na Chuva. Em seguida, exporemos a síntese das entrevistas finais realizadas individualmente com cada participante. Ainda será encontrada uma entrevista com a equipe técnica da instituição. Estes encontros finais procuraram integrar os dados obtidos no psicodiagnóstico inicial e final, bem como, o processo desenvolvido ao longo das Oficinas de Desenho e Pintura.

\section{a) Resultados da reaplicação do CDI e Desenho da Pessoa na Chuva}

Para uma visualização geral dos resultados obtidos nas reaplicações aplicações do CDI e do Desenho da Pessoa na Chuva, apresentamos os dados nas tabelas a seguir:

Tabela 3 - Desenho da Pessoa na Chuva - primeira e segunda aplicação

Primeira aplicação Segunda aplicação




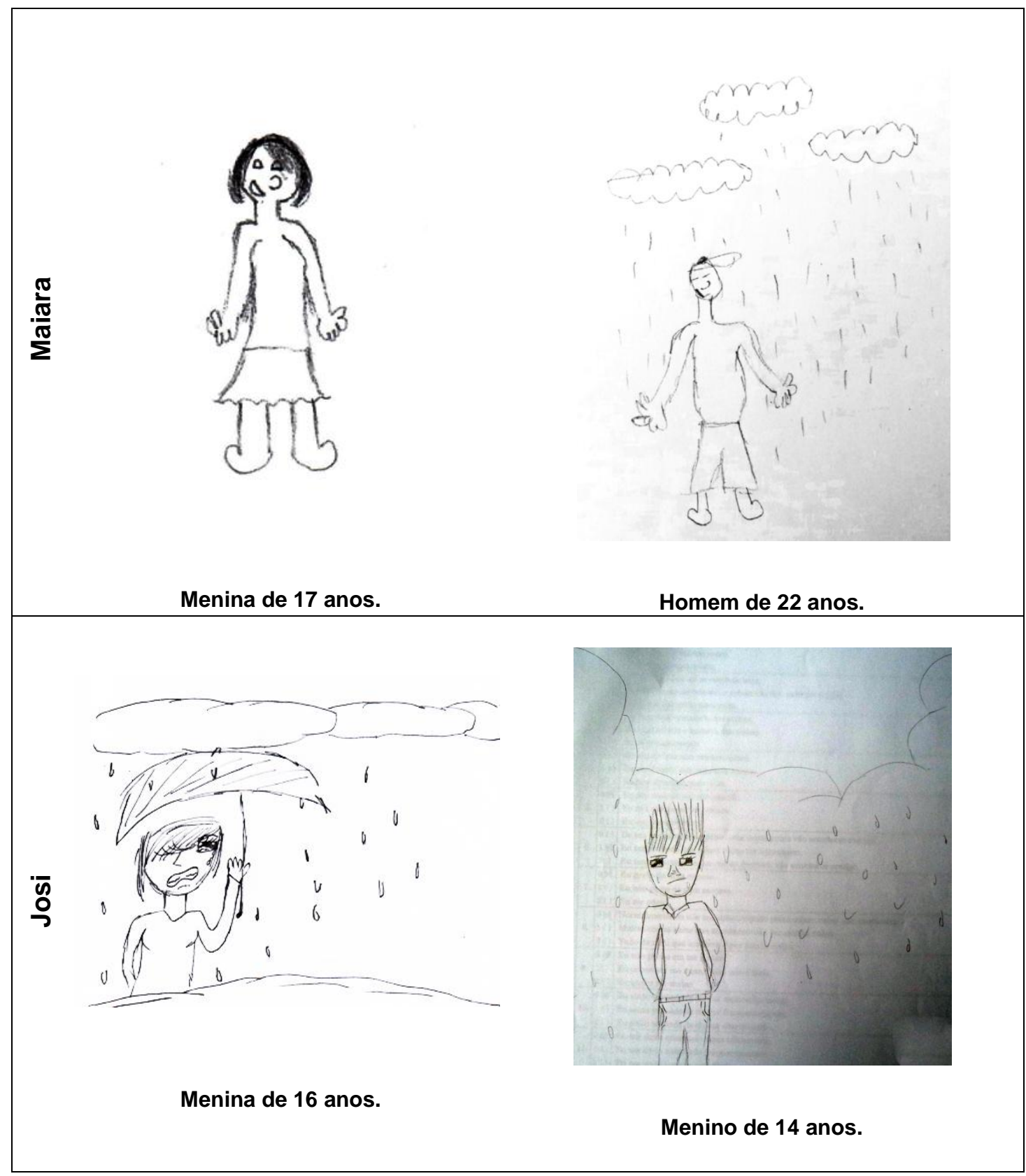

Tabela 134 - Pontuação no CDI - Primeira e segunda aplicação CDI

Ponto de corte $=17$

Primeira Aplicação

Segunda Aplicação

$\begin{array}{ccc}\text { Gabriela } & 19 & 34 \\ \text { Maiara } & 13 & 17 \\ \text { Josi } & 13 & 14 \\ \text { Guilherme } & --- & 13\end{array}$




\section{b) Entrevistas finais}

\section{GABRIELA}

A reaplicação do $\mathrm{CDI}$ indica um agravamento do estado depressivo de Gabriela. Neste inventário a menina praticamente dobrou sua pontuação, passando de 19 para 34 pontos.

Começo a entrevista por ela, que tinha natação e teria que sair em seguida. Digo que senti sua falta nas últimas oficinas e pergunto por que faltou. Responde-me que sentia muitas saudades da mãe e quando se sente assim não consegue fazer nada. Comento que este talvez fosse o mesmo motivo que a fazia ficar muito quieta nos primeiros encontros e ela acena positivamente. Recupero os desenhos que fez dos educadores da instituição com muitos braços e pernas, retomando o quanto, no início havia sido muito difícil se adaptar. Ela acrescenta que já vê os educadores de forma diferente. Até relaciona aqueles que mais gosta.

Conta que após o Natal não pode mais ver a família. Digo a ela o quanto tinha percebido sua tristeza por estar longe de sua mãe. Ela questiona porque ainda está impedida de ver sua família. Lembro a primeira entrevista quando não sabia dizer por que estava abrigada e volto a perguntar se agora já havia conversado com a psicóloga do abrigo e se já tinha descoberto. Ela acena positivamente com a cabeça e fica cabisbaixa.

Falo que algumas coisas que aconteciam na sua casa não eram boas para ela e por isso estava no abrigo, esperando que sua família pudesse se reorganizar para recebê-la de volta. Gabriela se mostra impaciente e diz não aguentar mais ficar no abrigo.

Quando sugiro o Desenho da Pessoa na Chuva, Gabriela pergunta se pode fazer com lápis colorido. Não me oponho e em seguida, depois de alguns segundos de reflexão, pede permissão para desenhar toda a sua família. Representa a mãe, o pai, ela e o irmão. Quando aponta cada pessoa da família há uma confusão entre que "boneco" seria ela e a mãe. Em relação ao Desenho da Pessoa na Chuva aplicado na primeira entrevista individual vemos a manutenção das figuras 
empobrecidas, esquemáticas, representadas por bonecos-palito. Em contra partida a cor, confere uma nova informação que traz à tona os afetos.

Ao final, conta que gostou de participar das oficinas, mas tem dificuldade de especificar. Digo para Gabriela que foi muito importante tê-la naquelas encontros, ainda que, em alguns momentos, tenha sido muito difícil para ela participar.

\section{MAIARA}

Maiara apresentou um acréscimo na pontuação do CDI (de 13 para 17 pontos).

$\mathrm{Na}$ entrevista se mostra muito amuada, mas não está aberta para contar o que sente. Pergunto como está a situação com Josi, já que estavam brigadas nas últimas oficinas. Ela diz que já fizeram as pazes e tudo voltou ao normal.

Retomo o resultado anterior do CDI em comparação com este e explico que o inventário se propõe a averiguar algumas coisas que podem estar entristecendo a menina. Ela ouve atentamente e me pergunta o que significa sua pontuação ter aumentado. Digo que, desta segunda vez, ela pode me contar mais coisas que a deixam tristes. Acrescento que é importante dividir esses sentimentos com alguém. Ela ouve tudo calada.

Em relação ao desenho da Pessoa na Chuva, pergunto se ela se lembra do que havia desenhado antes. Menciono a ausência da chuva na primeira aplicação. Ela sorri e diz que tinha esquecido. O fato de, nesta segunda aplicação, desenhar o personagem totalmente à mercê da chuva, nos evidencia uma mudança de postura de Maiara que sabemos não ter nada a ver com um simples esquecimento. Se antes a menina negou a chuva ao não representá-la, desta vez mostrou toda a sua fragilidade diante das tensões ambientais e a ausência de recursos internos para lidar com elas. Nesta segunda ocasião, não só a chuva se fez presente como as nuvens, entendidas como mais um índice da pressão vivida pelo sujeito. 
Assim como Gabriela, ao final, pergunto o que achou da Oficina e Maiara simplesmente diz que gostou, mas não se alonga no assunto. Agradeço a participação na Oficina, mesmo que tenha ficado algum tempo ausente por causa das férias.

\section{JOSI}

Josi apresenta-se de uma forma muito semelhante à Maiara: calada e um pouco desvitalizada.

Sua pontuação no CDI quase não sofreu alterações. Explico o que 0 Inventário se propõe a medir e ela confirma que tem algumas tristezas, mas que a vida deve continuar. Retomo aquela oficina em que ficamos a sós e o quanto conversamos sobre o que a entristece. Ela não fez qualquer comentário, apenas acenou positivamente.

No desenho da Pessoa na Chuva, Josi se mostra menos reativa do que na primeira aplicação. Enquanto o primeiro desenho representava uma menina com a mesma idade do que ela, com uma expressão raivosa e um guarda chuva que parecia impedir que as nuvens descessem; neste segundo desenho, faz uma rapaz mais novo, no meio de uma grande nuvem baixa como uma neblina espessa. Diferente do desenho anterior, ele não apresenta qualquer aparato de proteção e nem se mostra raivoso, pelo contrário. É representado com um olhar triste, com gotas de chuva que the escorrem pelo corpo e as mãos atrás das costas numa postura menos combativa do que na outra produção gráfica.

Retomo com a adolescente a tristeza vivida na ocasião das férias de Maiara e como reagiu diante do sofrimento sentido. Digo que, muitas vezes, a raiva e o mau humor pode esconder outra coisa que vai dentro de nós. Ela fica com os olhos marejados, mas não fala nada.

Quando Ihe pergunto sobre o que achou da Oficina, também diz que gostou e que achou muito interessante porque percebeu que, através dos desenhos, muitos assuntos importantes eram comunicados para o grupo. Confirmo para ela que este 
era o propósito do trabalho. Ela ainda comenta o pesar de Roberto não ter participado em todos os encontros.

Agradeço à Josi pela sua assiduidade, pois foi a única participante que não faltou em nenhum encontro. Comento o quanto isso mostra que valorizou aquele momento e, algumas vezes, se esforçou para estar ali, mesmo que não estivesse tão disposta. Também agradeço a solicitude nos últimos encontros ao me ajudar a arrumar os materiais.

\section{GUILHERME}

Quando cheguei para fazer estas entrevistas finais, Guilherme vai ao meu encontro, pergunta o que fui fazer e diz que também quer participar. Com os olhos um pouco assustados me conta que, finalmente, chegou o dia de voltar para casa. $\mathrm{Na}$ manhã seguinte seguiria viagem para sua cidade natal e voltaria a morar com a mulher que o havia criado por toda a vida.

Depois de conversar com as meninas, chamo Guilherme que aguardava no refeitório, ansiosamente.

Aplico o CDI, ao qual apresentou uma pontuação de 13 pontos que o situa abaixo do ponto de corte, não indicando um estado deprimido.

No momento da proposição do desenho da Pessoa na Chuva, diz que não quer desenhar. Reafirma o seu regresso ao lar e percebo que gostaria de conversar a respeito. Retomo o quanto ele tinha esperado por este momento e o quanto tinha sido difícil aguardar a decisão do juiz. Lembro que ele chegou ao abrigo mais ou menos no mesmo momento que eu comecei o trabalho e me lembro dele, a cada semana, dizer que queria voltar para casa.

Ele fica emocionado e diz que está com um pouco de medo, mas não sabe bem do quê. Conta que gostou muito da Oficina e o quanto aqueles momentos tinham-no ajudado a se acalmar e ter paciência para esperar a decisão judicial. Ao final, me abraça muito forte e diz: "Não vou me esquecer de você". 


\section{ROBERTO}

Encontro com Roberto muito rapidamente. Comento que na semana anterior havia encerrado a Oficina. Ele diz que estava de folga, porque era feriado. Digo que estou ali para fazer uma entrevista para finalizar com as meninas e Guilherme e gostaria muito de falar com ele.

Roberto se desculpa e diz que tem que fazer um trabalho fora do abrigo e não poderá ficar. Ainda digo que na semana seguinte, voltaria para falar com a equipe técnica do abrigo. Ele se compromete que, nesta ocasião, conversaria comigo.

Na semana seguinte, encontro com ele que confirma a entrevista. Porém, quando saio da sala da coordenação, após ter conversado com a coordenadora e a psicóloga da instituição, Roberto havia saído.

Este comportamento de Roberto está no mesmo fluxo que vinha apresentando nas últimas oficinas: mostrava-se solícito e interessado, porém não estava disponível.

De fato, Roberto é uma figura central na instituição e desempenha muitas funções, de modo que conseguiu participar da Oficina com limitações até que não sustentou mais as vindas.

\section{Entrevista final com a equipe técnica do abrigo}

A partir do trabalho realizado nas oficinas e no psicodiagnóstico, alguns assuntos foram trabalhados com a psicóloga do abrigo e a diretora.

A primeira questão foi a situação de Gabriela. A diretora e a psicóloga do abrigo encaravam com preocupação o comportamento da menina. Relatam que Gabriela já havia fugido para encontrar com a mãe e temiam, inclusive, que tivesse algum impulso suicida. Reconheciam alguns sintomas depressivos e por isso, julgavam que para ela estava sendo muito penoso ficar longe da família. 
Por isso, estavam considerando muito seriamente entrar com um pedido para que a juíza autorizasse as visitas acompanhadas. A psicóloga do abrigo havia feito algumas visitas domiciliares que mostraram certas inadequações que traziam preocupações com a volta de Gabriela para casa. A família morava numa casa pequena situada num terreno onde havia várias outras iguais. Na casa da frente morava o agressor de Gabriela, mas que havia sumido.

A partir das visitas e de conversas com Gabriela, formulou-se uma hipótese de que a própria mãe poderia ter um caso com o agressor da filha e que haveria alguma compensação financeira pelo consentimento da família no relacionamento dele com a menina. Acusações muito graves e que inviabilizam qualquer retorno de Gabriela para casa naquele momento. Nestas conversas com a menina, a psicóloga relatou algumas verbalizações de Gabriela que indicavam certos questionamentos acerca do comportamento dos familiares e a falha ocorrida em seu cuidado. O pai da menina foi descrito como uma figura passiva diante da mulher que não permitia, sequer, que ele respondesse aos questionamentos da psicóloga.

Tais reflexões de Gabriela apontam para o momento integrativo da menina que se expressa no segundo desenho da Pessoa na Chuva, no qual representa toda sua família embaixo da chuva, sem qualquer estrutura para lhe dar segurança. A psicóloga mostrou-se uma pessoa em quem Gabriela confia e se abre, dando abertura para ouvir certos apontamentos fundamentais para elaborar toda a situação grave que viveu.

Outro aspecto abordado foi a queixa principalmente de Josi sobre a falta de liberdade dentro da casa. A diretora do abrigo após a minha explanação disse que as queixas de Josi não procediam. Muito pelo contrário. Conta que a adolescente era incentivada constantemente para que saísse, encontrasse amigos, e até dinheiro era lhe dado para ir ao cinema, ou comprar um sorvete. Porém ela se recusava terminantemente. A diretora e a psicóloga da instituição afirmam que esse incentivo visava ao futuro desacolhimento de Josi, que precisava aprender a circular pelo mundo. No mesmo sentido, era incentivado o contato dela com a mãe, para ter alguma referência fora da casa abrigo. Josi também se recusava. 
Ressalto a importância deste trabalho que é realizado com Josi sobre seu desacolhimento. Nota-se uma preocupação e uma sensibilidade grande da equipe técnica em construir uma rede antes da saída da adolescente da instituição. Fica claro o quanto Josi parece não se sentir preparada para essa saída que se daria dali a um ano mais ou menos. Pelo que é contado, ela mesma se priva de uma série de possibilidades por temer a vida fora da instituição, o que, consequentemente, nos indica o quanto se sente protegida ali dentro. Não nos esqueçamos de que ela está abrigada desde os sete anos e este temor é mais do que compreensível. A vida dela se deu dentro das instituições de acolhimento, e, de fato, deve ser muito assustador, não poder mais se ver ali. Diferente de jovens que saem de casa em outro contexto, no caso de adolescentes abrigados, o desacolhimento se dá de forma compulsória, e se não for feito um trabalho cuidadoso, pode ocorrer repentinamente sem que o jovem possua ferramentas para se cuidar sozinho.

O retraimento de Maiara surgiu como grande preocupação da coordenadora. Muitos esforços em vão foram empregados para que a menina falasse de seus sentimentos. Em compensação, Maiara está bem encaminhada para voltar a morar com o irmão. A mãe dela se mostra estável no seu tratamento, mas não apresenta condições de ficar com a filha ainda. Afirmo o quanto a ligação afetiva que Maiara e Josi possuem é importante e sustentadora para ambas.

Falo também sobre a ausência de Roberto nas oficinas. A diretora se desculpa e diz que não sabia o quanto ele estivera ausente resolvendo questões da casa. Comentei com pesar o fato de Paula, uma educadora tão sensível e interessada não ter sido autorizada a participar mais ativamente das atividades. A diretora me explica que apesar de Paula ter de fato uma sensibilidade grande no trato com as crianças, sua função na casa não permitia sua participação mais ativa. E adentramos numa questão muito séria para este abrigo.

Como já mencionado, as oficinas apresentadas nesta dissertação foram realizadas num abrigo municipal. Isto implica que os funcionários não podem ser selecionados de maneira particular, pois adentram a instituição por concurso público ou são transferidos de outros órgãos governamentais. A consequência é a admissão de pessoas que não possuem qualquer afinidade com a tarefa de cuidar de crianças e adolescentes. Relatam o episódio infeliz, no qual uma educadora, que já 
apresentara outros comportamentos inadequados, havia discutido com um adolescente e falado de uma forma cruel sobre a mãe dele tê-lo abandonado. O menino fez uma reclamação à diretora que pediu esclarecimentos à funcionária e diante da confirmação do ocorrido, havia tomado a decisão de transferi-la para outro órgão e afastá-la do abrigo. Como se tratam de pessoas concursadas, a demissão pura e simplesmente não é possível e a transferência imediata também nem sempre é viável.

Os funcionários prestam concursos para cargos específicos. E não raro, uma pessoa que entrou para desempenhar uma função operacional (por exemplo, faxina), mostra-se um educador muito sensível, mas o remanejamento do cargo não é permitido. Em outras palavras, um educador que passa num concurso para um cargo operacional não poderia atuar como educador e vice versa, o que cerceia uma liberdade de gestão do abrigo e empobrece as possibilidades de contato com os abrigados.

Essa dinâmica delicada em relação aos funcionários foi o que impeliu a diretora do abrigo a, desde o início, insistir que seria necessário um trabalho terapêutico com os cuidadores.

Em relação à Guilherme, contam que havia voltado para casa na semana anterior e as últimas notícias era que estava muito bem com a mãe de criação. Sempre foi um menino que deu muito trabalho enquanto estava institucionalizado, mas este comportamento inadequado era entendido como o intenso desejo de voltar para a casa da mãe. Por determinação judicial, ele teve que ficar na instituição enquanto todos os trâmites eram realizados, o que demorou cerca de 3 meses.

A Oficina foi encarada como um momento valioso de mudanças e comunicações que proporcionaram um olhar sensível sobre a realidade de cada participante diante do contexto da institucionalização. A psicóloga e coordenadora do abrigo valorizaram o espaço da oficina por realizar um trabalho que elas, por integrarem a instituição, não conseguiriam com o mesmo distanciamento. 


\section{COMPREENDENDO O PROCESSO}

Como processo, entendemos todas as atividades realizadas, desde a entrevista inicial que abarcou o levantamento de informações da história de vida dos participantes e a aplicação de instrumentos de exame psicológico; os doze encontros que compuseram a Oficina de Desenho e Pintura e as entrevistas finais individuais com as crianças e adolescentes abrigados e com a coordenadora do abrigo. Na ocasião das entrevistas finais, as aulas já haviam começado, sendo assim, aquelas crianças que participaram no período das férias não estavam na casa. Portanto, somente Maiara, Josi, Gabriela e Guilherme foram entrevistados.

Este capítulo foi dividido em quatro partes nas quais se discutiu os temas mais relevantes surgidos no processo. Primeiramente nos ateremos a examinar o primeiro encontro, encarando-o como um momento de comunicação e elaboração dos principais conflitos que surgiram nos encontros subsequentes. Somando-se aos dados colhidos no diagnóstico e na entrevista inicial, o primeiro encontro produziu uma síntese de cada participante e do grupo que será pormenorizada nos dois itens seguintes. Nestes, analisou-se as referências aos vínculos afetivos sob o viés da chegada, adaptação, a vida no abrigo e o desacolhimento. Ao longo das atividades, as relações afetivas mostraram-se de grande importância para o grupo, por isso a compreensão do processo tendeu para este ponto. No último tópico, a discussão se dirigiu ao enquadre diferenciado escolhido se atendo a como sua estrutura possibilitou a emergência de experiências mutativas.

\section{O primeiro encontro e seus principais tópicos}

Assim como o diagnóstico compreensivo nos fornece uma apreensão ampla do que se passa com o sujeito no momento da aplicação (TRINCA, 1972), o primeiro encontro desta Oficina também funcionou como um momento de compreensão global de como cada participante lidava com a questão do acolhimento institucional. 
Como já mencionado no capítulo destinado à metodologia, o primeiro encontro teve uma proposta temática: "A minha vida no abrigo". Ancorado no uso do desenho temático a partir do estilo Ser e Fazer buscamos um tema convergente a todos os participantes (MANNA et al., 2012) e aos interesses desta pesquisa.

A proposição funcionou como um facilitador do primeiro contato com os materiais e a terapeuta, bem como da comunicação em si. Por ser amplo, buscou-se um tema capaz de proporcionar uma antevisão da realidade do abrigo do ponto de vista dos participantes. Constituiu-se como uma proposta muito bem vinda, tanto por propiciar um ambiente acolhedor, como por revelar, de forma condensada, os principais temas que estavam em jogo para aqueles participantes.

Aberastury (1979/1986), ao teorizar sobre o atendimento psicanalítico de crianças, afirma que, na primeira sessão, seja ela diagnóstica ou início da análise, já é possível delimitar as fantasias inconscientes de enfermidade e de cura. Estes conceitos podem ser estendidos ao contexto da oficina expressiva realizada. Compreendendo desta maneira, viu-se a primeira oficina como contentora das expressões dos principais conflitos vividos pelo grupo em torno da realidade do abrigo e os possíveis caminhos para a superação dos mesmos.

Turato (2004), ao abordar o método clínico, aponta que este se fundamenta nas trocas afetivas, na escuta da fala do sujeito, e também dos aspectos globais da linguagem corporal e do comportamento durante o contato terapêutico. Os desenhos, os temas conversados e a linguagem não verbal apontaram para um tema de extrema relevância no conjunto dos doze encontros: a complexidade dos vínculos afetivos durante o período de acolhimento. Esta questão pode ser compreendida como uma moeda de duas faces: de um lado temos as relações intricadas que envolvem abrigados e funcionários; e de outro, observa-se a retomada e a reestruturação dos vínculos afetivos com quem está do outro lado dos muros do abrigo.

A primeira questão que surge nesta oficina expressiva é o comportamento de Gabriela que indica o desconforto vivido pela menina e a reação dos outros participantes frente a isto. Gabriela, neste primeiro momento, foi incapaz de escolher o papel que gostaria para seu desenho ou de se expressar de qualquer outra forma. A dificuldade de comunicação na menina já se esboçara no momento do diagnóstico 
inicial. A ausência de boca no Desenho da Pessoa na Chuva; a fábula VI, na qual o elefante não tem com quem conversar; e a resposta dada no IFVD "tenho medo de contar o que acontece comigo" são todos índices do quanto a expressão do que se passa internamente estava comprometida.

Em Winnicott (1971/1975:63), se observa que o espaço terapêutico se configura como uma forma altamente especializada do brincar a serviço da comunicação consigo mesmo e com os outros. Entendemos a dificuldade de Gabriela no que diz respeito à comunicação neste primeiro contato na Oficina Expressiva, como uma inibição diante do convite para o brincar espontâneo (WINNICOTT, 1971/1975) através do desenho. Isto indicou a gravidade de seu estado psíquico, que seria reforçado pela qualidade de sua produção gráfica no momento diagnóstico e na Oficina. Diante disto, ficaram evidentes as dificuldades que tal condição emocional acarretava na estruturação dos vínculos afetivos entre ela e as outras meninas que chegavam a ficar impacientes diante da sua inquietude e ausência. Com o passar do tempo, foi possível compreender que este comportamento de Gabriela refletia não só o estranhamento diante da nova condição de acolhimento, mas o sofrimento da menina pelo afastamento das figuras parentais.

Por ser uma instituição temporária, onde crianças e adolescentes vem e vão cotidianamente, o momento inicial de chegada ao abrigo, a adaptação e a receptividade daqueles que ali já estavam, configurou-se como um tema importante para o entendimento daquela realidade.

Em contraposição ao grande desconforto vivido por Gabriela diante da configuração da instituição, Josi, Maiara e Roberto demonstraram uma enorme desenvoltura e naturalidade no trato um com o outro. Josi e a Maiara relatam que convivem juntas em instituições desde 2007. Esse fato possibilitou a formação de um vínculo fraternal entre ambas que demonstram sua cumplicidade ao retratarem uma a outra em seus desenhos e o comportamento evidente.

Apesar de não constar no ECA (BRASIL, 1990/2005) qualquer referência ao tempo máximo de institucionalização, a noção de que a institucionalização não deve se prolongar por muito tempo é muito apregoada. Josi estava acolhida há 6 anos, enquanto Maiara estava há 5 anos. Este tipo de caso não é tão raro quanto deveria 
ser (IPEA, 2003). Josi e Maiara era exemplos desta realidade. Por outro lado, foi o longo período passado juntas que permitiu o fortalecimento do laço afetivo entre ambas.

O desenho de Roberto evidencia que as relações afetivas no abrigo também era uma questão complexa para ele. Esteve em jogo para o educador sua dificuldade em administrar o enorme afeto que nutria pelas crianças e o limite que sua posição hierárquica lhe impunha. Aspecto que já havia sido exposto na entrevista inicial.

A fantasia de um educador se tornar de fato da família de um dos abrigados surge expressamente quando Josi relata que um ex educador estava, na época, em vias de adotar um dos meninos da casa. Além disso, no seu desenho a jovem representa o educador que fala: "Até pareço tio", o que reforça esta percepção. Em contrapartida, Roberto em seu desenho deixa claro o quanto é difícil manter certa distância afetiva, que fica evidente quando relata, até mesmo em seus dias de folga, passar no abrigo ou telefonar para saber se está tudo bem.

A situação familiar de cada uma das meninas que foram mais assíduas nas oficinas era bastante diversa, consequentemente, a posição de cada uma frente ao desacolhimento era igualmente distinta. A condição variava desde o impedimento de visitas familiares de Gabriela; a aproximação bem sucedida de Maiara com o irmão mais velho e a chegada da maioridade civil de Josi que a colocava às voltas com uma cobrança de responsabilidade que se expressa claramente apenas na penúltima oficina.

Com o tempo, evidencia-se a contradição entre as dificuldades de relação das meninas e seus familiares de origem e o intenso desejo em sair do abrigo. Podemos observar este ponto na projeção que Maiara e Josi fazem a partir do desenho de Gabriela: veem um foguete que representa o desejo, depositado em Gabriela, de sair do abrigo de qualquer forma. E ao lado deste foguete, veem a "porta da esperança" que nos aponta para uma projeção positiva diante do desacolhimento.

Se tomarmos um ponto de vista histórico, o abrigo como entendemos hoje descende (BAPTISTA, 2006) de instituições totais organizadas em grandes complexos afastados da malha urbana que concentravam no seu espaço físico toda 
sorte de serviços para atender as crianças e adolescentes, impedindo seu contato com a sociedade. Os jovens eram distribuídos em módulos que podiam abrigar até cem indivíduos cada, sendo organizados por gênero e idade, o que acarretava, frequentemente, na separação de irmãos e parentes. Com a promulgação do ECA na década de 1990, observou-se uma preocupação em tornar a estrutura destas instituições de acolhida mais humanizada. Os grandes complexos deram lugar a casas inseridas em bairros residenciais que acolhiam um número muito menor de crianças e adolescentes. Desta forma, criaram-se espaços de atendimento mais personalizados, fazendo jus a visão de crianças e adolescentes como cidadãos de direito (SOUZA NETO, 2001; BRASIL, 1990/2005, art. 94).

Esta transição ainda não se deu por completo como foi possível observar neste trabalho. Aspectos destes dois momentos históricos coexistem e geram conflitos no cotidiano de casas abrigo. Observando a dinâmica da casa durante a atividade, foi possível averiguar que o abrigo possui um caráter ambivalente que sustenta características totais como a restrição de circulação pelos cômodos da casa, a divisão entre alas feminina e masculina; e, ao mesmo tempo, iniciativas que priorizam o tratamento individualizado, por exemplo, a dispensa do uso de uniformes e a não coletivização completa das atividades.

Essas características se refletiram numa reivindicação por maior liberdade dentro do abrigo que foi se construindo cada vez mais expressamente por Josi e Maiara. Passarini; Colacique; Tardivo (2012) apreendeu a mesma problemática quando aplicou o Procedimento de Desenho Estória com tema em um grupo de adolescentes abrigadas junto com seus filhos. Na discussão que se seguiu a elaboração dos desenhos, surgiram inúmeras queixas das adolescentes em relação à falta de liberdade de ir e vir.

Por outro lado, a ambiguidade observada na instituição pode também ser compreendida como uma projeção da ambivalência nos vínculos, tanto entre as crianças e adolescentes acolhidos e suas famílias, como entre eles e os funcionários do abrigo. A instituição personalizada na figura dos funcionários é reconhecida ao proporcionar condições que não existem nas famílias, mas, concomitantemente, é criticada por não oferecer as condições idealizadas de cuidado. Esse aspecto dialoga com a proposição de Kaës (1991) de que toda instituição ocupa um duplo 
status psíquico: objeto ideal a ser interiorizado e o papel persecutório ao se transformar em depositária dos aspectos dissociados.

A partir do que foi dito acima, vemos que a fantasia de enfermidade assim como a de cura (ABERASTURY, 1979/1986) orbitam a esfera dos vínculos afetivos, portanto, podemos dizer que o vínculo ambíguo (que transita entre a proteção e a violência) destas meninas e suas figuras parentais é o que está no cerne da causa da experiência do acolhimento. No entanto, é também o vínculo afetivo que possibilita a esperança da cura.

Neste caso, não se trata da manutenção do vínculo ambíguo, mas o estabelecimento de relações estáveis e protetoras tanto entre os que circulam na instituição (abrigados, educadores, outros funcionários etc.) como em relação ao mundo externo a ele. $O$ temor das consequências negativas oriundas da ambiguidade do cuidado surge igualmente em Roberto, que se angustia pelo dilema entre manter uma relação calorosa com as crianças e adolescentes e ser mal interpretado como agente da repetição da violência. Como já mencionado, a própria natureza da instituição, como sendo um lugar temporário, impõe dificuldades à manutenção deste vínculo tão estreito.

Aberastury (1979/1986) coloca que, a necessidade da comunicação de tais fantasias na primeira sessão implica num desejo inconsciente de não se repetirem as experiências frustrantes que provocaram a enfermidade. Em outros termos, ao comunicarem seus conflitos, os participantes da oficina fizeram-me um pedido inconsciente para que eu não repetisse as condutas negativas que provocaram o acolhimento. De maneira igualmente inconsciente esta mensagem foi captada e modulou a minha atuação nos próximos encontros: através da manutenção do enquadre e da minha postura em garantir que, no espaço da oficina não se perpetuassem gestos que invadiriam o espaço do grupo e de cada um dos participantes, além de garantir a expressão espontânea e criativa.

Da mesma forma como os aspectos levantados no diagnóstico continuaram ressoando no primeiro encontro, veremos a seguir como estes pontos serão desenvolvidos, elaborados e integrados pelos participantes ao longo dos 11 encontros seguintes. 


\section{A chegada ao abrigo e o estabelecimento dos primeiros vínculos}

O primeiro encontro da oficina expressiva marca a minha chegada ao abrigo. Em meio à confusão relativa à também chegada de um menino novo, a minha recepção se dá de forma um pouco fria e desconfiada por parte das meninas. Mesmo após o contato comigo nas entrevistas individuais, nenhuma delas me dirigiu a palavra diretamente de modo que Roberto teve o papel da hospitalidade, de incentivar a participação e mediar o contato entre mim e elas.

Este tema da chegada ao abrigo vai se adensando conforme a atividade se desenvolve. Logo na proposição da tarefa - a elaboração de um desenho cujo tema era "Minha vida no abrigo", fica evidente o quanto, apesar de estar ali há três meses, Gabriela não se encontrava adaptada. Ela demonstrava grande desconforto em qualquer tentativa de contato por parte das outras meninas, de Roberto e minha. Era incapaz de verbalizar qualquer reação, movia-se de forma inquietante a cada tentativa de conversa e demonstrava querer falar, mas não conseguia. $O$ comportamento dela despertava muita ansiedade por parte das outras pessoas, que não raro faziam escolhas por ela. Esta ansiedade era de fato de Gabriela que só vai falar a respeito no terceiro encontro.

A inibição no comportamento de Gabriela diante do convite para o brincar espontâneo na oficina nos dá indícios da sua condição emocional. Partindo do que nos disse Winnicott (1971/1975:63), o brincar tem inúmeros papéis fundamentais, tais como: facilitar o crescimento, conduzir o indivíduo aos relacionamentos grupais, comunicação, entre outros. Consequentemente a inibição de Gabriela foi encarada com preocupação.

A expressão do incômodo causado pelo comportamento de Gabriela vai ser aos poucos, verbalizado como queixa por parte de Josi, Maiara e Roberto. No primeiro encontro, este aspecto já pode ser observado no momento em que Gabriela se vê indecisa diante da oferta de papéis para começar o seu desenho. Nesta ocasião, Maiara fala de forma impaciente, mas com um tom pedagógico: "Gabriela, você tem que aprender a falar. Fala o que você quer!".

No segundo encontro, esta queixa se torna ainda mais forte quando Josi diz que faz o possível para se relacionar com Gabriela, mas a menina não se entrosa com 
elas. Ao ouvir essa "reclamação", Gabriela, novamente, tenta falar, mas é como se as palavras não the viessem. A dificuldade de comunicação da menina pode ser entendida como mais um indicativo da inibição profunda da expressão criativa.

Josi e Maiara chegam a assumir um tom reivindicatório ao questionarem porque Gabriela não se relaciona com elas. Quem assume a palavra é Josi, e apoiada por Maiara, começa a elencar diversos exemplos de tentativas de conversa, de contato, o quanto Gabriela prefere ficar sozinha. Assume um tom queixoso, ficando implícito que é de Gabriela a culpa. Apesar de não falar nada, Gabriela revira os olhos, numa expressão de enfado e incômodo. O que considero uma comunicação mais efetiva do que vinha apresentando.

Considerei que Gabriela poderia ser depositária de conteúdos ligados à adaptação ao abrigo e suas dificuldades. Então fiquei atenta e quando surgiu espontaneamente o assunto relativo ao abrigo antigo, de onde Josi e Maiara vieram, tentei implicar as duas nesta questão e pergunto como foi a mudança do abrigo antigo para o atual. Surpreendentemente, o primeiro a falar é Roberto que vai contando todas as dificuldades que tiveram. Isso indicava o quanto esta questão não se restringia apenas a quem estava institucionalizado, mas aos funcionários também. Josi e Maiara falaram abertamente sobre o abrigo antigo. O que fica mais evidente foi a dificuldade dos adolescentes em se adaptarem às novas regras mais rígidas, pois o abrigo anterior era um ambiente completamente permissivo, tanto que foi fechado pela prefeitura. No momento da transferência, os educadores do abrigo atual foram vistos pelos abrigados como os responsáveis pelo fechamento do outro abrigo. Desta forma, muitas situações difíceis aconteceram envolvendo até mesmo ameaças de morte contra cuidadores.

Esse contexto de brigas e discussões já foi mencionado por Martinez (2006) a partir do contato com adolescentes prestes a serem desabrigados e que relatam conflitos com os educadores que se tornam receptáculos da crítica agressiva em relação às limitações do abrigo que frustram expectativas ideais. A partir de um dos casos estudados, Martinez (2006) salienta o caráter ambíguo que se situa entre as críticas e a noção de proteção. Vemos este mesmo aspecto no comportamento de Josi e Maiara ao dizerem que o abrigo anterior era "melhor", mas assumem que não era tão tranquilo e protetor quanto o atual. 
Gabriela ouve atentamente aos relatos de conflitos entre os abrigados; entre abrigados e os educadores, etc. Comento que, não é fácil chegar ao abrigo, assim, quem chega, precisa de um tempo para se adaptar. Oliveira (2006:166) em sua dissertação de mestrado aborda o quanto os adolescentes sentem-se assustados, abandonados e solitários diante dos sentimentos e do mundo novo que se abre a partir do ingresso no abrigo. A autora ressalta a importância do acolhimento oferecido pelos educadores neste momento e o quanto os abrigados se sentirão respeitados nas suas singularidades. Isso poderá culminar numa expressão dos sentimentos que estão em jogo.

Voltando ao tema da mudança de instituição, observa-se que todos os envolvidos - educadores e corpo diretivo, inclusive - tiveram que criar estratégias para se acomodar, o que fica claro na fala de Roberto. Ele relata situações de embate com os adolescentes mais velhos, que resistiam às regras e influenciavam os outros, chegando até mesmo a ameaçar os funcionários. As meninas confirmam o quanto consideravam que os funcionários do atual abrigo teriam sido os responsáveis pelo fechamento do anterior.

Mesmo constituindo-se como um ambiente inapropriado, no abrigo antigo havia laços afetivos e o rompimento das condições que mantinham aquelas relações constitui-se numa ameaça e perda para as crianças e jovens que foram transferidos. Retomando o que Bowlby (1985) escreve sobre os efeitos da perda, destaca-se a tendência para recriminar furiosamente quem quer que pareça o responsável por ela ou estar dificultando a retomada da condição anterior. É possível compreender os vários conflitos que ocorreram neste período inicial de adaptação por este viés.

Da mesma forma, os funcionários de uma casa abrigo podem sofrer ataques de raiva por serem considerados, na fantasia dos acolhidos, os responsáveis pelo afastamento das figuras parentais. Mesmo que estas tenham falhado violentamente na função protetora.

Apesar deste momento mais delicado já haver ficado para trás (pois já estavam todos bem adaptados) o abrigo configura-se como uma instituição na qual muitas chegadas e partidas acontecem, de modo que os ajustes são sempre necessários de todas as partes. Um dos adolescentes entrevistados por Martinez (2006) relata o fluxo de pessoas no abrigo: abrigados e funcionários que desistem da função. 
Durante o período da Oficina, muitas crianças e adolescentes chegaram e observei que, todos provocaram algum efeito na instituição. Não raro uma criança ou adolescente recém chegados mexia com toda a dinâmica da casa. O espaço da oficina refletiu esta questão.

Como anteriormente mencionado, os encontros tiveram a participação de outros abrigados e educadores, além dos inicialmente acertados com a direção. Guilherme é o primeiro "novo integrante" depois da acomodação dos quatro participantes iniciais. A cada nova participação, fosse de um abrigado ou de um educador, o grupo consolidado sofria um descompasso. No entanto a capacidade de adaptação era grande. Havia um reposicionamento de lugares para que a nova pessoa pudesse se inserir. Em alguns casos, esse descompasso era rapidamente solucionado. Em outros, a dificuldade era maior, como no caso de Guilherme. Ele era um menino que não estava completamente inserido na casa: ficava à margem, tinha um comportamento muito provocador, as outras crianças e adolescentes tinham reservas em relação à ele. Quando a oficina começou, Guilherme não estava abrigado havia muito tempo. De modo que o espaço da oficina colaborou para a integração dele no grupo para além daquele momento. Foi observado que, mesmo com suas brincadeiras irreverentes, ele passou a ter um lugar tanto na oficina quanto no abrigo. E houve uma acomodação mútua: ele descobrindo os limites das regras numa instituição com várias crianças e adolescentes, e os outros aprendendo a se defenderem de suas piadas inconvenientes sem precisar mantê-lo apartado.

A instituição de acolhimento, com a rotina de chegadas e partidas, sofre constantemente com esta perda de compasso no ritmo da caminhada do trabalho que ali é desenvolvido. Se por um lado, isto agrega aos que possuem maior flexibilidade uma capacidade grande de adaptação a mudanças; àqueles que tenham mais dificuldades em lidar com a inconstância podem sofrer com esta imprevisibilidade. Dell'Aglio e Hutz (2004), apontaram para o caráter impessoal dos vínculos afetivos em abrigos associados caráter transitório e temporário da instituição.

No terceiro encontro, é a vez de Roberto formular uma queixa pelo comportamento de Gabriela. Para retomar o relato, Roberto e Gabriela não participam desde o começo, pois o educador foi levar a menina ao médico, já que 
ela se queixava de dor de cabeça. Após certo tempo, ele retorna sozinho, dizendo ter deixado Gabriela no médico com uma educadora, mas que tinha certeza de que a menina não tinha nada. Fala muito irritado, de que, tudo havia sido desculpa para sair do abrigo. A rejeição de Gabriela a despeito de se fazer de tudo para que ela se sentisse acolhida não é bem elaborada. Já na entrevista inicial, Roberto relata como a maior dificuldade do seu trabalho lidar com a impotência sentida diante da recusa de uma criança ou adolescente em aceitar os esforços da equipe para "construir coisas boas". Neste momento, percebemos uma retroalimentação nestes padrões de comportamento: o desconforto prolongado de Gabriela provocava uma falta de empatia nos educadores, que, consequentemente, não se mostravam acolhedores com as angústias da menina que só ficava mais desconfortável.

Winnicott (1987/1999) afirma o quanto as crianças institucionalizadas idealizam seus lares e podem ser muito hostis com os novos cuidadores. $O$ autor ressalta 0 quanto seria importante que os profissionais que lidam com estas crianças pudessem absorver essas ondas de sentimentos negativos. No caso de Gabriela e Roberto, vemos uma dificuldade por parte do educador em lidar com a angústia da menina que estava profundamente incomodada em ficar "presa" no abrigo e precisou criar subterfúgios (mal estar) para poder sair na rua. Lembremos que, devido ao comportamento inconveniente dos pais, Gabriela sequer frequentava a escola, de modo que ficava na instituição todo tempo.

É no terceiro encontro que me proponho a conversar em particular com ela. Num ambiente mais reservado, a menina se abriu e falou da "agonia" (sic) que sentia por estar longe da mãe. Interessante notar que se utiliza do mesmo termo que usara no Teste das Fábulas, mais precisamente na fábula VI, quando fala porque o elefante está diferente. A projeção de sentimentos pessoais no personagem da história é exatamente o que caracteriza estes instrumentos projetivos de avaliação psicológica.

Winnicott (1988/2006:31) afirma o quanto a agonia é uma expressão que designa uma aflição muito primitiva. Este sentimento era tão intenso que não abria espaço para os novos vínculos que poderia se fazer ali na casa, ou até mesmo que ela pudesse se engajar em atividades. Como Bowlby (1997) afirma, em casos de afastamento da família, é importante que se criem laços com adultos substitutos. 
Neste caso, para Gabriela estava tão difícil conseguir confiar nos educadores do abrigo, que não conseguia nem ao menos se aproximar deles para ser minimamente consolada pelo afastamento das figuras parentais. Via-se muito sozinha e acuada, temendo o abandono da mãe. A falta de confiança impedia qualquer tipo de comunicação mais pessoal, como também havia surgido numa resposta do IFVD: "Tenho medo de contar o que acontece comigo".

Diante do que a menina me contou e observando seu comportamento inibido e ansioso abria-se um caminho para a compreensão do que estava sendo vivenciado por ela diante da institucionalização e, o mais importante, do afastamento da mãe. $O$ rompimento abrupto e inesperado provocou uma reação em Gabriela que inspirou cuidados intensos. Bowlby (1997), ao teorizar sobre o rompimento dos vínculos afetivos, nos esclarece que a ansiedade é uma reação esperada. O que se mostrou alarmante neste caso era a duração deste sentimento (já estava abrigada havia 3 meses e ainda se mostrava profundamente inquieta e retraída). Além disto, pelos resultados dos testes aplicados no diagnóstico (CDI E IFVD), havia uma ameaça da instalação de um estado depressivo com ideação suicida. Apesar da falha no cuidado, tudo indicava que, de alguma forma, a mãe estabeleceu um vínculo estruturante e, ao se ver sem ter acesso à ela, Gabriela sofria o desamparo.

Os sentimentos e comportamentos de Gabriela dialogam com as conclusões de Leoncio (2003) que investigou 13 crianças abrigadas e relatou que a ida para o abrigo intensificou problemas emocionais destas crianças e adolescentes exatamente por se verem separadas da família. A pesquisadora ressaltou principalmente os sentimentos de desamparo, abandono, rejeição, desproteção e solidão. Quando resgatamos a resposta da menina à fábula VI do Teste das Fábulas, vemos que ela atribui à mudança do elefante a tristeza e agonia por não ter ninguém. A obra de Bowlby (1997) também auxilia na compreensão do sofrimento de Gabriela por esta longe das figuras parentais. O autor menciona como resultantes do afastamento de familiares e da dissolução do vínculo: a aflição, o desligamento emocional e a implacável exigência para estar perto da mãe.

Seus desenhos refletiam sua condição emocional. Nos dois primeiros encontros, retrata praticamente o mesmo cenário, com diferença que, na segunda ocasião, utiliza cores. Esse gesto já mostra um impulso em tentar integrar um pouco melhor 
os afetos às suas representações. Sua primeira produção inicia muito diminuta no canto esquerdo da folha. Ao observar os desenhos dos outros participantes, apaga, e o refaz maior. Vemos duas casas, uma maior do lado esquerdo e outra menor ao lado. Ambas possuem um contorno eriçado e trêmulo. A casa maior parece estar flutuando e circundada por um retângulo. Desenha nuvens grandes e abaixo dela três flores e uma porta, também com contorno trêmulo, flutuando. Já no segundo desenho, pequenas mudanças nos indicam um movimento interior: a nuvem ocupa todo o comprimento do papel, mas por baixo, um sol desponta. Há apenas uma casa, flores, um chão e a porta flutuante. A falta de acesso à família e a ausência de qualquer perspectiva parecem estar representadas pela casa e as portas flutuantes.

Em virtude deste contexto tanto a direção do abrigo como eu, independentemente, pensamos numa alternativa para confortar esta menina, já que o rompimento do vínculo com a mãe mostrava-se tão desorganizador. Foi pensada uma forma da relação entre ela e a mãe se restabelecer, mas de modo seguro para Gabriela. Um esquema de visitas monitoradas foi pensado para que a mãe não prejudicasse a menina, uma vez que tinha uma profunda dificuldade em compreender os malefícios da relação da filha e do abusador. No entanto a inadequação da família foi muito grande. Em um conversa após um encontro, a coordenadora do abrigo e a psicóloga relatam na ocasião de visita de natal que a mãe de Gabriela fornecera o telefone celular para que a menina falasse com o seu agressor. Foi levantada a problemática de permitir a visita da família aos finais de semana quando na casa só havia um educador que não consegue supervisionar o encontro e cuidar das outras crianças da casa.

Será apenas na quinta semana, que Gabriela se mostrará um pouco mais tranquila e à vontade. Neste dia, quando inicio a atividade, Josi e Gabriela chegaram atrasadas, pois haviam ido ao cabeleireiro devido a uma festa de Natal que ocorreria no dia seguinte. Diferente de todos os outros dias, Gabriela não hesitou a dar início aos seus desenhos e, mostrou-se inserida numa conversa na qual Josi contava aos outros o quanto Gabriela havia se interessado por um rapaz que encontraram no caminho.

No sexto encontro, este novo estado de Gabriela se solidifica um pouco mais. A visita dos pais no Natal teria contribuído para esta melhora. É somente nesta 
semana que ela começa a falar sobre seus desenhos, apesar de em todas as outras vezes, ter sido convidada a fazê-lo.

No sétimo encontro, a dificuldade de se adaptar ao abrigo vai ser melhor expressa por Gabriela. A menina começa a desenhar os educadores da casa com formas e cores bizarras, mostra-se muito agitada e falante. No encontro seguinte, ao continuar a sua representação um tanto esquisita dos educadores, pergunto se ela sempre desenha as pessoas assim, ou se são só os educadores. Ela me responde com muita certeza de que são só os educadores. Esses desenhos podem expressar o seu estranhamento ao chegar ao abrigo.

Como percebido no momento diagnóstico, Gabriela oscila instantes de profundo retraimento e uma excitação maníaca. Durante a oficina, a menina deixa mais clara esta oscilação iniciando os encontros muito quieta, com desenhos pequenos, desorganizados e este novo momento em que fala muito, dá risadas exageradas, tem uma postura afetada e seus desenhos dos educadores surgem com muitos membros, olhos grandes e cores fortes. Esse movimento mais expansivo coincide com histórias do envolvimento amoroso de Gabriela com rapazes, fosse um menino que encontrou na rua (relatado por Josi no quinto encontro) ou os adolescentes abrigados (relatado pelos participantes da décimo primeiro encontro). No momento em que Maiara regressa das férias, observamos a retomada do isolamento e da temática inicial dos desenhos: flores flutuantes e nuvens.

A entrada num abrigo esbarra na receptividade que se encontra por parte de quem já está lá. A minha recepção não foi muito calorosa, mas, ao longo de três meses, pude ver esta mesma dinâmica se repetindo. Muitas crianças e adolescentes que chegavam eram alvo de brincadeiras sarcásticas, de apelidos e muitas vezes da indiferença de quem já estava ali. Essa reserva em receber os que chegam, fala de uma organização defensiva daqueles que ficam. $O$ abrigo é fundamentalmente uma instituição temporária (BRASIL, 1990/2005, art. 101, parágrafo único). Mostrar-se muito receptivo, envolver-se afetivamente muito rápido pode se configurar uma ameaça, na medida em que, as crianças e adolescentes não possuem nenhuma previsão de quanto tempo ficará ali. Durante a realização da oficina, vi casos de crianças e adolescentes que se evadiram, foram transferidos para outra cidade, 
regressaram à família, foram adotados... E toda esta instabilidade, para quem fica, é muito dolorosa.

A mesma temática ressurge na última semana com a participação de outros dois adolescentes que nunca haviam participado antes. Leandro tinha comportamento e fama efeminada e por isso era alvo de muitas piadas. Mariana havia chegado ao abrigo há pelo menos um mês, mas os outros participantes alegavam não saber o seu nome e a chamavam de "menina". Tudo isso teve que ser apontado e trabalhado na oficina, como uma tentativa de preservar todos os participantes e o grupo. Paula, uma educadora que participou de alguns encontros, também é alvo neste encontro de brincadeiras preconceituosas em relação à sua religião. Como os participantes não eram constantes, a cada nova chegada, um desafio se fazia e todo o setting devia ser reafirmado.

\section{Os vínculos afetivos que se (re)constroem durante o acolhimento}

De acordo com Bowlby (1985) e outros etólogos, os seres humanos, assim como diversas outras espécies, possuem uma tendência a formar vínculos fortes e persistentes uns com os outros. Sendo esta uma característica comum a todos nós, aonde quer que estejamos, será possível notar um movimento rumo ao estreitamento de laços afetivos.

Seja pelo viés das crianças e adolescentes ou dos funcionários, a relação que se estabelece entre todos os que circulam pela instituição emergiu ao longo dos encontros muito fortemente. Roberto, logo no primeiro encontro já trás à tona algo fundamental.

Em seu primeiro desenho, o educador representa três casas colocadas lado a lado, onde, em cada fachada se lê: "escola", "trabalho" e "abrigo". A casa do meio "trabalho" - é envolvida por um grande coração vermelho e dentro dele se lê "família". Logo abaixo da casa "abrigo" veem-se 12 figuras que representam Roberto e todos os abrigados da casa.

Ao ser inquirido por Josi, sobre o que havia desenhado, ele responde que tinha representado o seu papel no abrigo, como alguém que encaminha a criança e o 
adolescente para a escola, trabalho etc. O papel do cuidador como mediador entre as crianças e suas perspectivas de futuro também foi encontrado por Berger e Gracino (2005), numa pesquisa desenvolvida com dezesseis funcionários de um abrigo.

Roberto acrescenta que seu objetivo como educador era a família. Diante desta colocação, eu que observava a enorme cumplicidade entre Josi e Maiara, assim como entre elas e Roberto, fiquei na dúvida sobre que família ele estaria tratando: a família original que ficara fora ou a família que se formaria no abrigo? Roberto responde a minha pergunta dizendo que claramente estava se referindo à família externa, pois "no abrigo não há família".

No terceiro encontro, Maiara desenha uma árvore de Natal que chama a minha atenção pelos poucos enfeites. Com a proximidade das festas de final de ano, imaginava que o Natal traria consigo muitos significados para as meninas, pois tratase de uma festa familiar e marca as férias como oportunidade de visitar a família. Começo a perguntar sobre o tema e o que surge é uma queixa em relação à forma como o natal é comemorado no abrigo. Josi é quem começa a falar, dizendo que lá, o natal é como um dia qualquer.

Neste dia, Roberto não havia participado desde o começo, chega já no final e percebo que tanto Maiara como Josi querem que ele tome conhecimento do que pensam em relação ao natal do abrigo. Estimuladas por mim, elaboram a queixa do Natal despersonalizado que acontece na casa. Roberto fica um pouco desconcertado com o que ouve, como se não soubesse bem o que fazer. Paula, uma educadora que acompanhou as atividades deste encontro, se propõe a fazer um natal diferente naquele ano. Começa ao final deste encontro: com papéis colorido e propõe que façam uma decoração especial.

Essa organização de tornar o dia natal um dia qualquer esbarra no ideário verbalizado por Roberto, de que no abrigo não há família, e sendo o Natal, na nossa cultura, uma festa familiar, no abrigo não há Natal.

O estabelecimento de vínculos profundos vai além das relações consanguíneas como falam autores já citados (WINNICOTT, 1988/2006; BOWLBY, 1997). Podemos compreender que uma afirmação como a de Roberto reflete a voz da instituição que 
não legitima estas relações mais profundas que foram observadas. Já no primeiro encontro, observamos Roberto, Josi e Maiara muito entrosados e descontraídos, demonstrando grande cumplicidade.

A negação da profundidade do vínculo afetivo que pode se formar no abrigo parece não estar presente em Maiara e Josi, que, desde o início verbalizam se considerarem irmãs. Josi, ao comentar um aspecto bom de morar em abrigo, salienta o convício com as pessoas. Maiara, no mesmo sentido, conta que sentiu muita falta das pessoas do abrigo quando passou um período desacolhida. Essas meninas colocam o valor positivo do abrigo nas relações humanas, que, provavelmente são mais saudáveis do que aquelas que possuíam na família de origem. E isso parece não Ihes provocar um conflito. Como veremos adiante, para elas, a dificuldade está em como administrar esse sentimento numa instituição de passagem. Torna-se difícil se vincular a alguém que dali a pouco pode não estar mais acessível.

A separação entre família e abrigo já se dilui quando Josi conta na primeira semana que um dos meninos da casa está sendo adotado por um ex educador que ali trabalhou. Esta fantasia de fazer parte efetivamente da família de um dos educadores fica mais clara quando nota-se o interesse dos abrigados em conhecer a vida pessoal do cuidador. Isso acontece tanto com Roberto como com Paula que, no oitavo encontro se desenha com o filho. Esse desenho gera uma série de comentários por parte de Daniela que quer sabe se ela conhece o filho de Paula, se Paula já o levou alguma vez ao abrigo... Diante destas perguntas, todos ficam muito atentos às respostas. O mesmo se dá quando, Lucas - outro adolescente que só participa durante as férias - menciona que conhece o irmão de Roberto. Pela reação do grupo, parece que, ter qualquer informação da vida pessoal dos cuidadores é algo valorizado e desejado.

Esta cisão que Roberto apresenta, vai se enfraquecer ainda mais no segundo encontro. No primeiro desenho, Roberto fez questão de representar cada uma das crianças e adolescentes abrigados e ele mesmo. Quando comparamos com o seu segundo desenho, vemos uma cena semelhante: duas casas conjugadas, ele em meio a diversas crianças. Mas explica que, desta vez são seus sobrinhos. (Um dado interessante que nos ajuda a acompanhar os fios que tecem estas fantasias é o fato 
de, no abrigo, as crianças terem o hábito de chamá-lo de "tio Rô", o que não foi observado em relação aos outros educadores.).

Ele nos conta que, enquanto, durante a semana, está cercado pelas crianças do abrigo, aos finais de semana, está na companhia dos sobrinhos. Em determinado momento pergunto se ele tem filhos. Roberto responde que não e Josi completa dizendo: "Mas também não precisa, né, tio Rô, você já tem a gente." Ele ri e completa com o quanto as crianças do abrigo o absorvem com suas demandas. Esse, talvez, seja o único momento em que se mostra mais aberto em relação a este assunto e consegue falar espontaneamente. Conta que não consegue se afastar do abrigo nem mesmo nas suas folgas e férias. Precisa ligar diariamente ou chega a ir pessoalmente averiguar se tudo está bem.

O próprio educador nos dá pistas para entender o motivo dessa cisão. $\mathrm{Na}$ primeira entrevista individual, Roberto nos conta a sua história. Antes, trabalhava em outro abrigo, onde não era permitido ter qualquer contato afetivo com os abrigados. A equipe dirigente reafirmava constantemente a necessidade do afastamento. Com a mudança da direção, os procedimentos foram alterados: o contato era incentivado, desde que não comprometesse a autoridade.

A experiência do abrigo de onde Josi e Maiara vieram é muito forte também. Lá, os educadores faziam vistas grossas para o consumo de drogas que ocorria dentro da instituição e não tinham qualquer autoridade. Como este exemplo, havia outros nos quais a proximidade afetiva irrestrita e o descomprometimento com a função de educador havia sido extremamente prejudicial. Nesta primeira entrevista, Roberto diz que não pode ser muito carinhoso com as crianças e adolescentes, porque algumas pessoas poderiam "maldar" (sic). Em outros termos, ele teme que a sua demonstração de afeto seja interpretada como uma relação que não convém e que o coloca num lugar de repetidor da violência.

A delicadeza na determinação do limite na relação entre educadores e abrigados também foi abordado por Dottori et al. (2008). Ao analisarem o discurso de educadores numa casa abrigo, destacaram falas carregadas de afetos positivos em relação às crianças. Ao mesmo tempo, notou-se que o diálogo dos educadores com os abrigados era confundido com permissividade ou autoritarismo, muito semelhante 
ao conflito trazido por Roberto e observado no comportamento de outros cuidadores da casa.

O medo de ultrapassar o limite e se tornar muito permissivo, pode conduzir os educadores a terem um contato muito distanciado com os abrigados. Josi, em um dos encontros reclama que, existiam certos cuidadores na casa, que nem sequer davam "bom dia" quando chegavam. O risco que se corre é o de transformar o abrigo num ambiente marcado pela despersonalização, impessoalidade, inexistência de vínculos significativos, reproduzindo, assim, a lógica da exclusão e do abandono (DOTTORI et al., 2008).

Após a entrevista final com a coordenadora da instituição, outro complicador desta questão veio à tona: a afinidade pessoal do educador com a função que desempenha. Por se tratar de um abrigo municipal, os cargos são preenchidos por concurso público, instrumento incapaz de selecionar de forma efetiva pessoas que de fato se identifiquem com a tarefa de cuidador. Martinez (2006) observa a mesma dificuldade na instituição (também municipal) na qual realizou sua pesquisa. Menciona uma educadora que não via a hora de ser transferida de cargo, pois prestara o concurso público achando que desempenharia outra função. Destaca a fala: "Quando eu entrei aqui, fui muito sincera com a coordenadora. Disse que não gosto muito de criança, não gosto dessa pegação (SIC), mas as outras [educadoras] acabam ficando mais com eles e eu fico responsável pela parte da comida que é o que eu gosto de fazer. Mas logo, logo eu vou sair daqui." (MARTINEZ, 2006:115).

Esse obstáculo gera consequências tanto no sentido de destacar para esta função uma pessoa que não tem o menor apreço por crianças e pelo cuidado como de impedir uma aproximação mais consistente de um funcionário responsável por outra tarefa como a limpeza, por exemplo. Isso acontece no caso de Paula, que fora contratada para desempenhar uma função operacional, mas que possuía grande sensibilidade no trato com as crianças e adolescentes.

A divisão entre um funcionário que assume um cargo operacional e um educador já havia sido salientada na pesquisa AASPTJ-SP; NCA-PUC-SP; SAS; FUNDAÇÃO ORSA (2003:134). De acordo com os dados levantados, funcionário que assume as atividades rotineiras do abrigo como lavar, cozinhar, arrumar, embora possa intervir 
na educação da população abrigada, nem sempre tem autorização para assumir o papel explícito de educador.

A questão da contratação de funcionários que não possuem afinidade com o cuidado de crianças e adolescentes nos levam a problematizar a falta de formação técnica como destacado por Martinez (2006). Galheigo (2003) reafirma a necessidade premente de projetos de profissionalização, qualificação e capacitação dos cuidadores e gestores. Para isto, acrescenta a urgência no desenvolvimento de uma política que garanta seleção criteriosa, formação continuada e supervisão. Além disto, destaca-se a necessidade de um espaço de interlocução para estes funcionários, onde as experiências no trato com os abrigados pudessem ter voz para serem trabalhadas e amenizarem-se os conflitos como salientado por Dottori et al. (2008). Desta forma, a atuação como educadores seria mais coerente com o discurso institucional e legal assim como com os sentimentos pessoais.

Ao longo da oficina, Roberto vai demonstrando o quanto não se sente à vontade com demonstrações explícitas de afeto. Nos sétimo e oitavo encontros, Daniela fez um coração que decide dar para Roberto. Ele está presente no momento em que a menina fala tudo isso, mas mostra-se quase estático, não deixando transparecer qualquer reação positiva diante das palavras da adolescente. No nono encontro, a mesma adolescente desenha uma bandeira com uma estrela no centro que simbolizava Roberto, e diz de pé, na frente de todos, que ele era um irmão, um pai para ela, pois cuidava dela. Roberto demonstra desconforto e é incapaz de falar qualquer coisa que acolha este o gesto de Daniela.

Roberto não participou de mais nenhuma encontro dali em diante e nem mesmo mostrou-se disponível para a devolutiva individual. Sempre alegava estar muito atarefado e se desculpava sempre que me encontrava. Tinoco (2007) em seu mestrado propôs um grupo educativo junto aos cuidadores de um abrigo. Chamou a atenção da autora a ausência dos cuidadores diretos das crianças nos encontros. Tinoco elenca as principais justificativas que versaram sobre a dificuldade de deixar suas tarefas para participarem da atividade. A autora chega à conclusão da importância de auxiliar os educadores a lidar com seus próprios sentimentos em relação às crianças e adolescentes acolhidos. Somente a consciência do quanto são 
mobilizados pelos abrigados permitirá sair de imobilidade e cuidar melhor de si e do outro.

O cotidiano exige tanto de um cuidador que é importante que consigam ser eles mesmos para que tudo se dê de forma natural e coerente como coloca Winnicott (1987/1999:76). Somente desta forma, é possível lidar com toda sorte de situações que ocorrem numa instituição deste tipo sem perder o próprio self e propiciando o amadurecimento dos abrigados.

Como se pode ver, a questão da demonstração afetiva e seus limites não é clara. Porém, esta problemática não se restringe apenas a este abrigo, ou a estes educadores. Quando retomamos a especificação da função do educador contida na pesquisa "Por uma política de abrigos em defesa de direitos das crianças e dos adolescentes da cidade de São Paulo" (AASPTJ-SP; NCA-PUC-SP; SAS; FUNDAÇÃO ORSA, 2003:134), encontramos os seguintes dizeres: "O educador seria o profissional com função relacionada aos cuidados diretos que envolvem o processo socioeducativo da criança ou do adolescente, (orientar brincadeiras, normas de convivência, acompanhá-los nas atividades, etc.)". A função dos educadores não está especificada em nenhum documento oficial, mesmo porque é difícil regulamentar o contato humano genuíno. Winnicott (1987/1999:201) já havia teorizado que, para se fazer a coisa certa por uma criança não se pode prescrever tudo, nem, tão pouco promulgar uma lei ou instalar diretrizes administrativas. Por outro lado, é notável que não haja qualquer menção à função afetiva que tais profissionais desempenham e que é tão fundamental quanto as tarefas de organização diária.

A importância deste aspecto reside no fato afirmado por Careta (2006) e Rotondaro (2005) de que as crianças consigam desenvolver vínculos saudáveis nos abrigos a partir de condições internas preservadas. Para isso, são necessários esforços que visem à melhor compreensão dos funcionários acerca da doação emocional que Ihes será exigida (WINNICOTT, 1987/1999) para que consigam estabelecer vínculos saudáveis para ambos os lados.

É necessário cuidar das relações afetivas que se dão no abrigo, pois elas, assim como o incentivo ao estudo, também instrumentalizam a criança e o adolescente 
para a vida subsequente ao período de acolhimento. Como coloca Bowlby (1985), o padrão de relação afetiva que se estabelece com figuras de apego de referência se tornam modelos para as relações futuras, de modo que é importante que estes vínculos se deem de forma espontânea e verdadeira. Esta figura de referência pode ser tanto um educador, como a diretora do abrigo, a psicóloga, e - por que não outras crianças e adolescentes abrigados, como veremos a seguir.

Josi e Maiara estão abrigadas juntas de 2007 e a relação das duas é intensa no que se refere à cumplicidade e ao carinho. $\mathrm{E}$ isto fica evidente desde o primeiro encontro. Este assunto pôde emergir com mais propriedade após a ida de Maiara para a casa do irmão em virtude das férias. Na sexta semana, já é possível perceber uma mudança de comportamento bastante drástica em Josi: mostra-se desanimada, calada, mal humorada. Desenha o que chama: "o buraco negro do tédio" e se retira do espaço da oficina.

$\mathrm{Na}$ semana seguinte parece ainda pior: não demonstrou iniciativa sequer para escolher uma folha de papel e escreveu numa folha preta dizeres como: "tédio!", "medo", "insegurança", "ódio", "raiva", "pessoas chatas", "isolar", "todos felizes e eu não", "chorar", "paciência", "o ódio corre em minha veia". Perguntei se podia ler e enquanto o fazia em voz baixa, seus olhos se encherem de lágrimas. Apesar das minhas tentativas de saber o que estava acontecendo, mesmo em particular, a menina se recusou a falar. Pela proximidade que ela e Maiara demonstraram em todos os encontros anteriores, foi aventada a hipótese de que Josi devia estar sentindo falta da amiga. Quando pergunto se elas estão se falando durante as férias, Josi responde que não podem se falar e nem visitar a amiga. Não foi averiguado com a direção do abrigo se, de fato, havia uma proibição neste sentido, mas o importante é o sentimento de Josi em ter Maiara inacessível.

Este comportamento de Josi parece ter um papel de atrair para si a preocupação de todos ao redor, inclusive a minha. Daniela expressa um comportamento acolhedor em relação a ela, que mesmo muito fechada em sua dor, consegue ser tocada por esta solidariedade. No sétimo encontro, ela identifica Josi com uma árvore que desenhou, mas faz questão de dizer que se esqueceu dos frutos. Essa associação nos mostra a imagem positiva que Daniela fazia de Josi. Diz que Josi é sua amiga e esta última que se encontrava muito emburrada, até esboça um sorriso. 
Neste mesmo encontro, Daniela acolhe o sofrimento da amiga, quando, ao ouvir o que escreveu em seu desenho, fala dos momentos em que tem raiva de falsas amigas. Josi ouve e acena positivamente, como se Daniela tivesse acertado o que a fazia sofrer. Paula e Roberto também se mostram muito preocupados com Josi. A educadora me procura pessoalmente para pedir sugestões de como acessar a jovem. Falo com Paula sobre a impressão de que Josi sentia falta de Maiara.

É interessante a mobilização que vemos de todos em torno do "mau humor" de Josi. Na entrevista inicial com Roberto e nas produções gráficas da adolescente, reações reativas e rebeldes já tinham sido expressas como uma forma de Josi comunicar o que estava sentindo. Durante os encontros, o "mau humor" surgia de fato para comunicar sentimentos profundos e angustiados da adolescente que parece ter até uma dificuldade em nomeá-los na medida em que usa nomes genéricos como "mau humor" e "tédio". Podemos pensar que seriam manifestações depressivas da adolescente. Quando observamos todo o seu comportamento, vemos que há algo a mais por trás do que estes termos designam.

Na semana seguinte, encontro Josi completamente mudada: sorridente, radiante como nunca. Procura me ajudar a organizar o início e final da atividade. Antes de ir embora, Paula me procura e confirma que a saudades de Maiara tinha de fato mexido com Josi. Depois de conseguir nomear este sentimento para a adolescente, Josi chega a pedir que Paula Ihe faça companhia enquanto assistia televisão, o que é um comportamento raro na menina, que se mostra sempre muito arredia. Todo o contexto da oficina, desde a expressão dos sentimentos no desenho, o acolhimento de Daniela e dos educadores, pôde facilitar a tradução da angústia pela separação de Maiara.

Nesta semana, Josi desenha uma casa "Antiguinha, com piso de madeira, roxa por fora e clarinha por dentro" e quando pergunto quem morará com ela, responde: "Meu irmão e Maiara. Já falei para ela falar com a mãe dela. Se ela deixar..." Em outro desenho escreve: "Volta às aulas" e de forma quase ilegível: "Saudades da Maiarinha". Todo esse movimento de Josi mostra o quanto é importante se nomear o que se sente. A saudade existe, mas a angústia de se estar à mercê de algo ruim, inominável se foi. Desta forma a esperança no futuro e no desacolhimento pôde se restabelecer. 
O desacolhimento compulsório de Josi ao completar 18 anos vai afastá-la destas referências afetivas tão importantes para ela. Na primeira entrevista, a adolescente nos conta que seguiu o irmão quando este quis ser adotado por uma família mesmo não tendo gostado de outra experiência de inserção em família substituta. Esse gesto de Josi mostra seu esforço em não romper o vínculo com o irmão, não esquecendo que ela já tivera outros irmãos adotados com os quais não tem mais contato. A dor da separação entre irmãos é observada por Martinez (2006). A autora aborda este tema ao entrevistar um rapaz abrigado cujos dois irmãos mais velhos já tinham completado 18 anos e ido embora do abrigo. Quando saíram, se envolveram com o tráfico de drogas e chegaram a ser presos. Por estes motivos, a coordenação do abrigo não permitia o contato entre os egressos e o irmão ainda abrigado. Este rapaz relata para a pesquisadora o seu sofrimento ao não ter mais contato com seus irmãos, não saber se estão vivos. Assim como Josi, o irmão abrigado com ela é a única referência da família que um dia existiu.

Tornando esta discussão ainda mais complexa existe a ligação afetiva da adolescente com Maiara e Daniela, abrigadas há anos juntas e que se identificam como irmãs. Podemos antever o sofrimento de Josi frente a estes afastamentos na ocasião das férias quando Maiara vai para a casa do irmão e as duas perdem o contato por um mês. Rentes e Tardivo (2012) trataram deste tema ao apresentar a produção de desenho estória com tema de uma menina de 17 anos. No desenho, a adolescente representava o passado, o presente e o futuro. Conta o quanto considerava duas amigas também abrigadas e os funcionários da instituição como sua família. A dor da separação foi representada por um caixão com flores no desenho onde deveria expor o que aconteceria depois do abrigo. No caso relatado por Martinez (2006) a perspectiva do desacolhimento e da consequente perda de contato com as figuras de referência geravam um profundo sentimento de insegurança e desesperança em relação ao futuro. Estes pontos surgem como consequência do desacolhimento compulsório. Os adolescentes não deixam o abrigo quando estão preparados, mas porque a lei os obriga. Esta obrigatoriedade afeta não só a eles como à equipe técnica, que no caso de Josi, mostrava certa apreensão e ansiedade em relação a este momento, tentado empreender todos os esforços para preparar a adolescente o quanto antes. 
No contexto da institucionalização, as relações de afeto e cuidado desempenhadas pelos irmãos e pelos pares assumem um significado específico e muito importante para o desenvolvimento emocional e social, como salientou Alexandre e Vieira (2004). Os autores afirmam que, após a separação com a família, um amigo do abrigo pode se configurar como uma figura de apego, e acrescentamos também os próprios funcionários, que se constituem como referências, como é o caso de Roberto.

Considerando que o estreitamento de laços entre seres humanos é inevitável, a instituição abrigo de modo geral, considerando a formação deste tipo de vínculo entre as crianças e adolescentes como legítimo e benéfico, poderia adotar medidas para que estes rompimentos fossem menos dolorosos, como incentivar o contato através de telefonemas, visitas eventuais, passeios etc. Além disto, o incentivo aos laços no abrigo durante a institucionalização permitiria a ampliação desse tipo de gesto como o de Daniela que acolhe o sofrimento de Josi. O que observamos, de modo geral, é o contrário: relacionamentos hostis de intensa competição entre os abrigados como vemos no décimo segundo encontro. $\mathrm{O}$ desacolhimento não deveria significar necessariamente o banimento de pessoas que foram importantes num determinado momento de vida.

O nono encontro marca o retorno de Maiara recebida com muita alegria por Josi e seu irmão que participava pela primeira vez. Gabriela que havia se aproximado muito de Josi na ausência de Maiara, volta a ficar retraída com o regresso desta última. Seus desenhos recuperam a temática das nuvens e flores sem caule. Volta a ficar calada e observa muito atentamente as trocas afetivas do trio. Esta é a última participação de Gabriela.

Josi deposita tanto nesta relação com Maiara que, para ela, se torna difícil aceitar a reparação quando Maiara a decepciona. No décimo encontro as duas não estão se falando. Diante disto questiono o que está acontecendo. Maiara conta que pegou a maquiagem de Josi sem pedir permissão e acabou quebrando. Para Josi o mais grave foi o fato de Maiara ter mentido sobre a autoria do estrago. Disse várias vezes que não gostava de mentiras.

Procuro dizer que há coisas que se estragam, mas que tem conserto. Josi se mostra muito rígida e dá o exemplo de um cristal que se quebrou e nunca mais será 
o mesmo. Mesmo quando Maiara lhe pede desculpas na frente de todos, Josi desqualifica o pedido, dizendo que foi apenas porque eu havia sugerido. Gabriela também havia estragado um brinco de Josi e talvez a hostilidade desta última tenha deixado Gabriela afastada das atividades. Esse ressentimento da adolescente persiste na décima primeira semana. Diante da postura inflexível da adolescente sobre a recusa da proposta do desenho coletivo, Maiara e Gabriela se excluem da atividade. Para Josi, é tão difícil perdoar as falhas cometidas por aqueles de quem gosta que acaba sendo implacável no julgamento. Assim, afasta as figuras amadas como acontece com sua mãe.

No penúltimo encontro, todos os participantes saem no meio da atividade, pois tinham que fazer exames médicos para a aula de natação. Ficamos apenas eu e Josi e conversamos enquanto desenhávamos. Aproveito a oportunidade e volto ao conflito com as meninas. Fala da falta de espaço que sente no abrigo, até mesmo para guardar as suas coisas num lugar que ninguém mexa. Essa falta de liberdade não se delimita à questão espacial. Diz que não se abre com ninguém, mas sente-se mais a vontade na escola, onde não se sente pressionada a ser um modelo de maturidade nem é julgada pelas coisas que faz. Relata que ninguém a conhece de verdade.

Então caminha para a ansiedade e preocupação que sente com a perspectiva do desacolhimento (já estava com 16 anos). Na sua fala fica implícito o medo do que enfrentará e de se ver sem as figuras de referência da instituição. Martinez (2006) levantou alguns pontos acerca do desacolhimento a partir de entrevistas com jovens prestes a saírem da instituição. A transformação do abrigo como um local de referência com o qual o adolescente poderá contar se precisar foi um dos pontos abordados pela pesquisadora. Outro aspecto comum entre Josi e os adolescentes da pesquisa de Martinez foi o sofrimento de se ver afastada das figuras de referência e da insegurança oriunda da responsabilidade crescente.

Percebemos aqui a ambivalência da adolescente em relação a uma liberdade tão ambicionada e a consequente responsabilidade em ter que cuidar de si e do irmão, além de se ver longe daqueles que the deram suporte até então. Josi se queixa do quanto não pode sequer visitar uma colega de escola, mas na devolutiva para a 
equipe técnica vemos que, pelo contrário, a adolescente é incentivada a sair, mas recusa-se.

Em função deste momento tão delicado, havia a preocupação da psicóloga do abrigo em reaproximar Josi da mãe, o que não estava sendo fácil. Josi, no Teste das Fábulas já havia exposto o quanto não consegue definir o que sente em relação a mãe, de modo que não a vê como uma figura em quem pode confiar. Martinez (2006) também ressalta que no momento do desacolhimento a reaproximação com as figuras parentais pode ser muito difícil dependendo das circunstâncias. Na primeira entrevista, Roberto já havia nos contado o quanto o contado de Josi e a mãe é delicado. A adolescente não permite qualquer aproximação, limitando-se que querer ver a mãe se ela trouxer presentes.

$\mathrm{Na}$ fábula VI, Josi havia comunicado seu receio diante do crescimento irreversível. O amadurecimento para ela era acompanhado de uma responsabilidade muito grande na medida em que, uma vez fora da instituição deveria cuidar muito bem de si e do irmão. Quando, no primeiro encontro nos conta sobre o término de seu namoro, dá a entender que o que estragou tudo foi a iniciativa da coordenadora em mostrar a Josi que somente ela poderia decidir o que seria melhor para si. Esse gesto da coordenadora devolve para a jovem a responsabilidade pelas suas escolhas e pela sua vida.

A sua produção no Desenho da Pessoa na Chuva se torna mais clara neste contexto. Desenhou uma jovem com a mesma idade do que ela, com uma fisionomia brava empunhando um guarda chuva que parece empurrar as nuvens acima da cabeça da personagem. O guarda chuva possui um tamanho adequado, mas uma gota de chuva escorre do olho direito da figura. A pressão vivida diante da perspectiva do desacolhimento faz com que a menina se sinta muito pressionada, angustiada e sofrida.

A dificuldade de Josi em elaborar o motivo que a levou ao abrigo assim como poder aceitar a aproximação da mãe nos faz pensar que o acolhimento não implica na dissolução imediata e completa dos vínculos familiares. Durante o período de institucionalização, o vínculo afetivo com as figuras parentais, que de alguma forma, falharam na função protetora destas crianças e adolescentes, é revisto, reconstruído e reelaborado. 
No caso de Josi, a mãe tentava se aproximar dos filhos, ao passo que era rejeitada pela filha que a culpava pelo acolhimento e não aceitava suas investidas. No teste das Fábulas, Josi já havia exposto sua falta de confiança na mãe. Esta, por sua vez, não possuía condições para desabrigar os filhos, sentindo-se suficientemente culpada a ponto de se submeter às condições da filha, que só lhe telefonava para lhe pedir presentes. E a mãe lhes dava tudo o que podia.

Quando a oficina acabou, a equipe do abrigo trabalhava junto à mãe, para que ela não cedesse a esta relação comercial. $O$ abrigo trabalhava sobre o estreitamento do vínculo entre mãe e filha, devido à aproximação do desacolhimento da jovem pela maioridade civil. A mãe era a única pessoa que Josi tinha fora do abrigo e podia ser uma referência afetiva se a menina permitisse. Observamos que este abrigo possuía uma atenção muito sensível ao desacolhimento de Josi, ajudando na busca de emprego, no incentivo para a que a adolescente aprendesse a circular pela cidade, no reestabelecimento do contato com mãe e no estímulo a se interessar e desempenhar bem nas tarefas de cuidado da casa.

Essa função de intermediar o contato do abrigado com sua família constitui-se como uma tarefa muito complicada, uma vez que, como nos disse Winnicott (1987/1999:49), quando uma criança regressa ao lar após ter ficado um tempo considerável longe, os lugares ocupados podem ter sofrido mudanças que exige uma retomada da construção das relações e que podem sofrer diversas frustrações ao longo deste caminho. Além disso, Bowlby (1997: 31) nos alerta que, o comportamento imaturo e ansioso da criança ao voltar para casa pode despertar na mãe reações de repreensão e punições pelo mau comportamento, o que gera um círculo vicioso com novas birras e consequente prejuízo à relação. Silva, Leoncio e Tardivo (2007) ressaltaram o quanto é importante que a instituição desenvolva um trabalho junto à família para que seja recuperada a capacidade de cuidado.

Um acompanhamento técnico após o desacolhimento se faz imprescindível até mesmo para evitar que a fantasia de um lar idealizado, ou seja, que satisfaria todas as necessidades, se interponha ao contato com a realidade, de modo que prejudicaria a descoberta das vantagens e qualidades do lar real (WINNICOTT, 1987/1999). Baseando-se na experiência de Leoncio e Tardivo (2007) e Paschoaletti, Careta e Motta (2008), a assistência psicológica realizada junto aos 
pais pôde ajudar no reestabelecimento do vínculo rompido. Nos dois casos, as pesquisadoras apontam para a importância do holding e da maternagem do terapeuta em relação à família para que se construa condições adequadas ao regresso da criança.

Um movimento semelhante se observou na mudança do abrigo antigo para o atual. Nos primeiros encontros, quando Josi e Maiara mencionam o abrigo antigo, este surge muito idealizado como um ambiente que proporcionava uma liberdade praticamente irrestrita. A partir dos relatos, vemos que a adaptação ao novo abrigo sofreu diversos ataques pela dificuldade em aceitar as falhas no cuidado ocorridas no abrigo anterior que eram encaradas como garantia de livre expressão. Essa imagem idealizada dificultou a vinculação à nova instituição, que por sua vez, trabalhou arduamente para ser encarada como um espaço que proporcionava um cuidado mais efetivo, mesmo que não permitisse uma liberdade como aquela desejada por Josi e Maiara.

No último contato que fiz com o abrigo, mais ou menos 4 meses depois do término do meu trabalho, fiquei sabendo que Josi e o irmão já estavam passando os finais de semana com a mãe, o que, no período da oficina era algo inimaginável.

A tomada de consciência da falha familiar é muito dolorosa. Guilherme, ao participar pela primeira vez das atividades no quarto encontro projeta seu sofrimento num desenho realizado por Josi. Ela faz um coração com cicatrizes de onde escorrem gotas de sangue e está cercado por caveiras e corações menores igualmente feridos. Ao ver este desenho digo que o coração deve estar sofrendo muito e me pergunto o porquê. O menino responde que a causa de tamanha dor foi que a mãe machucou o coração, encravando um osso na testa da caveira, porque Josi tinha feito bagunça.

Antes do acolhimento, Guilherme era bem cuidado por uma moça que não era sua mãe em outra cidade do interior paulista. Veio morar com a mãe, que não conseguiu dar conta de seu papel e ele foi abrigado. Desde o primeiro momento, o menino fala muito desta moça, do quanto quer voltar a morar com ela e do quanto ela está extremamente ansiosa por tê-lo de volta. A própria psicóloga do abrigo conta o quanto esta mulher liga insistentemente para o abrigo, aflita para descobrir o 
andar do processo, pois sentia muita falta do menino. As burocracias judiciais postergaram seu retorno por meses, que corresponderam exatamente à duração da oficina A cada semana, ele repete que irá embora no dia seguinte. Até que, finalmente, no dia que vou dar a devolutiva, encontro-o muito ansioso, pois na manhã seguinte voltaria para casa. Ele que sempre se mostrou muito agitado e irreverente, se mostra mais calmo e de despede com os olhos apreensivos e um grande abraço, dizendo que não se esquecerá de mim.

Apesar de possuir uma pessoa motivada e envolvida afetivamente com seus cuidados, Guilherme mostra, ao falar do desenho de Josi, o seu sofrimento pelo fato da mãe não ter conseguido cuidar dele.

Maiara, de todos, era a que tinha uma situação familiar mais definida. Apesar de a mãe fazer uso abusivo de álcool e não demonstrar, apesar de fazer tratamento, condições de cuidar da filha, a menina possuía uma irmão mais velho, casado, que vinha fazendo o possível para retirá-la do abrigo. Estava caminhando muito bem.

A equipe da instituição tem um papel fundamental nessa elaboração das relações familiares. O exemplo mais evidente é o caso de Gabriela. Como mencionado anteriormente, a menina fora abrigada por uma denúncia anônima que trouxe à tona um relacionamento amoroso/sexual dela com um rapaz de 23 anos com o consentimento da sua família. No terceiro encontro, quando converso em particular com ela, percebo uma dificuldade profunda em conseguir ver a falha familiar no seu caso a ponto de negar o motivo do acolhimento quando fala que não sabe porque está ali e só deseja voltar para casa.

Durante o período da oficina vemos um movimento pessoal em se apropriar destes aspectos tão dolorosos. Em conversas particulares com a psicóloga do abrigo, a menina começa a relatar fatos da vida familiar onde expõe uma dinâmica doentia e que Ihe traz questionamentos, por exemplo, acerca da natureza da relação que sua mãe tinha com seu "namorado". Em outro momento, queixa-se do quanto seu irmão não fez nada para lhe proteger.

Durante o período de acolhimento, além de toda a problemática dos vínculos que estão se formando entre as pessoas que circulam pela instituição, existe uma reestruturação da relação familiar e cada criança vai viver esse processo de uma 
forma diferente. A sensibilidade da psicóloga e diretora deste abrigo foi indispensável para auxiliar estas crianças e adolescentes a elaborar estes vínculos tão machucados e complexos. Esse resgate deve ser feito com cuidado, respeitando o tempo e limite de cada jovem e da família.

A relação das meninas comigo também se alterou com o desenvolvimento do trabalho. Todos sabiam que ele tinha um prazo para se realizar, o que não impediu que, de alguma forma nos vinculássemos. A reserva e desconfiança sentidas num primeiro momento foram diluídas com o desenrolar da atividade. Evidenciando a construção do vínculo.

No quarto encontro, o esforço de Josi, Maiara e Guilherme em providenciar materiais improvisados para a realização da atividade é compreendida como expressão do quanto apreciavam aquele espaço. Como era feriado municipal e eu não sabia disto, deixei claro que eles não precisavam participar, que voltaria na semana seguinte, mas foram muito acolhedores. No mesmo sentido, quando converso individualmente com Josi, ela pôde valorizar a minha presença e verbalizar que havia sido bom conversar com alguém. Esta questão da vinculação comigo fica indiscutível no último encontro. A atividade extrapolou o tempo determinado à revelia das minhas tentativas em encerrá-la. Até brinquei com as meninas, dizendo que se demorassem um pouco mais, teria que ficar para o jantar, e para minha surpresa elas comemoraram. Do primeiro contato, ao último, fica evidente o envolvimento afetivo e a dificuldade da despedida, que num abrigo, é sempre constante, assim como a chegada.

\section{O enquadre da Oficina como promovedor de experiências mutativas}

A Oficina Expressiva de Desenho e Pintura constituiu-se como um espaço de respeito e acolhimento da condição existencial de cada participante Herrmann (2004). Baseou-se na leitura que Bleger (1963/1984) fez de Politzer (1928/1975) de que toda conduta humana é dotada de sentido e para compreendê-las nos apoiamos teoria winnicottiana. 
A produção artística interessou-nos como veículo que permitiu a aproximação de fenômenos humanos e a emergência de gestos criativos, geradores de experiências mutativas, da mesma forma como ocorre no ato brincar (WINNICOTT, 1971/1975). Para isto, a oficina se organizou de modo a oferecer uma sustentação emocional capaz de auxiliar cada participante a integrar aspectos indiferenciados do self rumo a uma experiência mais autêntica como sujeitos (AIELLO-VAISBERG; AMBROSIO, 2007).

Para promover tal intento, o enquadre se fundamentou em algumas bases como: o uso de materiais gráficos e pictóricos; determinação de dia e hora para o desenvolvimento da Oficina; enfoque grupal; a participação não obrigatória e aberta a quem tivesse interessado; o sigilo e respeito para o que ocorria no espaço das atividades; a proposta desenhos baseados num tema livre (com exceção do primeiro encontro). Todos estes pontos formaram uma rede sustentadora das experiências desencadeadas pelos desenhos e pinturas e pelo encontro humano verdadeiro entre os participantes em si e deles com a terapeuta

A escolha por uma materialidade simples e conhecida dos participantes funcionou como um facilitador do contato e atenuador da ansiedade. Além de não se configurar como uma nova variável na análise posterior dos fenômenos que ocorreram. Além disto, como mencionado na apresentação deste trabalho, o desenho e a pintura configuram-se como expressões artísticas com as quais a pesquisadora tem afinidade.

Compartilhando da noção de que um desenho ou uma pintura são expressões subjetivas, que resultam numa síntese pessoal (TARDIVO, 2007), trabalhamos três momentos do desenho. No primeiro deles, utilizamos propostas dirigidas na ocasião do psicodiagnóstico que se valeu do Desenho da Figura Humana e do Desenho da Pessoa na Chuva como instrumentos para a apreensão de aspectos subjetivos de Maiara, Josi e Gabriela. Entendendo o DFH a partir das elaborações de Machover (1949), a representação da figura humana expõe a noção internalizada de si e dos outros. Acrescido, ainda, da especificidade da chuva, o desenho destas meninas nos mostrou como se posicionavam diante das tensões do mundo, que naturalmente esbarravam na condição oriunda da institucionalização. 
As informações obtidas a partir destas produções gráficas, complementadas pelo Teste das Fábulas, pela entrevista e pelos inventários (IFVD e CDI) foram reiteradas num segundo momento em que o desenho foi empregado neste trabalho. Nos encontros, a proposta do desenho livre procurou elevar à máxima potência a capacidade da expressão ativa fundamentada no caráter formlessness (WINNICOTT, 1945/2000) da materialidade escolhida. Se num primeiro contato, a definição do campo do desenho teve como objetivo angariar dados sobre a dinâmica psíquica de cada menina, na etapa seguinte, de posse destas primeiras informações, a Oficina pode transcorrer sob um olhar atento da psicóloga que acompanhou a elaboração de aspectos aventados desde o contato inicial. O desenvolvimento dos desenhos de um encontro a outro nos mostrou o quanto a Oficina foi legitimada como um espaço no qual se mostrar espontaneamente é possível (AIELLO-VAISBERG, 2004).

Josi se apropriou de uma maneira bastante particular da natureza dos materiais usados quando associa as cores das tintas e das folhas de papel ao seu estado de ânimo. Este gesto pessoal da adolescente evidenciou o quanto a materialidade mais simples e trivial pode ser investida de sentido, gerando uma comunicação espontânea e criativa. Para que isto ocorra, foi fundamental a escolha de uma materialidade detentora do caráter formlessness, proposto por Winnicott (2000 [1945]), ou seja, um material que pudesse ser manuseado criativamente e se adequasse às necessidades existenciais do sujeito.

Numa terceira e última etapa, a representação gráfica dirigida, através de uma nova proposição do Desenho da Pessoa na Chuva, procurou investigar uma mudança de posição das participantes em relação às tensões e seus recursos próprios de defesa para lidar com elas. Apesar de se sugerir que a reaplicação de instrumentos projetivos se dê num intervalo mínimo de seis meses, observamos uma alteração no desenho. Associando-se o caminho percorrido na Oficina com tais alterações no Desenho da Pessoa na Chuva, observou-se um movimento rumo a uma maior integração em relação aos conflitos e o seu enfrentamento.

Nestes três tempos em que o desenho foi utilizado, o caráter diagnóstico e o caráter interventivo se alternaram num fluxo constante entre apreensão e elaboração. 
Outra faceta do enquadre extremamente sustentadora para a construção de experiência mutativa ao longo da Oficina foi a manutenção da constância no que se referia ao dia e hora da realização das atividades. Além disto, igualmente fundamental foi a explicitação da duração dos encontros (12 semanas). Dado o contexto de uma instituição de passagem como o abrigo, na qual a inconstância e a imprevisibilidade fazem parte da rotina, proporcionar um espaço estável nestes quesitos foi organizador para os participantes. Assim, foi proporcionado um espaço onde não se repetiram incertezas e rompimentos abruptos de vínculo.

Neste momento, vale relembrar a fala de Lucas no oitavo encontro quando chego um pouco atrasada. Ao me ver chegar diz textualmente: "Você está demitida!". Essa verbalização do adolescente permite supor o grau de ansiedade despertado pelo rompimento da estrutura do enquadre. Sentimento este tão intenso a ponto de fazêlo me esperar no portão e me receber com esta frase tão forte. Winnicott (1988/2006) já havia mencionado as falhas que podem se dar no cuidado e o quanto elas podem afetar o sujeito em maior ou menor grau. $O$ próprio autor salienta o quanto estes episódios podem ser construtivos desde que ocorram num momento em que a criança já possui recursos para lidar com eles. A segurança proporcionada pelo cuidado prévio adequado é um dos fatores que auxilia a criança a se instrumentalizar para lidar com as falhas ambientais. Diante da minha explicação para o atraso e do pedido para ser readmitida, ele foi capaz de reconstruir o vínculo e continuou participando das atividades normalmente.

Cada adolescente e criança participante da Oficina possuíam uma situação judicial particular e a ansiedade gerada pela falta de uma perspectiva concreta de resolução se constituiu como um dos aspectos mais marcantes. Os casos variavam desde Gabriela que se apresentou muito ansiosa e com traços deprimidos por ter sido proibida de ver a família; Maiara que possuía uma família muito interessada, mas que ainda não apresentava condições de desacolhê-la; e Josi, cuja chegada de sua maioridade civil, Ihe fazia se sentir pressionada por todas as responsabilidades com as quais passaria a arcar. Cada uma destas meninas vivia um momento do acolhimento e tinham perspectivas diversas para futuro. Ainda neste contexto, havia Roberto que via a sua função com um preparador para a saída do abrigo, que nunca se sabia exatamente quando iria ocorrer com cada criança e adolescente. 
Por outro lado, a instabilidade da instituição adentrou o espaço da Oficina a partir do momento em que nos propusemos a construir um campo inclusivo, no qual a participação era livre e irrestrita. A rotina da casa ocasionou um fluxo de participações de abrigados e funcionários que exigiu uma adaptação frequente por parte de todos. Além de ter se feito necessária a reafirmação constante de regras de respeito mútuo para impedir a repetição de intrusões e da vivência de violência e rejeição. Dada esta característica inerente das casas abrigo, um trabalho inclusivo promove contatos humanos riquíssimos como presenciado com as participações de Guolherme, Daniela e Paula, que transitaram pela Oficina, mas deixaram marcas profundas.

Neste ponto, uma limitação deste trabalho foi exatamente não poder potencializar esta inclusão ao não absorver a demanda das educadoras que quiseram participar, mas, que por razões da divisão de tarefas na casa, não puderam. Como as relações e os vínculos afetivos mostraram-se tão construtivos para os participantes deste trabalho, quanto mais pessoas pudessem ter circulado pelas atividades, mais a Oficina teria sido efetiva em proporcionar encontros potenciais. Neste aspecto, 0 enquadre diferenciado grupal constitui-se como uma ferramenta valiosa para a realização de um trabalho terapêutico capaz de lidar com as diferenças subjetivas de modo a construir um sentido, simultaneamente, grupal e individual. Além disto, mostrou-se um instrumento de trabalho muito apropriado na oferta de um espaço terapêutico inserido numa instituição, onde as demandas são muitas e transitam entre as necessidades pessoais e institucionais.

Essa interface entre o coletivo e privado constituiu-se como um dos aspectos mais delicados deste tipo de instituição e refletiu-se na dinâmica da Oficina. Vindos de uma herança de organizações massificadoras e totalitárias (SOUZA NETO, 2001; MARCÍLIO, 1997; RIZZINI, 1993; BAPTISTA, 2006), as casas de acolhimento atualmente são uma estrutura relativamente recente, uma vez que se instituíram com a promulgação do Estatuto da Criança e do Adolescente na década de 1990 (BRASIL, 1990/2005). Ao mesmo tempo em que observamos um esforço da equipe técnica da instituição em proporcionar uma atenção individual para as necessidades de cada abrigado como prevê o art. 94 do ECA (BRASIL, 1990/2005:36), o espaço institucional e a dinâmica cotidiana são muito coletivos e notamos a dificuldade como abordou Glens (2010) de se lidar com a grande heterogeneidade impostas 
pelas diferenças entre as crianças e adolescentes. A divisão da casa em alas femininas e masculinas e a tentativa de concentração de crianças mais velhas e adolescentes (procurando-se encaminhar para outra instituição as crianças pequenas) ilustram o quanto, na prática a inclusão e a concretização do abrigo como um espaço de diversidade é complicado. Isso exige uma atenção constante da equipe para que consiga se efetivar 0 atendimento personalizado preconizado pelo Estatuto (BRASIL, 1990/2005:36, art. 92). Encara-se que, numa instituição de acolhimento, o tratamento coletivo irrestrito e impessoal pode levar a uma massificação e desrespeito do indivíduo.

Os conflitos inerentes à vivência grupal num abrigo evidenciaram-se mais abertamente nos dois últimos encontros nas quais foram propostos desenhos coletivos por sugestão da banca do exame de qualificação. $O$ desconforto gerado pela expressão através de um desenho elaborado num espaço comum - cartolina tornaram explícitas as dificuldades de se manter a individualidade em meio a coletividade e, ao mesmo tempo, de se construir uma identidade grupal. Para isso, os adolescentes recorreram a artifícios que garantisse uma expressão pessoal fisicamente delimitada, ainda que todos tenham feito desenhos dentro um campo semântico semelhante (como o ocorrido na décima primeira oficina). Essa dificuldade de compartilhamento e identificação com o outro é expressa a todo o momento através de diversos conflitos ao longo das atividades diárias que ficam expressos no último encontro quando fazem piadas e comentários preconceituosos de forma generalizada. A resistência ao compartilhamento reflete uma atitude legítima em se preservar aspectos mais pessoais para impedir uma despersonalização e desenraizamento generalizados despertados pela transitoriedade do abrigo (PARREIRA e JUSTO, 2005). Por outro lado, a renitência em se ver no outro, também é encarada como uma auto preservação na medida em que se identificar demais pode levar a se apegar demais, e numa instituição transitória, isso pode gerar mais sofrimento ao se perder outra figura de referência.

Apesar destas dificuldades, quando comparamos os desenhos coletivos do penúltimo encontro e do último, vemos um movimento diferente. No último, já não foi mais necessário delimitar fisicamente os quadrantes onde cada um desenharia. Isso nos leva a pensar nas possibilidades que a Oficina poderia ter tido caso se 
trabalhasse desta forma desde o início. É uma proposta que merecia ser aplicada em outra pesquisa.

Em consonância, no último encontro foi realizada uma pequena vernissage, na qual todos os trabalhos realizados por todos os participantes tiveram um espaço de rememoração e integração. Essa iniciativa teve, ainda, outra finalidade: dar um significado ao desligamento e à despedida. Apesar de uma resistência inicial, houve um estreitamento de laços afetivos e certos cuidados deste tipo precisam ser contemplados, principalmente no caso de uma instituição como uma casa abrigo onde os rompimentos são muito frequentes.

A memória nos permite acessar símbolos que introjetamos em algum momento e ela os retém, evitando perdas devastadoras. Ao comunicar que guardaria com carinho os desenhos que eles, por ventura, não quisessem ficar, abriu um caminho para que se vissem mantidos por mim, na minha memória de forma concreta. Tanto que a maioria dos desenhos foram deixadas comigo. A experiência do esquecimento é muito real para estas crianças e adolescentes que não possuem, muitas vezes, um contato sistemático com familiares. A fantasia de terem sido esquecidos pelos pais desperta uma angústia terrível assim como a perspectiva de não serem mais lembrados pela equipe do abrigo após o desacolhimento.

A preocupação com estes pontos que sustentam o enquadre conferiram à Oficina um lugar que procurou não repetir e institucionalizar a violência e o abandono, vivências muito presentes e doloridas tanto para os abrigados como para os funcionários. De acordo com SOUZA NETO (2001: 94) o abrigo se caracteriza, entre outros pontos, pela garantia do direito do atendimento personalizado, pelo respeito à identidade dos usuários, condições de salubridade e segurança adequados. No entanto a falta de um espaço onde as inúmeras experiências que ocorrem dentro do abrigo possam ter voz (DOTTORI et al., 2008) podem imprimir as noções de insensibilidade, desesperança e agressividade. Desta forma, propaga-se os malefícios contra os quais estas crianças e adolescentes deveriam ser protegidos (BARROS e FIAMENGHI JR., 2007). Estes pontos são completamente incompatíveis com a noção última do abrigo, como um local que deveria garantir a continuidade do desenvolvimento o mais saudável possível de crianças e adolescentes. Ocasiões infelizes como aquela relatada pela coordenadora da 
instituição em que uma educadora se vale do abandono vivido por um adolescente para manter a sua autoridade explicitam o quanto estas relações devem ser cuidadas com atenção para que o abrigo consiga cumprir sua função social e constitutiva.

É neste contexto em que trabalhos realizados a partir de enquadres diferenciados como o apresentado nesta dissertação possuem um vasto campo de atuação. Vale lembrar que, de acordo com o Código de Ética Profissional ${ }^{33}$ é um dever dos psicólogos basear o seu trabalho no respeito e dignidade assim como combater a negligência e violência. Considerando estes pilares, enquadres diferenciados pautados na teoria winnicottiana tornam-se importantes aliados na estruturação de um espaço de contato humano e elaboração criativa que culminam em experiências mutativas do self e da instituição.

Assim como o gesto de brincar, a oficina objetivou proporcionar algo que transcendeu uma apreensão estética das produções gráficas assim como a decifração de seu conteúdo (WINNICOTT, 1971/1975; AIELLO-VAISBERG; MACHADO, 2003). O intuito do relato das experiências vividas não se relaciona com a interpretação entendida pelo viés psicanalítico clássico. Eles procuraram trazer uma compreensão maior acerca das vivências testemunhadas num ambiente especializado, através de seu enquadre (WINNICOTT, 1971/1975)

\footnotetext{
${ }^{33}$ Disponível em: http://site.cfp.org.br/wp-content/uploads/2012/07/resolucao1987_2.pdf
} 


\section{CONSIDERAÇÕES FINAIS}

Consideram-se contemplados os objetivos desta pesquisa que se pautou: na compreensão das vivências emocionais de crianças e adolescentes abrigados, bem como pela experiência do acolhimento vivida pelos participantes na Oficina terapêutica que proporcionou um espaço de acolhimento, comunicação e elaboração de aspectos mal integrados relativos a esta realidade.

O estudo clínico se pautou no exame e na síntese dos dados obtidos no diagnóstico compreensivo inicial, composto pela entrevista (com o cuidador e as participantes) e a aplicação dos instrumentos (só nos jovens); no processo desencadeado pelo desenho e pela pintura ao longo dos doze encontros e pelas entrevistas devolutivas e reaplicação dos instrumentos. Constatamos que a institucionalização e o afastamento da família imprimiram marcas específicas em cada uma das meninas participantes.

O abrigo foi entendido como uma medida protetora que visou à garantia dos direitos das crianças e adolescentes (BRASIL, 1990/2005; IPEA,2003) que participaram deste estudo. Ainda que tenha sido observada, pela pesquisadora, uma preocupação e cuidado deste abrigo no trato das crianças e adolescentes, o afastamento da família e aspectos inerentes da institucionalização acarretou em sofrimento psíquico para os participantes.

Destacamos o vínculo ambivalente que se estabelece entre os abrigados e suas figuras parentais, que, de alguma forma falharam no cuidado, mas ainda constituíam-se como referências afetivas importantes, como colocado por Bowlby (1976/2001;1997) e Winnicott (1987/1999). Essa situação de abandono e afastamento das figuras parentais desencadeia vivências emocionais permeadas pela angústia e que necessitam de holding. Além disto, o caráter provisório do abrigo apregoado pelo ECA (BRASIL, 1990/2005) não se aplica sempre na prática, tendo sido observado longos períodos de institucionalização, como no caso de Josi, Maiara e Daniela. Entre seus efeitos, destacamos o forte laço afetivo que se forma entre os pares de crianças e a adolescentes abrigados e deles com seus cuidadores. 
Um aspectos muito relevante e que merece destaque são dificuldades diante da perspectiva do desacolhimento também previamente apontadas por outros pesquisadores (MARTINEZ;2006; SILVA;LEONCIO;TARDIVO, 2007; RENTES; TARDIVO, 2012), em especial com Josi. Essas questões se delinearam desde os primeiros contatos, apontando para a sensibilidade dos instrumentos utilizados no processo diagnóstico.

Observamos o quanto é importante o estabelecimento de vínculos afetivos para a continuidade do desenvolvimento como já colocara WINNICOTT, 1987/1999. O sentimento fraterno de Josi e Maiara, assim como o bom relacionamento que possuíam com Roberto se mostraram estruturantes para todos. Roberto, na posição de cuidador, vivia algumas limitações na expressão do afeto, mas, ainda assim, se constituiu numa referência importante. Assim como expressa Rotondaro (2005) e Careta (2011) vimos o desenvolvimento de vínculos saudáveis no contexto institucional. Inclusive, o estreitamento de laços mostrou-se no cerne da fantasia de cura (ABERASTURY, 1979/1986) ao se configurarem como um aspecto reparador diante da vitimização, negligência e abandono vividos no contexto familiar e que culminaram no acolhimento institucional.

A Oficina Expressiva de Desenho e Pintura pautada no conceito de enquadre diferenciado de inspiração winnicottiana (AIELLO-VAISBERG; MACHADO, 2003) mostrou-se uma modalidade interventiva efetiva para esta população como vem se configurando em outros contextos (TARDIVO e Gil, 2008). Através do uso da materialidade mediadora foi possível estabelecer um Espaço Potencial baseado na transicionalidade e no holding (WINNICOTT, 1971/1975; 1990;1991; 1988/2006) a partir do qual gestos criativos puderam ocorrer. Sendo assim, consideramos que 0 enquadre favoreceu a integração e elaboração de aspectos dissociados ligados à vivência da institucionalização o que se evidenciou na reaplicação dos instrumentos e na entrevista devolutiva. $\mathrm{O}$ aumento dos sintomas depressivos constatados neste último contato vai ao encontro deste movimento integrativo do Self.

O enquadre diferenciado breve e grupal facilitou a aderência e mostrou-se adequado ao contexto institucional. Seu aspecto inclusivo foi fundamental, principalmente, considerando-se a natureza da instituição baseada num fluxo constante de crianças e adolescentes cuja receptividade e adaptação são difíceis. 
Nesse caso, outras crianças, adolescentes e inclusive funcionários do abrigo puderam vivenciar encontros humanos na Oficina, trazendo contribuições ao processo terapêutico.

O presente estudo foi realizado com o objetivo de se efetuar um estudo clínico de crianças e adolescentes abrigados e apresentar a Oficina de Desenho e Pintura como opção de intervenção terapêutica. Desta forma, buscamos oferecer contribuições à Clínica Psicológica aplicada a esta população que vivencia sofrimento psíquico muito específico.

Portanto, reforçamos a importância da adaptação desse método psicoterapêutico aos equipamentos de saúde pública destinados à população de crianças e adolescentes abrigados que compõe uma parcela expressiva da infância e adolescência no nosso país, assim como alertamos para a necessidade de mais estudos sobre aspectos muito relevantes, como o desacolhimento e propostas que possam ser desenvolvidas visando apoiar os cuidadores e dar mais recursos aos adolescentes nesse processo.

Para finalizar, ressaltamos a necessidade de maiores estudos em relação ao contexto do acolhimento institucional de forma ampla para nos aproximarmos ainda mais dos ideais propostos pelo ECA (BRASIL, 1990/2005). Assim como no uso de enquadres diferenciados aplicados aos mais variados agrupamentos humanos para conseguirmos cumprir, ainda melhor, a função de psicólogos clínicos ancorada, no respeito e na intervenção destinada aos indivíduos em sofrimento psíquico (TARDIVO, 2008). 


\section{REFERÊNCIAS ${ }^{34}$}

AASPTJ-SP; NCA-PUC-SP; SAS; FUNDAÇÃO ORSA. Por uma política de abrigos em defesa de direitos das crianças e dos adolescentes na cidade de São Paulo: Motivos de demanda e qualidade de oferta de serviços de atenção à atenção à criança e adolescente sob medida de 'abrigo'. proteção Disponível em:http://www.mp.sp.gov.br/portal/page/portal/cao infancia juventude/rede/rede abrigos/ab rigossp.pdf. Aceso em 12/09/2011.

ABREU, S.R. Transtornos Psiquiátricos em Crianças e Adolescentes criados em Instituições. Dissertação (Mestrado). UNIFESP: São Paulo. 2000.

ABERASTURY, A. Psicanálise da criança. Porto Alegre: Artes Médicas.1986 (Trabalho original publicado em 1979).

AGOSTA, C.B.; COLOMBO, R.I.; BARILARI, Z. Abuso y maltrato infantil - Indicadores e, "Persona bajo la lluvia". Buenos Aires: Cauquén. 2006.(Trabalho original publicado em 2001.

AIELLO-VAISBERG, T. M. J. Investigação de Representações Sociais. In: W. Trinca (org.) Formas de Investigação Clínica em Psicologia. São Paulo, Vetor, 1997.

AIELLO-VAISBERG, T. M. J. Encontro com a loucura: transicionalidade e ensino de psicopatologia. Tese (Livre Docência), Instituto de Psicologia, Universidade de São Paulo, São Paulo.1999.

AIELLO-VAISBERG, T.M.J.; MACHADO, M.C.L. Sofrimento Humano e Estudo da "Eficácia Terapêutica" de Enquadres Clínicos Diferenciados. In AIELLO-VAISBERG, T.M.J.; AMBRÓSIO, F.F. Cadernos Ser e Fazer: Apresentação e Materialidade. Instituto de Psicologia. Universidade de São Paulo, 2003.

AIELLO-VAISBERG, T.M.J. Ser e Fazer: enquadres clínicos diferenciados na clínica Winnicottiana. Aparecida, SP: Ideias e Letras, 2004.

AIELLO-VAISBERG, T.M.J. Os enquadres clínicos diferenciados e a personalização/realização transicional. In: AIELLO-VAISBERG, T.M.J.; AMBRÓSIO, F.F. (orgs.) Cadernos Ser e Fazer: O brincar. São Paulo: Instituto de Psicologia da Universidade de São Paulo, 2004a. p. 06-17.

AIELLO-VAISBERG, T.M.J.; A ética na pesquisa em debate no Brasil: reflexões sobre a pesquisa psicanalítica na universidade. In. AIELLO-VAISBERG, T.M.J.; AMBROSIO, F.F. (orgs) Cadernos Ser e Fazer. Imaginários coletivos como mundos transicionais. Instituto de Psicologia. Universidade de São Paulo, 2006.

AIELLO-VAISBERG, T.M.J.; AMBROSIO, F.F. O mundo transicional papeleiro da oficina arte de papel: um enquadre diferenciado na artepsicoterpia. In V Jornada APOIAR: Saúde Mental nos ciclos da vida. São Paulo, 2007. Instituto de Psicologia, Universidade de São Paulo. 2007.

ALEXANDRE, D.T; VIEIRA, M.L. Relações de apego entre crianças institucionalizadas que vivem em situação de abrigo. Psicologia em Estudo v.9, n.2. Maringá, mai/ago,2004.

\footnotetext{
${ }^{34}$ De acordo com: Associação Brasileira de Normas Técnicas. NBR 6023.
} 
AMBROSIO, F.F. Ser e Fazer arte de papel: uma oficina inclusiva. 200. 179p.Dissertação (Mestrado em Psicologia) Instituto de Psicologia da Universidade de São Paulo. São Paulo. 2005.

AMBROSIO, F.F.; FIALHO, A.A.; AIELLO-VAISBERG, T.M.J. O imaginário coletivo de estudantes de educação física sobre vida saudável. In. VIII Jornada APOIAR: Promoção de vida e vulnerabilidade social na América Latina: Reflexões e Propostas. 2010. Anais... Instituto de Psicologia da Universidade de São Paulo. 2010. p. 281-291.

AMBROSIO. F.F. O estilo clínico 'Ser e Fazer' na investigação de benefícios clínicos de psicoterapias. 2013. 108 p. Tese (Doutorado em Psicologia) - Pontifícia Universidade Católica de Campinas, Campinas, 2013.

ANZIEU, D. Métodos Projetivos. Rio de Janeiro: Campos. 1979.

ARPINI, D.M. Repensando a perspectiva institucional e a intervenção em abrigos para crianças e adolescentes. Psicologia Ciência e Profissão. v.23, n.1, 2003. p.70-75.

BAPTISTA, M.V. Abrigo: comunidade de acolhida e socioeducação. São Paulo: Instituto Camargo Correia, 2006. 102p.

BARBOSA, G.A.; GOUVEIA, R.V.; ALMEIDA, H.J.F.; GAIÃO, A.A. Inventário de Depressão Infantil - CDI: Estudo de Adaptação com Escolares de João Pessoa. Jornal Brasileiro de Psiquiatria . 44 (7): 345-9. 1995.

BARBOSA, G.A.; LUCENA, A. Depressão Infantil. Infanto - Revista de Neuropsiquiatria da infância e adolescência. v.3, n.2. p. 23-30. 1995.

BARCELOS, T.F.; CIA, W.C.; AIELLO-VAISBERG, T.M.J. Caminhos possíveis: o imaginário coletivo de professores sobre o adolescente contemporâneo. In. IX Jornada APOIAR: Violência Doméstica e trabalho em rede compartilhando experiências: Brasil, Argentina, Chile e Portugal. 2011. Anais... Instituto de Psicologia da Universidade de São Paulo. São Paulo, 2011. p. 187-198.

BARROS, G.D.; CASSIN, W.C.; DUARTE, S.H.S.A.; FELIPE, S.S.R.; FRANCO, M.L.F.; GALLO, C.M.L.; PERUCHI, M.I.; SERRANO, S.A. A teoria do apego e a formação e rompimento de vínculos: perspectivas teóricas sobre os efeitos do abrigamento em crianças e adolescentes. In. FRANCO, A.A.P.; MELÃO, M.J.R. (orgs.) Diálogos Interdisciplinares: a Psicologia e o Serviço Social nas práticas judiciárias. São Paulo: Casa do Psicólogo, 2007.

BARROS, R.C.; FIAMENGHI Jr, G.A. Interações afetivas de crianças abrigadas: um estudo etnográfico. Ciência e Saúde Coletiva. 1267-1276.v. 12, n. 5. p. 1267-1276. 2007. Disponível em: http://www.scielo.br/pdf/csc/v12n5/18.pdf. Acessado em 06/03/2011.

BARROS, M.S.M.; GIL, C.A.; TARDIVO, L.S.P.C. Encontro criativo: relato de um caso clínico. In. VI Jornada Apoiar: Saúde Mental e Violência - Contribuições no Campo da Psicologia Clínica Social. 2008. Anais... Instituto de Psicologia da Universidade de São Paulo. 2008. São Paulo. p. 505-510.

BERGER, M.V.B. \& GRACINO, E.R. Aspectos históricos e educacionais dos abrigos de crianças e adolescentes: a formação do educador e o acompanhamento dos abrigados. Revista HISTEDBR Online, Campinas, ํo18, p. 170-185. Jun. 2005. Disponível em: $<$ http://www.histedbr.fae. unicamp.br/revista/revis/revis18/art17 18.pdf.> Acesso em: 23/11/2011. 
BLEGER, J. A entrevista psicológica - seu emprego no diagnóstico e na intervenção. In. Temas de Psicologia - Entrevista e Grupos. Buenos Aires: Martins Fontes. 1964.

BLEGER, J. Psico-Higiene e Psicologia Institucional. São Paulo: Artmed, 1984. 138p.

BLEGER, J. Psicologia da conduta. Porto Alegre: Artes Médicas, 1984. (Trabalho Original publicado em 1963).

BLEGER, J. Psicanálise do enquadramento psicanalítico. In: BLEGER, J. Simbiose e Ambiguidade. Rio de Janeiro: Francisco Alves, 1988. p. 311-328.

BOWLBY, J. Apego e perda. São Paulo: Martins Fontes. 1985.

BOWLBY, J. Formação e Rompimento dos Laços Afetivos. 3ª edição. São Paulo: Martins Fontes, 1997. 228p.

BOWLBY, J. Cuidados Maternos e Saúde Mental. 4aa edição. São Paulo: Martins Fontes, 2001. (Trabalho original publicado em 1976). 239p.

BRASIL. Estatuto da Criança e do Adolescente. Lei no. 8.069, de 13 de julho de 1990. Brasília: Senado Federal. 2005.177p. Disponível em: <http://www.planalto.gov.br/ ccivil 03/leis/L8069.htm>. Acesso: 04/01/2013.

CAMPS, C.I.C.M. A hora do beijo - teatro espontâneo com adolescentes numa perspectiva winnicottiana.Dissertação (Mestrado em Psicologia). Instituto de Psicologia da Universidade de São Paulo. São Paulo. 2003.

CAMPS, C.I.C. de M. C. Ser e Fazer na escolha profissional: atendimento diferenciado na clínica winnicottiana. 213p. Tese (Doutorado em Psicologia) - Instituto de Psicologia, Universidade de São Paulo. São Paulo, 2009.

CARETA, D.S. Análise do desenvolvimento emocional de gêmeos abrigados no primeiro ano de vida. 2006. 249p. Dissertação (Mestrado em Psicologia) - Instituto de Psicologia, Universidade de São Paulo,São Paulo, 2006.

CARETA, D.S.; MOTTA, I.F. O desenho livre como fenômeno transicional no atendimento grupal de monitoras de um abrigo. São Paulo. 2007. In. Jornada do Espaço Potencial Winnicott: diversidade e interlocução. São Paulo: Instituto Sedes Sapientiae. 2007 p. 19

CARETA, D.S.; MOTTA, I. F. A história dos gêmeos Daniel e Mathias abrigados no primeiro ano de vida: retratos de violência e desamparo e necessidade de intervenções em contexto institucionais. São Paulo. 2008. In. VI Jornada Apoiar: Saúde Mental e Violência: contribuições no campo da psicologia clínica social. São Paulo, Anais... São Paulo, 2008a.

CARETA, D.S.; MOTTA, I.F. Reflexões éticas sobre o tratamento e o desenvolvimento de uma criança abrigada: a importância do encontro inter-humano. 2008. In. VI Jornada APOIAR: Saúde Mental e Violência - contribuições no campo da psicologia clínica social. 2008. Anais... São Paulo: Instituto de Psicologia da Universidade de São Paulo. 2008c. p.286-299.

CARETA, D.S.; MOTTA, I.F. Intervenção psicoterápica com cuidadoras de um abrigo: alcances e limites na promoção de saúde. In. Anais do Encontro do Programa de Pós 
Graduação em Psicologia Clínica. São Paulo. 2009. São Paulo: Instituto de Psicologia. Universidade de São Paulo. 2009.

CARETA, D.S.; MOTTA I.F. Núcleo de Abrigos - LAPECRI USP da Universidade para a comunidade. In. VII Jornada APOIAR: Saúde Mental e Enquadres Grupais - a pesquisa e a clínica. São Paulo. 2009. Anais... São Paulo: Instituto de Psicologia da Universidade de São Paulo. 2009a. p.137-149.

CARETA, D. S. Quando o ambiente é o abrigo: cuidando das cuidadoras de crianças em acolhimento institucional. 2011. Tese (Doutorado em Psicologia Clínica) - Instituto de Psicologia, Universidade de São Paulo, São Paulo, 2011. Disponível em: <http://www.teses.usp.br/teses/disponiveis/47/47133/tde-14062011-161730/>. Acesso em: 26/05/2010.

CASTRO, R.P.; COLACIQUE, M.A.M, TARDIVO, L.S.P.C. A importância do holding na vivência de uma adolescente abrigada e o vínculo terapêutico. In. X Jornada APOIAR: o laboratório de saúde mental e psicologia clínica social -20 anos: o percurso e o futuro. 2012. São Paulo. Anais... São Paulo: Instituto de Psicologia da Universidade de São Paulo. 2012. p. 446-458.

CIA, W.C.; AMBROSIO, F.F.; AIELLO-VAISBERG, T.M.J. Um trabalho clínico social: a oficina de histórias, fotos e lembranças da Ser e Fazer. In. V Jornada APOIAR: Saúde Mental nos ciclos da vida. 2007. São Paulo. Anais... Instituto de Psicologia, Universidade de São Paulo. São Paulo, 2007.

CORBETT, E. GALLO-BELLUZZO, AIELLO-VAISBERG, T.M.J. Imaginário coletivo de estudantes de psicologia sobre dificuldades sexuais femininas no contexto da "sexualidade invasiva". In. VIII Jornada APOIAR: Promoção de vida e vulnerabilidade social na América Latina: Reflexões e Propostas. 2010. Anais... Instituto de Psicologia da Universidade de São Paulo. 2010. p. 297-302.

DELL'AGLIO, D.D. O processo de coping, institucionalização e eventos de vida em crianças e adolescentes. 2000, 119p.Tese (Doutorado em Psicologia) - Universidade Federal do Rio Grande do Sul. Porto Alegre, 2000.

DELL'AGLIO, D.D.; HUTZ, C.S. Depressão e desempenho escolar em crianças e adolescentes institucionalizados. Psicologia: Reflexão e Crítica v. 17, n. 3, p. 341-350, 2004 http://www.scielo.br/pdf/prc/v17n3/a08v17n3.pdf Acessado em 06/03/2011

DOTTORI, P.; BERTTRAN, D.; MEICHETTI, D.; LEONCIO, W.A.H.; TARDIVO, L.S.P.C. Abrigo de adolescentes: 0 ambiente afetivo através dos relatos de funcionários e educadores. In. VI Jornada APOIAR: Saúde Mental e Violência: Contribuições no campo da psicologia clínica social. 2008. São Paulo. Anais... São Paulo: Instituto de Psicologia, Universidade de São Paulo, 2008. p. 261-269.

DÜSS, L. Fábulas de Düss: o método das fábulas em psicanálise infantil. São Paulo: Casa do Psicólogo, 1986.

FROMER, L. O abrigo: uma interface no atendimento à criança e ao adolescente vítimas de violência intrafamiliar. In: FERRARI, D. C. A.; VECINA, C.C.A. (Orgs.) O fim do silêncio na violência familiar. Teoria e Prática. São Paulo: Ágora, 2002. p. 311-315. 
GALHEIGO, S.M. O abrigo para crianças e adolescentes: considerações acerca do papel do terapeuta ocupacional. Revista de Terapia Ocupacional da Universidade de São Paulo. v.14, n.2. p.85-94. Mai/ago, 2003.

GALLO-BELUZZO, S.R.; CORBETT, E.; AIELLO-VAISBERG, T.M.J Imaginário coletivo de estudantes de psicologia sobre o primeiro atendimento clínico. In. VIII Jornada APOIAR: Promoção de vida e vulnerabilidade social na América Latina: Reflexões e Propostas. 2010. Anais... Instituto de Psicologia da Universidade de São Paulo. 2010. p. 273-280.

GIL, C.A. Recordação e transicionalidade: a oficina de cartas fotografias e lembranças como intervenção psicoterapêutica grupal com idoso. 2010. 174p. Tese (Doutorado em Psicologia) - Instituto de Psicologia, Universidade de São Paulo. São Paulo, 2010.

GLENS, M.. Órfãos de pais vivos: uma análise da política pública de abrigamento no Brasil. 2010. Dissertação (Mestrado em Psicologia Escolar e do Desenvolvimento Humano) Instituto de Psicologia, Universidade de São Paulo, São Paulo, 2010. Disponível em: $<$ http://www.teses.usp.br/teses/disponiveis/47/47131/tde-09112010-113124/>. Acesso em: 05/06/2010.

GOODENOUGH. F.L Test de inteligência infantil por médio de La figura humana. Buenos Aires: Paidos.1951. (Trabalho original publicado em 1926).

GRASSANO, E. Indicadores psicopatológicos nas técnicas projetivas. São Paulo: Casa do Psicólogo. 1996.

GULASSA, M.L.C.R. A fala dos abrigos. In. Abrigo: comunidade de acolhida e sócio educação. São Paulo: Instituto Camargo Correia, 2006. p. 53- 61.

HAMMER, E.F. Aplicações Clínicas dos Desenhos Projetivos. Rio de Janeiro:Interamericana.1981.

HARRIS, D.B. El test de Goodenough: Revisión, ampliación y actualización. Buenos Aires: Paidós. 1963.

HERRMANN, F. Pesquisando com o método psicanalítico. In HERRMANN, F. Pesquisando com o método psicanalítico. São Paulo: Casa do Psicólogo, 2004.p. 43-83.

IPEA. O direito à convivência familiar e comunitária: os abrigos para crianças e adolescentes no Brasil. IPEA, 2003. Disponível em <http://www.mp.sp.gov.br/ portal/page/portal/infanciahome_c/acolhimento_institucional/Doutrina_abrigos/IPEA._Levant amento_Nacional_de_abrigos_para_Criancas_e_Adolescentes_da_Rede_SAC.pdf Acesso: 12/09/2011.

KAËS, R. Realidade psíquica e sofrimento nas instituições. In. KAËS, et al., A instituição e as instituições. São Paulo: Casa do Psicólogo, 1991. 184p.

KAËS, R. A instituição como herança, mitos de fundação, transmissões, transformações. Aparecida: Ideias \& Letras, 2011. 223p.

KOPPITZ, E.M. El Dibujo de la figura humana em los niños. Buenos Aires:Guadalupe. 1973. (Trabalho original publicado em 1968). 
KOVACS, M.A. Developmental Perspective on Methods and Measures in the Assessment of Depressive Disorders: The Clinical Interview. In RUTTER, M.; IZARD, C.; READ, P.; (eds.). Depression in Young People: Developmental and Clinical Perspectives. Guilford Press: Nova York. 1983.

LABATE, C.G; COSTA, I.M.A.; TURNA, J.W.T. TARDIVO, L.S.P.C. Oficina Psicoterapeutica: contos de fadas com pacientes psiquiátricos. In. TARDIVO, L.S.P.C.; GIL, C.A. APOIAR novas propostas em psicologia clínica. Sarvier: São Paulo. 2008.

LEONCIO, W. A. H. Retrato de vivências emocionais de crianças recém-abrigadas: observações psicanalíticas por meio do Procedimento de Desenho-Estória. 2003. Dissertação (Mestrado em Psicologia Clínica). Instituto de Psicologia, Universidade de São Paulo. São Paulo, 2003.

LEONCIO, W.A.H. \& TARDIVO, L.S.P.C. Consultas terapêuticas de uma criança abrigada e sua mãe: maternando mãe e filha. In. V Jornada APOIAR: Saúde Mental nos ciclos da vida. 2007. São Paulo. Anais... São Paulo: Universidade de São Paulo, Instituto de Psicologia, 2007, p.208-232.

LEONCIO, W.A.H. Consultas terapêuticas de crianças abrigadas e seus pais: uma intervenção dos vínculos familiares. 2009. Tese (Doutorado em Psicologia). Instituto de Psicologia da Universidade de São Paulo. 2009.

LOURENÇÃO van KOLCK, O. Testes Projetivos Gráficos no Diagnóstico Psicológico, São Paulo: EPU 1984.

LOURENÇÃO van KOLCK, O. Interpretação Psicológica de Desenhos. São Paulo: Pioneira, 1981.

LUDKE, M.; ANDRÉ, M. Pesquisa em educação: abordagens qualitativas. São Paulo: EPU, 2006.

LUZ, V.M.M.; SOUZA, G.S. ASSIS, L.L.; GIL, C.A.; VAGOSTELLO, L. A percepção de crianças institucionalizadas sobre o abrigamento por meio do desenho-estória com tema. In. IX Jornada APOIAR: Violência doméstica e trabalho em rede compartilhando experiências: Brasil, Argentina, Chile e Portugal. 2011. São Paulo. Anais... São Paulo: Instituto de Psicologia da Universidade de São Paulo. 2011. p. 446.

MACHOVER, K.A. Proyéction de La personalidad em El dibujo de La figura humana: um método de investigación de La personalidad. La Habana: Cultural.1949.

MANNA, R.E.; AIELLO-VAISBERG, T.M.J. Oficinas psicoterapêuticas de tapeçaria e outros bordados: bordando a vida ponto-a-ponto. In. AIELLO-VAISBERG, T.M.J.; AMBROSIO, F.F. (orgs) Cadernos Ser e Fazer. Imaginários Coletivos como Mundos Transicionais. Instituto de Psicologia. Universidade de São Paulo. São Paulo, 2006.

MANNA, R.E.; CRUZ, M.S.; AIELLO-VAISBERG, T.M.J., TARDIVO, L.S.P.C. Estilo clínico Ser e Fazer e entrevistas terapêuticas para abordagem de pessoalidades coletivas. In. $X$ Jornada APOIAR: o laboratório de saúde mental e psicologia clínica social - 20 anos: o percurso e o futuro. 2012. Anais... Instituto de Psicologia da Universidade de São Paulo. São Paulo, 2012. p. 315-323

MARCÍLIO, M.L. História social da criança abandonada. São Paulo: Hucitec. 331p.1999. 
MARTINEZ, A.L.M. Adolescentes no momento de saída do abrigo: um olhar para os sentidos construídos. 2006. 240p. Dissertação (Mestrado em Psicologia) - Faculdade de Filosofia, Ciências e Letras de Ribeirão Preto/USP. Ribeirão Preto. 2006.

MENCARELLI, V.L.; BASTIDAS, L.S.; AIELLO-VAISBERG, T.M.J. Violência sexual: um acompanhamento realizado na oficina de velas ornamentais. In AIELLO-VAISBERG, T.M.J.; AMBROSIO, F.F. Cadernos Ser e Fazer. Apresentação e Materialidade. Instituto de Psicologia, Universidade de São Paulo. São Paulo, 2003.

MENCARELLI, V.L. Em defesa de uma clínica psicanalítica não convencional: oficina de velas ornamentais com pacientes soropositivos. Dissertação (Mestrado em Psicologia). Instituto de Psicologia da Universidade de São Paulo. São Paulo. 2003.

NAKAGAWA, R.T.B., CARETA, D.S.; MOTTA, I.F. O brincar como marca da presença viva do terapeuta: contibuições ao desenvolvimento psíquico de crianças abrigadas. In. VI Jornada APOIAR: Saúde Mental e Violência: contribuições no campo da psicologia clínica social. São Paulo. 2008.Anais... São Paulo: Instituto de Psicologia da Universidade de São Paulo.

OCAMPO, M.L.S.; ARZENO, M.E.G.; PICCOLO, E.N.G. O processo psicodiagnóstico e as técnicas projetivas. São Paulo: Martins Fontes, 1981.

OLIVEIRA, R.C. A história começa a ser revelada: panorama atual do abrigamento no Brasil, 2006. In. BAPTISTA, M.V. (org.) Abrigo: comunidade de acolhida e socioeducação. São Paulo: Instituto Camargo Correia, 2006. 102p.

OLIVEIRA, A.P.G. O caráter provisório do abrigo e a passagem adolescente: pensando transitoriedades. 2006. Dissertação (Mestrado em Psicologia) - Porto Alegre: Instituto de Psicologia, Universidade Federal do Rio Grande do Sul, 2006, 225p.

PARENTE, K.S.; LEONCIO, W.A.H.; TARDIVO, L.S.P.C. A criança em situação de abrigamento: intervenção junto à mãe social. In. TARDIVO, L.S.P.C.; GIL, C.A. APOIAR novas propostas em psicologia clínica. São Paulo: Sarvier. 2008.

PARREIRA, S.M.C.P.; JUSTO, J.S. A criança abrigada: considerações acerca do sentido da filiação. Psicologia em Estudo, Maringá. v.10, n.2, p. 175-180, mai/ago. 2005.

PASCHOALETTI, I.D.; CARETA, D.S.; MOTTA, I.F. O atendimento psicológico à família de crianças abrigadas: estudo de caso. São Paulo. 2008. In. Anais da VI Jornada APOIAR: Saúde Mental e Violência: contribuições no campo da psicologia clínica social. São Paulo: Instituto de Psicologia da Universidade de São Paulo. 2008.

PASSARINI, G.M.R.; COLCACIQUE, M.A.M.; TARDIVO, L.S.P.C. Intervenção com oficinas psicoterapêuticas em mães adolescentes em instituição de acolhimento. In. X Jornada APOIAR: O laboratório de saúde mental e psicologia clínica social - 20 anos: o percurso e o futuro. 2012. São Paulo. Anais... São Paulo: Instituto de Psicologia da Universidade de São Paulo. 2012. p. 353-366.

PINEDA, D. Acolhimento institucional e modos de subjetivação. 2012. Dissertação (Mestrado em Psicologia Escolar e do Desenvolvimento Humano) - Instituto de Psicologia, Universidade de São Paulo, São Paulo, 2012. Disponível em: <http://www.teses.usp.br/teses/disponiveis/47/47131/tde-25072012-145410/>. Acesso em: 04/02/2013. 
PINTO JÚNIOR, A. \& TARDIVO, L.S.P.C. Inventário de Frases no Diagnóstico de Violência Doméstica contra crianças e adolescentes. São Paulo: VETOR. 2010.

POLITZER, G. Crítica dos fundamentos da Psicologia. Lisboa: Presença, 1975. (Trabalho original publicado em 1928).

PROCHET, N.M.S. O jogo do rabisco: um espaço compartilhado: reflexões sobre as contribuições de Winnicott ao diagnóstico psicológico. Dissertação (Mestrado em Psicologia) - Instituto de Psicologia, Universidade de São Paulo. 1993.

QUEROL, S.M. \& PAZ, M.I. Adaptación y Applicación del Test de la Persona Bajo la Lluvia. Buenos Aires: JVE/Psiqué, 1997.

RENTES, R.; TARDIVO, L.S.P.C. O olhar do lado de lá: Perspectivas, ressonâncias e consequências na vida de crianças e adolescentes abrigados. In. X Jornada APOIAR: o laboratório de saúde mental e psicologia clínica social - 20 anos: o percurso e o futuro. São Paulo. 2012. Anais... São Paulo: Instituto de Psicologia da Universidade de São Paulo. 2012. p. 423-441.

RIZZINI, I. A assistência à infância no Brasil: uma análise de sua construção. Rio de Janeiro: Editora Universitária Santa Úrsula, 1993.190p.

RIZZINI, I; RIZZINI, I. A institucionalização de crianças no Brasil: percurso histórico e desafios do presente. $2^{2}$ edição. São Paulo: Loyola, 2004.

ROTONDARO, D.P. O abrigo pode ser um ambiente facilitador do desenvolvimento de crianças e adolescentes? Grupo psicoterapêutico como instrumento de trabalho. 2005 136p. Dissertação (Mestrado em Psicologia) - Instituto de Psicologia da Universidade de São Paulo. São Paulo, 2005.

SAFRA, G. A face estética do self: teoria e critica. São Paulo: Unimarco. 1999.

SCHVARTZAID, I.G.L., SCHWARZ, L.R.; TARDIVO, L.S.P.C. Recursos expressivos na psicoterapia breve de adultos com sintomas depressivos. In. IX Jornada APOAIR: Violência doméstica e trabalho em rede compartilhando experiências; Brasil, Argentina, Chile e Portugal. 2011. Anais... Instituto de Psicologia da Universidade de São Paulo. 2011 p. 277.

SENDÍN, M.C. Diagnóstico Psicológico: bases conceptuales y guía práctica en los contextos clínico y educativo. Madri: Psimática, 2000.

SERAFINI, A.J.; ÁVILA, M.T.; BANDEIRA, D.R. Teste das Fábulas comparando respostas comuns de crianças abrigadas e respostas populares da amostra padronizada. Psico, v.36, n 3. Porto Alegre. PUCRS, p. 251-257. Set/dez, 2005.

SERRANO, S.A. O abrigamento de crianças de zero a seis anos de idade em Ribeirão Preto: caracterizando este contexto. 2008. 250p. Tese (Doutorado em Psicologia). Faculdade de Filosofia, Ciências e Letras de Ribeirão Preto, Universidade de São Paulo. Ribeirão Preto, 2008.

SNAS/MDS; FIOCRUZ. Levantamento nacional de crianças e adolescentes em serviços de acolhimento Disponível em: http://boaspraticasconvfamiliar .org.br/cms/downloads/doc download/17-levanta mento-nacional-de-criancas-e- 
adolescentes-em-servicos-de-acolhimento-institu cional-e-familiar.html. Acesso em: $12 / 09 / 2011$

SILVA, R.A.; COLACIQUE, M.A.M; TARDIVO, L.S.P.C. A dificuldade da vivência do luto por uma criança abrigada: relato de caso. In. VIII Jornada APOIAR: Promoção de vida e vulnerabilidade social na América Latina - Reflexões e Propostas. 2010 São Paulo. Anais... São Paulo: Instituto de Psicologia da Universidade de São Paulo. 2010. p. 137-143.

SILVA, E.C.P.; LEONCIO, W.H.; TARDIVO, L.S.P.C. Do abrigamento ao desabrigamento: considerações sobre a vivência de um adolescente. In. V Jornada APOIAR: Saúde Mental nos ciclos da vida. 2007. São Paulo. Anais... São Paulo: Universidade de São Paulo. Instituto de Psicologia, 2007, p. 233-247.

SIMÕES, C.H.D. RIEMENSCHNEIDER, F.; AIELLO-VAISBERG, T.M.J. "Vítimas da sociedade contemporânea": imaginário de trabalhadores de saúde mental sobre o paciente psiquiátrico. In. X Jornada APOIAR: o laboratório de saúde mental e psicologia clínica social - 20 anos: o percurso e o futuro. 2012. Instituto de Psicologia da Universidade de São Paulo. 2012. p. 254-265.

SIQUEIRA, A.C. \& DELL'AGLIO, D.D. O impacto da institucionalização na infância e na adolescência: uma revisão de literatura. Psicologia \& Sociedade, Porto Alegre, Universidade Federal do Rio Grande do Sul. v. 18 n. 1. Jan. /Abril. Porto Alegre, 2006. p. 71-80.

SILVA, D.C.; SHIROMA, M.S.X., TARDIVO, L.S.P.C, YAMAMOTO, K. Oficinas psicoterapêuticas no Hospital Psiquiátrico: uma proposta de atenção psicológica em saúde mental. In. VIII Jornada APOIAR: Promoção de vida e vulnerabilidade social na América Latina - Reflexões e Propostas. 2010. Instituto de Psicologia da Universidade de São Paulo. São Paulo, 2010. p. 237-246.

SOUZA NETO, J.C. Crianças e adolescentes abandonados - estratégias de sobrevivência. São Paulo: Expressão \& Arte, 2001. 191p.

TAFNER, A.M.S.; COLACIQUE, M.A.M.; TARDIVO, L.S.P.C. O Jogo do Rabisco como comunicação: a interação dos traços no contexto terapêutico. In. IX Jornada APOIAR: violência doméstica e trabalho em rede compartilhando experiências: Brasil, Argentina, Chile e Portugal. 2011. São Paulo. Anais... São Paulo: Universidade de São Paulo. Instituto de Psicologia, 2011, p. 239-247.

TAKUSHI, A.L.; LEONCIO, W.A.H.; TARDIVO, L.S.P.C. Acompanhamento das vivências emocionais de uma criança abrigada. In. TARDIVO, L.S.P.C.; GIL, C.A. APOIAR: Novas propostas em psicologia clínica. São Paulo: Sarvier, 2008, p. 472-482.

TARDIVO, L.S.P.C. Normas para a avaliação do procedimento de desenhos-estória numa amostra de crianças paulistanas de 5 a 8 anos de idade. 1986. 208p. Dissertação (Mestrado em Psicologia) - Instituto de Psicologia, Universidade de São Paulo. São Paulo, 1986.

TARDIVO, L.S.P.C. O teste de apercepção infantil e o teste das fábulas de Düss: respostas típicas na população brasileira e aplicação no contexto das técnicas projetivas. São Paulo: Vetor,1998.

TARDIVO, L.S.P.C., PINTO JÚNIOR, A.A. \& SANTOS, M.R. dos (2005) Avaliação psicológica de crianças vítimas de violência doméstica por meio do teste das fábulas de Düss. PSIC - Revista de Psicologia da Vetor Editora, v. 6, no 1, p. 59-66, Jan./Jun. 2005. 
TARDIVO, L.S.P.C. Adolescência e Sofrimento Emocional. São Paulo: Vetor, 2007.

TARDIVO, L.S.P.C. Psicodiagnóstico interventivo: uma proposta de ensino em Atendimento Clínico. Mudanças - Psicologia da Saúde, v.15, n 2.p. 128-134. Jul/dez 2007 a.

TARDIVO, L.S.P.C. O Projeto APOIAR e o Laboratório de Saúde Mental e Psicologia Clínica Social: Relato de uma trajetória. In TARDIVO, L.S.P.C.; GIL, C.A. (orgs) APOIAR - novas propostas em psicologia clínica. Sarvier: São Paulo. 2008.p. 3-8.

TARDIVO, L.S.P.C.; GIL, C.A. APOIAR - novas propostas em psicologia clínica. Sarvier: São Paulo. 2008.

TINOCO, V. O luto em instituições de abrigamento; um desafio para cuidadores temporários. Dissertação (Mestrado em Psicologia) - Pontifícia Universidade Católica de São Paulo, 2007. 247p.

TIRONI, C.M.R.; COLACIQUE, M.A.M.; TARDIVO, L.S.P.C. O brincar de uma criança abrigada por motivo de negligência, no contexto do processo psicoterapêutico. In. IX Jornada APOIAR: Violência doméstica e trabalho em rede compartilhando experiências: Brasil, Argentina, Chile e Portugal. São Paulo. 2011. Anais... São Paulo: Instituto de Psicologia da Universidade de São Paulo. 2011. p. 347- 357.

TRINCA, W. O desenho livre como estímulo de apercepção temática. Tese (Doutorado em Psicologia). Instituto de Psicologia, Universidade de São Paulo. São Paulo, 1972.

TRINCA, W. - Diagnóstico Psicológico: A Prática Clínica. São Paulo: EPU, 1984.

TURATO, E.R. A questão da complementaridade e das diferenças entre os métodos quantitativos e qualitativos de pesquisa: uma discussão epistemológica necessária. In. GRUBRITS, S.. NORIEGA, J.A.V. Método qualitativo: epistemologia, complementaridades e campos de aplicação. São Paulo: Vetor. 2004. p.17-51.

VAGOSTELLO, L. $\underline{O}$ emprego da Técnica do Desenho da Pessoa na Chuva: uma contribuição ao estudo psicológico de crianças vítimas de violência doméstica. 2007. 185p.Tese (Doutorado em Psicologia) - Instituto de Psicologia, Universidade de São Paulo. São Paulo, 2007.

VENANCIO, R.P. Famílias Abandonadas: assistência à criança de camadas populares no Rio de Janeiro e em Salvador: séculos XVIII e XIX. Campinas: Papirus, 1999. 190p.

VITALI, L.M.; AIELLO-VAISBERG, T.M.J. "Flor-Rabisco": oficina psicoterapêutica de arranjos florais. In AIELLO-VAISBERG, T.M.J.; AMBROSIO, F.F. Cadernos Ser e Fazer. Apresentação e Materialidade. Instituto de Psicologia. Universidade de São Paulo. 2003.

VITALI, L.M. Flor-rabisco: narrativa psicanalítica sobre uma experiência surpreendente. 189p. 2004. Dissertação (Mestrado em Psicologia). Instituto de Psicologia da Universidade de São Paulo. São Paulo. 2004

WINNICOTT, D.W. O brincar e a realidade. Rio de Janeiro: Imago, 1975. 208p. (Trabalho original publicado em 1971).

WINNICOTT, D.W. Consultas Terapêuticas em psiquiatria infantil. Rio de Janeiro: Imago, 1984. 
WINNICOTT, D.W. Gesto espontâneo. São Paulo: Martins Fontes: 1987.

WINNICOTT, D.W. Ambiente e os processos de maturação: estudo sobre a teoria do desenvolvimento emocional. 3ª edição. Porto Alegre: Artes Médicas, 1990. 268p.

WINNICOTT, D.W. Holding e interpretação. São Paulo: Martins Fontes, 1991.

WINNICOTT, D.W. Privação e Delinquência. 3aㅡ edição. São Paulo: Martins Fontes, 1999 (Trabalho original publicado em 1987). 322p.

WINNICOTT, D.W. Desenvolvimento emocional primitivo. In. WINNICOTT, D.W. Da pediatria à psicanálise. Rio de Janeiro: Imago, 2000. p. 218-232. (Trabalho original publicado em 1945).

WINNICOTT, D.W. A observação de bebês numa situação padronizada. In. WINNICOTT, D.W. Da pediatria à Psicanálise. Rio de Janeiro: Imago, 2000. p. 112-132. (Trabalho original publicado em 1941).

WINNICOTT, D.W. Os bebês e suas mães. São Paulo: Martins Fontes, 2006 (Trabalho original publicado em 1988). p. 73-78. 


\section{ANEXOS}

\section{ANEXO A}

Termo de Consentimento Livre e Esclarecido ${ }^{35}$

\section{Universidade de São Paulo \\ Instituto de Psicologia \\ Departamento de Psicologia Clínica}

\section{I - Dados sobre a Pesquisa}

Título do estudo: Oficinas expressivas de desenho e pintura com crianças e adolescentes abrigados junto com seu cuidador.

Esse é um estudo sobre psicoterapia em grupo destinada a crianças e adolescentes abrigados e sua/seu cuidador principal, a ser desenvolvido para a Dissertação de Mestrado de Aline Moreira da Silva Tafner (CRP: 06/96145; RG: 33.765.821-2; CPF: 333.777.108.41) sob a orientação da Prof ${ }^{\underline{a}}$ Livre Docente Leila Salomão de La Plata Cury Tardivo.

Para tanto, solicitamos sua colaboração na participação do presente estudo e fazemos os seguintes esclarecimentos:

1. O objetivo do estudo é compreender os efeitos e possíveis benefícios que a oficina de pintura e desenho possa trazer às crianças e adolescentes abrigados e seu cuidador. Além disso, visamos ao estudo de aspectos emocionais dos participantes. O estudo tem apenas finalidades acadêmicas e científicas.

\footnotetext{
${ }^{35}$ Obrigatório para pesquisa científica com seres humanos - Resolução № 01 de 13/06/1988 - CNS - Conselho Nacional de Saúde.
} 
2. A assinatura deste Termo, autorizando a participação das crianças e adolescentes que aceitarem participar do estudo, será solicitada ao responsável por elas no abrigo. A autorização do cuidador que aceitar participar das oficinas será consentida por ele próprio.

3. Serão realizadas entrevistas com cada criança e adolescente cujo objetivo será o de fornecer informações sobre o estudo. Caso concordem em participar das oficinas, será realizada a aplicação de instrumentos psicológicos de fácil compreensão e que exigem respostas simples. O participante poderá se recusar a fornecer qualquer resposta e solicitar esclarecimentos a qualquer momento.

4. Será realizada uma entrevista com o cuidador que participará das oficinas, cujo intuito é conhecer melhor a relação dele com as crianças e o abrigo.

5. Serão realizadas 12 oficinas de pintura e desenho, uma por semana, com 90 minutos de duração cada uma. Os encontros se darão no próprio abrigo, em grupo composto pelas crianças e adolescentes, seu cuidador e a pesquisadora. Durante as oficinas os participantes serão convidados a desenharem e/ou pintarem. Estas produções serão afixadas num mural e a seguir todos poderão falar sobre 0 que foi realizado pelos membros do grupo. Os participantes poderão permanecer no espaço da Oficina mesmo que não queiram desenvolver a atividade.

6. Após os 12 encontros, cada participante será convidado para uma entrevista individual, na qual serão reaplicados alguns dos instrumentos psicológicos usados no início. O objetivo é avaliar possíveis mudanças após a oficina. Nesta entrevista, o participante será convidado a falar sobre como foi a experiência das oficinas para ele e o espaço estará aberto para quaisquer esclarecimentos.

7. Os dados obtidos neste estudo poderão ser publicados, sendo, sempre, garantido o anonimato.

8. A participação nas oficinas de pintura e desenho não constitui nenhum risco aos seus participantes, em geral. Porém, se alguma criança demonstrar sinal de angústia será apoiada pela pesquisadora. E precisando de atendimento, será encaminhada a serviço que proceda ao tratamento.

9. Os participantes, bem como a direção do abrigo, têm o direito de pedir qualquer esclarecimento acerca da pesquisa a qualquer momento.

10. Os participantes da oficina poderão deixar de participar das mesmas a qualquer momento, sem quaisquer consequências ou prejuízos. 
11. É garantido o sigilo e a confidencialidade em toda a participação neste estudo.

12. Contato para esclarecimentos com a pesquisadora, Aline Tafner, em qualquer momento: (11) 99577971 - Endereço Av. Prof. Mello Moraes, 1721, Cidade Universitária, São Paulo.

II - Autorização

Após os esclarecimentos dos objetivos e procedimentos do presente estudo, tendo garantida a não identificação dos participantes e do abrigo, manifesto meu consentimento em participar do estudo, sendo que este Termo é preenchido em duas vias, permanecendo uma em seu poder, e outra com a pesquisadora responsável.

São Paulo, 09 de setembro de 2011

Nome do responsável (Diretor do Abrigo):

RG do responsável:

Nome do participante:

Assinatura do responsável:

Assinatura da Pesquisadora Responsável pela Pesquisa

Aline Moreira da Silva Tafner

CRP: 06/96145 


\section{ANEXO B}

\section{Principais categorias de representação da chuva e interpretações no Teste do Desenho da Pessoa na Chuva (QUEROL; PAZ, 1997).}

\begin{tabular}{|c|c|}
\hline Representação & Interpretação \\
\hline Nuvens & $\begin{array}{l}\text { "pressão, ameaça... Podem representar tendências auto- } \\
\text { agressivas ou doenças psicossomáticas (nuvens espessas)" } \\
\text { (p.75) }\end{array}$ \\
\hline Chuva & $\begin{array}{l}\text { "representa a hostilidade do meio a qual o sujeito deve enfrentar". } \\
\text { (p.75) }\end{array}$ \\
\hline Chuva torrencial & "muita pressão, situação muito estressante". (p.75) \\
\hline Chuva escassa & $\begin{array}{l}\text { "pessoa que se sente com possibilidades de defender-se frente } \\
\text { às pressões ambientais" (p. 75) }\end{array}$ \\
\hline Gotas como lágrimas & "Angústia" (p. 75) \\
\hline Ausência de chuva & $\begin{array}{l}\text { "Oposicionismo, pessoa manipuladora. Tendência a negar as } \\
\text { pressões - conflitos- do meio". (p. 76) }\end{array}$ \\
\hline Raios & "Pressão que abala o sujeito" (p.76) \\
\hline
\end{tabular}




\section{ANEXO C}

\section{Principais categorias e representações do guarda chuva no Teste do Desenho da Pessoa na Chuva (QUEROL; PAZ, 1997)}

\begin{tabular}{|c|c|}
\hline Representação & Interpretação \\
\hline $\begin{array}{l}\text { Guarda chuva cobrindo } \\
\text { adequadamente a } \\
\text { pessoa }\end{array}$ & $\begin{array}{l}\text { “... sentimento de adequação, confiança em si mesmo, } \\
\text { segurança. Saber afrontar problemas sem expor-se a } \\
\text { riscos desnecessários, capacidade de prever" (p. 83) }\end{array}$ \\
\hline $\begin{array}{l}\text { Guarda chuva muito } \\
\text { grande em relação à } \\
\text { pessoa }\end{array}$ & "excessiva proteção e defesa" (p.83) \\
\hline $\begin{array}{l}\text { Guarda chuva muito } \\
\text { pequeno em relação à } \\
\text { pessoa }\end{array}$ & $\begin{array}{l}\text { "Defesas instáveis. Deixa a pessoa quase exposta às } \\
\text { pressões do meio". (p.84) }\end{array}$ \\
\hline Guarda Chuva fechado & $\begin{array}{l}\text { "resignação. Baixar a guarda, deixar que o outro o } \\
\text { defenda, que tome o seu lugar na defesa. Sem forças } \\
\text { para lutar" (p.84) }\end{array}$ \\
\hline $\begin{array}{l}\text { Guarda chuva fechado e } \\
\text { no chão }\end{array}$ & $\begin{array}{l}\text { "... sente que conta com pouca energia para se defender... } \\
\text { que segurar o guarda chuva é esforço excessivo" (p.86) }\end{array}$ \\
\hline Guarda chuva voando & "defesa instável". Ego muito frágil. Preocupações. (p.87) \\
\hline
\end{tabular}




\title{
ANEXO D
}

\section{Indicadores de vitimização encontrados por Agosta, Colombo e Barilari (2001/2006) no teste do Desenho da Pessoa na Chuva}

\author{
Indicadores (p. 19) \\ Interpretação (p. 31) \\ Uso do duplo \\ "Dissociação." \\ Ausência de mãos \\ "Timidez, inadequação e culpa. Falta de recursos para agir \\ na realidade. Dificuldades na comunicação." \\ Ausência de guarda-chuva "Falta de defesa." \\ Chuva Setorizada \\ "Situação de pressão". \\ Nuvens espessas e raios "Tendências auto-agressivas e doenças psicossomáticas." \\ sobre a cabeça* \\ Ausência de pés \\ “Desalento, abatimento, falta de ilusão. 'É o que não chega \\ nunca"”. \\ Cabeça deteriorada* \\ "Preocupação excessiva com a atividade mental e \\ Rigidez corporal \\ rendimento intelectual. Ideias obsessivas." \\ "Sensação de estar preso, isola-se para proteger-se do \\ mundo. Despersonalização. Desadaptação. Falta de \\ liberdade." \\ Rigidez no traço \\ "Incapacidade de usar defesas adequadas e eficazes". \\ Pobreza de detalhes \\ "Pobreza de recursos internos, falta de estimulação do meio." \\ Dimensão pequena \\ "Desvalorização, sentimentos de inadequação, retraimento, \\ sensação de clausura, percepção inadequada de si mesmo. \\ Preocupação com as relações com o ambiente."
}

* Estes itens não foram estatisticamente relevantes, mas as autoras consideram sua presença muito significativa a partir do ponto de vista clínico (AGOSTA; COLOMBO; BARILARI, 2001/2006) 


\section{ANEXO E}

\section{Fábulas de Düss}

\section{1 - FÁBULA DO PÁSSARO}

Um papai e uma mamãe pássaros e seu filhinho pequeno dormem no ninho, sobre um ramo. Mas, de repente começa um vento forte, a árvore se move e o ninho cai na terra. Os três pássaros acordam bruscamente. O papai voa imediatamente até um arbusto (ou árvore) e a mamãe até outro. O que fará o passarinho pequeno? Ele já sabe voar um pouco.

\section{2 - FÁBULA DO ANIVERSÁRIO DE CASAMENTO}

É o aniversário de casamento do papai e da mamãe. Eles se gostam muito e fizeram uma grande festa. Durante a festa a criação se levanta e vai sozinho até o fundo do jardim. Por quê?

\section{3 - FÁBULA DO CARNEIRINHO}

Uma mamãe ovelha e seu pequeno carneirinho estão num campo. O carneirinho brinca todo o dia perto da mamãe. Todas as tardes a mamãe Ihe dá um leite quente e bom, que ele gosta muito, mas já come grama. Um dia levaram para a mamãe ovelha outro carneirinho muito pequeno, que tem fome, para que a ovelha lhe dê leite. Mas a mamãe ovelha não tem leite suficiente para os dois e diz a seu filho: "Não tenho bastante leite para os dois, você vai comer grama fresca". O que fará o carneiro?

\section{4 - FÁBULA DO ENTERRO OU VIAGEM}

Um enterro passa por uma rua do bairro, e as pessoas perguntam: "Quem morreu? Do que morreu?" Respondem: "É alguém da família que mora naquela casa". "Quem é"?

\section{5 - FÁBULA DO MEDO}


Uma criança diz em voz baixa: "Puxa, que medo eu tenho!". Do que tem medo?

\section{6 - FÁBULA DO ELEFANTE}

Um menino tem um elefante pequeno do qual ele gosta muito; é muito bonito e tem uma tromba bem comprida. Um dia ao voltar de um passeio, o menino entra em seu quarto e percebe que o elefante mudou muito. O que mudou? Por que mudou?

\section{7 - FÁBULA DO OBJETO FABRICADO}

Uma criança conseguiu construir uma torre de barro que Ihe pareceu muito, muito bonita. O que fará? Sua mãe pede a ela que Ihe dê, mas não a obriga a fazer; a criança é livre para dar ou não à mãe. O que fará?

\section{8 - FÁBULA DO PASSEIO COM O PAI /OU A MÃE}

Um menino (ou menina) deu um passeio agradável pelo bosque com sua mãe, só os dois (ou com o papai, se for menina). Ficaram muito bem juntos. Quando voltaram para casa, o menino percebe que o papai não tem a cara de sempre. Por quê? (para menina: quando voltaram para casa, a menina percebe que a mamãe não tem a cara de sempre. Por quê?)

\section{9 - FÁBULA DA NOTÍCIA}

Uma criança volta da escola (ou passeio) e sua mamãe lhe diz: Não comece a fazer sua lição agora, tenho que dar a você uma notícia. O que a mamãe vai Ihe dizer?

\section{0 - FÁBULA DO SONHO MAU}

Uma criança acorda de manhã muito cansada e diz: "Que sonho ruim eu tive! "O que sonhou?" 


\section{ANEXO F}

Frases e instruções para aplicação - IFVD

Autoras: Agosta, C. Colombo, R. Barilari, Z. (2000-2005)

Adaptação no Brasil: Leila Tardivo, Antonio Augusto Pinto Junior (2010)

Instrucões: Vou ler para você algumas frases para que me responda:

SIM: quando sentir que acontece com você na maioria das vezes.

NÃO: quando sentir que não acontece com você na maioria das vezes

\begin{tabular}{|l|l|l|l|}
\hline \multicolumn{1}{|c|}{ FRASES } & SIM & NÃo & OBSERVAÇÕES \\
\hline 1. Na escola vou tão bem quanto antes & & & \\
\hline 2. A televisão me aborrece & & & \\
\hline 3. Tenho muito medo da noite & & & \\
\hline 4. Meus amigos sabem tudo a meu respeito & & & \\
\hline 5. Tenho dificuldade de ficar quieto & & & \\
\hline 6. Sou aquele/a que faz as tarefas da casa & & & \\
\hline $\begin{array}{l}\text { 7. Muitas vezes tenho vontade de pegar algo que não é } \\
\text { meu }\end{array}$ & & & \\
\hline 8. Quando fico zangado não consigo pensar & & & \\
\hline $\begin{array}{l}\text { 9. Me colocam de castigo quando bato nos meus } \\
\text { colegas }\end{array}$ & & & \\
\hline 10. Estou triste porque tudo dá errado comigo & & & \\
\hline $\begin{array}{l}\text { 11. Fico muito zangado quando me dizem "não" } \\
\text { 12. Acredito que o meu pai (*) não vai me machucar }\end{array}$ & & & \\
\hline
\end{tabular}




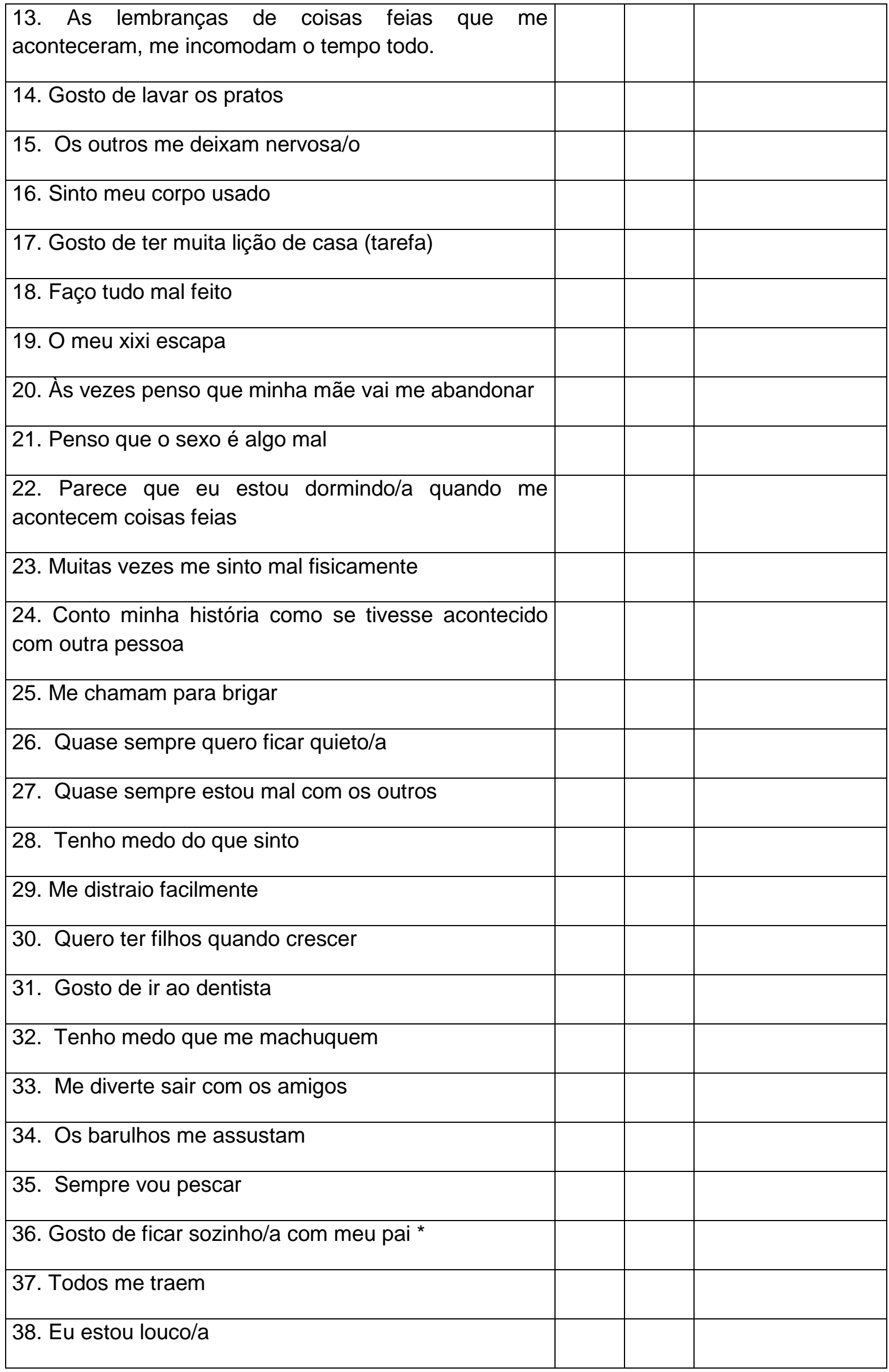




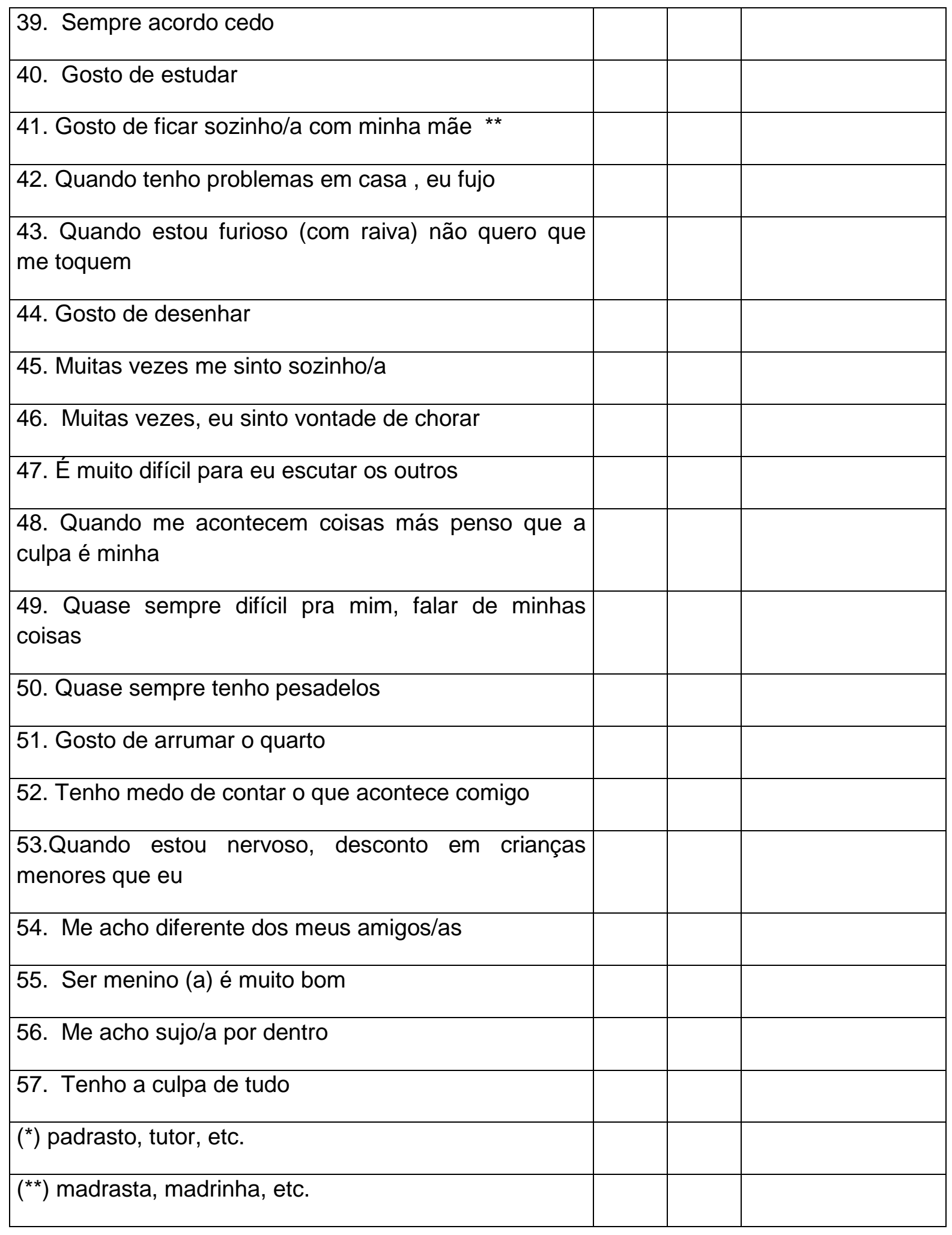




\section{ANEXO G}

\section{CRIVO DE CORREÇÃO DO IFVD}

Autoras: Agosta, C. Colombo, R. Barilari, Z. (2000-2005)

Adaptação no Brasil: Leila Tardivo, Antonio Augusto Pinto Junior (2010).

\begin{tabular}{|c|c|c|c|}
\hline FRASES & SIM & NÃO & TRANSTORNOS \\
\hline $1 \mathrm{Na}$ escola vou tão bem quanto antes & & $\mathrm{X}$ & COGNITIVO \\
\hline $2 \mathrm{~A}$ televisão me aborrece & 0 & 0 & FRASE NULA \\
\hline 3 Tenho muito medo da noite & $\mathrm{X}$ & & EMOCIONAL \\
\hline 4 Meus amigos sabem tudo a meu respeito & & $\mathrm{X}$ & SOCIAL \\
\hline 5 Tenho dificuldade de ficar quieto & $\mathrm{X}$ & & COMPORTAMENTAL \\
\hline 6 Sou aquele/a que faz as tarefas da casa & $\mathrm{X}$ & & SOCIAL \\
\hline $\begin{array}{l}7 \text { Muitas vezes tenho vontade de pegar algo que não é } \\
\text { meu }\end{array}$ & $\mathrm{X}$ & & COMPORTAMENTAL \\
\hline 8 Quando fico zangado não consigo pensar & $\mathrm{X}$ & & COMPORTAMENTAL \\
\hline 9 Me colocam de castigo quando bato nos meus colegas & $\mathrm{X}$ & & COMPORTAMENTAL \\
\hline 10 Estou triste porque tudo dá errado comigo & $\mathrm{X}$ & & EMOCIONAL \\
\hline 11 Fico muito zangado quando me dizem "não" & $\mathrm{X}$ & & COMPORTAMENTAL \\
\hline 12 Acredito que o meu pai (*) não vai me machucar & & $\mathrm{X}$ & EMOCIONAL \\
\hline $\begin{array}{l}13 \text { O tempo todo me incomodam as lembranças de coisas } \\
\text { feias que me aconteceram }\end{array}$ & $\mathrm{X}$ & & COGNITIVO \\
\hline 14 Gosto de lavar os pratos & 0 & 0 & FRASE NULA \\
\hline 15 Os outros me deixam nervosa/o & $\mathrm{X}$ & & COMPORTAMENTAL \\
\hline 16 Sinto meu corpo usado & $\mathrm{X}$ & & SOCIAL \\
\hline 17 Gosto de ter muita lição & 0 & 0 & FRASE NULA \\
\hline 18 Faço tudo mal feito & $\mathrm{X}$ & & EMOCIONAL \\
\hline 19 O meu xixi escapa & $\mathrm{X}$ & & FÍSICO \\
\hline 20 Às vezes penso que minha mãe vai me abandonar & $\mathrm{X}$ & 0 & EMOCIONAL \\
\hline
\end{tabular}




\begin{tabular}{|c|c|c|c|}
\hline 21 Penso que o sexo é algo mal & $\mathrm{X}$ & & COGNITIVO \\
\hline $\begin{array}{l}22 \text { Parece que eu estou dormindo/a quando me acontecem } \\
\text { coisas feias }\end{array}$ & $\mathrm{X}$ & & COGNITIVO \\
\hline 23 Muitas vezes me sinto mal fisicamente & $\mathrm{X}$ & & FÍSICO \\
\hline $\begin{array}{l}24 \text { Conto minha história como se tivesse acontecido com } \\
\text { outra pessoa }\end{array}$ & $\mathrm{X}$ & & EMOCIONAL \\
\hline 25 Me chamam para brigar & $\mathrm{X}$ & & COMPORTAMENTAL \\
\hline 26 Quase sempre quero estar quieto/a & $\mathrm{X}$ & & COMPORTAMENTAL \\
\hline 27 Quase sempre estou mal com os outros & $\mathrm{X}$ & & SOCIAL \\
\hline 28 Tenho medo do que sinto & $\mathrm{X}$ & & EMOCIONAL \\
\hline 29 Me distraio facilmente & $\mathrm{X}$ & & COGNITIVO \\
\hline 30 Quero Ter filhos quando crescer & & $\mathrm{X}$ & SOCIAL \\
\hline 31 Gosto de ir ao dentista & 0 & 0 & FRASE NULA \\
\hline 32 Tenho medo que me machuquem & $\mathrm{X}$ & & EMOCIONAL \\
\hline 33 Me diverte sair com os amigos & 0 & 0 & FRASE NULA \\
\hline 34 Os barulhos me assustam & $\mathrm{X}$ & & EMOCIONAL \\
\hline 35 Sempre vou pescar & 0 & 0 & FRASE NULA \\
\hline 36 Gosto de ficar sozinho/a com meu pai $\left(^{*}\right)$ & & $\mathrm{X}$ & EMOCIONAL \\
\hline 37 Todos me traem & $\mathrm{X}$ & & COGNITIVO \\
\hline 38 Eu estou louco/a & $\mathrm{X}$ & & COGNITIVO \\
\hline 39 Sempre acordo cedo & 0 & 0 & FRASE NULA \\
\hline 40 Gosto de estudar & 0 & 0 & FRASE NULA \\
\hline 41. Gosto de ficar sozinho/a com minha mãe ** & & $\mathrm{X}$ & EMOCIONAL \\
\hline 42 Quando tenho problemas em casa, eu fujo & $\mathrm{X}$ & & COMPORTAMENTAL \\
\hline 43 Quando estou furioso não quero que me toquem & $\mathrm{X}$ & & COMPORTAMENTAL \\
\hline 44 Gosto de desenhar & 0 & 0 & FRASE NULA \\
\hline 45 Muitas vezes me sinto só & $\mathrm{X}$ & & EMOCIONAL \\
\hline 46 Muitas vezes sinto vontade de chorar & $\mathrm{X}$ & & EMOCIONAL \\
\hline 47 É muito difícil para mim escutar os outros & $\mathrm{X}$ & & COGNITIVO \\
\hline 48 Quando me acontecem coisas más penso que & $\mathrm{X}$ & & EMOCIONAL \\
\hline
\end{tabular}




\begin{tabular}{|c|c|c|c|}
\hline minha & & & \\
\hline 49 Quase sempre me é difícil falar de minhas coisas & $\mathrm{X}$ & & COMPORTAMENTAL \\
\hline 50 Quase sempre tenho pesadelos & $\mathrm{X}$ & & EMOCIONAL \\
\hline 51 Gosto de arrumar o quarto & 0 & 0 & FRASE NULA \\
\hline 52 Tenho medo de contar o que me sucede & $\mathrm{X}$ & & EMOCIONAL \\
\hline $\begin{array}{l}53 \text { - Quando estou nervoso, desconto em crianças } \\
\text { menores que eu }\end{array}$ & $\mathrm{X}$ & & COMPORTAMENTAL \\
\hline $54 \mathrm{Me}$ acho diferente dos meus amigos/as & $\mathrm{X}$ & & SOCIAL \\
\hline 55 Ser menino (a) é muito bom & & $\mathrm{X}$ & GOGNITIVO \\
\hline $56 \mathrm{Me}$ acho sujo/a por dentro & $\mathrm{X}$ & & EMOCIONAL \\
\hline 57 Tenho a culpa de tudo & $\mathrm{X}$ & & EMOCIONAL \\
\hline$\left(^{*}\right)$ padrasto, tutor, etc. & & & \\
\hline$\left({ }^{* *}\right)\left({ }^{* *}\right)$ madrasta, madrinha, etc. & & & \\
\hline
\end{tabular}




\section{ANEXO H}

\section{QUESTIONÁRIO DE DEPRESSÃO INFANTIL}

Nome:

Data de nascimento: Idade (anos e meses) Sexo:

Série (escolaridade):

Responsável pela aplicação: Data de hoje:

\begin{tabular}{|c|c|}
\hline $\begin{array}{l}\text { 1. () ) Eu fico triste de vez em quando } \\
\text { ( ) Eu fico triste muitas vezes } \\
\text { ( ) Eu estou sempre triste }\end{array}$ & $\begin{array}{l}\text { 9. ( ) Eu não penso em me matar } \\
\text { ( ) Eu penso em me matar, mas não o faria } \\
\text { ( ) Eu quero me matar }\end{array}$ \\
\hline $\begin{array}{l}\text { 2. ( ) Para mim tudo se resolverá bem } \\
\text { ( ) Eu não tenho certeza se as coisas darão certo } \\
\text { para mim } \\
\text { ( ) Nada vai dar certo para mim }\end{array}$ & $\begin{array}{l}\text { 10. () Eu sinto vontade de chorar esporadicamente } \\
\text { () Eu sinto vontade de chorar frequentemente } \\
\text { () Eu sinto vontade de chorar diariamente }\end{array}$ \\
\hline $\begin{array}{l}\text { 3. ( ) Eu faço bem a maioria das coisas } \\
\text { () Eu faço errado a maioria das coisas } \\
\text { ( ) Eu faço tudo errado }\end{array}$ & $\begin{array}{l}\text { 11. () Eu me sinto entediado esporadicamente } \\
\text { () Eu me sinto entediado frequentemente } \\
\text { () Eu me sinto sempre entediado }\end{array}$ \\
\hline $\begin{array}{l}\text { 4. ( ) Eu me divirto com muitas coisas } \\
\text { () Eu me divirto com algumas coisas } \\
\text { () Nada é divertido para mim }\end{array}$ & $\begin{array}{l}\text { 12. ( ) Eu gosto de estar com as pessoas } \\
\text { ( ) Frequentemente eu não gosto de estar com } \\
\text { as pessoas } \\
\text { ( ) Eu não gosto de estar com as pessoa }\end{array}$ \\
\hline $\begin{array}{l}\text { 5. ( ) Eu sou mau de vez em quando } \\
\text { ( ) Eu sou mau com frequência } \\
\text { ( ) Eu sou sempre mau }\end{array}$ & $\begin{array}{l}\text { 13. () Eu tomo decisões facilmente } \\
\text { () É difícil para mim tomar decisões } \\
\text { () Eu não consigo tomar decisões }\end{array}$ \\
\hline $\begin{array}{l}\text { 6. ( ) De vez em quando eu penso que coisas ruins } \\
\text { vão me acontecer } \\
\text { ( ) Eu tenho medo que coisas ruins me aconteçam } \\
\text { ( ) Eu tenho certeza de que coisas terríveis me } \\
\text { acontecerão }\end{array}$ & $\begin{array}{l}\text { 14. ( ) Eu tenho boa aparência } \\
\text { ( ) Minha aparência tem alguns aspectos } \\
\text { negativos } \\
\text { ( ) Eu sou feio }\end{array}$ \\
\hline $\begin{array}{l}\text { 7. ( ) Eu gosto de mim mesmo } \\
\text { ( ) Eu não gosto de mim mesmo } \\
\text { () Eu me odeio }\end{array}$ & $\begin{array}{l}\text { 15. ( ) Fazer os deveres de casa não é um grande } \\
\text { problema para mim } \\
\text { ( ) Com frequência eu tenho que ser pressionado } \\
\text { para fazer os deveres de casa } \\
\text { ( ) Eu tenho que me obrigar a fazer os deveres de } \\
\text { casa }\end{array}$ \\
\hline $\begin{array}{l}\text { 8. ( ) Normalmente eu não me sinto culpado pelas } \\
\text { coisas ruins que acontecem } \\
\text { ( ) Muitas coisas ruins que acontecem são por minha } \\
\text { culpa } \\
\text { ( ) Tudo de mau que acontece é por minha culpa }\end{array}$ & $\begin{array}{l}\text { 16. ( ) Eu durmo bem à noite } \\
\text { ( ) Eu tenho dificuldades para dormir à noite } \\
\text { frequentemente } \\
\text { ( )Eu sempre tenho dificuldades para dormir à } \\
\text { noite }\end{array}$ \\
\hline
\end{tabular}




\begin{tabular}{|c|c|}
\hline $\begin{array}{l}\text { 17. ( ) Eu me canso de vez em quando } \\
\text { ( ) Eu me canso frequentemente } \\
\text { ( ) Eu estou sempre cansado }\end{array}$ & \\
\hline $\begin{array}{l}\text { 18. ( ) Alguns dias eu não tenho vontade de comer } \\
\text { ( ) Quase sempre eu não tenho vontade de comer } \\
\text { ( ) Eu nunca tenho vontade de comer }\end{array}$ & $\begin{array}{l}\text { 23. ( ) Meus trabalhos na escola são bons } \\
\text { ( ) Meus trabalhos na escola não são tão bons } \\
\text { quanto eram antes } \\
\text { ( ) Eu tenho me saído mal nas matérias em que } \\
\text { eu costumava ser bom }\end{array}$ \\
\hline $\begin{array}{l}\text { 19. ( ) Eu não temo sentir dor } \\
\text { ( ) Eu temo sentir dor com frequência } \\
\text { () Eu estou sempre temeroso de sentir dor }\end{array}$ & $\begin{array}{l}\text { 24. ( ) Meu nível é tão bom quanto o das outras } \\
\text { crianças } \\
\text { ( ) Meu nível pode ser tão bom quanto o das } \\
\text { outras crianças, se eu quiser } \\
\text { ( ) Meu nível nunca é tão bom quanto o das } \\
\text { outras crianças }\end{array}$ \\
\hline $\begin{array}{l}\text { 20. ( ) Eu não me sinto sozinho } \\
\text { () Eu me sinto sozinho com frequência } \\
\text { () Eu sempre me sinto sozinho }\end{array}$ & $\begin{array}{l}\text { 25. ( ) Eu tenho certeza que sou amado por alguém } \\
\text { ( ) Eu não tenho certeza se sou amado por } \\
\text { alguém } \\
\text { ( ) Ninguém gosta de mim realmente }\end{array}$ \\
\hline $\begin{array}{l}\text { 21. ( ) Eu me divirto na escola frequentemente } \\
\text { () Eu me divirto na escola de vez em quando } \\
\text { () Eu nunca me divirto na escola }\end{array}$ & $\begin{array}{l}\text { 26. ( ) Eu sempre faço o que me mandam } \\
\text { ( ) Eu faço o que me mandam com frequência } \\
\text { () Eu nunca faço o que me mandam }\end{array}$ \\
\hline $\begin{array}{l}\text { 22. ( ) Eu tenho muitos amigos } \\
\text { ( )Eu tenho muitos amigos mas gostaria de ter } \\
\text { ( ) Eu não tenho muitos amigos }\end{array}$ & $\begin{array}{l}\text { 27. ( ) Eu não me comunico bem com as pessoas } \\
\text { ( ) Eu me envolvo em brigas com frequência } \\
\text { ( ) Eu estou sempre me envolvendo em brigas. }\end{array}$ \\
\hline
\end{tabular}

TOTAL: 